\title{
Process Performance of the Pilot-Scale In Situ Vitrification of a Simulated Waste Disposal Site at the Oak Ridge National Laboratory
}

J. G. Carter

S. S. Koegler

S. O. Bates

June 1988

Prepared for the U.S. Department of Energy under Contract DE-AC06-76RLO 1830

Pacific Northwest Laboratory Operated for the U.S. Department of Energy by Battelle Memorial Institute 


\title{
DISCLAIMER
}

This repon was prepared as an account of work sponsored by an agency of the United States Government. Neither the United States Government nor any agency thereof, nor Battelle Memorial Institute, nor any or their employees, makes any warranty, expressed or implied, or assumes any legal liability or responsibility for the accuracy, completeness, or usefuiness of any information, apparatus, product, or process disclosed, or represents that its use would not infringe privately owned rights. Reference herein to any specific commercial product, process, or service by trade name, trademark, manufacturer, or otherwise does not necessarily constitute or imply its endorsement, recommendation, or favoring by the United States Government or any agency thereof, or Battelle Memorial Institute. The views and opinions of authors expressed herein do not necessarily state or reflect those of the United States Government or any agency thereof, or Battelle Memorial Institute.

\author{
PACIFIC NORTHWEST LABORATORY \\ operated by \\ BATTELLE MEMORIAL INSTITUTE \\ for the \\ UNITED STATES DEPARTMENT OF ENERGY \\ under Contract DE-ACO6-76RLO 1830
}

\begin{tabular}{|c|c|}
\hline \multirow{2}{*}{\multicolumn{2}{|c|}{ Printed in the United States of Americ $\exists$}} \\
\hline & \\
\hline $\begin{array}{l}\text { National Tech } \\
\text { United States }\end{array}$ & $\begin{array}{l}\text { tion Service } \\
\text { f Commerce }\end{array}$ \\
\hline 5285 & \\
\hline Spring $f$ & 22161 \\
\hline NT & \\
\hline & \\
\hline & \\
\hline & Price \\
\hline Pages & Codes \\
\hline $001-025$ & $\mathrm{~A} 02$ \\
\hline $026-050$ & $A 03$ \\
\hline $051-075$ & A04 \\
\hline $076-100$ & A05 \\
\hline $101-125$ & $A 06$ \\
\hline $126-150$ & A07 \\
\hline $151-175$ & $A 0 B$ \\
\hline $176-200$ & $\mathrm{AOS}$ \\
\hline $201-225$ & A010 \\
\hline $226-250$ & A011 \\
\hline $251-275$ & $\mathrm{~A} 012$ \\
\hline $276-300$ & $A 013$ \\
\hline
\end{tabular}


PNL -6530

UC -510

PROCESS PERFORMANCE OF THE PILOT-SCALE IN SITU VITRIFICATION OF A SIMULATED WASTE OISPOSAL SITE. AT THE OAK RIDGE NATIONAL LABORATORY
J. G. Carter
S. S. Koegler
S. 0. Bates

June 1988

Prepared for the U.S. Department of Energy under Contract DE-ACO6-76RLO 1830

Pacific Northwest Laboratory

Richland, Washington 99352 
.

$\boldsymbol{r}$ 
SUMMARY

Process feasibility studies have been successfully performed on three developmental scales to detemine the potential for applying in situ vitrification to intermediate-level (low-level) waste placed in seepage pits and trenches at Oak Ridge National Laboratory (ORNL). (a) In the laboratory, testing was performed in crucibles containing a mixture of 50\% ORNL soil and $50 \%$ limestone. In an engineering-scale test at Pacific Northwest Laboratory a 1/12-5cale simulation of an ORNL waste trench was constructed and vitrified, resulting in a waste product containing soil and limestone concentrations of 68 wts and 32 wt $\%$, respectively. In the pilot-scale test a 3/8-scale simulation of the same trench was constructed and vitrified at $0 \mathrm{RNL}$, resulting in soil and limestone concentrations of $80 \%$ and $20 \%$, respectively, in the waste product.

Results of the three scales of testing indicate that the ORNL intermediate-level (low-level) waste sites can be successfuliy processed by in situ vitrification; the waste form will retain significant quantities of the cesium and strontium. Because cesium-137 and strontium-90 are the major components of the radionuclide inventory in the ORNL seepage pits and trenches, final field process decontamination factors (i.e., losses to the off-gas system relative to the waste inventory) of $1.0 \mathrm{E}+4$ are desired to minimize activity buildup in the off-gas system. These values were realized during the engineering-scale tests for both cesium and strontium, but were 1.0 E+3 for cesium and 1.0 E+6 for strontium during pilot-scale processing. The vitrified material resulting from the engineering-scale tests effectively contained $99.99 \%$ of the cesium and strontium placed in the test site, with a $68 \%-50 i 1$ to $32 \%-1$ imestone ratio, while the pilot-scale test contained $99.90 \%$ cesium and 99.9999\% strontium with $80 \mathrm{wt} \%$ soil and $20 \mathrm{wt} \%$ limestone. Volume reduction (as measured by subsidence) for the engineering-scale test was $60 \%$ while the reduction for the pilot-scale test was $43 \%$. No migration of the cesium or strontium to the uncontaminated surrounding soil was detected in the engineering- or pilot-scale tests.

(a) Work performed under Contract DE-AC06-76RLO 1830 for the Department of Energy. 
The pilot-scale waste form consisted of a glass phase and a multicrystalline product. Both these phases had essentially the same elemental composition. The strontium and cesium in the monolith were found equally in both the glass and crystalline material and were generally uniformly distributed throughout the monolith. The durability of the waste form was evaluated by MCC-1, MCC-3, modified MCC-3, and Extraction Procedure toxicity tests. The durability of the waste form was similar to or better than that for two high-level nuclear waste glasses (i.e., PNL-76-78 and SRL-165). When compared to each other, waste forms resulting from the engineering- and pilot-scale tests were also found to be of similar durability.

These favorable results indicate that in situ vitrification can be used to treat the ORNL seepage pits and trenches. Vitrification of trench 7 would take approximately nine settings using a large-scale system and would produce a glass monolith of approximately $4.7 \mathrm{E}+7 \mathrm{~kg}$ (see calculations in Appendix A). Using glass decontamination factors of $99.90 \%$ for cesium-137 and $99.99 \%$ for strontium-90, the scrub solution would accumulate $0.3 \mathrm{Ci}$ of strontium-90 and $14.2 \mathrm{Ci}$ cesium-137 at each setting. Actual dose calculations must be made for these radionuclide inventories to determine exposures to personnel. Previously conducted research on cesium retention indicates that higher dolomite concentrations reduce operating temperatures and improve cesium retention, as shown in the engineering-scale test. This effect from higher dolomite concentrations in large-scale tests needs to be verified. 


\section{ACKNOWLEDGMENTS}

Pacific Northwest Laboratory (PNL) gratefully acknowledges Oak Ridge National Laboratory (ORNL) for providing the opportunity to perform this feasibility study. We especially appreciate the enthusiastic support of Brian Spalding, Gary Jacobs and Dave Farmer from ORNL's Environmental Sciences Division. We would like to thank PNL's operating staff of Craig Timmerman, Ken Oma, Jim Buelt, Ken Eliason, Tom Powe11, Mike Longaker, and Ton Hinkle.

Frank Hara and his respective staffs were invaluable in providing highquality laboratory studies and analytical services to the program. We would also like to acknowledge the material characterization staff of Gary Maupin, Anita Alger, and Mike Schweiger for their high-quality laboratory material evaluation of the vitrified mass product. In addition, we thank Xathy Borgeson for editing the text and DeDe Johnson for completing the word processing. 


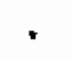




\section{CONTENTS}

SUMMARY ...........................

ACKNOWLEDGMENTS .....................

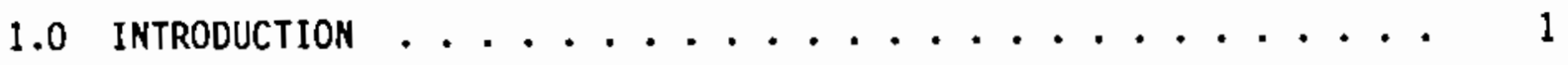

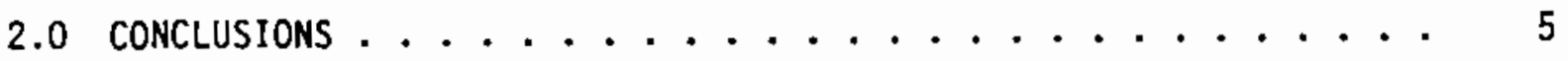

3.0 PROCESS DESCRIPTION ........................ 9

4.0 DESCRIPTION OF THE PILOT-SCALE SYSTEM . . . . . . . . 11

4.1 POWER DELIVERY SYSTEM . . . . . . . . . . . 11

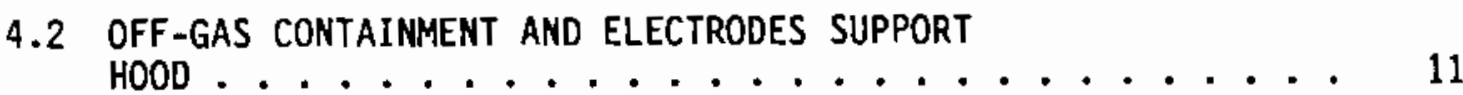

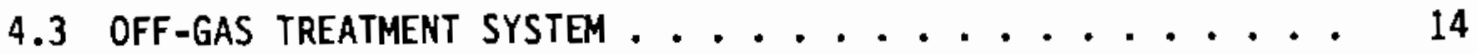

5.0 TEST DESCRIPTIONS . . . . . . . . . . . . . . . . 19

5.1 TEST PROCESS FOR ORNL ISV DEMONSTRATION $\ldots \ldots \ldots$

5.2 PROCESS EQUiPMENT EVALUATION AND PERFORMANCE . . . . . . 28

5.2.1 Electrical System ............. . 28

5.2 .2 Process off-Gas System ........... 32

5.3 MATERIAL CHARACTERIZATION STUdIES .......... 35

5.3.1 Product Characterization .......... 36

5.3.2 Chemical Durability of Product ......... 48

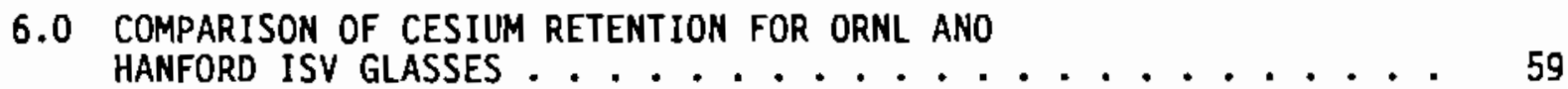

6.1 TECHMICAL APPROACH ...................... 59

6.2 test Evaluations ...................... 60

7.0 PILOT-SCALE TEST RESULTS AND ANALYSIS . . . . . . . . 63

7.1 GenERAL OBSERVATIONS ...................... 63

7.2 COMPARISON OF ENGINEERING- AND PILOT-SCALE TEST . . . . 65 


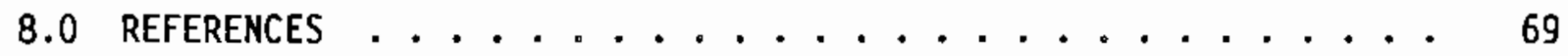

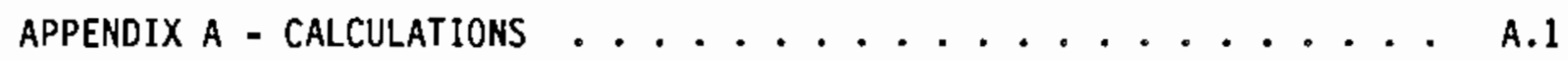
APPENDIX B - ANALYTICAL DATA FOR PROCESS SCRUB SOLUTIONS . . . . . B. 1

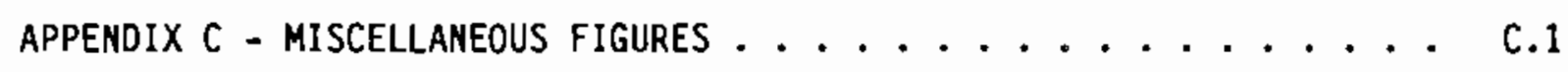
APPENDIX D - ANALYTICAL DATA FOR VITRIFIED MASS . . . . . . D.1 APPENDIX E - ANALYTICAL PROCEDURES ............. E. . . . 


\section{FIGURES}

1 Location of the Radioactive Liquid-Waste Disposal

Pits and Trenches at ORNL and the Pilot-Scale ISV

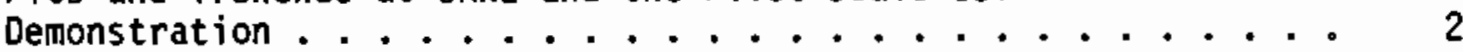

2 Construction Details of ORNL Liquid-Haste

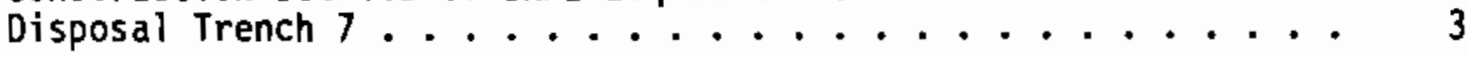

3 Operating Sequence of In Situ Vitrification System . . . . . 9

4 Cutaway View of the Pilot-Scale Process Trailer

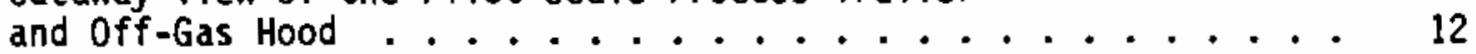

5 Scott-Tee Electrical Connection for the Pilot-Scale ISV System ..........................

6 Schematic Drawing of the Pilot-Scale ISV

Off-Gas Treatment Systen ................. 15

7 Tanden Nozzle Hydro-Sonic Scrubber . . . . . . . . . . 16

8 Pilot-Scale Test Site Prior to Site Preparation . . . . . . . 21

9 Central Cross Section of the Pilot-Scale ISV Demonstration Trench . . . . . . . . . . . . . 22

10 Predicted Shape of the Pilot-Scale ISV Mass ........... 23

11 Excavation of the 3/8-Scale Model of Trench 7 . . . . . . 24

12 View of Chemical and Crushed Limestone as Placed in the 3/8-scale Trench ............... 25

13 A-Phase and B-Phase Voltage Versus Run Time . . . . . . . . . 29

14 A-Phase and B-Phase Amperage Versus Run Time . . . . . . . . 29

15 Total Power Versus Run Time . . . . . . . . . . . . . . 30

16 Cumulative Energy Versus Run Time . . . . . . . . . . . 30

17 Temperature and Vitrified Mass Depth Versus Run Time ........................ 31

18 Total Cs Accumulation in Scrub Solution Versus Vitrified Mass Depth .................. 35

19 Distribution of $\mathrm{Cs}$ and $\mathrm{Sr}$ Released from Melt Zone . . . . . 36 
20 View of Vitrified Mass After Excavation and Sampling . . . . . 37

21 Relative Positions of Core Samples Taken from ORNL ISV Monolith ..................... 38

22 Position of Grab Samples Taken from the ISV

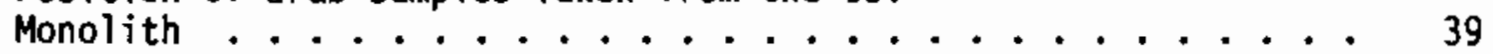

23 X-Ray Diffractometry Results of Gray Crystalline Material from Pilot-Scale ORNL ISV Test ............ 43

24 Typical Microstructure of Gray Crystalline Material from Pilot-Scale ORNL ISV Test . . . . . . . . . . . 44

25 EDAX Spectra of Phases A in Figure 24 . . . . . . . . . . 45

26 EDAX Spectra of Phases 8 in Figure 24 . . . . . . . . . 46

27 EDAX Spectra of Phases C in Figure 24 . . . . . . . . . . 46

28 X-Ray Cesium Mapping of Typical Microstructure of Gray Crystalline Material from Pilot-Scale ORNL ISV Test . . . . . . 47

29 Normalized Elemental Concentrations Versus (t•SA/V) for ORNL Pilot-Scale ISV Sample . . . . . . . . . . . 54

30 Average Normalized Elemental Concentrations Versus $(t \cdot S A / V)$ for ORNL Pilot-Scale ISV Sample $231 \ldots . . \ldots 4$

31 Normalized Elemental Concentrations Versus ( $t \cdot S A / V)$

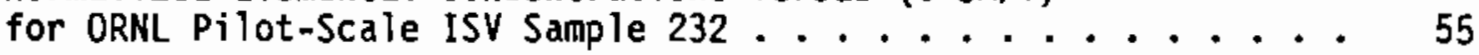

32 Normalized Elemental Concentrations Versus ( $t \cdot S A / V$ ) for ORNL Pilot-Scale ISV Sample 233 . . . . . . . . . . . 55

33 Nomalized Silicon Concentrations Versus ( $t \cdot S A / V$ ) for ORNL Pilot-Scale ISV Samples and ORNL EngineeringScale Sample ...................... . . 56

34 Comparison of $M C C-1$ Tests from Engineering-Scale Product to the Pilot-Scale Product 


\section{TABLES}

1 Scales of Testing Units for Developing Technology

2 Predicted and Actual Data Obtained from ISV/ORNL Pilot-Scale Test ................. 27

3 Particulate Accumulation in Scrub Solutions ......... 33

4 Location of Samples Chosen for Detailed Evaluation . . . . . 40

5 Oxide Compositions for ISV Pijot-Scale Test Samples . . . . . 40 40

6 Comparison of Normalized Release from MCC-1 Leach Testing for ORNL Pilot-Scale ISV Products and Some High-Level

Nuclear Waste Glasses ................. 50

7 Comparison of Average Normalized Release from MCC-3 Leach

Testing: $0.45-\mu \mathrm{m}$ Filtrate for ORNL Pilot-Scale ISV

Products and Some High-Leve] Nuclear Haste Glasses ....... 51

8 Comparison of Average Nomalized Releases from MCC-3 Leach

Testing: 18-Angstrom Filtrate for ORNL Pilot-Scale ISV

Products and Some High-Level Nuclear Haste Glasses ....... 52

9 Results from EP Toxicity Testing of the Pilot-Scale

ISV Test at ORNL ................... 57

10 Summary of Glass $\mathrm{Cs}$ and $\mathrm{Sr}$ Concentrations and 100 Poise Temperatures ............... 60

11 Analyzed Compositions of the Glasses Used in the Cesium Retention Study.............. 61

12 Summary of Cesium Off-Gas and Retention Results . . . . . . 61

13 Oxide Compositions for ORNL ISV Pilot- and

Engineering-Scale Tests ............... 64 
. , 


\subsection{INTRODUCTION}

Pacific Northwest Laboratory (PNL) has successfully performed laboratory, engineering-scale, and pilot-scale tests of the in situ vitrification (ISV) process on actual Oak Ridge National Laboratory (ORNL) soil and limestone. In situ vitrification is an emerging, in-ground thermal treatment technology that fixes radioactive contamination in the soil by converting it to a glass and crystalline waste form. The purpose for performing this test on the ORNL soil and limestone was to ascertain if ISV could be successfully applied to ORNL seepage pits and trenches.

ORNL used a series of seven seepage pits and trenches (Figure 1) between 1951 and 1966 for the disposal of approximately $2.5 \times \mathrm{E}+7$ gallons of liquid radioactive waste. Approximately $200,000 \mathrm{Ci}$ of ${ }^{90} \mathrm{Sr}$ and $600,000 \mathrm{Ci}$ of ${ }^{137} \mathrm{Cs}$, (Spalding 1987) along with smaller quantities of other fission products, uranium, and transuranium elements, were disposed in this series of pits and trenches. To facilitate the seepage of liquids the trenches were constructed on the tops of ridges, oriented perpendicular to the strike of the bedding of the formation, and filled with crushed limestone or dolomite (Figure 2). As the liquid seeped, the $C_{s}$ and $S r$ remained within, or in close proximity to, the trenches. Cesium is generally irreversibly sorbed by the illite-rich soils at ORNL. Strontium, on the other hand, is poorly sorbed. To reduce the mobility of $\mathrm{Sr}$, the pits and trenches were treated with highly alkaline solution $(\mathrm{NaOH})$ at the time of disposal. All of the pits and trenches are now covered with asphalt caps to reduce the direct flow of precipitation through the waste. Currently, the pits and trenches do not significantly contribute to surface water contamination, and most of the $\mathrm{Cs}_{s}$ and $\mathrm{Sr}$ remains in close proximity to the bottom of the pits and trenches. However, it will be necessary to apply either a long-term site maintenance and monitoring program or some form of remedial action so the sites can be permanently decommissioned. This need has evolved because of the large inventory of ${ }^{137} \mathrm{Cs}$ and ${ }^{90} \mathrm{Sr}$, the close proximity of the waste to the surface, and the potential for significant release in the future.

PNL began development of the ISV technology in 1980 under contract to the U.S. Department of Energy (DOE) (Brouns, Buelt, and Bonner 1983). Since 


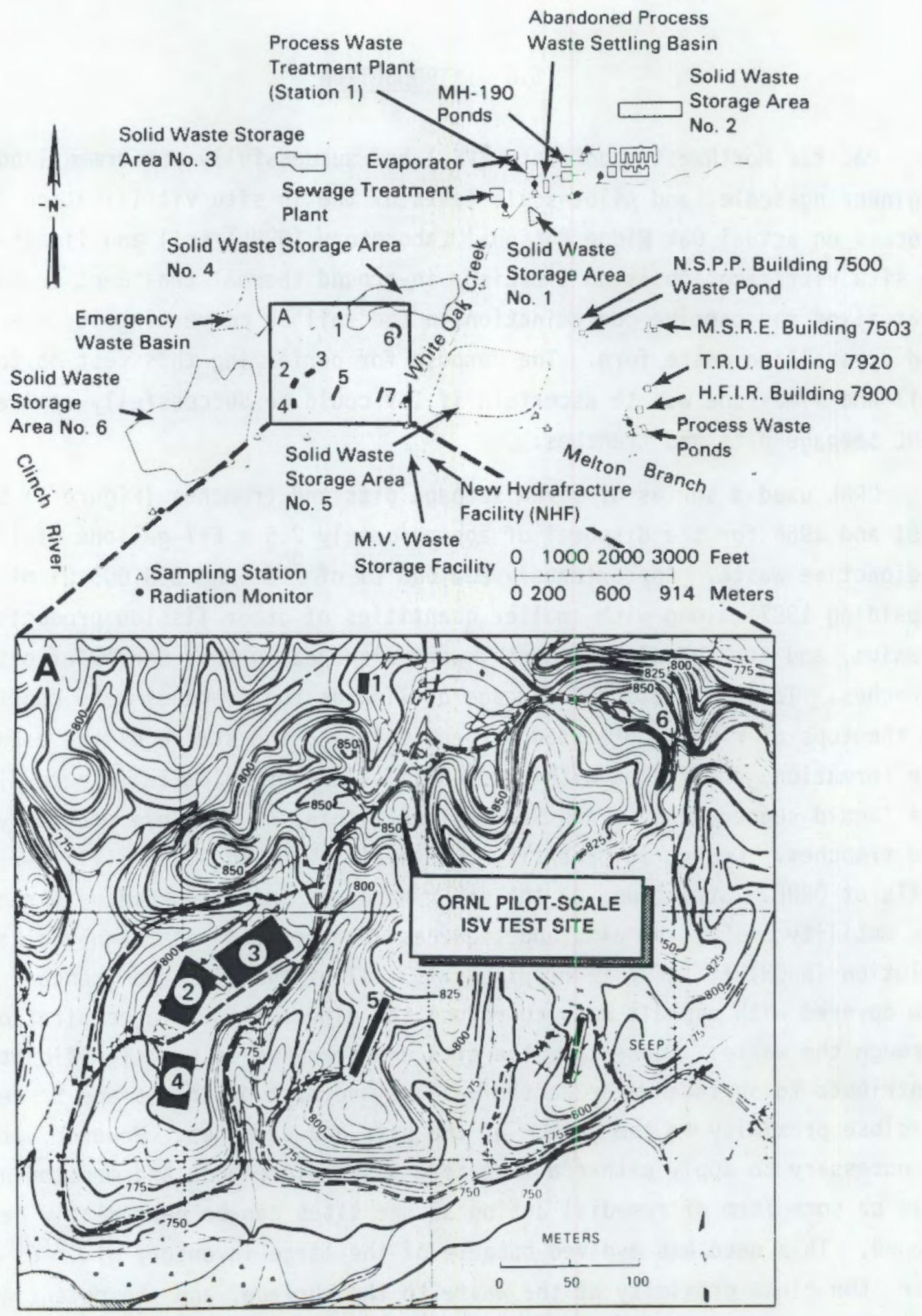

FIGURE 1. Location of the Radioactive Liquid-Waste Disposal Pits and Trenches at ORNL and the Pilot-Scale ISV Demonstration (from Spalding 1987) 


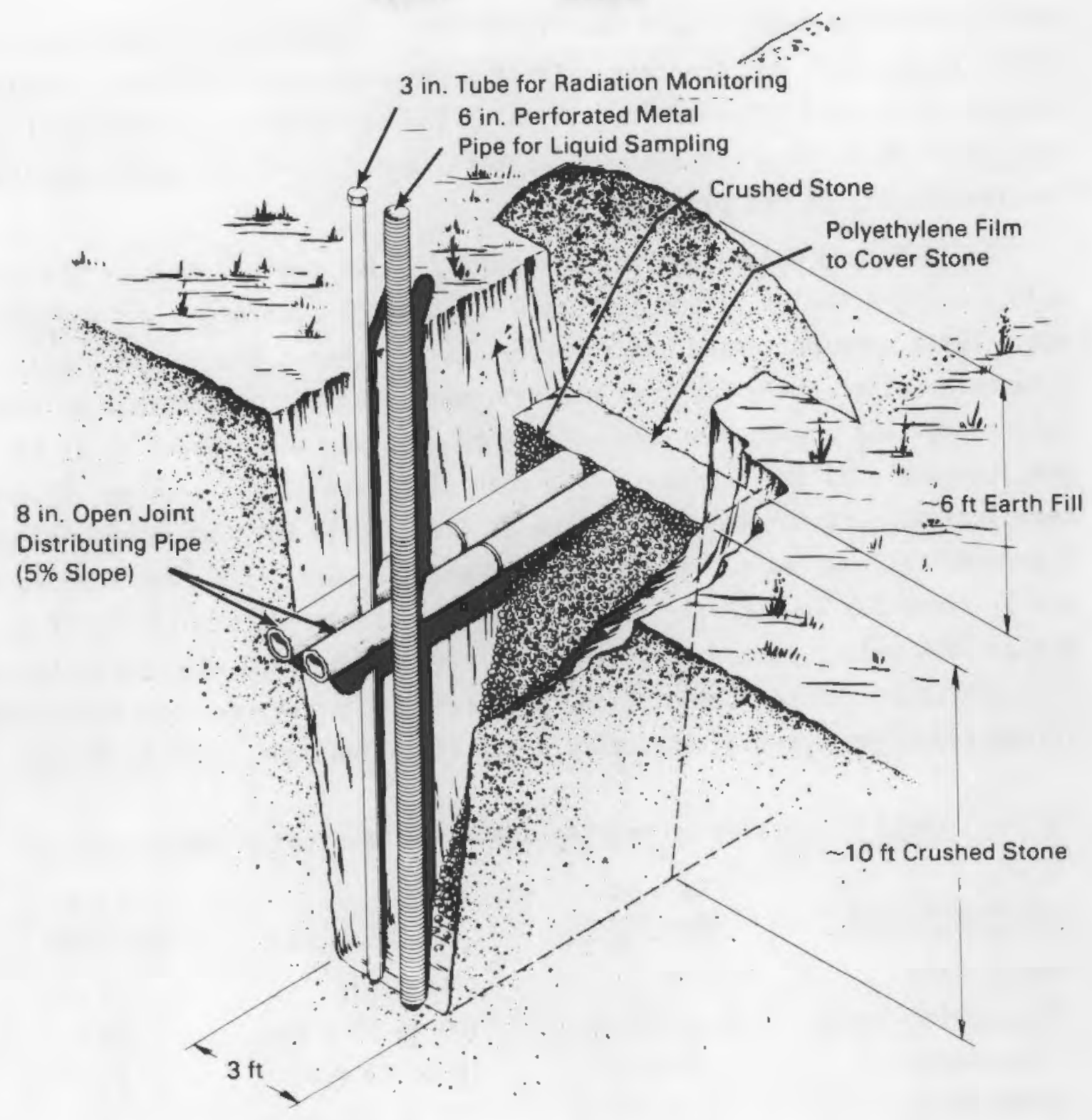

FIGURE 2. Construction Details of ORNL Liquid-Waste Disposal Trench 7 (Spalding 1987)

that time numerous experimental tests using a variety of conditions and waste types have been conducted (Buelt et al. 1987; Timmerman and Oma 1984;

Timmerman et al. 1983). A large-scale ISV unit was designed, fabricated, and tested (Buelt and Carter 1986). The large-scale unit was designed for processing transuranic-contaminated soil, but the design is adaptable to a 
variety of waste types (Buelt and Freim 1986), including Oak Ridge contaminated seepage pits and trenches. Table 1 describes the different scales of testing units that PNL used in developing ISV technology. The successful results of 52 bench-, engineering-, pilot-, and large-scale tests demonstrates the feasibility of the process.

In 1986, and under contract with ORNL, it was decided to test ISV technology using actual soil and limestone from ORNL. Laboratory and engineeringscale tests were performed and reported (Carter, Bates and Maupin 1987). A 3/8-scale, pilot-scale ISV test was designed based on the findings of the laboratory- and engineering-scale tests to simulate the processing of the ORNL seepage pits and trenches. The main objective of the test was to provide technical support for the application of large-scale ISV technology to ORNL intermediate-level waste in seepage pits and trenches. The test evaluated Cs and $\mathrm{Sr}$ retention in the vitrified soil and limestone representative of an actual ORNL site. In addition, the vitrified product and ORNL soil//imestone were characterized for composition, physical properties, melting properties, volume reduction, crystal structure/devitrification, and chemical durability.

TABLE 1. Scales of Testing Units for Developing Technology

\begin{tabular}{|c|c|c|c|}
\hline Equipment Size & $\begin{array}{l}\text { Electrode } \\
\text { Separation }\end{array}$ & Block Size & $\begin{array}{c}\text { Test } \\
\text { Completed }(a)\end{array}$ \\
\hline Bench-Scale & 4 in. & 1 to $20 \mathrm{lb}$ & 7 \\
\hline Engineering-Scale & 9 to $15 \mathrm{in}$. & $100 \mathrm{lb}$ to 1 ton & 25 \\
\hline Pilot-Scale & 3 to $4 \mathrm{ft}$ & 10 to 50 tons & 15 \\
\hline Large-Scale & 11 to $18 \mathrm{ft}$ & 400 to 800 tons & 5 \\
\hline
\end{tabular}

(a) As of December 1987. 


\subsection{CONCLUSIONS}

In situ vitrification was successfully performed on a $3 / 8$-scale, simulated test site at ORNL. The test was performed to determine the technical feasibility for applying ISV technology to ORNL intermediate-level waste. Evaluation of the test results indicates that the ISV process is suitable for inmobilization of ORNL intermediate-level waste. In addition, analysis of the data from the $3 / 8$ pilot-scale test resulted in the following observations:

- The ISV process is technically feasible for this application, as confirmed by the performance of the process equipment and the evaluation of the ORNL soil, limestone, pilot-scale off-gas scrub system, off-gas high-efficiency particulate air (HEPA) filters, and core samples from the vitrified mass.

- Soil-to-off-gas decontamination factors (DFs), as determined by the pilot-scale testing, were $1.0 \mathrm{E}+3$ for $\mathrm{Cs}$ and $1.4 \mathrm{E}+6$ for $\mathrm{Sr}$. These factors are equivalent to a Cs retention of $99.90 \%$ and $\mathrm{Sr}$ retention of $99.9999 \%$ in the molten soil. Quantities of $C_{s}$ and $\mathrm{Sr}$ used in the pilot-scale test were several orders of magnitude higher than the mass of radioisotopes present in the ORNL trenches and seepage pits.

- Volume reductions of greater than $40 \%$ may be expected. Volume reduction was $60 \%$ for the engineering-scale test and $43 \%$ for the pilot-scale test, thus eliminating concerns for future subsidence.

- The soil-to-limestone ratio of the vitrified mass for the pilotscale test was estimated to be $80 \mathrm{wt} \%$ soil to $20 \mathrm{wt} \%$ limestone.

- A gray, spherical multi-phase crystalline product formed inside the vitrified mass in regions of slowest cooling (center of mass between the four electrodes). This product was found to be as durable as the vitrified glass product. 
- The normalized mass release and dissolution rates at $90^{\circ} \mathrm{C}$ as determined by MCC-1, MCC -3 , and modified MCC -3 testing of the vitrified mass samples are approximately equivalent to those for PNL 76-68 and SRL-165 high-level waste glasses. In addition, once the ISV vitrified product has cooled, the anticipated storage temperature would be essentially ambient ground temperature. At these temperatures dissolution rates could be as much as one or two orders of magnitude lower.

- The elemental compositions of the glass and multi-crystalline phases were essentially equal. This indicates that the resulting monolith was once a relatively homogeneous melt and the crystalline material formed from the glass during slow cooling.

- Semi-quantitative $x$-ray fluorescence (XRF) analysis indicated that the $\mathrm{Sr}$ was very uniformly distributed throughout the vitrified monolith. Distribution of Cs varied by as much as $50 \%$ in the cores, but Cs was generally uniformly dispersed throughout the monolith. Little variation in $C_{S}$ or $\mathrm{Sr}$ was observed vertically in any of the cores. The grab samples from the outer areas of the monolith contained the same levels of both $\mathrm{Cs}$ and $\mathrm{Sr}$ as did the core samples.

- The ISV process was not observed to induce migration of the Cs or $\mathrm{Sr}$ below the monolith into unreacted soil. However, some $\mathrm{Cs}_{\mathrm{s}}$ was observed in partially reacted soil near the edge of the melt. Whether the Cs enters the partially reacted material before, during, or after the test as a result of core drilling is not known.

- The crystalline material was identified as a mixture of pseudowollastonite $\left(\mathrm{CaO}-\mathrm{SiO}_{2}\right)$ and anorthite (a feldspar, $\mathrm{CaO}-\mathrm{Al}_{2} \mathrm{O}_{3}-\mathrm{SiO}_{2}$ ).

- Based on Extraction Procedure (EP) toxicity testing, the pilotscale waste form, both glass and crystalline phases, is not EP toxic. 
- The compositions of the waste forms in the pilot-scale test differed from that of the engineering-scale test, due to the much higher level of $\mathrm{MgO}$ in the "limestone" used in the engineeringscale test.

- The durability of the waste form from the engineering-scale ISV test was very similar to the durability of the waste form from the pilot-scale test, despite the difference in composition (the engineering-scale test revealed a higher $\mathrm{MgO}$ wt\%).

- Pilot-scale test DF's show processing system accumulation for a large-scale system of $0.3 \mathrm{Ci}$ of ${ }^{90} \mathrm{Sr}$ and $14.2 \mathrm{Ci}{ }^{137} \mathrm{Cs}$ at each setting. The additional research on Cs retention as reported in Section 6.0 indicates that although Cs volatility is directly proportional to viscosity, it is a much stronger function of temperature. Data indicate that reducing soil operation temperatures by a factor of 1.2 from $1650^{\circ} \mathrm{C}$ to $1325^{\circ} \mathrm{C}$, while adjusting the composition to hold viscosity constant, will reduce Cs volatility by a factor of 3 . More laboratory studies are recommended on how to better control Cs volatility by adjusting soil composition on ORNL soil. The effect of higher dolomite concentrations was demonstrated in the engineering-scale test for temperature reduction and higher Cs retention.

The laboratory-, engineering-, and pilot-scale tests indicate the potential for using ISV to treat the trenches and seepage pits at the ORNL contaminated waste sites. Based on the results of these feasibility tests, it appears that adequate technical bases are available to recommend proceeding with a large-scale demonstration on a trench at ORNL. 



\subsection{PROCESS DESCRIPTION}

The ISV process as applied to contaminated soil stabilization involves the insertion of electrodes into the soil, typically in a square array. A starter path for electrical current is established by using a small amount of a graphite and glass frit mixture placed between the electrodes on the soil surface. Dissipation of power through the starter material creates temperatures that are high enough to melt a layer of soil, thus establishing a molten, conductive path. This molten zone continues to grow downward and encompass the contaminated soil. Rocks (if present), which are less dense, can create a floating layer near the molten surface. The rocks are eventually incorporated into the molten mass.

Figure 3 illustrates the process sequence. At the high temperatures created (approximately $1300^{\circ} \mathrm{C}$ to $1600^{\circ} \mathrm{C}$ ), organic materials pyrolyze, diffuse to the surface, and combust. This movement of gas through the melt may produce some porosity near the surface of the melt. Any off-gases from the process are collected, treated, and monitored to ensure their environmentally safe release. Remaining ash, along with other noncombustible material, dissolves or becomes encapsulated in the molten soil. Natural convective currents within the molten soil help to uniformly distribute the stabilized

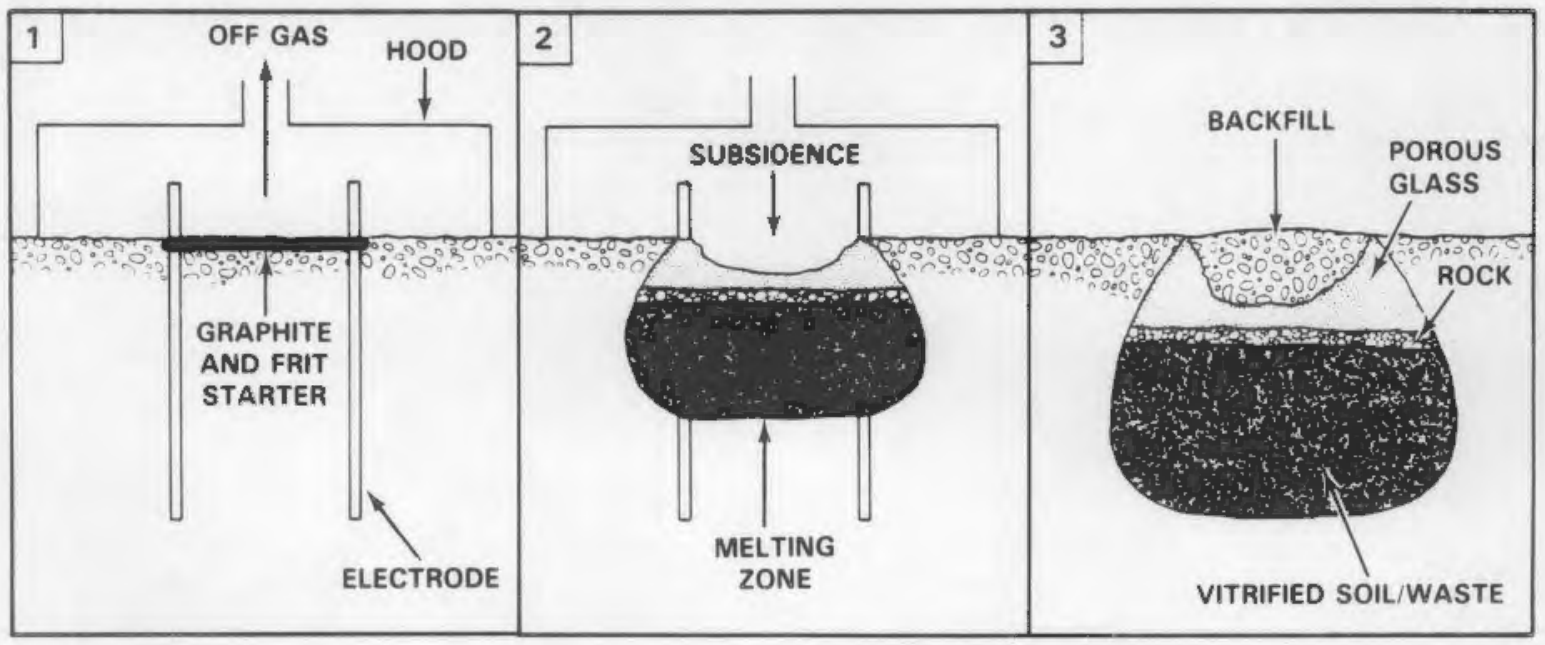

FIGURE 3. Operating Sequence of In Situ Vitrification System 
materials. The molten soil cools to a durable glass and crystalline waste form physically resembling natural obsidian.

The principles of the ISV operation are based on extensive joule-heated melter work performed at PNL for various nuclear immobilization projects (Buelt et al. 1979). The joule-heated principle operates by internal resistance heating of the conductive material as an electrical current passes through the molten media. In ISV, the resistance decreases as the molten mass grows. To maintain a power level high enough (according to the formula $\mathrm{P}=\mathrm{I}^{2} \mathrm{R}$ ) to continue melting more soil, the current must be increased. A power transformer with multiple voltage taps is used to provide the variable currents needed during ISV processing. As the melt progresses and resistance decreases, the lower voltage taps on the power transformer allow increased amperage to the melt, maintaining a high power level. The process will continue until heat losses from the melt approach the energy delivered to the molten soil via the electrodes, or until power is discontinued to the melt.

A hood over the vitrification zone is maintained under a slight negative pressure to contain any hazardous gases or particulates that may be released. The hood also provides support for the electrodes. The negative pressure on the hood is supplied by the off-gas treatment system, which scrubs and filters any potentially hazardous components from the off-gas stream. 


\subsection{DESCRIPTION OF THE PILOT-SCALE SYSTEM}

The pilot-scale test system at ORNL used four electrodes having a 1.2-m separation, and consisted of a power-control, gas-scrubbing unit and an offgas containment hood over the test site. A cutaway of the process trailer and off-gas hood is illustrated in Figure 4 . Prior to the ORNL test, this system had been used on pilot-scale tests at the Hanford site.

\subsection{POWER DELIVERY SYSTEM}

The pilot-scale power system uses a Scott-Tee connection to transform a three-phase input to a balanced two-phase secondary load using diagonally opposed electrodes in a square pattern (Figure 5 ). The $500-\mathrm{kW}$ power supply may be either voltage or current regulated. The alternating primary current is rated at $480 \mathrm{~V}, 600 \mathrm{~A}, 3$ phase, and $60 \mathrm{~Hz}$. The transformer has four separate voltage tap settings of $1000,650,430$, and $250 \mathrm{~V}$. Each voltage tap has a corresponding amperage rating of 250, 385, 580, and $1000 \mathrm{~A}$ per phase, respectively. The amount of three-phase input power delivered to the transformer is controlled by adjusting the conductive angle of the thyristor switches located in each of the three input lines. These switches, in conjunction with selectable taps on the transformer secondary, regulate the amount of power deliverable to both secondary phases. The Scott-Tee connection provides an even power distribution among the three primary phases when the molten zone approaches a uniform resistance load. During the test at ORNL, this power system proved effective in maintaining a balance load to the electrodes.

\subsection{OFF-GAS CONTAINMENT AND ELECTRODES SUPPORT HOOD}

The off-gas containment and electrode-support hood is constructed from seven panels of 20-gauge stainless steel bolted together. The hood is $3.1 \mathrm{~m}$ wide, $5.5 \mathrm{~m}$ long, and $0.9 \mathrm{~m}$ high. Four leveling supports are attached to the corners of the hood. The hood also has a port for viewing and providing access to the inside region of the hood. A central off-gas port allows direct coupling of the hood to the processing trailer and off-gas treatment 


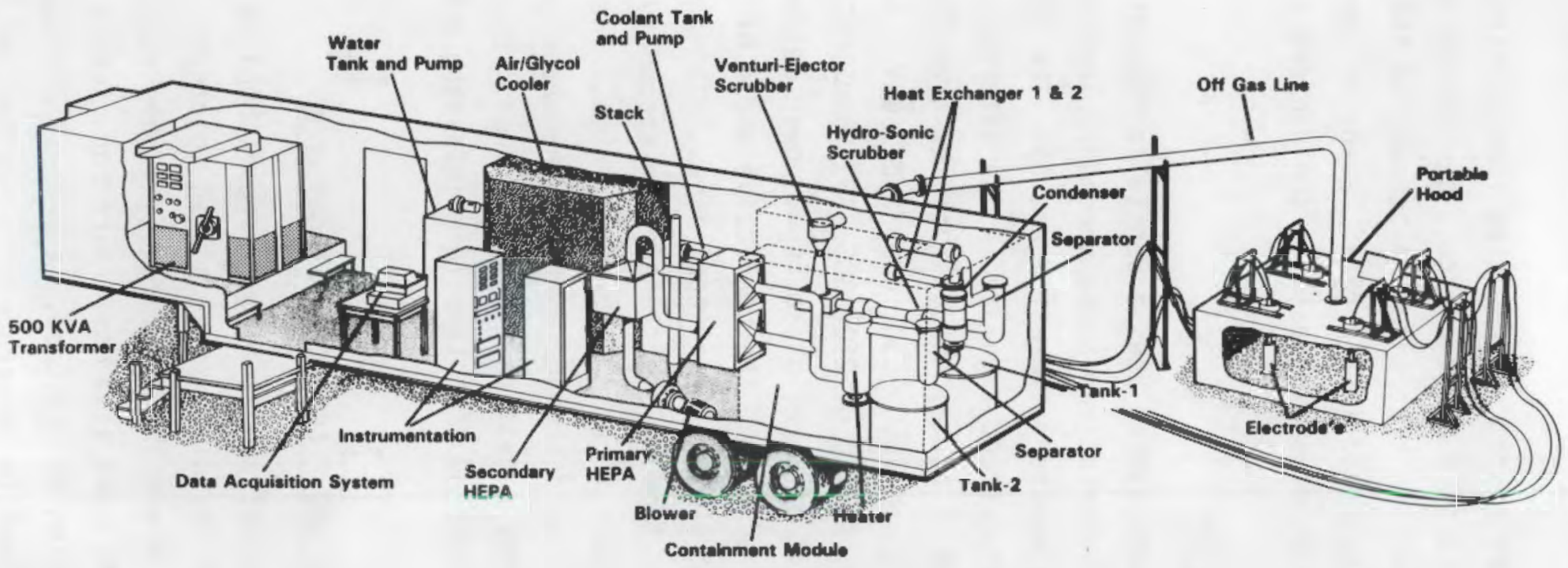

FIGURE 4. Cutaway View of the Pilot-Scale Process Trailer and Off-Gas Hood 


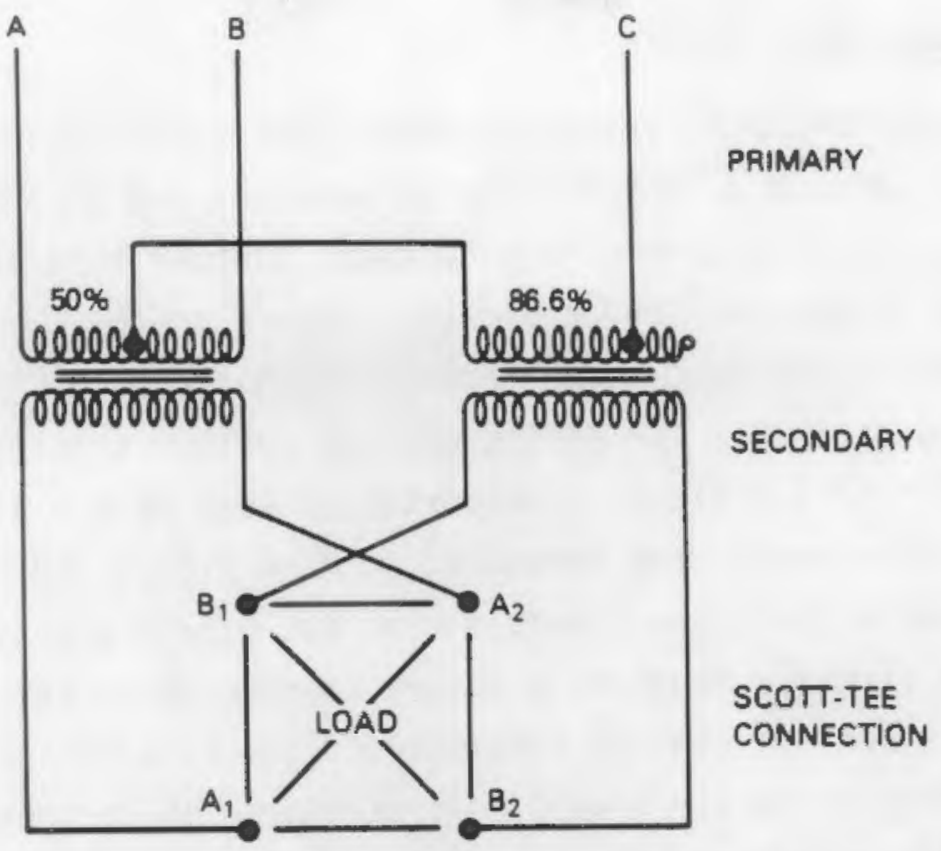

FIGURE 5. Scott-Tee Electrical Connection for the Pilot-Scale ISV System

system. The hood is equipped with heat fins installed on the surfaces of panels to help dissipate radiant heat transferred from the partially molten surface during processing. The hood, designed to withstand a water vacuum of $18 \mathrm{~cm}$, was sealed to the surface of the soil surrounding the molten zone by means of a flexible skirt of high-temperature-resistant, tightly woven fiber attached to the bottom of all side panels. The skirt extended approximately $0.6 \mathrm{~m}$ away from the hood to allow for a hood-to-ground seal when covered with a layer of soil. Electrical connections were made to the molybdenum electrodes protruding through the hood. The upper molybdenum electrodes were surrounded by electrically insulated sleeves that allowed adjustments of the electrode positions. The electrodes and busses were supported by insulators above the sleeves. The insulators were designed to withstand movement of the molten mass against the electrodes from convective currents and the gravitational and buoyant forces exerted on the electrodes. The electrodes consisted of $5.0-\mathrm{cm}$ molybdenum rods surrounded by a $0.15-\mathrm{m}$ graphite sleeve. The molybdenum rods were coated with a protective coating of $\mathrm{MoSi}_{2}$ to prevent oxidation. 


\subsection{OFF-GAS TREATMENT SYSTEM}

The off-gas treatment system is shown schematically in Figure 6 . The off-gas passes through a venturi-ejector scrubber and separator, a Hydrosonic (a) scrubber, a separator, a condenser, another separator, a heater, two stages of HEPA filtration, and a blower. Liquid to the two wet scrubbers is supplied by two independent scrub recirculation tanks, each equipped with a pump and heat exchanger. The entire off-gas system is installed in a 13.7-mlong semitrailer to facilitate transportation (see Figure 4). All of the off-gas components except the second-stage HEPA filter and blower are housed within a removable containment module that has gloved access and is maintained under a slightly negative pressure to protect workers from potential contamination. Heat is removed from the off-gas by a closed-loop cooling system consisting of an air/liquid heat exchanger, a coolant storage tank, and a pump. A 1:1 mixture of water and ethylene glycol is pumped first from the storage tank through the shell side of the condenser and the two scrubsolution heat exchangers, and then through the air/liquid exchanger, where heat is removed from the coolant.

The venturi-ejector scrubber serves both as a quencher and high-energy scrubber. The second scrubber is a two-stage Hydro-Sonic scrubber (tandem nozzle scrubber) as illustrated in Figure 7. The first section condenses vapors, removes large particles, and initiates growth of the finer particles so that they are easily captured in the second stage. Particles are captured when the gas is mixed with fine water droplets produced by spraying water into the exhaust of the subsonic nozzle. Mixing and droplet growth continues down the length of the mixing tube. Large droplets containing the particles are then removed by a vane separator and drained back into the scrub tank. When operated at a differential pressure of $127 \mathrm{~cm}$ of water, the unit is designed to remove over $90 \%$ of all particles greater than $0.5 \mu \mathrm{m}$ in diameter. Efficiency of removal increases with an increase in pressure differential.

(a) Hydro-Sonic scrubber is a product of Hydro Sonic Systems, Dallas, Texas. 


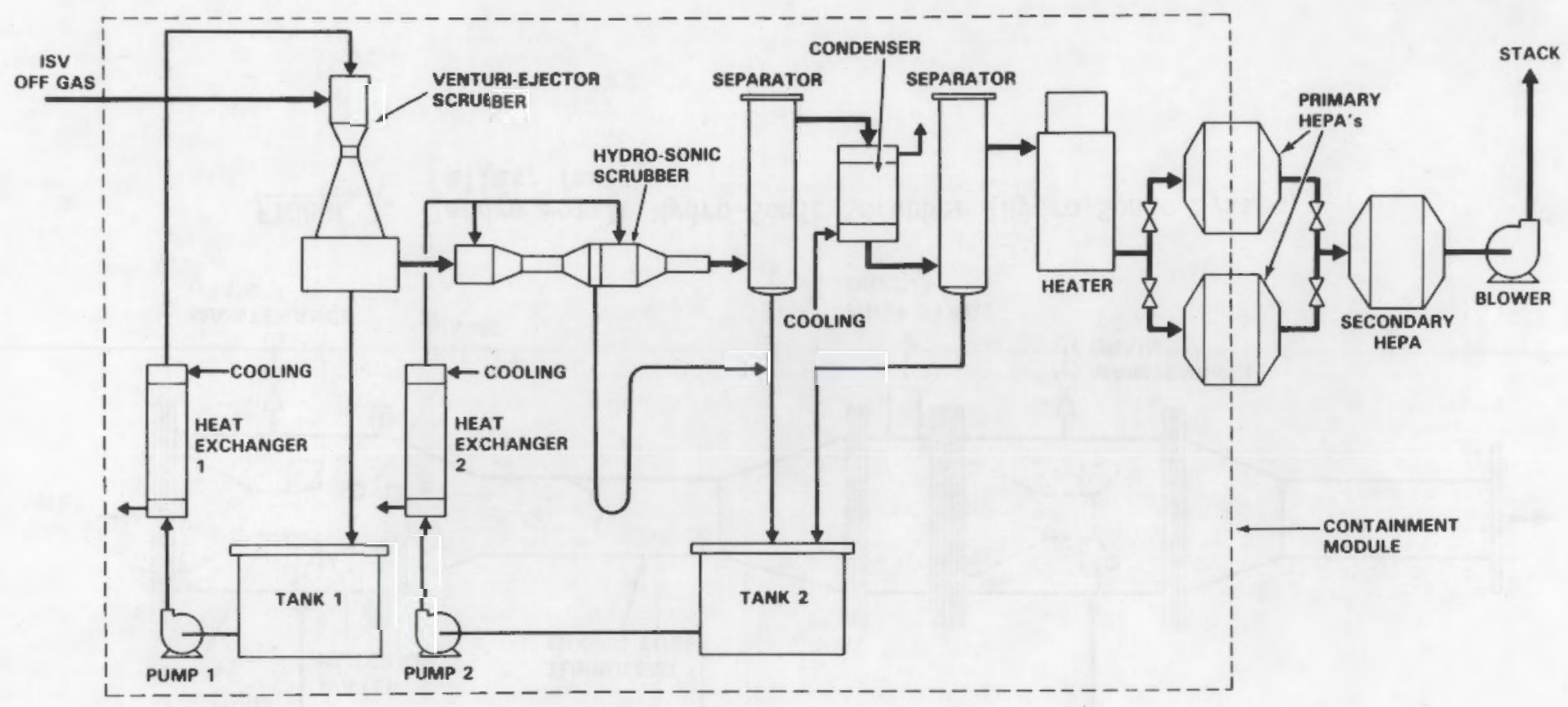

FIGURE 6. Schematic Drawing of the Pilot-Scale ISV Off-Gas Treatment System 


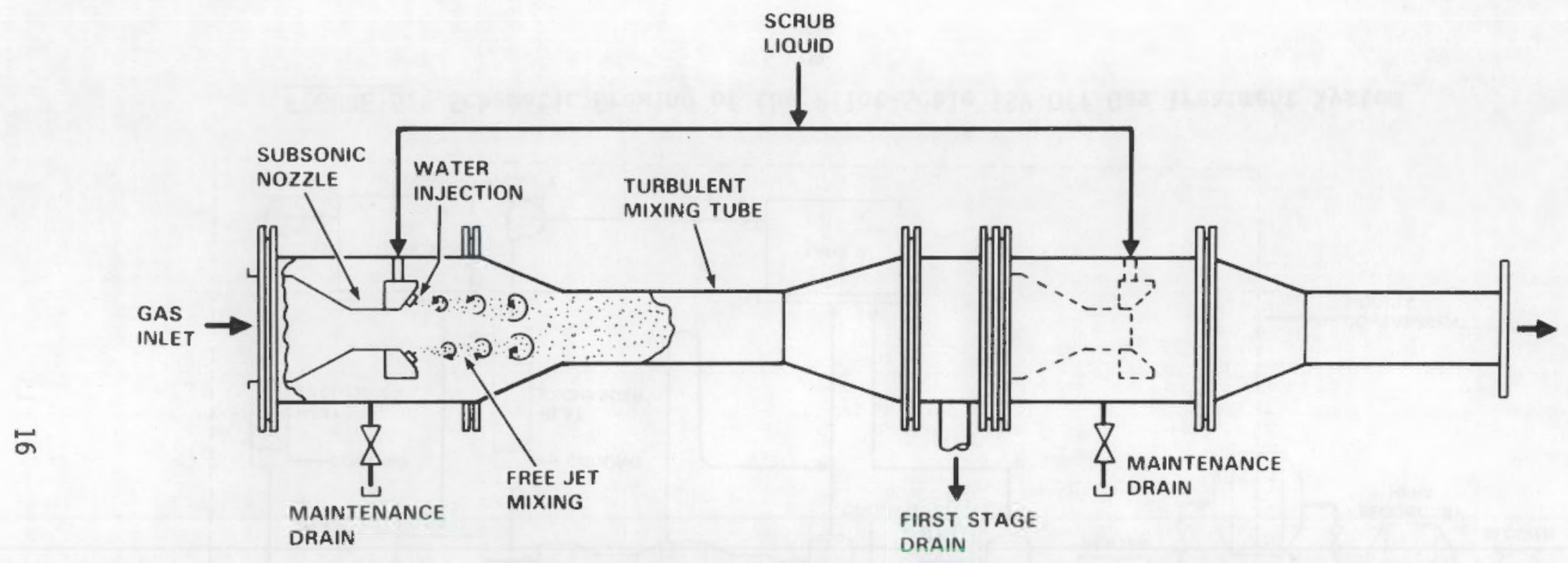

FIGURE 7. Tandem Mozzle Hydro-Sonic Scrubber (Hydro Sonic System, Dallas, Texas) 
Additional water is removed from the gas system by a condenser having a heat exchanger area of $8.9 \mathrm{~m}^{2}$ and a final separator. The gases are then reheated to approximately $25^{\circ} \mathrm{C}$ above the dew point in a $30 \mathrm{~kW}$ heater to prevent condensate carryover to the HEPA filters. The first stage of filtration consists of $61-\times 61-\times 29-\mathrm{cm}$ HEPA filters in parallel. During operation, one filter is used and the other remains as a backup in case the operating filter becomes loaded. The primary filter can be replaced during operation. The second-stage HEPA filter acts as a backup in case a first-stage filter fails. 



\subsection{IEST DESCRIPTIONS}

This section describes the pilot-scale ISV testing of ORNL soil and limestone, the associated off-gas processing equipment, and the specific procedures and operations used to characterize the ORNL ISV waste form.

\subsection{TEST PROCESS FOR ORNL ISV DEMONSTRATION}

The pilot-scale ISV demonstration test conducted at ORNL was designed to address key differences between conditions during previous tests of the ISV technology and those anticipated for full-scale remediation of a contaminated site at ORNL. For example, the waste trenches at ORNL contain large quantities of ${ }^{137}$ Cs that could volatilize at high temperatures and be carried into the process trailer with the off-gas, resulting in additional exposure to operators and producing excess wastes. Therefore, it was necessary that the retention factors of $>10,000$ for Cs (Cs in melted soil divided by Cs in offgas) obtained in engineering-scale tests (Carter, Bates and Maupin 1987) be confirmed at a larger scale under field conditions. Also, the soils at ORNL are more structurally and chemically heterogenous than those used in previous tests at Hanford. The trench design, with a significant quantity of crushed limestone present, resulted in a bulk composition of the melt lower in silica and higher in calcium than previously studied compositions (Buelt et al. 1987). Thus, the operational performance of the ISV technology, as well as the long-term durability of the resulting waste form, was addressed specifically for the ORNL site. Some of these issues were investigated during laboratory and engineering-scale test conditions at PNL during 1985 through 1986 (Carter, Bates and Maupin 1987). Evaluations of ISV technology on the pilot-scale test in actual soil at ORNL provide more reliable scale-up predictions.

Trench 7 (see Figure 1 and 2) was chosen as a model because of its size, inventory characteristics, and the fact that much characterization of the trench has already been accomplished (01sen et al. 1983). To enable the pilot-scale ISV system to be used, a 3/8-scale model of trench 7 was constructed in a pristine (i.e., uncontaminated) portion of ORNL (see Figure 1). 
The site, located on top of a ridge in the Maryville Limestone (an interlayered limestone-shale), was chosen for the similarity of its physical and geological characteristics to the area previously used for seepage disposal at ORNL (Figure 8). After preparation of the site (e.g., clearing, leveling, electrical service), the trench was constructed perpendicular to the strike of the bedding. The 9.2-m-long trench was $1 \mathrm{~m}$ wide at the top and tapered to $0.4 \mathrm{~m}$ at the bottom. A schematic cross section at the midpoint of the trench is shown in Figures 9, 10, and 11. The trench was constructed to a depth of $1.5 \mathrm{~m}$, except for the central section, which was excavated to a depth of $2.5 \mathrm{~m}$ to allow for the placement of a vertical array of eight type- $\mathrm{K}$ thermocouples (one thermocouple at every $0.31 \mathrm{~m}$ depth) for monitoring the depth of the melt.

To simulate the contaminated sludge that is present in Trench $7,526 \mathrm{~kg}$ of an $18 \mathrm{wt} \% \mathrm{Cs}-$ and $82 \mathrm{wt} \% \mathrm{Sr}$-carbonate mixture was placed in the central portion of the trench within the square electrode array (Figure 12). These quantities of $\mathrm{Cs}$ and $\mathrm{Sr}$ were selected to yield a waste form with sufficient concentrations of $\mathrm{Cs}$ and $\mathrm{Sr}$ that their leach characteristics could be determined. The entire trench was then filled from the $0.6-$ to $1.5-\mathrm{m}$ level with limestone. The upper $0.6 \mathrm{~m}$ of the trench was backfilled with original soil.

In addition to the array of thermocouples in the center of the trench, type- $\mathrm{K}$ thermocouples were placed at depths of $0.6 \mathrm{~m}, 1.2 \mathrm{~m}$, and $1.5 \mathrm{~m}$ along both sides of the trench at distances of $2.1 \mathrm{~m}$ and $3.1 \mathrm{~m}$ from the center of the trench. Three type-R thermocouples, which have a higher maximum operating temperature than type- $K$ thermocouples, were placed in a vertical array at the center of the trench at depths of $0.9,1.5$, and $2 \mathrm{~m}$ in an ultimately unsuccessful attempt to monitor melt temperatures. Moisture detection cells were placed in the trench at several locations but did not function properly and will not be discussed further.

The four molybdenum electrodes ( $5 \mathrm{~cm}$ diameter and $3.7 \mathrm{~m}$ long) were placed in graphite sleeves $(15 \mathrm{~cm} \mathrm{0.D.)}$ and placed $1.2 \mathrm{~m}$ apart in a square array of augured holes approximately $2.5 \mathrm{~m}$ deep. The off-gas hood was then placed over the trench and connected to the off-gas treatment system. The 


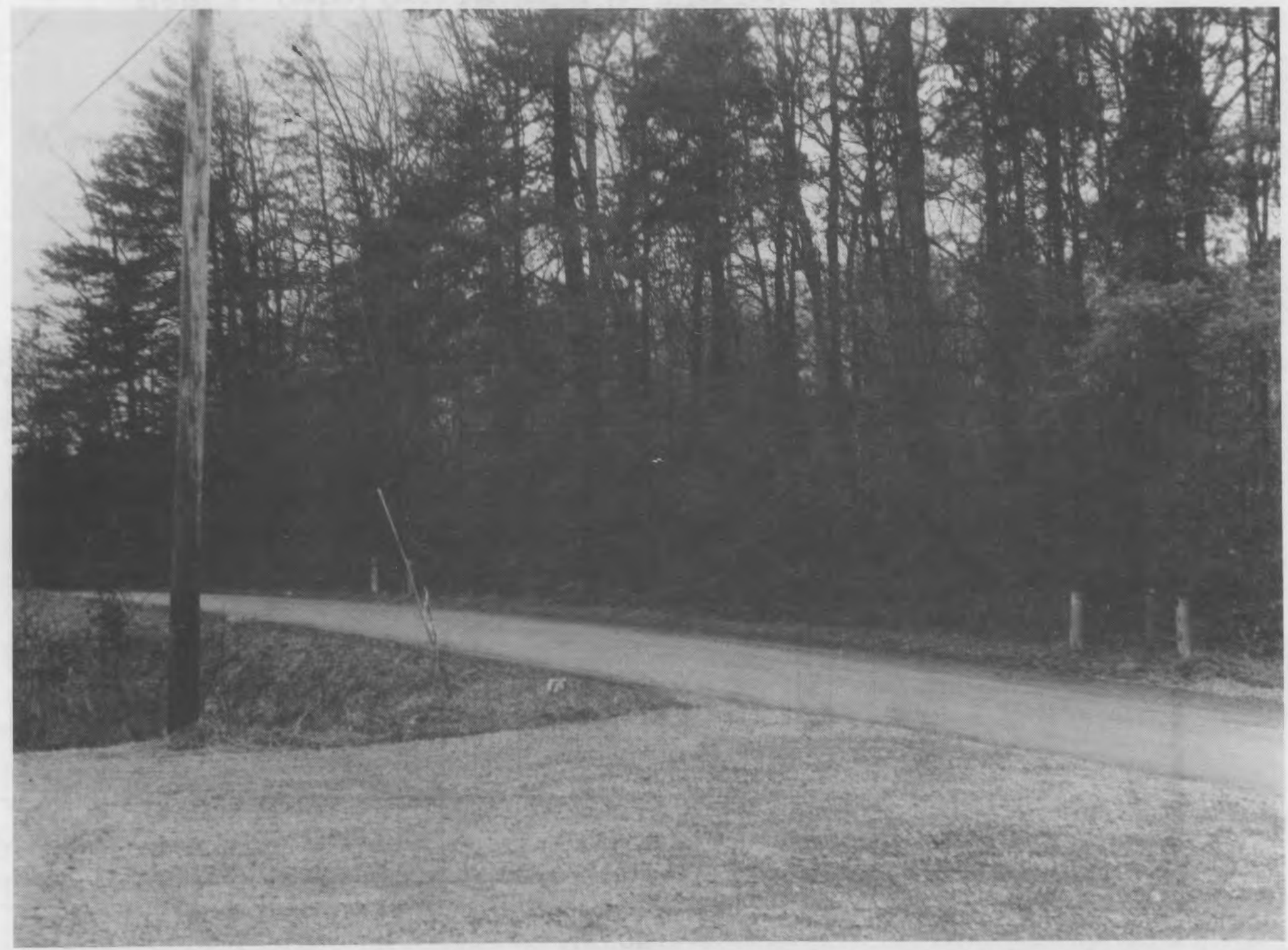

FIGURE 8. Pilot-Scale Test Site Prior to Site Preparation 


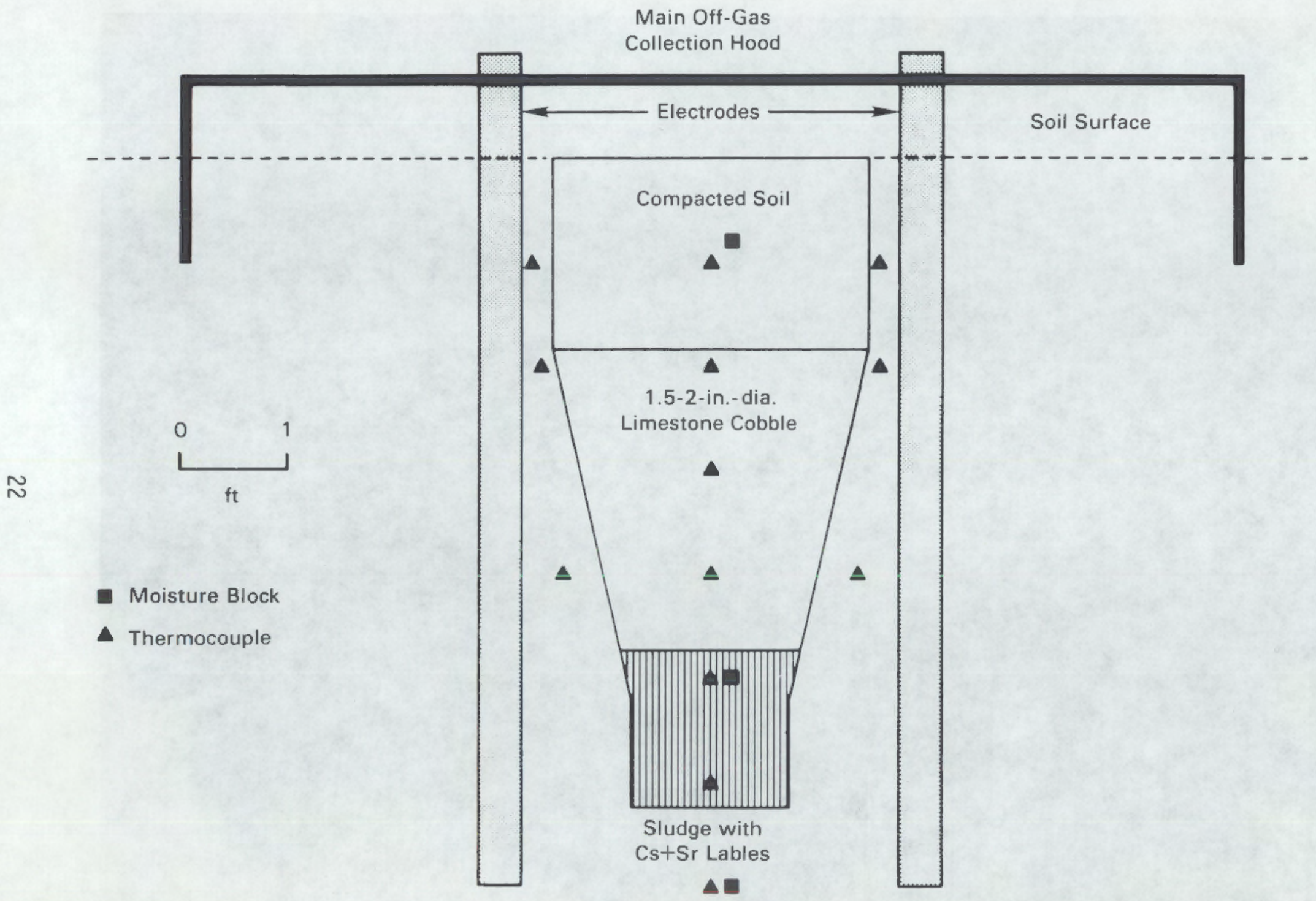

FIGURE 9. Central Cross Section of the Pilot-Scale ISV Demonstration Trench (approximate scale) 


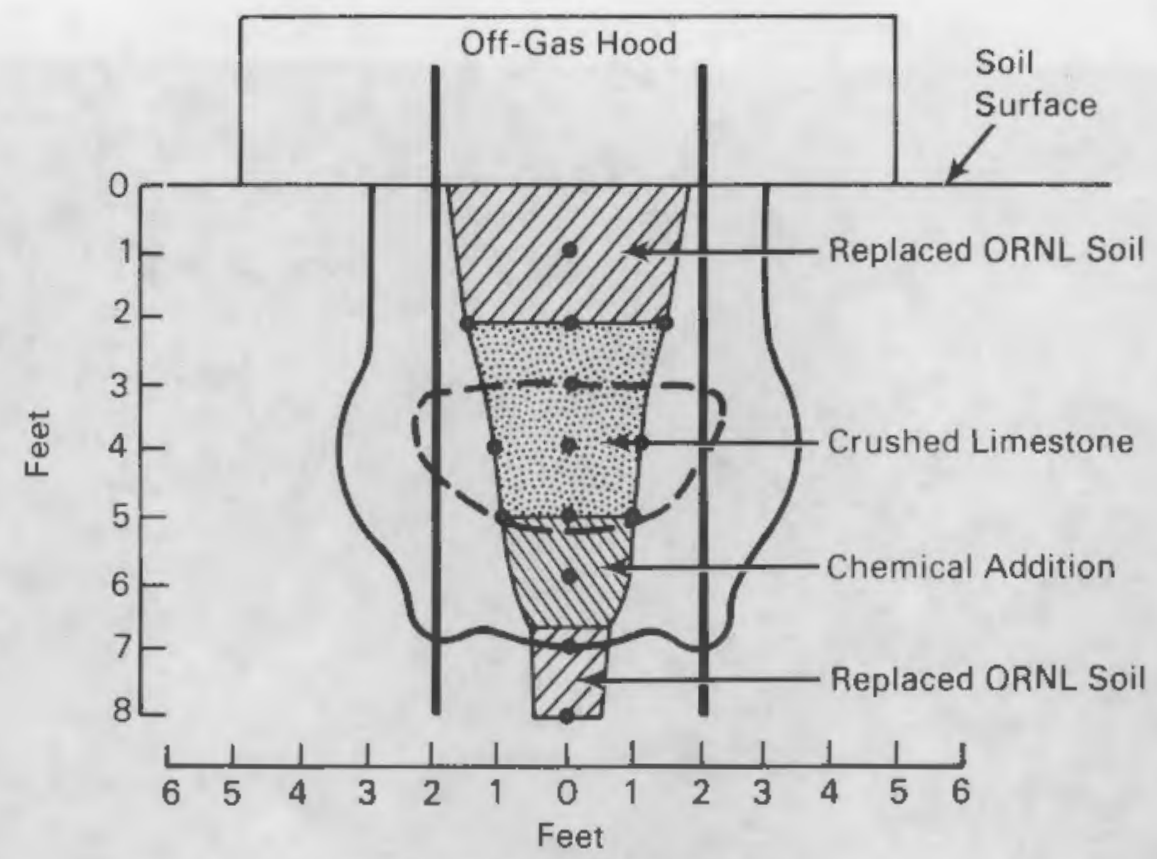

End View Look South to North
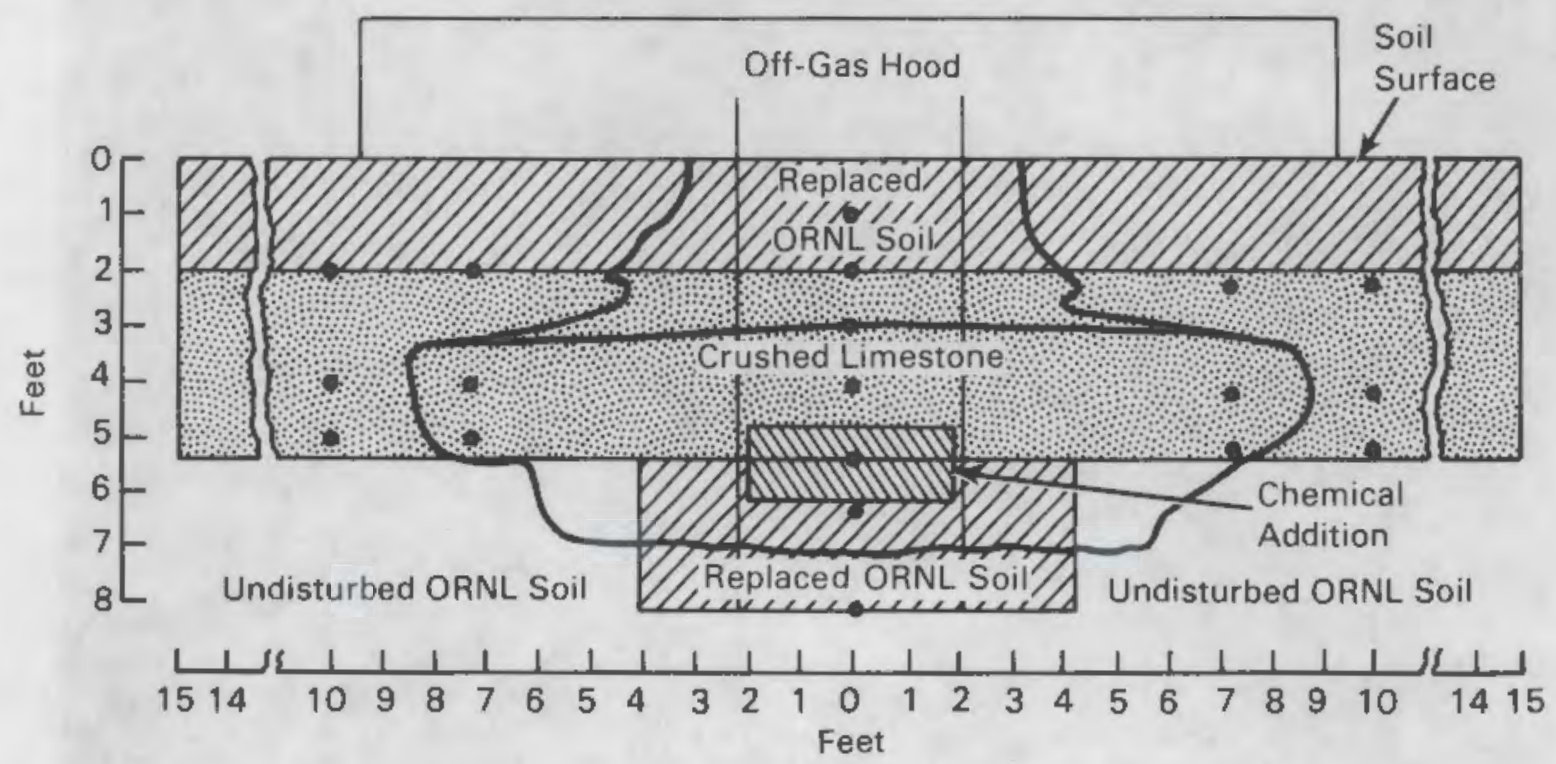

Side View Look West to East

FIGURE 10. Predicted Shape of the Pilot-Scale ISV Mass (overlayed on the original trench dimensions) 


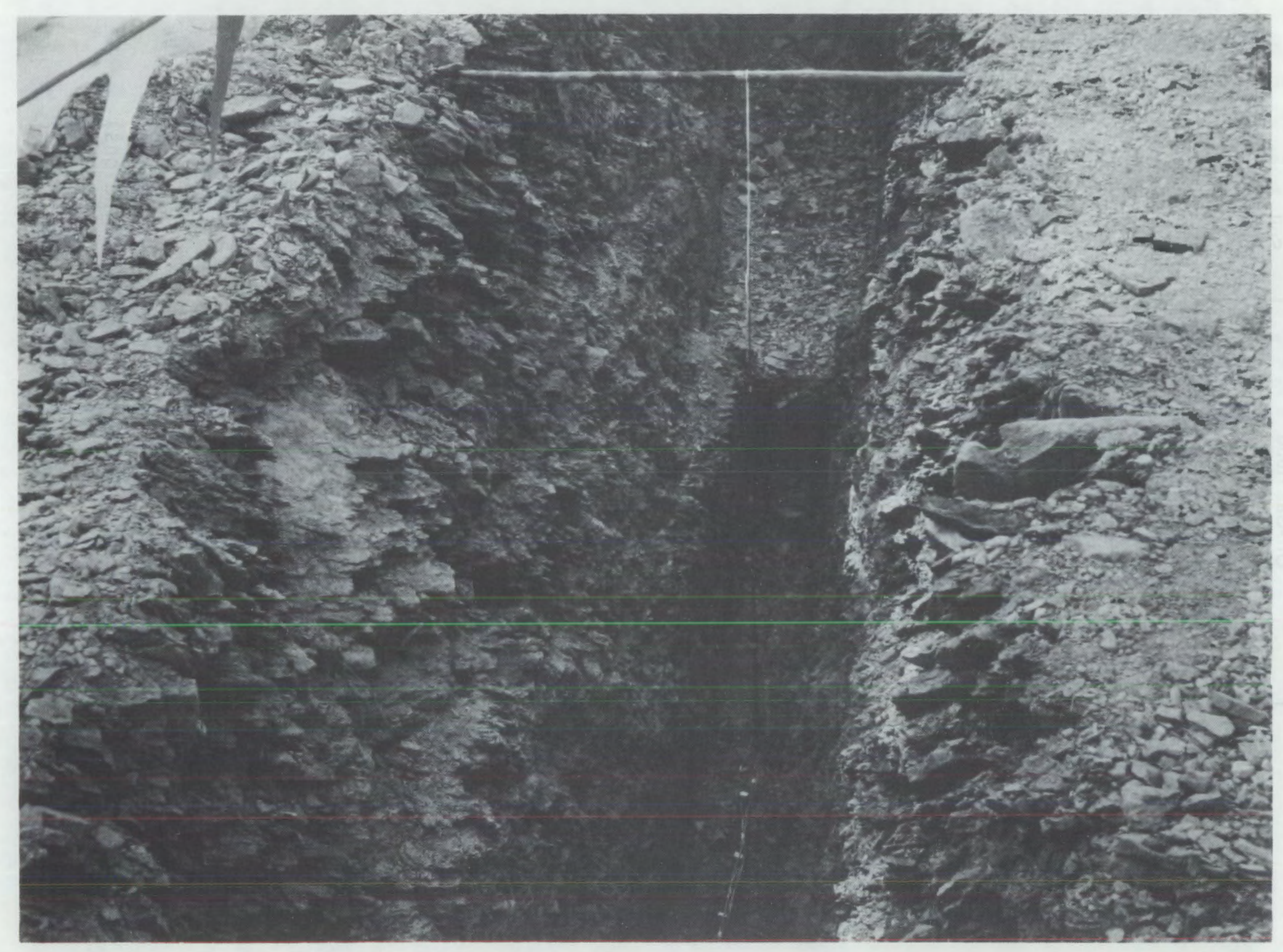

FIGURE 11. Excavation of the 3/8-Scale Model of Trench 7 


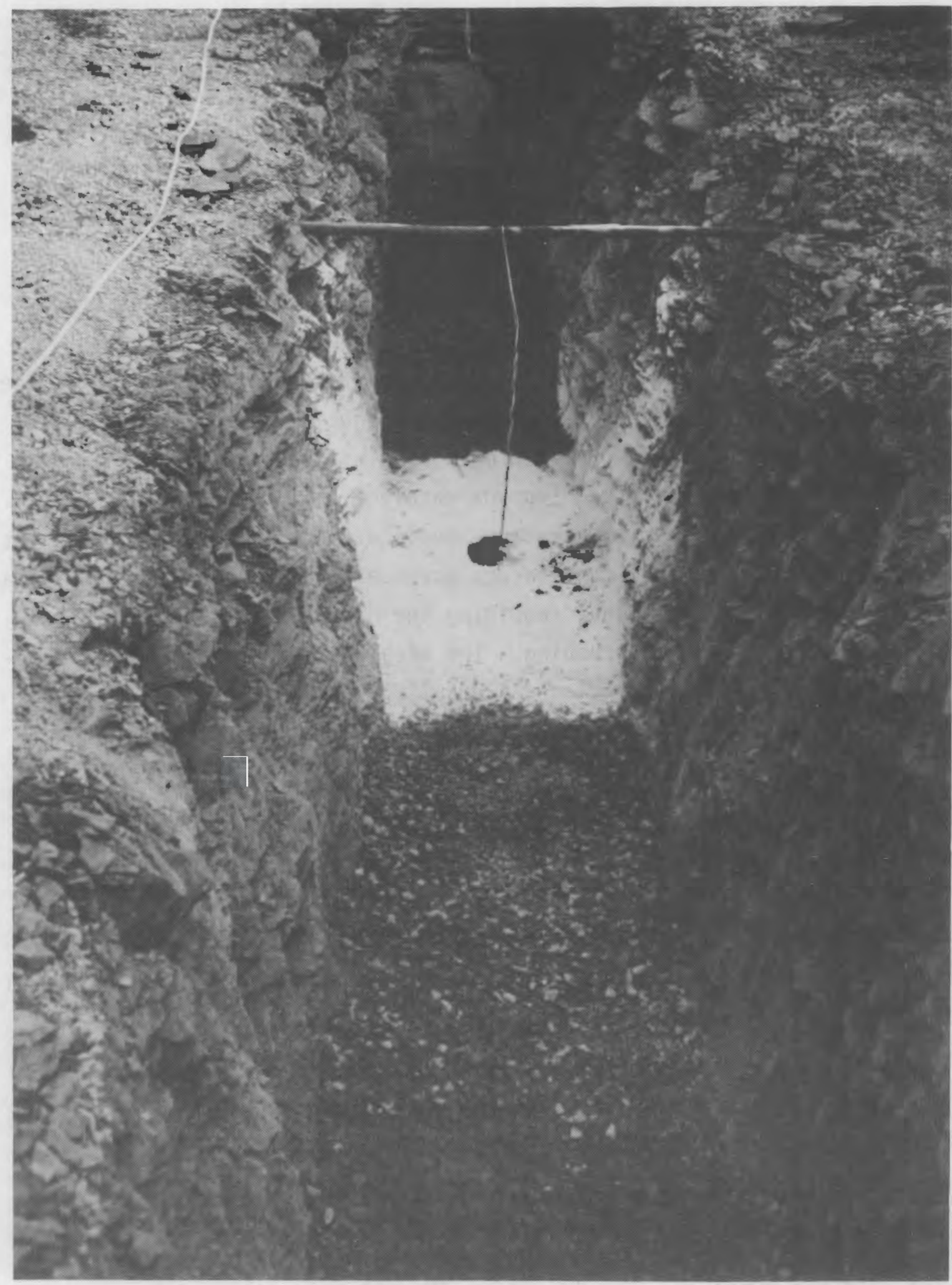

FIGURE 12. View of Chemical and Crushed Limestone as Placed in the 3/8-Scale Trench 
electrodes were connected to the power delivery system. Run data (e.g., temperatures, off-gas flow rate and $\mathrm{CO}$ and $\mathrm{CO}_{2}$ concentrations, electrical parameters) were recorded every 6 minutes and logged into a computerized data storage system. Off-gas scrub solution samples were collected approximately every 2 hours; duplicate samples were obtained for analysis at both PNL and ORNL.

The ISV test was scheduled to begin on June 26, 1987, but transformer circuitry malfunctions resulted in delay. The manufacturer repaired and tested the transformers and the ISV test was restarted on July 14, 1987. The test ran continuously for $110 \mathrm{~h}$ until power was shut off on July 19. Soil temperatures and manual probing of the melt zone with a steel rod confirmed that the desired depth of melting (approximately $2.1 \mathrm{~m}$ ) had been reached. During the $110 \mathrm{~h}$ of continuous operation, one equipment failure occurred. At $5 \mathrm{~h}$ into the test the pump to the venturi scrubber was shut down because of a leak in the pump surge tank, thus requiring the Hydro-Sonic scrubber to perform all the off-gas stream scrubbing. The single scrubber has proven effective in this performance (Timmerman and Oma 1984) and was actually designed to handle such an occurrence.

Table 2 shows predicted and actual operating data obtained from the ISV/ORNL pilot-scale test. Predicted data is based on a mathematical model developed for ISV (Buelt et al. 1987). In reviewing the data, note the differences when comparing the actual test results to the model predictions. The computer model bases the prediction on the production of a square, symmetrical melt area and does not account for the vitrification down the length of the trench that was observed during the ORNL test (see Figure 10).

A description of the vitrified mass as observed after hood removal, during core drilling, and as the mass was later exposed for mass sampling is given below:

- Subsidence from the surface was $0.91 \mathrm{~m}$ (36 in.), giving a volume reduction of $43 \%$.

- Two cold cap surfaces were observed. The top cold cap surface was at a depth $0.41 \mathrm{~m}$ (16 in.) from the soil surface, and the second 
TABLE 2. Predicted and Actual Data Obtained from ISV/ORNL Pilot-Scale Test

\begin{tabular}{lcc} 
& Predicted & Actual \\
\cline { 2 - 3 } \cline { 3 - 3 } Run Time, $\mathrm{h}$ & 54.6 & 110 \\
Melt Depth, m & 2.19 & 2.13 \\
Me1t Width, m & 2.57 & $-(\mathrm{a})$ \\
Melt Length, m &.$--(\mathrm{b})$ & 3.8 to 5.34 \\
ISv Mass, 1000 kg & 16.3 & $22.9(\mathrm{c})$ \\
Average Power, kW & 309 & 263 \\
Energy, 1000 kWh & 16.9 & 28.9 \\
Energy/Mass, kWh/kg & 1.04 & 1.26
\end{tabular}

(a) Actual width measurements of the vitrified mass were not taken because the vitrified mass was not completely exhumed.

(b) Model actually predicts a symmetrical block of equal width and length.

(c) The ISV mass is a calculated number from the CS retention quantities. The vitrified mass was not exhumed to obtain actual weights or measurements. The calculation is Cs addition to test site

was the melt surface at a depth of $0.91 \mathrm{~m}$. The top cold cap thickness was up to $5.0 \mathrm{~cm}(2 \mathrm{in.})$ and had little structural strength. Because the cold caps had little structural strength and would collapse during backfilling, there would be no concerns for future subsidence over the trench.

- The side walls of the subsided surfaces were vertical, with a thickness of $1.3 \mathrm{~cm}(1 / 2 \mathrm{in}$.$) . The surface that traversed the$ length of the trench had void surfaces between the replaced ORNL soil and the area filled with limestone. As noted in the engineering-scale test, sloughing of the crushed limestone material could occur during the pilot-scale test. Because of the information on sloughing obtained during the engineering-scale test, the hood for the pilot-scale test was lengthened to accormodate potential sloughing. 
- The surface of the melt zone was very smooth at first observation, but core drilling revealed a porous area containing very small bubbles to a depth of 6.4 to $7.5 \mathrm{~cm}$ (2.5 to 3 in.).

- The soil around the exhumed section of the vitrified mass had changed to a red rusty color, as seen in earlier tests. This indicated a ferrous-to-ferric ratio change due to oxidation at temperatures between $200^{\circ} \mathrm{C}$ and $300^{\circ} \mathrm{C}$ but had no effect on the processing behavior.

- The vitrified mass contained a gray crystalline material with the largest concentration of the gray material between the electrodes. This gray crystalline material is explained in detail in the Devitrification Section of this report.

\subsection{PROCESS EQUIPMENT EVALUATION AND PERFORMANCE}

This section evaluates the electrical system and the performance of the process scrubber system.

\subsubsection{Electrical System}

The electrical data obtained from the pilot-scale test are shown in Figure 13, which gives A-phase and B-phase volts versus run time, and Figure 14, which gives A-phase and B-phase amps versus run time. Figure 15 shows total power (kilowatts) versus run time, while figure 16 shows cumulative energy (megawatt-hours) versus run time. These curves show typical ISV electrical system operation where the voltage decreases, with melt growth and corresponding lower resistivity, requiring higher amperage to maintain constant power. Figure 17 shows the depth of the vitrified mass during the processing period derived from thermocouples imbedded in the trench. As the molten glass approaches a thermocouple, the soil temperature increases to $100^{\circ} \mathrm{C}$ and remains as the moisture is driven off. The temperature rapidly increases off-scale as the molten glass reaches the thermocouple. 


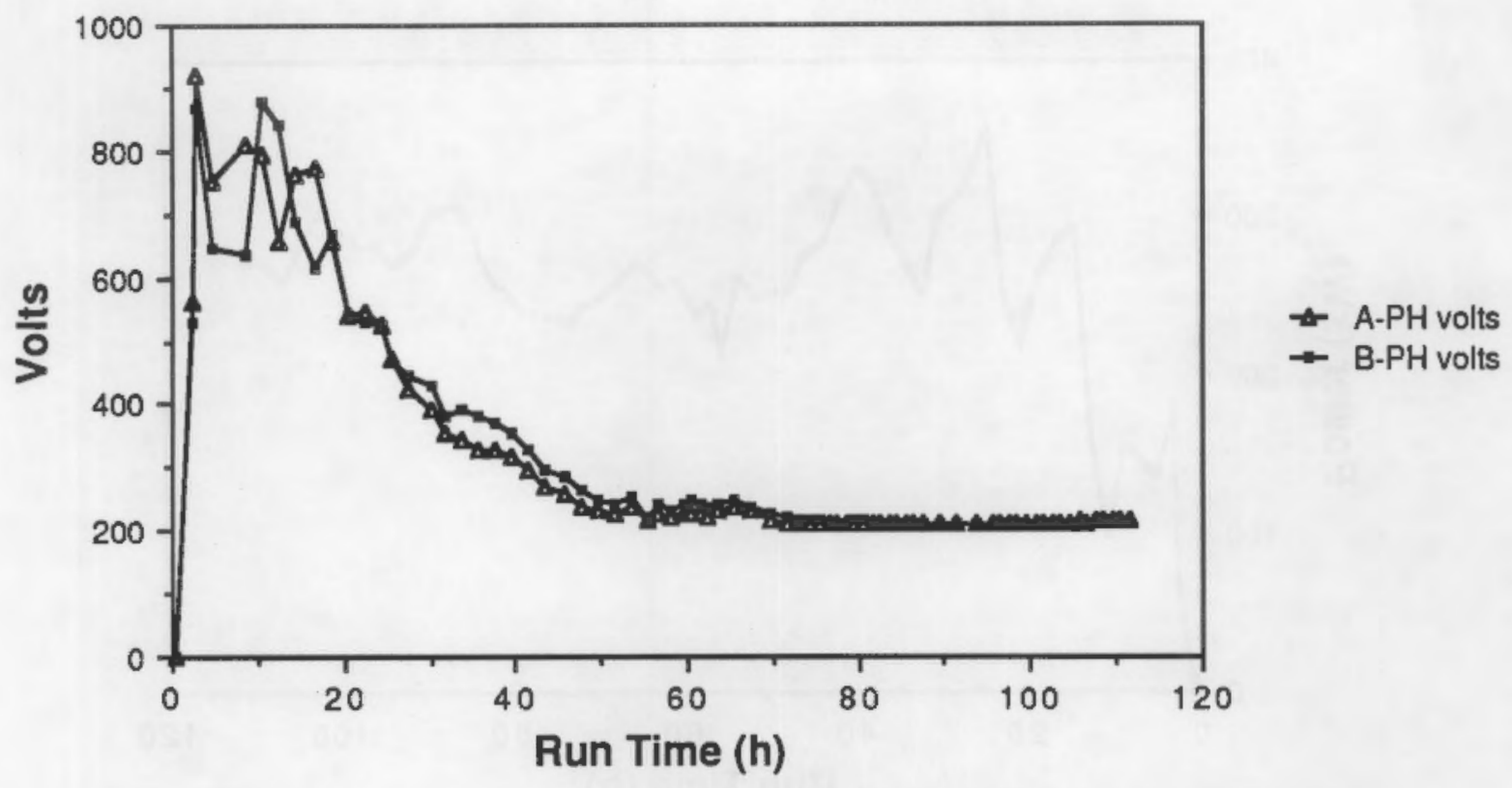

FIGURE 13. A-Phase and B-Phase Voltage Versus Run Time

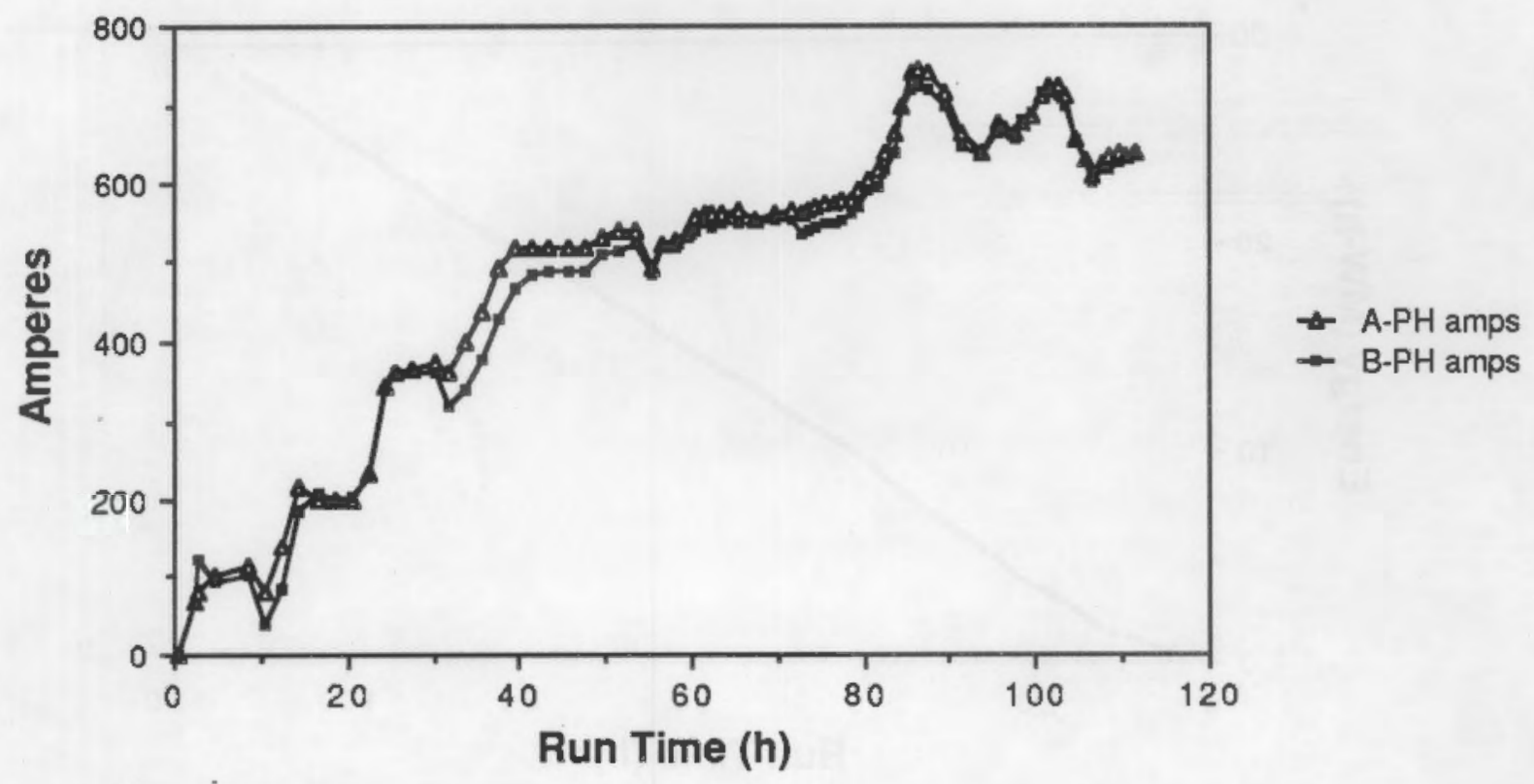

FIGURE 14. A-Phase and B-Phase Amperages Versus Run Time 


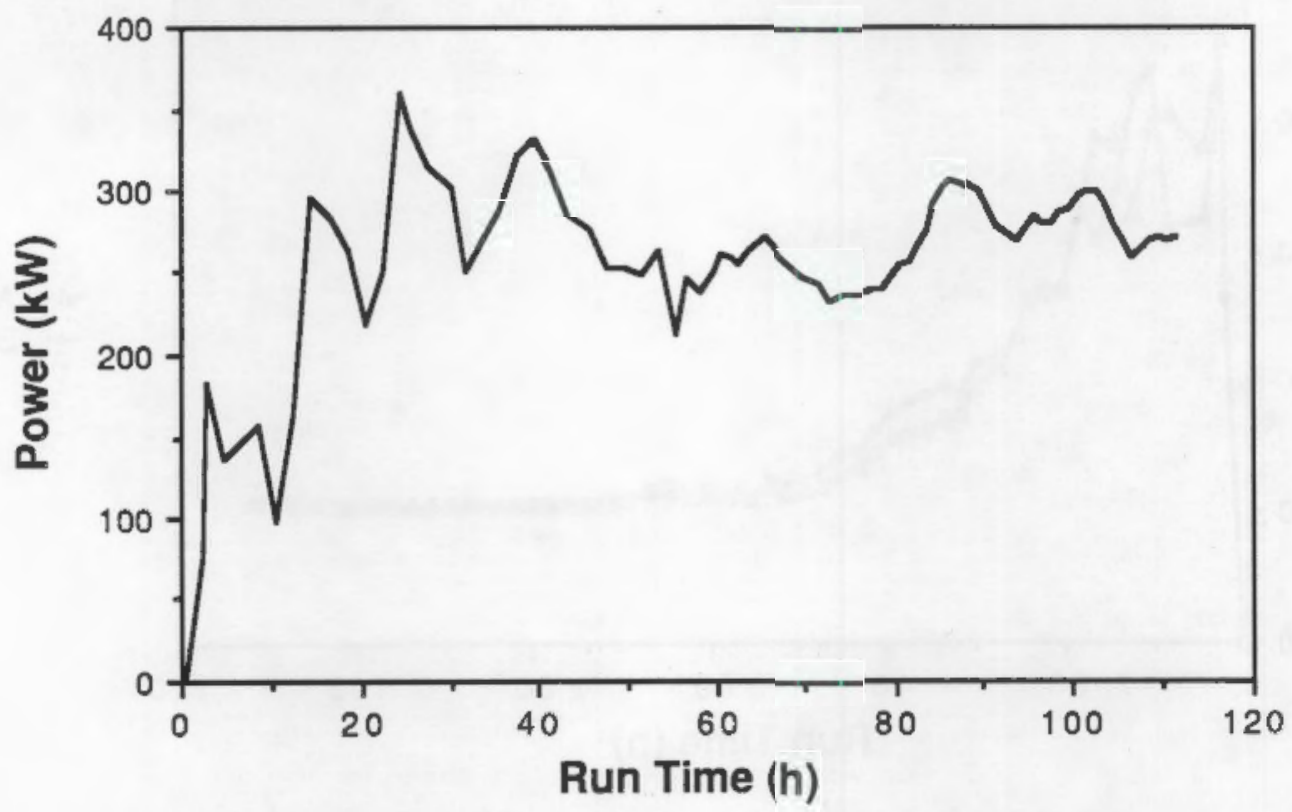

FIGURE 15. Total Power (kilowatts) Versus Run Time

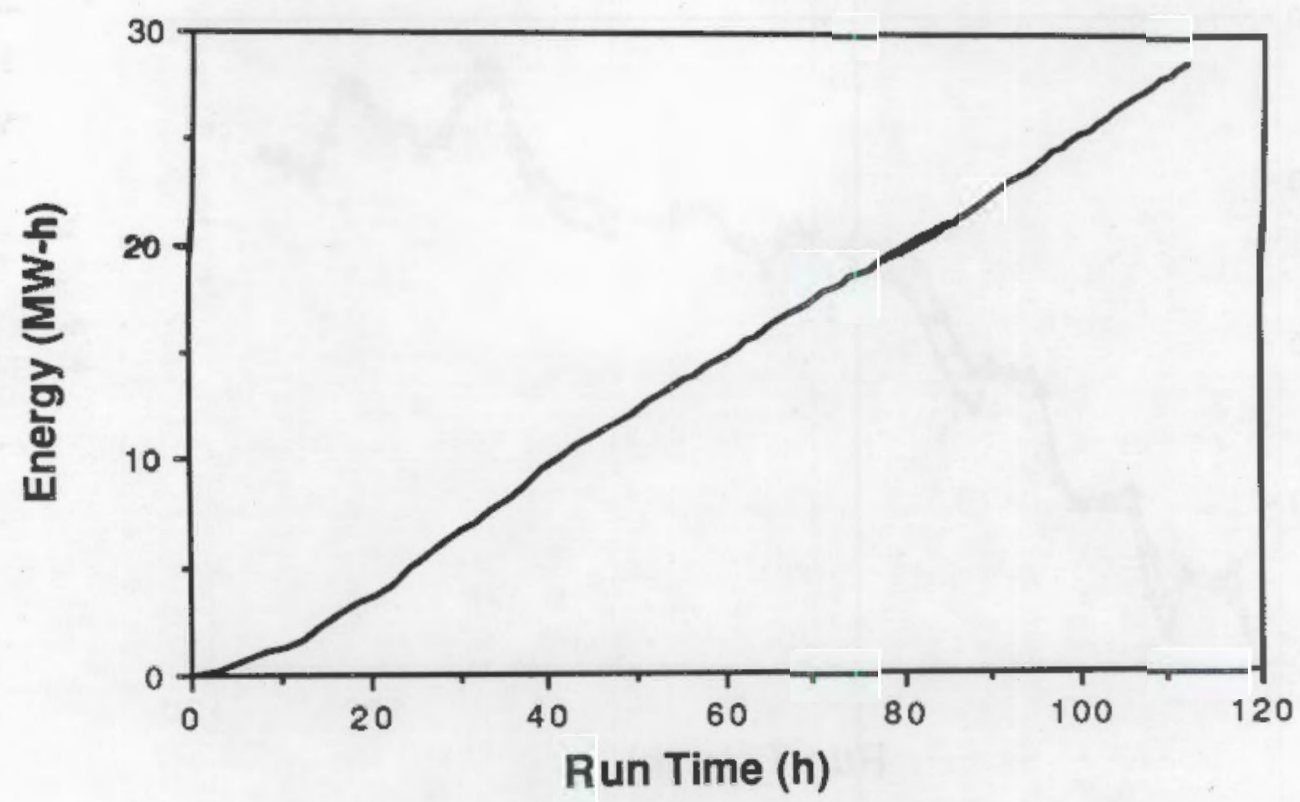

FIGURE 16. Cumulative Energy (megawatt-hours) Versus Run Time 


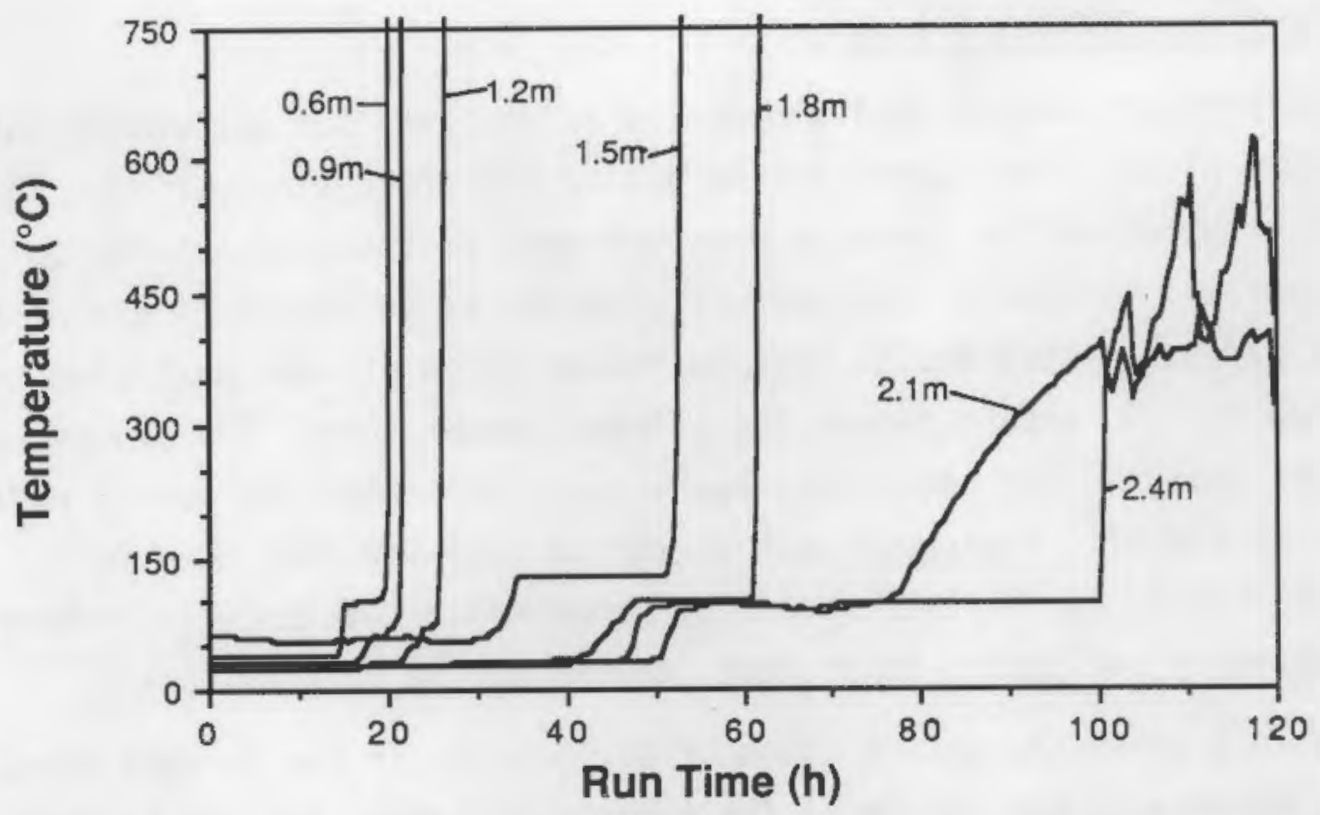

FIGURE 17. Temperature and Vitrified Mass Depth Versus Run Time

After one false start on June 26, 1987 (a result of a transformer circuitry malfunction) power was continuously applied to the electrodes for $110 \mathrm{~h}$ starting July 14, 1987. The voltage applied to the transformer was manually controlled for this operating period.

The electrodes performed acceptably during the entire demonstration. At the completion of demonstration the upper sections of the electrodes were removed from the melt interface surface and inspected. The sacrificial graphite sleeves placed over the molybdenum electrodes oxidized in two locations on the four electrodes. The electrode oxidation occurred at the locations of the two subsided areas described in Section 5.1. No oxidation of the molybdenum electrode was observed on any of the four electrodes. Oxida$t$ tion of the molybdenum was prevented by the molybdenum disilicide/zirconium diboride electrically conductive powder placed in the annulus between the molybdenum electrodes and the graphite sleeves. Where the graphite sleeves oxidized away, the conductive powder formed a sintered coating that protected the molybdenum electrode surfaces. 


\subsubsection{Process Off-Gas System}

The process off-gas system operated as designed for the demonstration test. One piece of equipment failed during the processing period. This failure occurred within the pump pressure tank that supplies scrub solutions to the venturi scrubber. The venturi scrubber is at the front end of the process off-gas system and is used to remove large off-gas particles entering the scrub system, and to reduce the off-gas temperature. The process off-gas system is designed for continuous operations, even when processing radionuclides, if specific equipment such as the venturi scrubber pump fails. Particulate removal by the hydro-sonic scrubber while the venturi scrubber is inoperative is sufficient to prevent loading of the HEPA filters.

Table 3 shows the accumulation of particulate in the process scrub solutions. Because of the design of the processing tanks, large quantities of particulate are transferred from the tank bottoms (particulate not in suspension) during each transfer. The total particulate accumulated was verified by the quantities accumulated and analyzed by ORNL in the waste drums generated during the ISV test. No particulate sizing analysis was performed during the ISV test. Sizing data from previous pilot-scale radioactive tests indicate that mass loading of entrained particles downstream of the hydrosonic scrubber averaged $0.8 \mathrm{mg} / \mathrm{m}^{3}$. The mass mean particle diameter averaged less than $0.5 \mu \mathrm{m}$, the approximate lower limit of the hydro-sonic scrubber (Oma and Timmerman 1984).

Evaluation of the pilot-scale processing equipment showed the accumulations and quantities of $\mathrm{Cs}$ and $\mathrm{Sr}$ in the following process locations. (See Appendices A and B, respectively, for sample calculations and sample concentrations. Appendix $E$ describes the analytical procedures that were used.)

- Off-gas hood

- Off-gas line

- Process scrub solutions

$$
\begin{aligned}
& C s=0.02 \mathrm{~g} \\
& \mathrm{sr}=0.01 \mathrm{~g} \\
& \mathrm{Cs}-0.10 \mathrm{~g} \\
& \mathrm{sr}-0.0013 \mathrm{~g} \\
& \mathrm{Cs}-69.534 \mathrm{~g} \\
& \mathrm{sr}=0.133 \mathrm{~g}
\end{aligned}
$$


TABLE 3. Particulate Accumulation in Scrub Solutions

\begin{tabular}{|c|c|c|c|c|c|c|}
\hline $\begin{array}{c}\text { Run } \\
\text { Hours }\end{array}$ & $\begin{array}{c}\text { Tank } \\
\text { Volume } \\
\text { (L) } \\
\end{array}$ & $\begin{array}{c}\text { Tank } \\
\text { Transfer } \\
\text { (L) } \\
\end{array}$ & $\begin{array}{l}\text { Solids } \\
\text { (mg/L) }\end{array}$ & $\begin{array}{c}\text { Total } \\
(g) \\
\end{array}$ & $\begin{array}{c}\text { Transfer } \\
\text { Out } \\
\text { (g) } \\
\end{array}$ & $\begin{array}{l}\text { Cumulative } \\
(g)\end{array}$ \\
\hline 0 & 139 & 0 & 1837 & 254.6 & 0.0 & 254.6 \\
\hline 23.5 & 319 & 51 & 29400 & 9378.6 & 1499.4 & 9378.6 \\
\hline 25.5 & 316 & 31 & 24100 & 7615.6 & 747.1 & 9115.0 \\
\hline 30.2 & 307 & 0 & 21700 & 6661.9 & 0.0 & 8908.4 \\
\hline 35.5 & 326 & 48 & 16500 & 5379.0 & 792.0 & 7625.5 \\
\hline 39.5 & 324 & 30 & 10600 & 3434.4 & 318.0 & 6472.9 \\
\hline 43.5 & 323 & 27 & 8070 & 2606.6 & 217.9 & 5963.1 \\
\hline 45.3 & 304 & 0 & 6280 & 1909.1 & 0.0 & 5483.1 \\
\hline 49.5 & 374 & 23 & 5080 & 1645.9 & 116.8 & 5220.3 \\
\hline 55.5 & 326 & 32 & 3610 & 1176.9 & 115.5 & 4868.0 \\
\hline 57.5 & 305 & 0 & 3290 & 1003.5 & 0.0 & 4608.1 \\
\hline 61.4 & 322 & 33 & 2630 & 846.9 & 86.8 & 4653.6 \\
\hline 63.5 & 308 & 0 & 2320 & 714.6 & 0.0 & 4810.2 \\
\hline 67.5 & 333 & 19 & 1900 & 632.7 & 36.1 & 4526.2 \\
\hline 69.5 & 327 & 18 & 1710 & 559.2 & 30.8 & 4488.8 \\
\hline 71.8 & 310 & 9 & 1440 & 446.4 & 13.0 & 4406.8 \\
\hline 73.4 & 315 & 15 & 1390 & 437.9 & 20.9 & 4411.2 \\
\hline 75.4 & 300 & 0 & 1100 & 330.0 & 0.0 & 4324.2 \\
\hline 77.5 & 305 & 0 & 1220 & 372.1 & 0.0 & 4366.3 \\
\hline 81.4 & 331 & 28 & 1170 & 387.3 & 32.8 & 4381.5 \\
\hline 85.5 & 333 & 30 & 1030 & 343.0 & 30.9 & 4369.9 \\
\hline 87.5 & 323 & 35 & 1040 & 335.9 & 36.4 & 4393.8 \\
\hline 89.5 & 307 & 0 & 701 & 215.7 & 0.0 & 4309.4 \\
\hline 93.5 & 357 & 48 & 907 & 323.8 & 43.5 & 4418.0 \\
\hline 95.6 & 322 & 39 & 805 & 259.2 & 31.4 & 4397.0 \\
\hline 97.5 & 305 & 0 & 853 & 260.7 & 0.0 & 4429.3 \\
\hline 99.6 & 307 & 0 & 762 & 233.9 & 0.0 & 4403.1 \\
\hline 103.5 & 326 & 0 & 849 & 276.8 & 0.0 & 4445.9 \\
\hline 107.5 & 314 & 0 & 11900 & 3736.6 & 0.0 & 7905.8 \\
\hline 110.5 & 324 & 283 & 11600 & 3758.4 & 3282.8 & 7927.6 \\
\hline & 332 & 304 & 12200 & 4050.4 & 3708.8 & 11502.4 \\
\hline \multirow[t]{2}{*}{ FLUSH } & 381 & 277 & 12600 & 4800.6 & 4750.2 & 15961.4 \\
\hline & & & & 0.0 & $\overline{15911.0}$ & 15911.0 \\
\hline
\end{tabular}


- Process scrub solutions

$$
\begin{array}{cl}
\text { Cs }-63.51 \mathrm{~g} & \text { (These quantities } \\
\mathrm{Sr}-0.166 \mathrm{~g} & \text { are verification of } \\
& \text { the process scrub } \\
& \text { solution) }
\end{array}
$$

transferred out

- Process Primary HEPA filter Cs - $2.32 \mathrm{~g}$

$$
\mathrm{Sr}-0.003 \mathrm{~g}
$$

- Process final HEPA Filter Cs $-<0.001 \mathrm{~g}$

$$
\mathrm{Sr}-<0.001 \mathrm{~g}
$$

The following quantities of $\mathrm{Cs}$ and $\mathrm{Sr}$ were placed in the soil at the ORNL test site prior to vitrification (see Appendix A for Calculations):

$$
\begin{aligned}
\mathrm{Cs}_{2} \mathrm{CO}_{3} & =89,892 \mathrm{~g} \\
\text { expressed as } \mathrm{Cs} & =73,274 \mathrm{~g} \\
\mathrm{SrCO}_{3} & =408,600 \mathrm{~g} \\
\text { expressed as } \mathrm{Sr} & =236,931 \mathrm{~g}
\end{aligned}
$$

Using those quantities, the following DF and percent retention were determined:

$$
\begin{aligned}
\text { Cs DF } & =1.018 \mathrm{E}+3 \\
\text { Cs retention } & =99.90 \% \\
\text { Sr DF } & =1.394 \mathrm{E}+6 \\
\text { Sr retention } & =99.9999 \%
\end{aligned}
$$

Figure 18 shows the rate of total Cs accumulation in the process scrub tank solution as compared to the processing depth of the vitrified mass. The rate of $\mathrm{Sr}$ is not shown because of its high retention in the vitrified mass and hence its low concentration, and because of its near background level in the scrub solution samples.

Distribution of the $\mathrm{Cs}$ and $\mathrm{Sr}$ through the off-gas system provides data on the operational procedural requirements, projected results, and scrub 


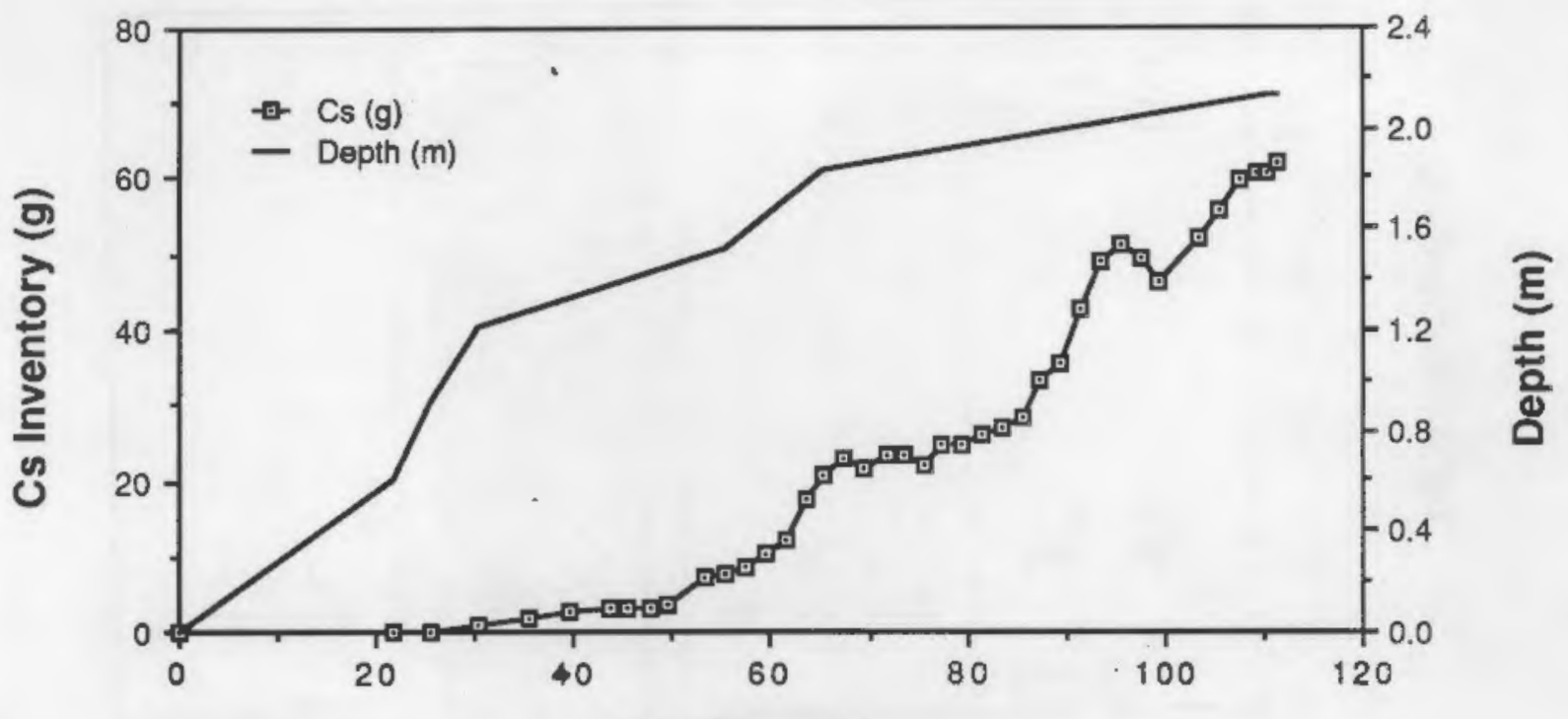

Run Time (h)

FIGURE 18. Total Cs Accumulation in Scrub Solution Versus Vitrified Mass Depth

efficiencies (Figure 19). The scrub system accounted for removal of $96 \%$ of cesium and $92 \%$ of $\mathrm{Sr}$ of the total release from the melt zone. The primary HEPA filter collected $3.5 \%$ of the $\mathrm{Cs}$ and $1.7 \%$ of the $\mathrm{Sr}$. The final HEPA filter had less than detectable levels of both $\mathrm{Cs}$ and $\mathrm{Sr}$. The remaining $0.5 \%$ is accounted for in the off-gas hood and off-gas line. These quantities compare closely with those previously reported for pilot-scale radioactive tests (Timnerman and Oma 1984). The venturi scrubber pump failure had no effect on process efficiency or system accumulations.

Other information that is not critical to operations calculation but would be useful for future design considerations is shown in Appendix $C$, Figures C.1 through C.6.

\subsection{MATERIAL CHARACTERIZATION STUDIES}

The objective of this evaluation was to characterize the composition and phase behavior properties of the ORNL ISV waste form. Because the primary duty of the ISV waste form is to contain the waste components, the waste form's durability is of prime importance and will also be described. 


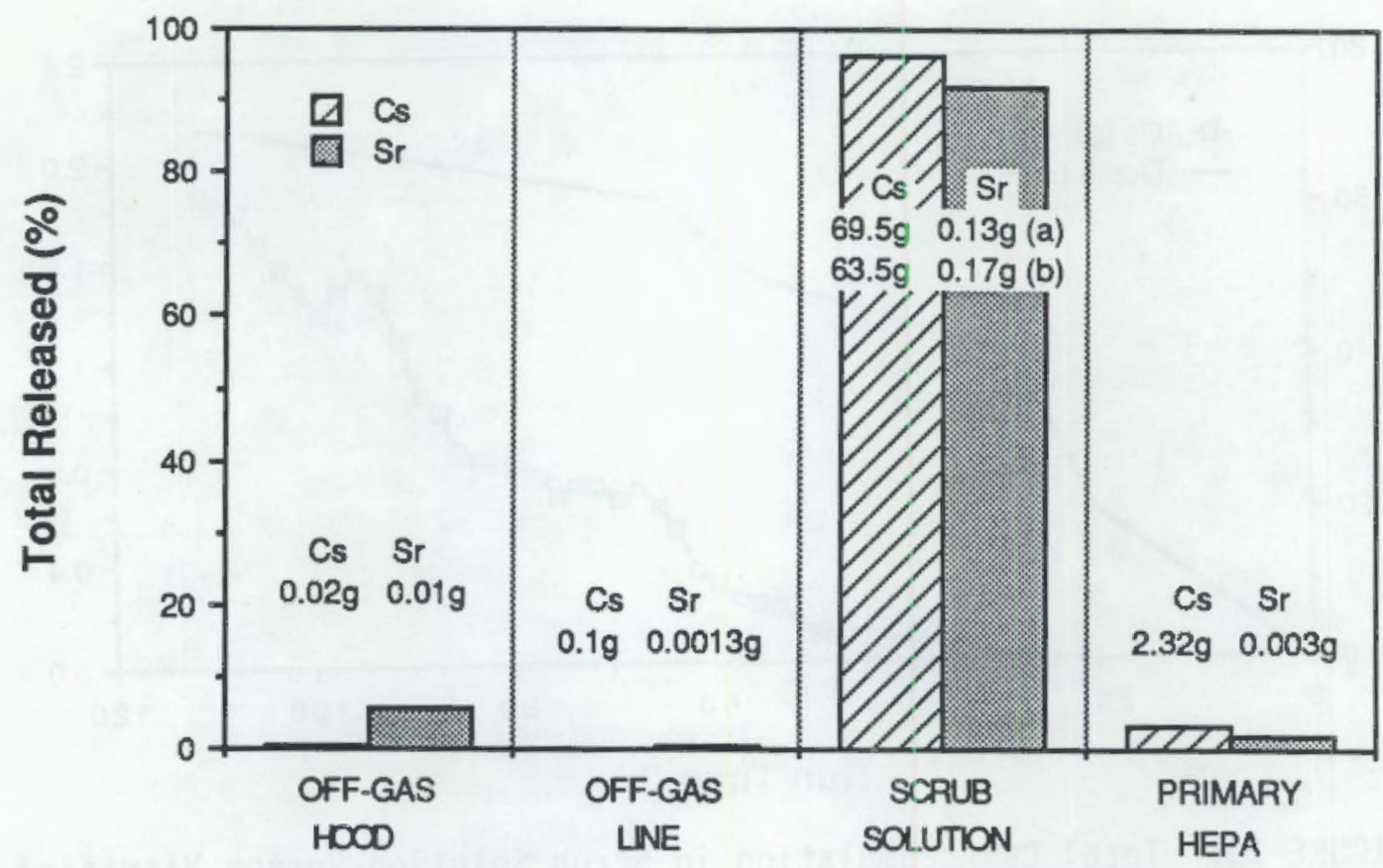

FIGURE 19. Distribution of $\mathrm{Cs}$ and $\mathrm{Sr}$ Released from Melt Zone (a) scrub solution sample quantities; (b) transferred scrub solution sample quantities

\subsubsection{Product Characterization}

Samples were received from cores 2 through 6 taken from the ISV monolith. The relative position of the cores with respect to the electrodes is shown in Figures 20 and 21. Visual observation of these samples found a frothy, vitreous area at the top of the cores, with the bulk of the core consisting of glass, a gray crystalline (rock) material, or a mixture of both glass and crystalline material. Some soil or calcined soil was also observed at the bottom of some of the deeper cores. Core 2, which was taken from near the center of the ISV monolith, was comprised almost entirely of the crystalline material. In contrast, core 4 consisted almost completely of glass. The remaining cores consisted of a mixture of both phases. Additional grab samples were received after the monolith was exposed by excavation. The relative positions of the grab samples are shown in Figure 22.

Four representative samples were selected for detailed evaluation. Because core 3 was typical of most of the other cores and represented all of the observed phases, three samples from this core were chosen for detailed 


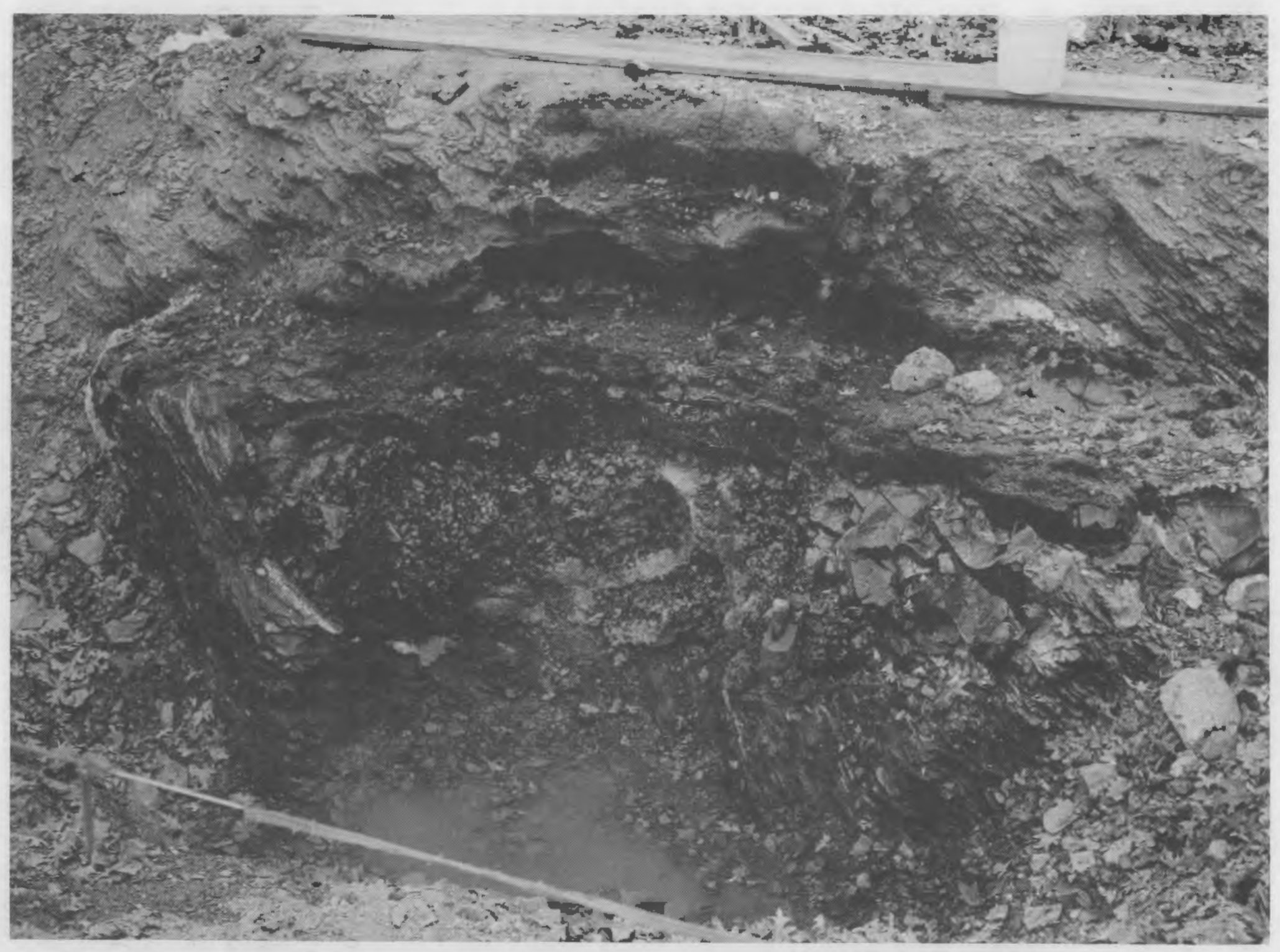

FIGURE 20. View of Vitrified Mass After Excavation and Sampling 


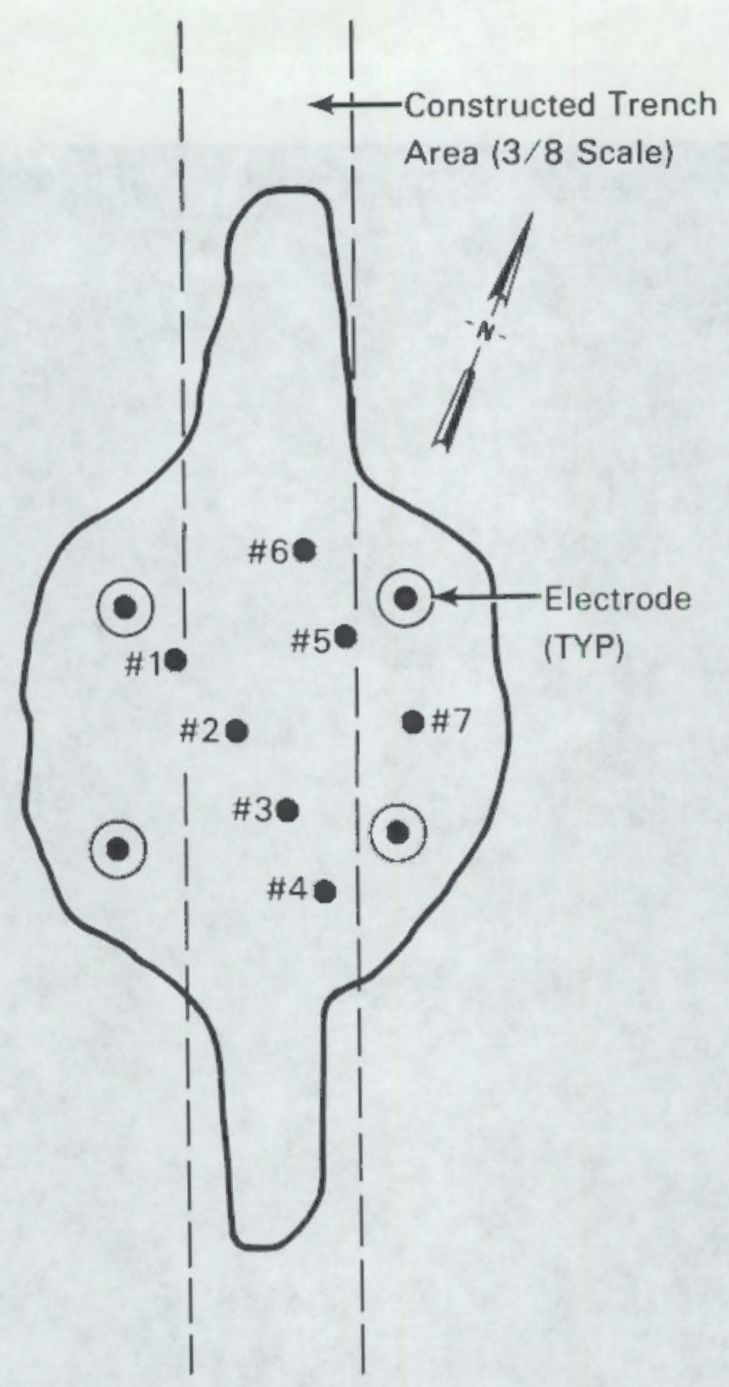

FIGURE 21. Relative Positions of Core Samples Taken from ORNL ISV Monolith

evaluation. These three samples consisted of a sample of the frothy glass from the surface of the monolith (sample \#230), the gray crystalline material (sample \#233), and a mixture of glass and crystalline material (sample \#232). Because the outer region and the major bulk of the ISV monolith was primarily glass, the vitreous phase of the monolith was also evaluated. A sample from core 4 was also chosen for detailed evaluation of the vitreous phase (sample \#231). Table 4 describes the location from which these samples were taken.

\subsubsection{Sample Composition}

Elemental analysis of the four samples was conducted by inductively coupled plasma (ICP) analysis. After digestion samples were analyzed for Cs 

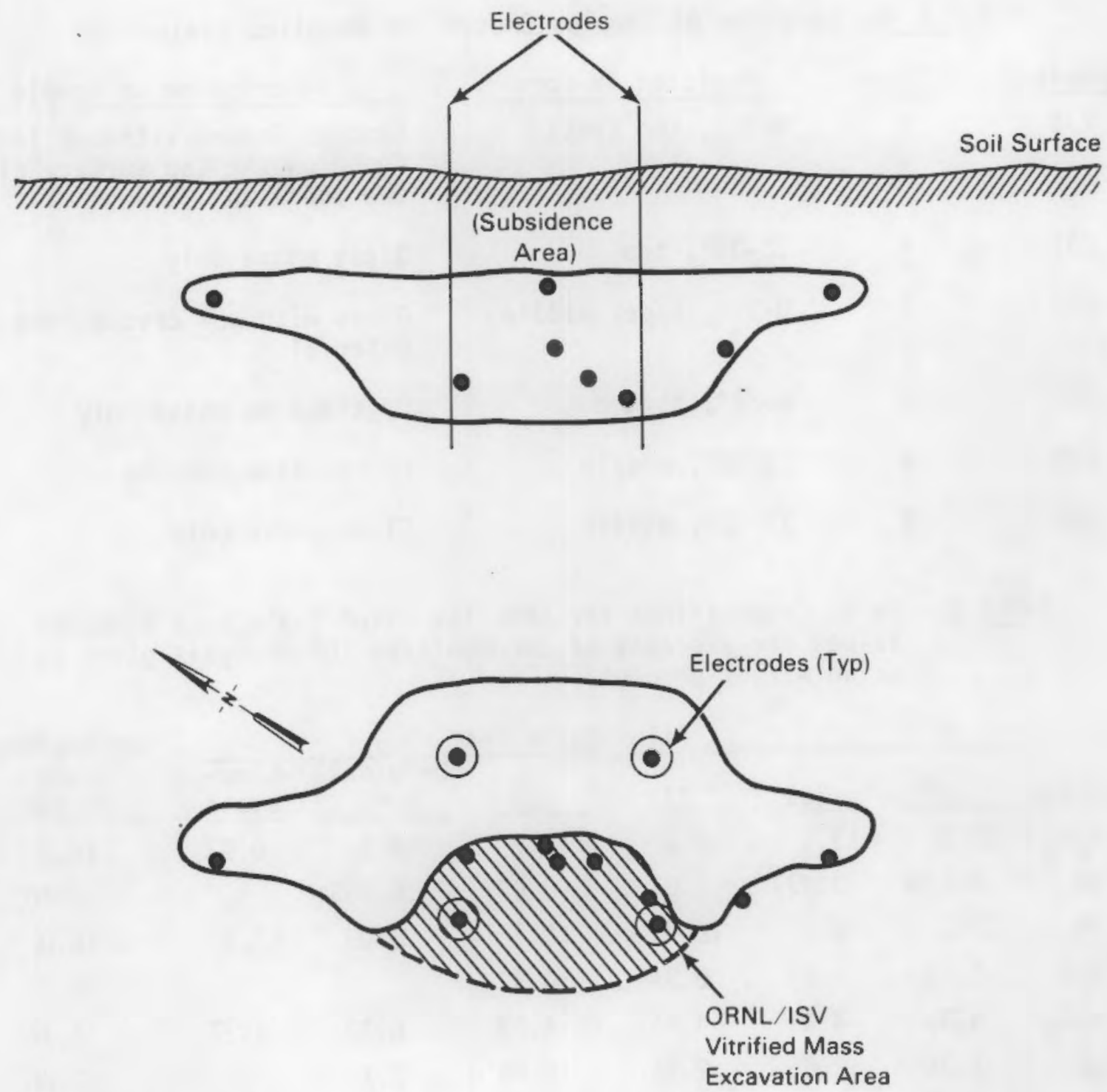

FIGURE 22. Position of Grab Samples Taken from the ISV Monolith (Samples Obtained after Excavation)

by atomic adsorption (AA). The oxide compositions of the four samples are presented in Table 5, along with the compositions of the original soil and limestone from the pilot-scale test area. A reference analysis from the engineering-scale test is also provided in Table 5. The composition of all the samples, both crystalline and glass phases, was essentially equal, 
TABLE 4. Location of Samples Chosen for Detailed Evaluation

\begin{tabular}{|c|c|c|c|}
\hline Sample \# & Core & Position in Core & Description of Sample \\
\hline 230 & 3 & $0-37^{\prime \prime}$, top crust & $\begin{array}{l}\text { Frothy, foamed vitreous layer } \\
\text { found on the top surface of } \\
\text { the monolith }\end{array}$ \\
\hline 231 & 4 & 13-31", top & Glass phase only \\
\hline 232 & 3 & $0-37 "$, upper middle & $\begin{array}{l}\text { Glass with } \approx 5 \% \text { crystalline } \\
\text { material }\end{array}$ \\
\hline 233 & 3 & $0-37 "$, bottom & Crystalline phase only \\
\hline 236 & 3 & 37-52", middle & Crystalline nodules \\
\hline 240 & 3 & 37-52', middle & Glass phase only \\
\hline
\end{tabular}

IABLE 5. Oxide Compositions for ORNL ISV Pilot-Scale Test Samples. Values are averages of unnormalized ICP analysis given as oxide weight-percent

\begin{tabular}{|c|c|c|c|c|c|c|c|}
\hline \multirow[b]{2}{*}{ Oxides } & \multicolumn{6}{|c|}{ Pilot-Scale Test } & \multirow{2}{*}{$\begin{array}{l}\text { Engineering- } \\
\text { Scale } \\
\text { Product } \\
\end{array}$} \\
\hline & 230 & 231 & 232 & 233 & $\begin{array}{c}\text { Original } \\
\text { soil } \\
\end{array}$ & $\begin{array}{l}\text { Lime- } \\
\text { stone }\end{array}$ & \\
\hline $\mathrm{Al}_{2} \mathrm{O}_{3}$ & 12.8 & 13.1 & 13.2 & 13.2 & 18.3 & 0.97 & 14.7 \\
\hline $\mathrm{BaO}$ & 0.074 & 0.077 & 0.078 & 0.077 & 0.063 & & 0.10 \\
\hline $\mathrm{CaO}$ & 17.2 & 18.6 & 18.7 & 18.7 & 3.09 & 87.3 & 15.0 \\
\hline $\mathrm{Cs}_{2}{ }^{\mathrm{O}}$ & 0.33 & 0.34 & 0.34 & 0.37 & & & 1.35 \\
\hline $\mathrm{Fe}_{2} \mathrm{O}_{3}$ & 4.30 & 4.41 & 4.46 & 4.52 & 6.32 & 1.37 & 4.14 \\
\hline $\mathrm{K}_{2} \mathrm{O}$ & 2.36 & 2.66 & 2.34 & 2.86 & 2.7 & & 2.28 \\
\hline $\mathrm{MgO}$ & 2.02 & 2.15 & 2.16 & 2.16 & 1.83 & 6.8 & 10.9 \\
\hline $\mathrm{MnO}_{2}$ & 0.14 & 0.14 & 0.14 & 0.15 & 0.12 & 0.39 & 0.14 \\
\hline $\mathrm{Na}_{2}{ }^{\mathrm{O}}$ & 1.50 & 1.38 & 1.47 & 1.74 & 0.77 & 0.65 & 0.93 \\
\hline $\mathrm{SiO}_{2}$ & 51.8 & 51.5 & 52.0 & 52.4 & 63.1 & 2.95 & 45.4 \\
\hline Sro & 1.30 & 1.40 & 1.40 & 1.39 & 0.13 & 0.05 & 4.17 \\
\hline $\mathrm{TiO}_{2}$ & 0.58 & 0.60 & 0.60 & 0.60 & 0.83 & & 0.64 \\
\hline $\mathrm{ZrO}_{2}$ & 0.029 & 0.043 & 0.035 & 0.046 & & & 0.035 \\
\hline Total & 94.5 & 96.2 & 96.9 & 98.2 & 92.3 & 100.5 & 99.8 \\
\hline
\end{tabular}


indicating that the monolith was at one time a relatively homogeneous melt and the gray crystalline material resulted from devitrification of the glass upon cooling. This hypothesis is supported by the increased amount of crystalline phase near the center of the monolith where the cooling rate would have been the slowest. Cesium and strontium levels in all samples, both glass and crystalline rock, were essentially the same--0.35 wt\%. $\mathrm{Cs}_{2} \mathrm{O}$ and $1.4 \mathrm{wt} \% \mathrm{SrO}$ as analyzed by ICP/AA.

To evaluate the distribution of $\mathrm{Cs}$ and $\mathrm{Sr}$ throughout the monolith, all the samples were semi-quantitatively analyzed by XRF for Cs and Sr. Spiked standards analyzed with the samples indicated levels of approximately 0.3 to $0.5 \mathrm{wt}_{\%} \mathrm{Cs}_{2} \mathrm{O}$ and $1.5 \mathrm{wt} \% \mathrm{SrO}$ in the ISV monolith, confirming the values obtained from ICP/AA analysis. The XRF results indicated that the $\mathrm{Sr}$ was very uniformly distributed throughout the monolith. XRF results for Cs varied by as much as $50 \%$ between the cores, but generally Cs was evenly dispersed throughout the monolith. The variations in Cs may have been due to the low level of $C_{s}$ in the product and analytical uncertainties. Little variation was observed vertically in any of the cores. The grab samples taken from each end of the monolith (see Figure 22) contained the same levels of both $\mathrm{Cs}$ and $\mathrm{Sr}$ as did the core samples from the middle.

The very bottom samples of several cores were unreacted soil, which revealed no detectable levels of $C s$ and $S r$ (same as for the reference soil and limestone samples). This would indicate that the ISV process contains the $\mathrm{Cs}$ and $\mathrm{Sr}$ within the vitrified mass and does not induce any migration of these elements down into the nearby soil. However, in one sample near the bottom of core 3, the Sr level was observed to reach background levels before the Cs level. This sample was material that had sintered and only partially melted. The unreacted soil samples taken just below the partially melted samples had only background levels of $\mathrm{Cs}$ and $\mathrm{Sr}$. The greater solubility of Cs compounds as compared to $\mathrm{Sr}$ could have allowed the $\mathrm{Cs}$ to be washed farther into the soil from the chemical addition before the test or from the core drilling after the test.

To determine the soil-to-limestone ratio of the vitrified mass, five major elements were identified from the mass analysis. The five elements were $\mathrm{SiO}_{2}, \mathrm{MgO}, \mathrm{Fe}_{2} \mathrm{O}_{3}, \mathrm{CaO}$, and $\mathrm{Al}_{2} \mathrm{O}_{3}$. Examination of the concentrations of 
these elements revealed that weight percent concentration of soil and limestone in the pilot-scale test are $20 \%$ limestone and $80 \%$ soil (see Appendix A for calculations.)

\subsubsection{Phase Behavior}

The structure of the waste form was evaluated by $x$-ray diffraction (XRD) and scanning electron microscopy with energy dispersive analysis by $\mathrm{x}$-ray (SEM/EDAX).

The vitreous samples submitted for XRD analysis exhibited no peaks, as expected. All the crystalline samples exhibited the same XRD pattern as shown in Figure 23. This pattern was quite complex and was the sum of more than one crystalline phase. In addition, substitutions of minor elements into the crystalline phases have likely offset the peaks, making precise identification difficult. However, it appears that the crystalline material consists predominately of anorthite (feldspar, $\mathrm{CaO}-\mathrm{Al}_{2} \mathrm{O}_{3}-\mathrm{SiO}_{2}$ ) and a wollastonite-like phase $\left(\mathrm{CaO}-\mathrm{SiO}_{2}\right)$, which is consistent with the phase dia-

gram of the $\mathrm{CaO}-\mathrm{Al}_{2} \mathrm{O}_{3}-\mathrm{SiO}_{2}$ system (Levin, Robins and McMurdie 1964). The XRD patterns for anorthite and a wollastonite are also presented in Figure 23 for comparison.

SEM/EDAX was conducted on thin sections of the four major samples to identify the different phases present. Thin sections of the glass samples found the glass to be homogeneous, with no detectable non-vitreous phases. The frothy glass layer found on the top surface of the monolith was also observed to be vitreous. X-ray mapping of $C_{s}$ in the glass samples found the Cs did not segregate and was uniformly dispersed throughout the glass. Because the levels of $C s$ in the samples were near the detection limits, the $x$-ray mapping can only indicate that no concentrations of Cs occurred. X-ray mapping of $\mathrm{Sr}$ was not possible due to overlap of the $\mathrm{Sr}$ peak by a very strong silicon peak.

The samples consisting of gray crystalline material were observed to be similar in morphology. A typical cross section is presented in Figure 24. The microstructure is represented by alternate layers of the three crystalline phases (lamellar) typically found when an eutectic composition cools. 


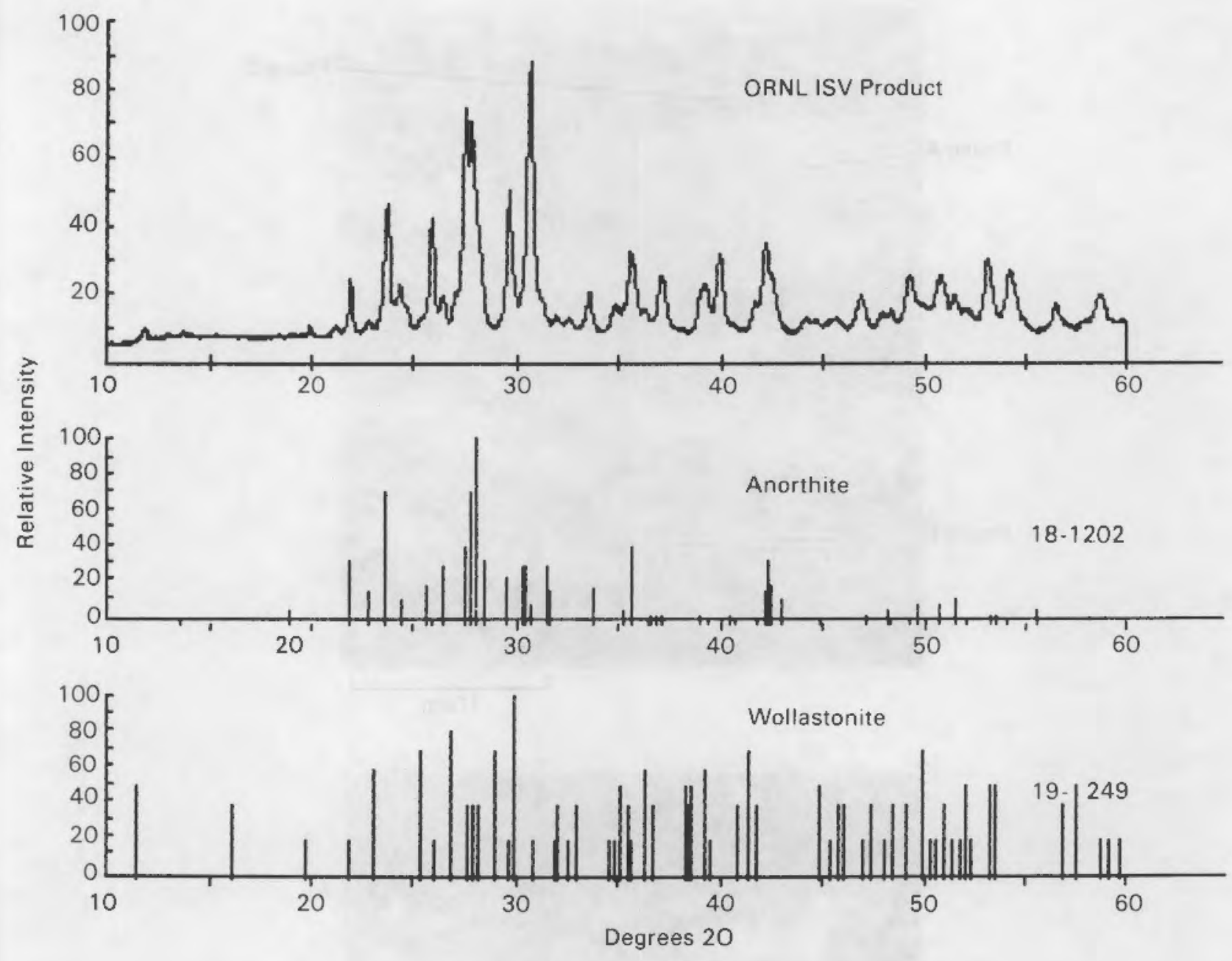

FIGURE 23. X-Ray Diffractometry Results of Gray Crystalline Material from Pilot-Scale ORNL ISV Test

$\mathrm{SiO}_{2}, \mathrm{CaO}$, and $\mathrm{Al}_{2} \mathrm{O}_{3}$ are the major components of ISV product. If only these three components are considered, the normalized composition of the ORNL ISV product is $62 \mathrm{wt} \% \mathrm{SiO}_{2}, 22.2 \mathrm{wt} \% \mathrm{CaO}$, and $15.7 \mathrm{wt} \% \mathrm{Al}_{2} \mathrm{O}_{3}$. This normalized composition was very near a low melting eutectic and may account for the microstructure of the crystalline phase (0sborn and Muan 1960). A cross section of one of the gray crystalline nodules found the crystal size to decrease from approximately $5 \mu \mathrm{m}$ thick at the center to less than $0.5 \mu \mathrm{m}$ at the outer surface of the nodule. 


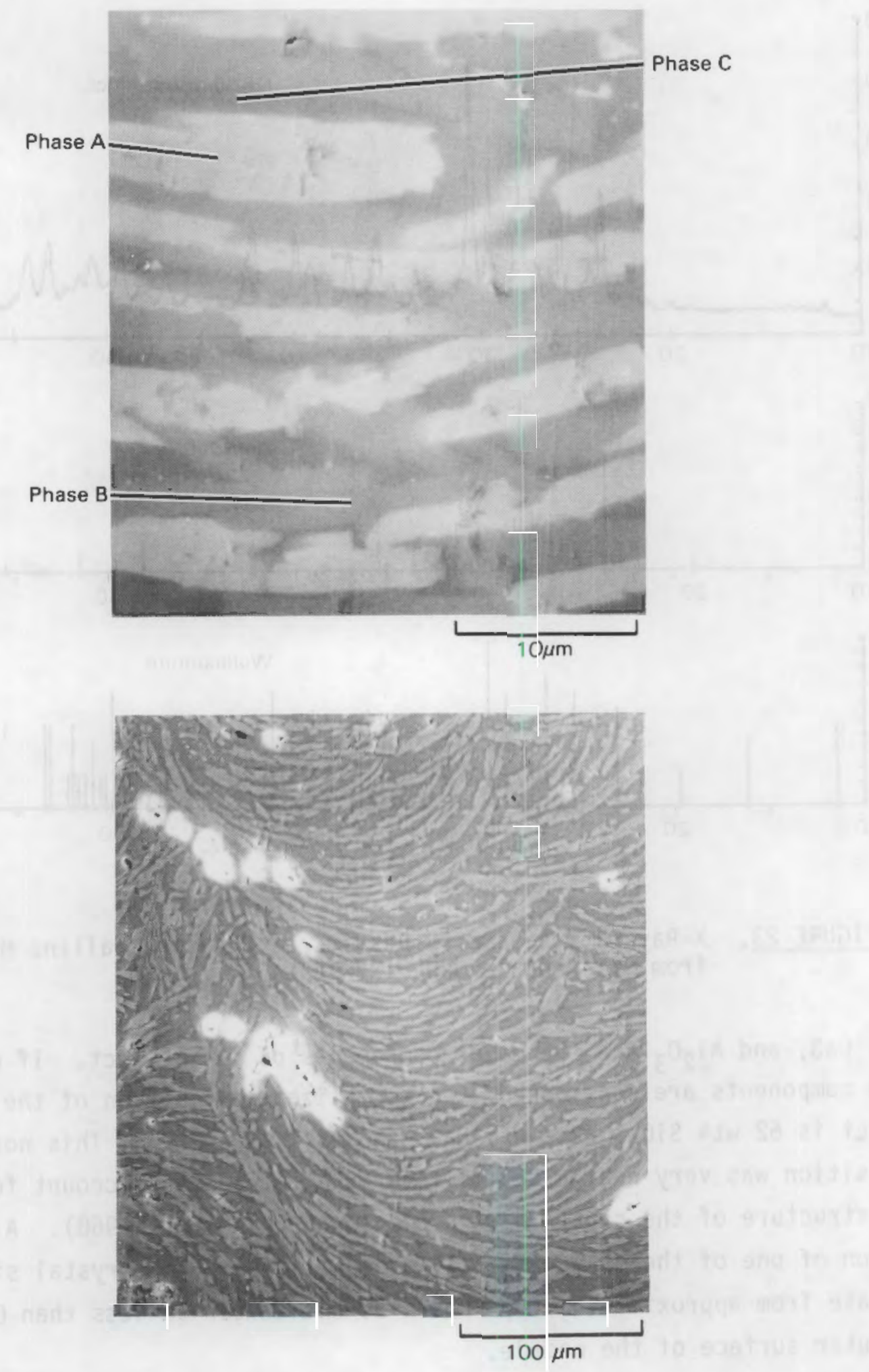

FIGURE 24. Typical Microstructure of Gray Crystalline Material from Pilot-Scale ORNL ISV Test 
The EDAX scans of the three phases are presented in Figures 25 through 27. The lighter phase (see Figure 24 and 25, phase A) had approximately equal amounts of $\mathrm{Ca}$ and $\mathrm{Si}$ with some $\mathrm{Mg}$ and $\mathrm{Fe}$ present, but little $\mathrm{Al}$ or $\mathrm{K}$. This phase is probably pseudowollastonite $\left(\mathrm{CaO}-\mathrm{SiO}_{2}\right)$.

The two darker phases shown previously (see Figure 24) have lower $\mathrm{Ca} / \mathrm{Si}$ ratios than the pseudowollastonite phase but increased amounts of $\mathrm{Al}$ and $\mathrm{K}$. Both darker phases had feldspar-type compositions. The lighter of the darker phases is probably a solid-solution of an anorthite phase (see Figure 24 and 26 , phase $B$ ). The darker phase was similar to the anorthite phase but with increased amounts of $\mathrm{K}$ and $\mathrm{Fe}$, and reduced amounts of $\mathrm{Al}$ and $\mathrm{Na}$ (see Figure 24 and 27 , phase $\mathrm{C}$ ).

$X$-ray mapping of $C s$ in the gray crystalline phase indicated that even after devitrification, the $C s$ did not concentrate significantly in any one phase. Figure 28 shows an area of crystalline product and the $x$-ray mapping of the Cs over the same area. The Cs show no segregation within any of the phases present.

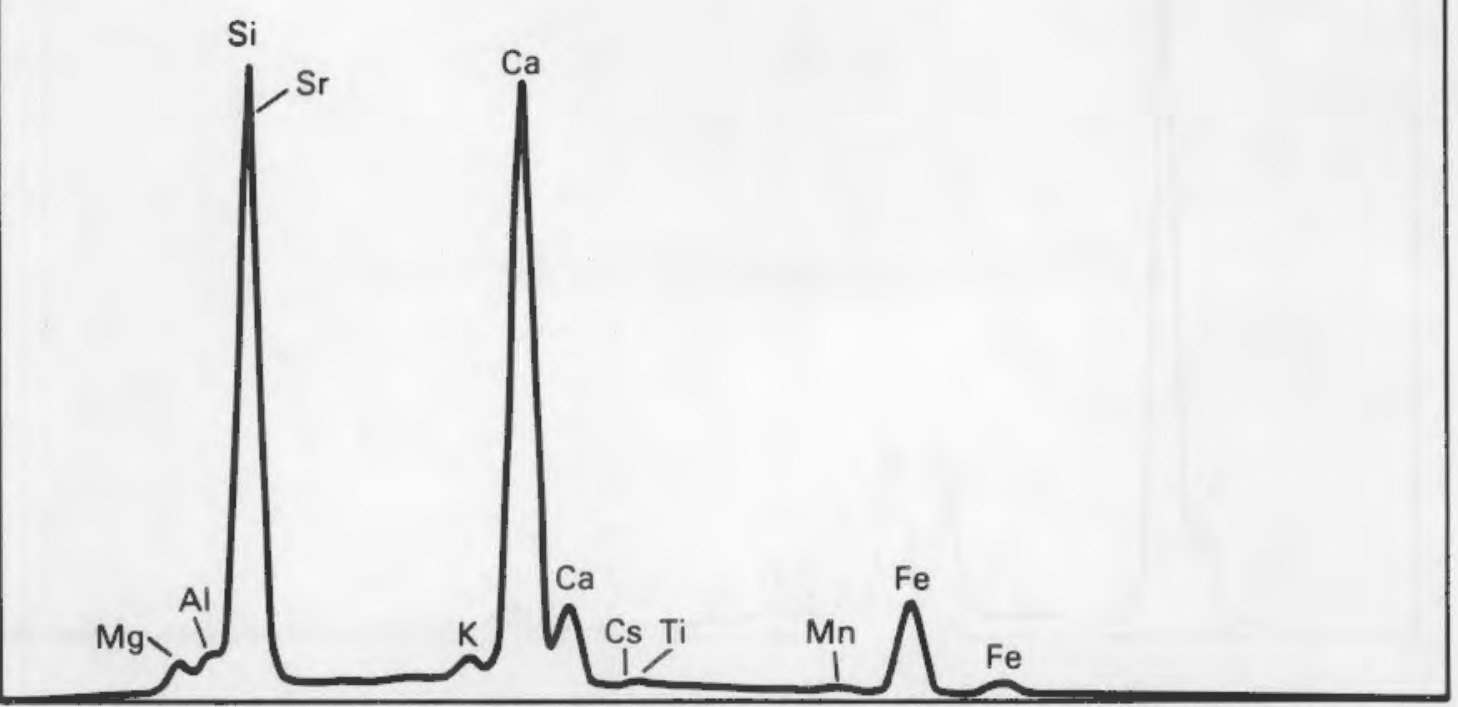

FIGURE 25. EDAX Spectra of Phases A in Figure 24 


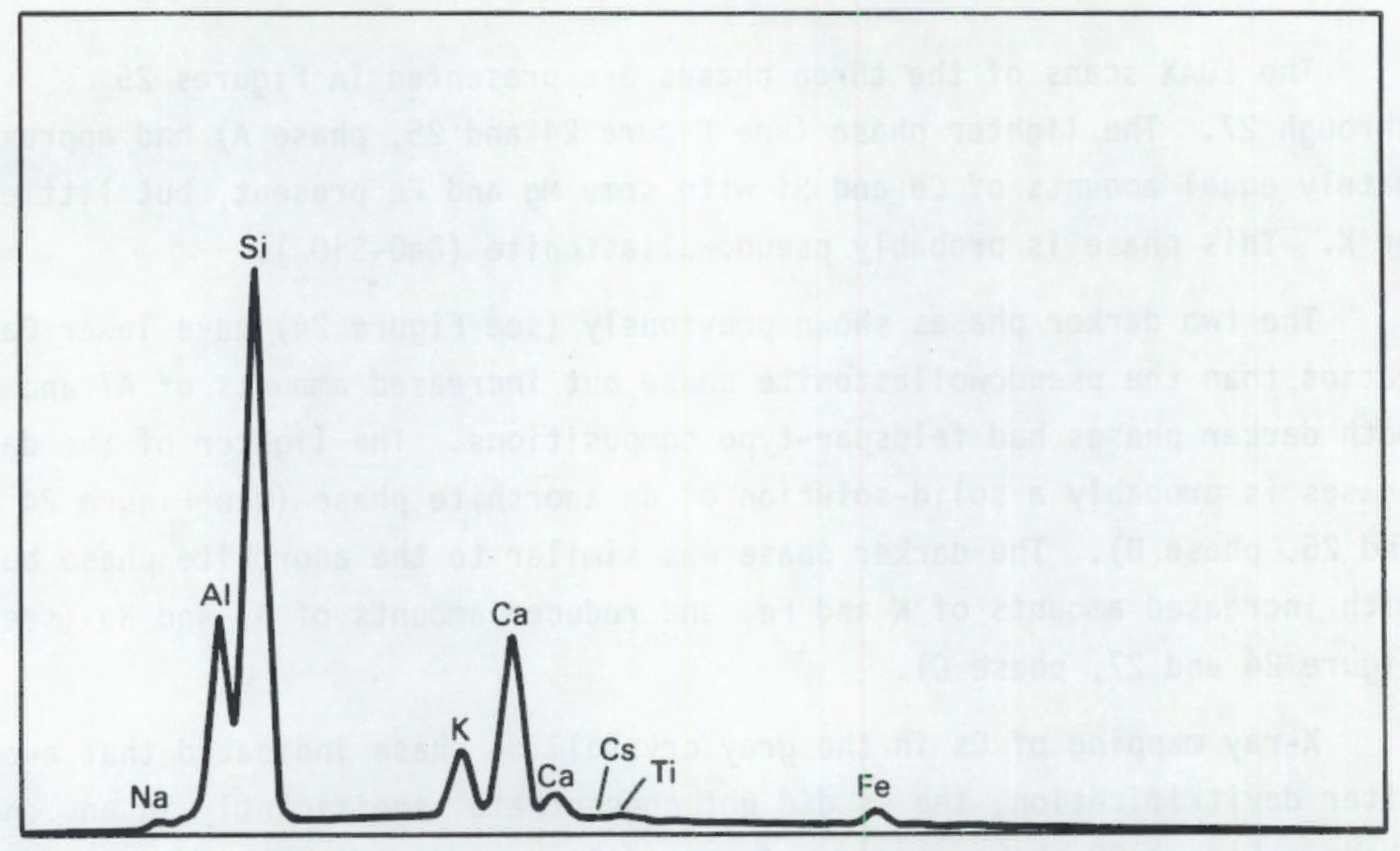

FIGURE 26. EDAX Spectra of Phases B in Figure 24

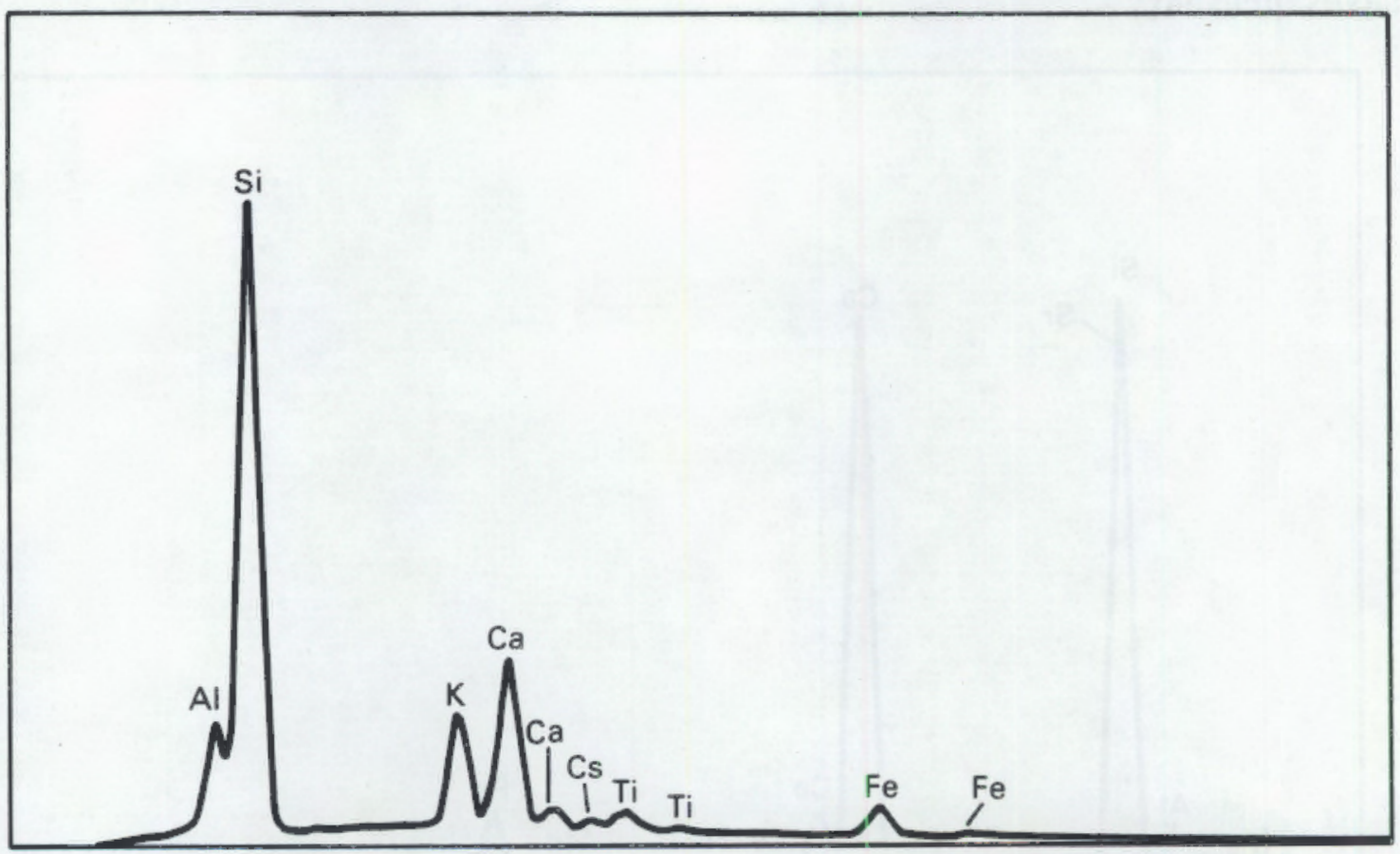

FIGURE 27. EDAX Spectra of Phases $C$ in Figure 24 

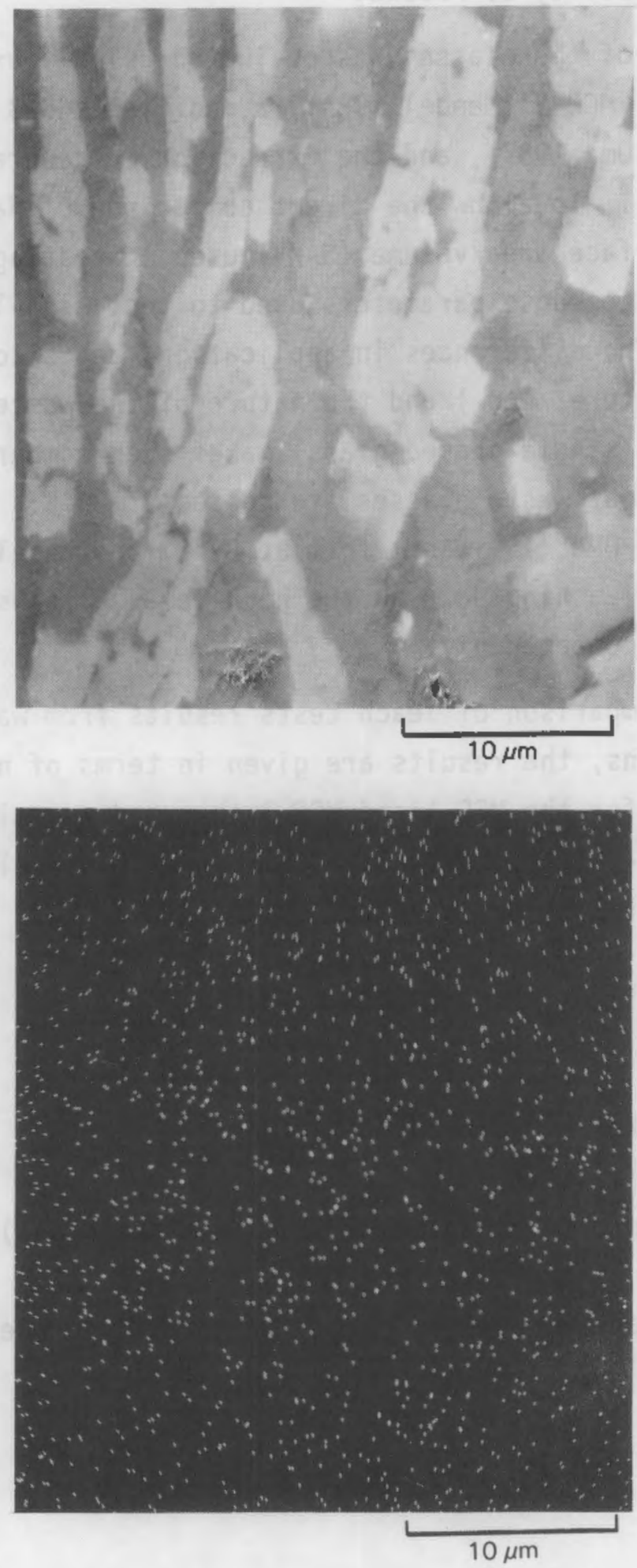

FIGURE 28. X-Ray Cesium Mapping of Typical Microstructure of Gray Crystalline Material from Pilot-Scale ORNL ISV Test 


\subsubsection{Chemical Durability of Product}

The durability of the glasses was evaluated using four types of tests: MCC-1 (Mendel 1984), MCC-3 (Mendel 1984), a modified MCC-3 (MCC-3mod; Bunnell, Maupin and Oma 1987), and the Extraction Procedure (EP) toxicity test (U.S. EPA 1986). To allow the direct comparison of data, the leachate, temperature, and surface area/volume $(\mathrm{SA} / \mathrm{V})$ used in testing the ISV waste form were identical to those parameters used to test high-level nuclear borosilicate glasses. The differences in application (repository conditions, groundwater, temperature, etc.) and the nature of the waste form (multiphased ceramic glass versus single-phased glass) makes such comparison difficult. Most high-level nuclear waste glasses are tested at $90^{\circ} \mathrm{C}$. By conducting the leach testing of the ORNL ISV waste form at $90^{\circ} \mathrm{C}$, the results can be compared to the data base of leaching data on the high-level glasses. Leachants were analyzed for cation content only.

To allow the comparison of leach tests results from waste forms with different compositions, the results are given in terms of normalized elemental mass release for the MCC-1 and MCC-3 test and normalized concentration for the modified MCC-3 test. Normalized elemental mass releases were calculated with the following equation:

$$
N R_{i}=m_{i} /\left(F_{i} \times S A\right)
$$

where $N R_{j}=$ normalized mass release of element $i\left(g / \mathrm{m}^{2}\right)$

$$
\begin{aligned}
& m_{i}=\text { mass of element } i \text { in leachate }(g) \\
& F_{i}=\text { fraction of element } i \text { in glass (dimensionless) } \\
& S A=\text { surface area of monolith or powder }\left(\mathrm{m}^{2}\right)
\end{aligned}
$$

The following equation was used to calculate normalized elemental concentrations:

$$
N C_{i}=C_{i} /\left(F_{i}\right)
$$


where $N C_{i}=$ normalized concentration of element $i\left(\mathrm{~g} / \mathrm{m}^{3}\right)$

$c_{i}=$ concentration of element $i$ in leachate $\left(\mathrm{g} / \mathrm{m}^{3}\right)$

$F_{i}=$ fraction of element $i$ in glass (dimensionless)

\subsubsection{MCC-1 Tests}

The MCC-1 static leach test (Mendel 1984) measures the elemental mass loss of a sample of glass as a function of time. For this type of test a glass monolith is suspended within a sealed Teflon ${ }^{\mathrm{N}}$ container. The surfacearea-to-volume ratio (surface area of sample/volume of leachant, SA/V) is selected, nominally $10 \mathrm{M}^{-1}$. The leachant can be a synthetic silicate ground water, a synthetic brine, or reagent water. The sealed container is maintained at $90^{\circ} \mathrm{C}$ for $3,7,14$, or 28 days. The test results are based on leachate ICP analysis (AA for Cs) from which the total concentrations of materials removed from the sample are determined. For this evaluation, testing was conducted with an SA $/ V$ of $10 \mathrm{~m}^{-1}$ in deionized water (DIW) at $90^{\circ} \mathrm{C}$ for 28 days.

Because the MCC-1 procedure requires a small monolith of sample, test samples consisted of only the glass or crystalline phase. Testing was conducted on sample numbers $230,231,232$ (glass phase only), and 233 (crystalline phase). The results from the $M C C-1$ leaching tests are presented in Table 6. Leaching data from two high-level nuclear waste glasses are also presented for comparison. Raw ICP data for MCC-1 are presented in Appendix D.

For the glass samples $(230,231$, and 232) normalized releases for each element did not vary significantly, suggesting that the dissolution of the waste form is congruent. The normalized releases for the crystalline samples varied slightly, indicating that some incongruent dissolution occurred. However, the crystalline phase (sample 233) appears to be more durable than the glass phase (samples 230,231 , or 232 ), as the normalized releases from the

Tu Teflon is a tradename of the E. I. du Pont de Nemours and Company. 
TABLE 6. Comparison of Normalized Release from MCC-1 Leach Testing for ORNL Pilot-Scale ISV Products and Some High-Level Nuclear Waste Glasses (a) Normalized Elemental Release $\left(\mathrm{g} / \mathrm{m}^{2}\right)$

\begin{tabular}{|c|c|c|c|c|c|c|}
\hline Element & 230 & 231 & 232 & 233 & $76-68^{(b)}$ & $\mathrm{SRL}_{165^{(\mathrm{c})}}$ \\
\hline Al & 5.9 & 6.0 & 5.6 & 2.8 & -- & 12 \\
\hline $\mathrm{Ca}$ & 6.9 & 6.5 & 6.3 & 3.8 & 3.0 & -- \\
\hline Si & 6.3 & 6.5 & 6.2 & 4.8 & 26 & 15 \\
\hline $\mathrm{Sr}$ & 7.5 & 7.2 & 6.9 & 1.7 & 3.8 & 1.7 \\
\hline Cs & 9.0 & 9.0 & 8.7 & 8.5 & 14.7 & 18 \\
\hline$(\mathrm{pH})$ & (9.3) & $(9.2)$ & (9.1) & $(9.1)$ & -- & -- \\
\hline
\end{tabular}

(a) Conditions: MCC -1 in DIW, 28 days, $S A / V=10^{-1}, 90^{\circ} \mathrm{C}$.

(b) Kindle, C. H. and M. R. Kreiter. 1987. Comprehensive Data Base of High-Level Nuclear Waste Glasses - September 1987 Status Report. Volume 1 - Discussion and Glass Durability Data. PNL-6353 Vol 1, Pacific Northwest Laboratory, Richland, Washington.

(c) Chandler, G. T., G. G. Wicks, and R. M. Wallace. 1984. Chemical Durability of SRP Waste Glass - Saturation Effects and Influence of SA/V. DP-MS-84-37, E. I. du Pont de Nemours \& Co., Savannah River Plant, Aiken, South Carolina.

crystalline sample were lower than those of the glass samples. The normalized releases for the ISV product were very comparable to those of the highlevel nuclear waste glasses.

\subsubsection{MCC-3 Tests}

The MCC-3 agitated powder leach test (Mendel 1984) is very similar to the MCC-1 test procedure, with two exceptions: the glass is in a powdered form, and glass powder and leachant are agitated by rotating the Teflon container in which the sample is suspended. The elemental leachate concentrations from $M C C-3$ tests are estimated to be representative of long-term extrapolation of MCC-1 test results. The MCC-3 tests also define maximum upper concentration limits under closed system static conditions. These objectives can be achieved more rapidly in the MCC-3 test because higher surface-area-to-volume ratios are used than those used for the MCC-1 tests. 
For this evaluation, tests were conducted with an SA/V of $2000 \mathrm{~m}^{-1}$ in DIW at $90^{\circ} \mathrm{C}$ for 28 days. Minus 100 mesh +200 mesh glass powder was used for all tests: Because of the higher SA/V used in the MCC-3 testing compared to that used for $M C C-1$ testing $\left(2000 \mathrm{~m}^{-1}\right.$ and $10 \mathrm{~m}^{-1}$, respectively), the leachants in the MCC-3 tests became saturated much sooner than the leachants in the MCC-1 tests. This saturation slows the dissolution process. Therefore, direct comparison of normalized release values from the MCC -1 and MCC- 3 tests are not appropriate.

Because a powdered sample is used for the MCC-3 tests, a combination of glass and gray crystalline material was also tested. A 50/50 wt\% mixture of sample 236 (crystalline nodules) and 240 (glass) was used (see Table 4). All tests were run in duplicate.

The results from the MCC-3 leach tests are presented in Tables 7 and 8 . MCC -3 leachants were filtered through $0.45-\mu \mathrm{m}$ filters, then 18-angstrom filters, to determine the amount of colloidal material in the leachant. ICP results, standard deviations, and percent relative standard deviations are presented in Appendix D. The same trends observed in the MCC-1 test results

TABLE 7. Comparison of Average Normalized Releases from MCC -3 Leach Testing: D.45- $\mathrm{mm}$ Filtrate for ORNL Pilot-Scale ISV Products and Some High-Level Nuclear Waste Glasses(a)

\begin{tabular}{|c|c|c|c|c|c|c|}
\hline \multirow[b]{2}{*}{ Element } & \multicolumn{6}{|c|}{$0.45-\mu \mathrm{m}$ Normalized Elemental Release $\left(\mathrm{g} / \mathrm{m}^{2}\right)$} \\
\hline & $230 P$ & $231 P$ & $232 P$ & $233 P$ & $236 / 240$ & SRL165 \\
\hline Al & 0.019 & 0.020 & 0.019 & 0.014 & 0.018 & 0.27 \\
\hline $\mathrm{Ca}$ & 0.058 & 0.048 & 0.041 & 0.032 & 0.037 & 0.07 \\
\hline Si & 0.039 & 0.039 & 0.038 & 0.040 & 0.039 & 0.32 \\
\hline Sr & 0.046 & 0.039 & 0.036 & 0.020 & 0.026 & 0.05 \\
\hline Cs & 0.097 & 0.073 & 0.072 & 0.147 & 0.143 & -- \\
\hline$(\mathrm{pH})$ & $(9.4)$ & $(9.4)$ & $(9.6)$ & $(9.5)$ & $(9.5)$ & -- \\
\hline
\end{tabular}

(a) Conditions: $M C C-3$ in DIW, 28 days, $S A / V=2000 \mathrm{~m}^{-1}, 90^{\circ} \mathrm{C}$,
2 replicates. 
TABLE 8. Comparison of Average Normalized Releases from MCC-3 Leach Testing: 18-Angstrom Filtrate for ORNL. Pilot-Scale ISV

Products and Some High-Level Nuclear Waste Glasses(a)

\begin{tabular}{|c|c|c|c|c|c|c|}
\hline \multirow[b]{2}{*}{ Element } & \multicolumn{6}{|c|}{ 18A Normalized Elemental Release $\left(\mathrm{g} / \mathrm{m}^{2}\right)$} \\
\hline & $230 \mathrm{P}$ & $231 \mathrm{P}$ & $232 P$ & $233 P$ & $\underline{236 / 240}$ & $\underline{\text { SRL165 }}$ \\
\hline A1 & 0.018 & 0.019 & 0.018 & 0.013 & 0.017 & 0.10 \\
\hline $\mathrm{Ca}$ & 0.054 & 0.039 & 0.038 & 0.029 & 0.033 & 0.02 \\
\hline Si & 0.038 & 0.038 & 0.037 & 0.039 & 0.038 & 0.26 \\
\hline $\mathrm{Sr}$ & 0.042 & 0.033 & 0.032 & 0.017 & 0.022 & $>0.01$ \\
\hline Cs & 0.085 & 0.070 & 0.070 & 0.140 & 0.123 & --- \\
\hline
\end{tabular}

(a) Conditions: MCC- 3 in DIW, 28 days, $S A / V=2000 \mathrm{~m}^{-1}, 90^{\circ} \mathrm{C}$, 2 replicates

were apparent in the MCC-3 test results. The releases from the combined glass-crystalline sample were between the glass-only and crystalline-only samples, suggesting that no interactions occurred during leaching. The waste form from the ISV test, both glass and crystalline, had releases approximately half to 10 times lower than those for the SRL-165.

\subsubsection{Modified MCC-3 Tests}

To assess the glass durability over a wider range of conditions, the modified MCC-3 leach tests (Bunnel1, Maupin, and Oma 1987) were conducted in the three regimes typically observed in glass dissolution: 1) the time the glass first contacts a leachate and the glass dissolution rate is uninhibited by any solubility effects (the initial or forward rate), 2) a transient regime where the increasing concentrations of dissolved glass components in the leachate slows the dissolution rate through solubility effects, and 3) a final constant dissolution rate where alteration processes (saturation) have reached a steady rate. Because the ISV waste form will be in a near-surface environment where water flow rates will probably be relatively high, saturation of the water probably will not occur and the forward rate of dissolution will be most important.

The modified MCC- 3 procedure was used to evaluate the relative chemical durability of various glass samples over a wide range of SA/V•time conditions, including the forward rate of dissolution. Testing was conducted at 
surface area/leachant volumes (SA/V) of 50,2000 , and $10000 \mathrm{~m}^{-1}$. To simulate high flow-rate conditions, a static dissolution test was conducted in which $1 \mathrm{~g}$ of $-100+200$ mesh glass powder was added to $400 \mathrm{~mL}$ of DIW and placed in a $90^{\circ} \mathrm{C}$ oven. This procedure provided the desired $S A / V$ ratio of $50 \mathrm{~m}^{-1}$. At specified time intervals, a $5-\mathrm{mL}$ sample of leachate will be removed and replaced with fresh DIW. Using this technique, multiple leachate samples were extracted from a single dissolution test. Six samples were taken from each SA/V test. The tests using SA/V of $2000 \mathrm{~m}^{-1}$ and $10000 \mathrm{~m}^{-1}$ were similarly conducted, with the amount of sample and OIW adjusted accordingly. For $2000 \mathrm{~m}^{-1}, 7 \mathrm{~g}$ of powder were added to $70 \mathrm{~mL}$ of DIW. For $10000 \mathrm{~m}^{-1}, 10 \mathrm{gr}$ powder were added to $20 \mathrm{~mL}$ of DIW. Minus $100+200$ mesh powder was used for all tests.

The modified MCC-3 test is also being used to evaluate obsidian, which is the natural analog to the ISV waste form. Comparing the release characteristics for the ORNL ISV waste form with those for obsidian may be helpful in qualifying the ISV waste form. The results from the natural analog tests will be available later this year.

The results from the modified MCC -3 tests are plotted as a $\log / \log$ plot of normalized elemental concentration as a function of (time-SA/V). Note that on a $\log / \log$ plot, lines having unit slope represent constant rate. The $Y$-intercept (at $\log (t i m e \cdot S A / V)=0)$ of a line having unit slope, and going through any point on the functional curve, will represent the average functional rate at that point. The results from the modified MCC-3 tests for each sample are presented in Figures 29 through 32 . The error bars (plotted only for $\mathrm{Si}$ ) in Figure 30 indicate \pm 2 standard deviations. In each plot, the normalized concentrations at low saturation (smaller values of [t•SA/V]) follow a unit slope. The intersection of that unit slope with the $Y$-intercept define the forward dissolution rate for each sample. Dissolution at the forward rate appears to be congruent. As $t \cdot S A / V$ increases, the dissolution rate begins to slow as solubility becomes a factor. As $t \cdot S A / V$ increase further, the elements with low solubilities begin to precipitate. This was the reason for the higher values of the more soluble Cs when compared to the other components plotted at higher t•SA/V's. ICP data and results for modified $M C C-3$ tests are presented in Appendix $D$. 


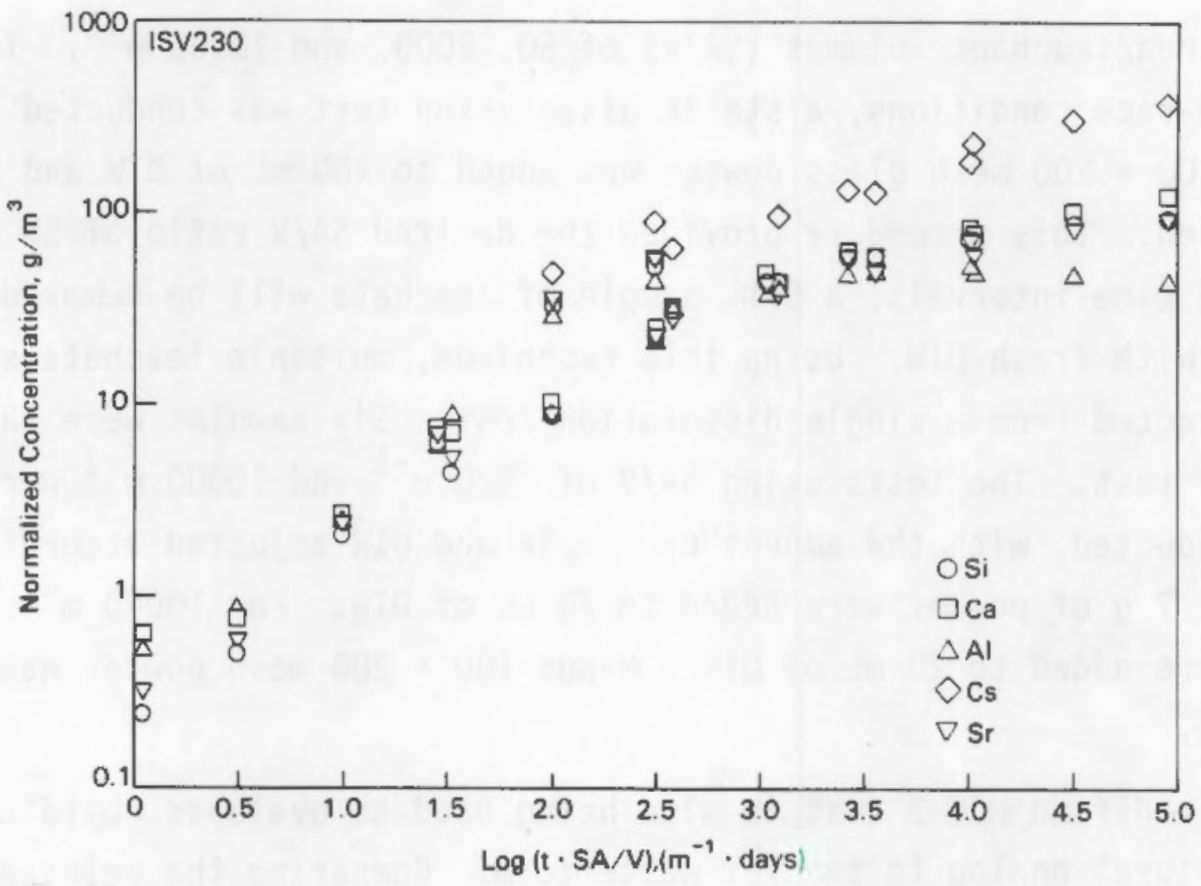

FIGURE 29. Normalized Elemental Concentrations (in leachate) Versus $(t \cdot S A / V)$ for ORNL Pilot-Scale ISV sample 230

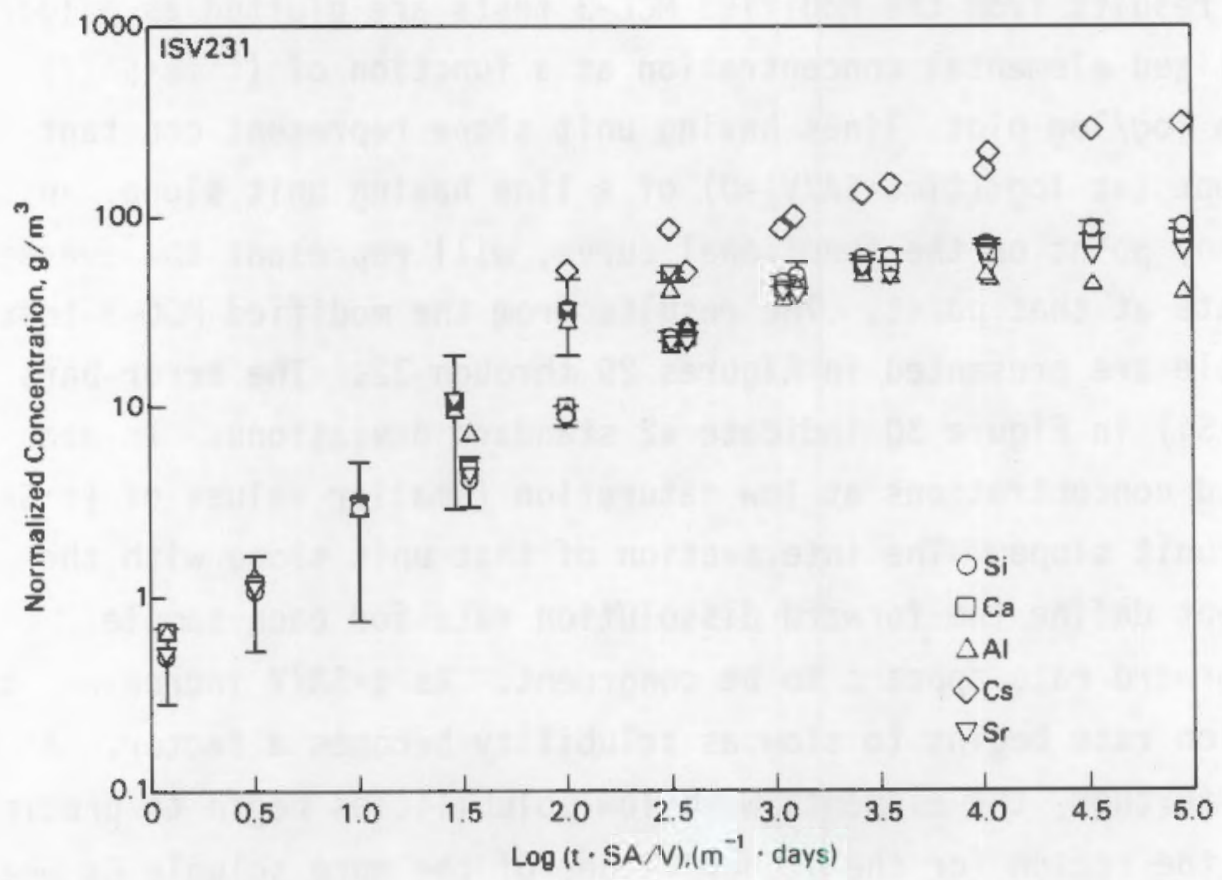

FIGURE 30. Average Normalized Elemental Concentrations (in leachate) Versus $(t \bullet S A / V)$ for ORNL Pilot-Scale ISV Sample 231 


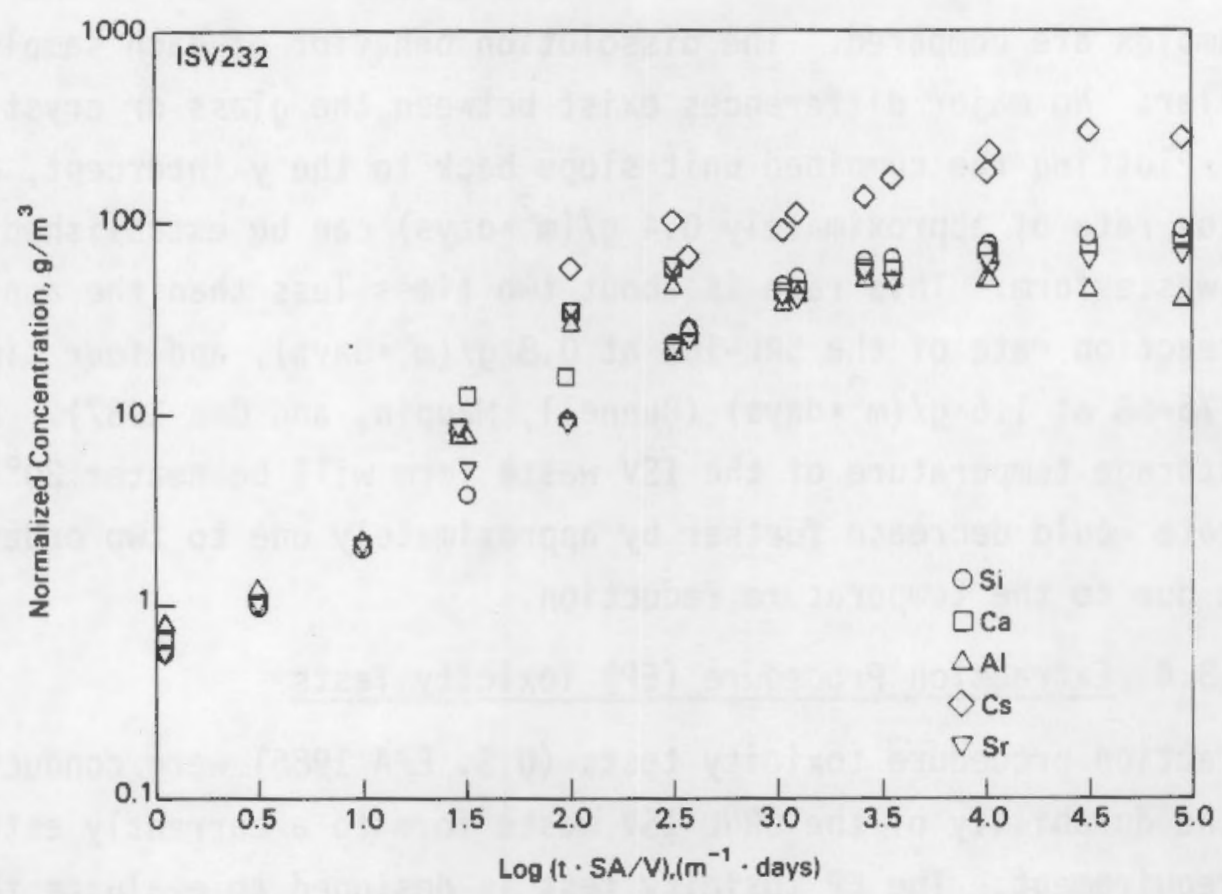

FIGURE 31. Normalized Elemental Concentrations (in leachate) Versus $(t \cdot S A / V)$ for ORNL Pilot-Scale ISV Sample 232

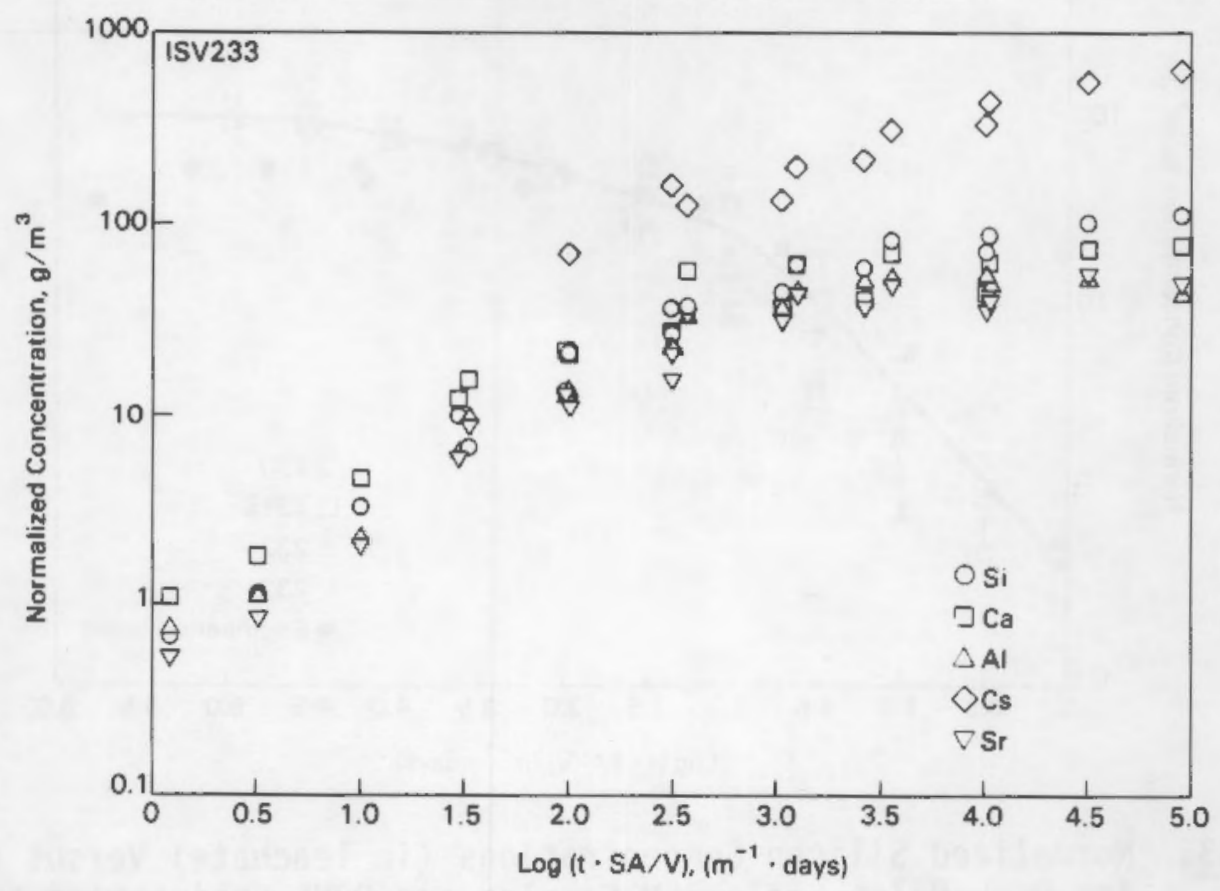

FIGURE 32. Normalized Elemental Concentrations (in leachate) Versus $(t \bullet S A / V)$ for ORNL Pilot-Scale ISV Sample 233 
In Figure 33, the normalized Si concentrations for each of the four tested samples are compared. The dissolution behavior of each sample was very similar. No major differences exist between the glass or crystalline samples. Plotting the combined unit slope back to the $y$-intercept, a forward dissolution rate of approximately $0.4 \mathrm{~g} /\left(\mathrm{m}^{2} \cdot\right.$ days) can be established for the ORNL ISV waste form. This rate is about two times less than the approximate forward reaction rate of the $S R L-165$ at $0.8 \mathrm{~g} /\left(\mathrm{m}^{2} \cdot\right.$ days $)$, and four times lower than PNL 76-68 at $1.6 \mathrm{~g} /\left(\mathrm{m}^{2} \cdot\right.$ days) (Bunnell, Maupin, and Oma 1987). Because ambient storage temperature of the ISV waste form will be nearer $20^{\circ} \mathrm{C}$, the forward rate would decrease further by approximately one to two orders of magnitude due to the temperature reduction.

\subsubsection{Extraction Procedure (EP) Toxicity Tests}

Extraction procedure toxicity tests (U.S. EPA 1986) were conducted to compare the durability of the ORNL ISV waste form to a currently established release requirement. The EP toxicity test is designed to evaluate the

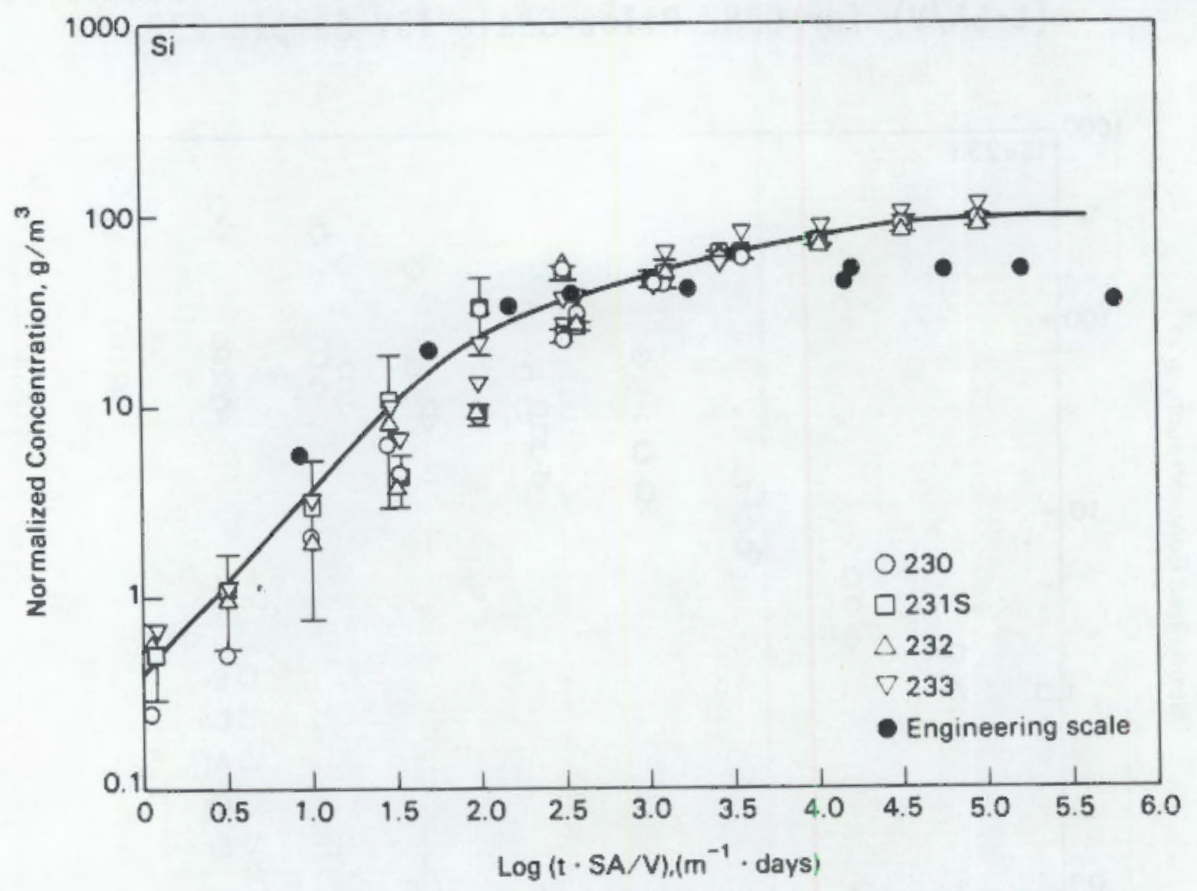

FIGURE 33. Normalized Silicon Concentrations (in leachate) Versus (t.SA/V) for ORNL Pilot-Scale ISV Samples and ORNL Engineering-Scale Sample 
extraction toxicity of a waste form. The testing consists of extracting $100 \mathrm{~g}$ of the waste form with $1600 \mathrm{~g}$ of DIW. Acetic acid is used to maintain the OIW at a pH of $5 \neq 0.2$. The duration of the EP toxicity test was 24 hours. The extract was then analyzed by ICP or AA ( $\mathrm{Hg}$ and $\mathrm{Ag}$ ). EP toxicity maximum concentration limits that have been established for some elements are presented in Table 9.

Barium is the only detectable element in the ORNL pilot-scale ISV product for which maximum concentrations limits have been set. The limit for barium is $100.0 \mathrm{mg} / \mathrm{L}$, and the highest concentration detected for any of the samples tested was $0.044 \mathrm{mg} / \mathrm{L}$. Unless the concentrations of any of the elements listed in Table 8 increase substantially in the ISV soil or limestone, the ISV waste form should easily meet any EP toxicity requirements.

TABLE 9. Results from EP Toxicity Testing of the Pilot-Scale ISV Test at ORNL

\begin{tabular}{|c|c|c|c|c|c|}
\hline Contaminant & 230 & $\begin{array}{c}\text { Sample } \\
231 \\
\end{array}$ & $\begin{array}{c}\text { umbers } \\
232\end{array}$ & 233 & $\begin{array}{c}\text { Maximum } \\
\text { Concentration Allowed } \\
(\mathrm{mg} / \mathrm{L}) \\
\end{array}$ \\
\hline Arsenic & $<1$ & $<1$ & $<1$ & $<1$ & 5.0 \\
\hline Barium & 0.015 & 0.012 & 0.016 & 0.044 & 100.0 \\
\hline Cadmium & $<0.005$ & $<0.005$ & $<0.005$ & $<0.005$ & 1.0 \\
\hline Chromium & $<0.02$ & $<0.02$ & $<0.02$ & $<0.02$ & 5.0 \\
\hline Lead & $<0.05$ & $<0.05$ & $<0.05$ & $<0.05$ & 5.0 \\
\hline Mercury & $<0.001$ & $<0.001$ & $<0.001$ & $<0.001$ & 0.2 \\
\hline Selenium & $<1$ & $<1$ & $<1$ & $<1$ & 1.9 \\
\hline Silver & $<0.1$ & $<0.1$ & $<0.1$ & $<0.1$ & 5.0 \\
\hline
\end{tabular}





\subsection{COMPARISON OF CESIUM RETENTION FOR ORNL AND HANFORD ISV GLASSES}

Engineering-scale ISV testing of ORNL and Hanford soils indicate that the retention of $\mathrm{CS}_{\mathrm{S}}$ in the ORNL ISV product was greater than in the Hanford ISV product (99.999\% compared to $99.0 \%$ ). The major difference in the ORNL and Hanford ISV soils and products was the large amount of dolomite vitrified with the ORNL soil. This difference not only resulted in a significant compositional difference, but also reduced the viscosity of the ORNL ISV melt compared to the Hanford ISV melt. Because of this reduction in viscosity, the operating temperatures were lower for the ORNL ISV process. This study evaluated whether or not the viscosity, and thus the operating temperature of the ISV process, was a significant factor in the observed difference in Cs retention and whether or not the composition of the ISV melt affects CS and/or Sr retention.

\subsection{TECHNICAL APPROACH}

To determine the CS and Sr retention in vitrified ORNL and Hanford ISV products, soil compositions from the two sites were melted after being doped with nonradioactive $\mathrm{Cs}$ and $\mathrm{Sr}$. Each glass was then held at the 100 poise temperatures (T10OP) of the ORNL and Hanford ISV glass to detemine the amount of $\mathrm{Cs}$ and $\mathrm{Sr}$ retention. The viscosity of the Hanford glass was reduced to that of the ORNL glass by the addition of different glass components, and the retention of $\mathrm{Cs}$ and $\mathrm{Sr}$ was determined in order to evaluate the effects of compositional differences.

Batches of ORNL (soil plus dolomite) and Hanford ISV products were melted after being doped with additional nonradioactive $\mathrm{Cs}$ and $\mathrm{Sr}$. The additional $\mathrm{Cs}$ and $\mathrm{Sr}$ were added to help exceed the detection limits of the analytical evaluations. Each melt was melted for 2 hours at their respective, approximate T100P and then air-quenched. The compositions of each batch were determined by ICP, XRF, and AA. The viscosity curve for each glass was then determined. The T100P for the ORNL ISV glass was $1324^{\circ} \mathrm{C}$ and for the Kanford ISV glass was $1665^{\circ} \mathrm{C}$. Table 10 summarizes the wt: $\mathrm{Cs}_{2} \mathrm{O}$ and Sro in each glass, plus the T100P that was used. 
TABLE 10. Sumnary of Glass Cs and Sr Concentrations and 100 Poise Temperatures

\begin{tabular}{|c|c|c|c|}
\hline Glass Product & $\mathrm{Cs}_{2} \mathrm{O} \mathrm{wt} \%$ & Sro wt: & T100P $\left({ }^{\circ} \mathrm{C}\right)$ \\
\hline ORNL ISV & 1.96 & 4.16 & 1324 \\
\hline Hanford ISV & 2.18 & 3.72 & 1665 \\
\hline Hanford ISV (CaO Adjust) & 1.95 & 3.64 & 1325 \\
\hline Hanford ISV ( $\mathrm{Na}_{2} \mathrm{O}$ Adjust) & 2.15 & 3.73 & 1325 \\
\hline
\end{tabular}

The elemental off-gas from the melt is a function of the volatility of the element and the mobility of the element within the melt, which is a function of the melt viscosity. As the temperature increases, the volatility increases and the viscosity decreases, both of which increase volatilization from the melt. To evaluate the effects of temperature on the retention of Cs and $\mathrm{Sr}$, both the ORNL and Hanford ISV glasses were held at $1300^{\circ} \mathrm{C}$ and $1650^{\circ} \mathrm{C}$ within a tube furnace with an H-Ar cover gas. The resulting off-gas was passed through two bubblers. The solutions within the bubblers were used to rinse out the furnace tube after the run to recover any deposited $\mathrm{Cs}$ and $\mathrm{Sr}$, concentrated, and analyzed. It is estimated that the test is sensitive to $99.99 \%$ retention.

To evaluate the effects from $C s$ and $S r$ composition on retention, the T100P of the Hanford soil was reduced to that of the ORNL soil $\left(1325^{\circ} \mathrm{C}\right)$ by the addition of $\mathrm{CaO}$ in one case and $\mathrm{Na}_{2} \mathrm{O}$ in another. The amount of $\mathrm{CaO}$ in the ISV product is the major difference between the two ISV product compositions. These two modified Hanford compositions were tested for $\mathrm{Cs}$ and $\mathrm{Sr}$ retention at approximately $1325^{\circ} \mathrm{C}$. The analyzed compositions for all the glass tested are show in Table 11.

\subsection{IEST EVALUATIONS}

A summary of the concentrations found in the scrub solutions is presented in Table 12. The retention of $\mathrm{Sr}$ was observed to be 100.008 and was unaffected by composition and melt temperatures. 1ncreasing the melt temperature of an ORNL ISV glass from its T100P of $1325^{\circ} \mathrm{C}$ to $1650^{\circ} \mathrm{C}$ ( $\mathrm{s} 3$ poise) increased the $\mathrm{Cs}$ concentration in the off-gas solutions approximately 

IABLE 11. Analyzed Compositions of the Glasses Used in the
Cesium Retention Study

\begin{tabular}{|c|c|c|c|c|}
\hline Oxide & $\begin{array}{l}\text { ORNL ISV } \\
\text { (Cs Spike) }\end{array}$ & $\begin{array}{l}\text { Hanford } \\
\text { ISV } \\
\text { (Cs Spike) }\end{array}$ & $\begin{array}{c}\text { Hanford } \\
\text { ISV } \\
\text { (CaO Adjusted) }\end{array}$ & $\begin{array}{c}\text { Hanford } \\
\text { ISV } \\
\text { ( } \mathrm{Na}_{2} \mathrm{O} \text { Adjusted) }\end{array}$ \\
\hline $\mathrm{Al}_{2} \mathrm{O}_{3}$ & 13.6 & 12.2 & 10.2 & 10.3 \\
\hline $\mathrm{B}_{2} \mathrm{O}_{3}$ & 0.16 & 0.09 & 0.08 & \\
\hline $\mathrm{BaO}$ & 0.10 & 0.12 & 0.11 & 0.11 \\
\hline $\mathrm{CaO}$ & 13.9 & 4.54 & 18.1 & 3.93 \\
\hline $\mathrm{Cr}_{2} \mathrm{O}_{3}$ & & & 0.08 & \\
\hline $\mathrm{Cs}_{2} \mathrm{O}$ & 1.96 & 2.18 & 1.95 & 2.15 \\
\hline $\mathrm{Fe}_{2} \mathrm{O}_{3}$ & 3.78 & 6.57 & 5.50 & 5.59 \\
\hline $\mathrm{K}_{2} \overline{0}$ & 3.2 & 1.9 & 1.5 & 0.9 \\
\hline $\mathrm{Li}_{2} \mathrm{O}$ & 0.08 & & 0.05 & 0.03 \\
\hline $\mathrm{MgO}$ & 10.1 & 2.21 & 1.92 & 1.83 \\
\hline $\mathrm{MnO}_{2}$ & 0.13 & 0.14 & 0.12 & 0.12 \\
\hline $\mathrm{Na}_{2} \mathrm{O}$ & 1.05 & 3.13 & 3.01 & 17.8 \\
\hline $\mathrm{NiO}$ & 0.04 & 0.05 & 0.25 & 0.04 \\
\hline $\mathrm{SiO}_{2}$ & 48.5 & 61.6 & 51.1 & 52.2 \\
\hline $\mathrm{SrO}^{-}$ & 4.16 & 3.72 & 3.64 & 3.73 \\
\hline $\mathrm{TiO}_{2}$ & 0.62 & 1.13 & 0.94 & 0.96 \\
\hline$v_{2} 03$ & & 0.03 & 0.02 & 0.02 \\
\hline $\mathrm{ZrO}_{2}$ & 0.03 & 0.04 & 0.02 & 0.03 \\
\hline Total & 101.4 & 99.7 & 98.6 & 99.7 \\
\hline
\end{tabular}

TABLE 12. Summary of Cesium Off-Gas and Retention Results

\begin{tabular}{|c|c|c|c|c|}
\hline Glass Product & $\begin{array}{c}\text { Test } \\
\text { Temperature }\end{array}$ & $\begin{array}{l}\text { Viscosity } \\
\text { Poise } \\
\end{array}$ & $\begin{array}{l}\text { Off-Gas Conc. } \\
\text { Cs }(\mu \mathrm{g} / \mathrm{ml})\end{array}$ & $\begin{array}{c}\text { Retention } \\
\text { (wt } \% \text { ) }\end{array}$ \\
\hline ORNL ISV & 1325 & 100 & 5.3 & 99.865 \\
\hline ORNL ISV & 1650 & 3 & 220 & 94.388 \\
\hline Hanford ISV & 1650 & 100 & 17.8 & 99.592 \\
\hline $\begin{array}{l}\text { Hanford ISV (CaO } \\
\text { Adjusted) }\end{array}$ & 1325 & 100 & 5.9 & 99.849 \\
\hline $\begin{array}{l}\text { Hanford ISV ( } \mathrm{Na}_{2} \mathrm{O} \\
\text { Adjusted) }\end{array}$ & 1325 & 100 & 12.8 & 99.702 \\
\hline
\end{tabular}


40 times. This increase was due to increased Cs vapor pressure and/or the decrease in melt viscosity due to the higher temperature. Further testing is required to determine if this increase in volatility is a linear function with temperature.

When the Hanford ISV glass was tested at its T100P of $1650^{\circ} \mathrm{C}$, the Cs release was three times that of the ORNL ISV glass at its I100P. Because the viscosities at the testing temperatures were the same, this difference must be due to the increased vapor pressure at $1650^{\circ} \mathrm{C}$ or the compositional differences in the two glasses. When the TlOOP of the Hanford ISV glass was reduced to that of the ORNL glass by the addition of CaO, the Cs releases were the same. This indicated that composition does have an effect on Cs retention but is small compared to temperature and viscosity effects.

When the viscosity of the Hanford glass was reduced with $\mathrm{Na}_{2} \mathrm{O}$ instead of $\mathrm{Ca0}$, the Cs release was a factor of two greater than the CaO adjusted glass. This indicates that calcium oxide was slightly more effective in lowering cs loss while reducing the T100P of the melt (see Table 12).

The increased CS retention in the ORNL ISV glass compared to the Hanford ISV glass could have been due to the operating temperatures of the two processing tests. The operating temperatures for the Hanford ISV test could have been such that the viscosity of the melt was much greater than the melt viscosity for the ORNL ISV processing test. The melt temperatures for these two processing tests are not available to confirm this. The composition of the test melt could also have contributed to the difference in Cs retention, but could not have accounted for all of the difference. 


\subsection{PILOT-SCALE TEST RESULTS AND ANALYSIS}

\subsection{GENERAL OBSERVATIONS}

Sampling strategies were used to compile a material balance for $C s$ and Sr retention. Samples were taken from HEPA filter media, each of the two liquid scrubbers, the off-gas 1 ine and off-gas hood, and the soil below the vitrified mass. Core samples were also taken from the vitrified mass.

Sampling of the off-gas scrub solution provided a quantitative analys is of the amount of $\mathrm{Cs}$ and $\mathrm{Sr}$ released during processing. During the processing period, 58 iiquid samples were taken from the liquid scrub system. Duplicate samples were provided to ORNL for independent evaluations.

The data from samples were corrected for off-gas line and hood smear sizes, tank volumes, and solution transfer volumes for conversion to grams released from the soil to the off-gas system during processing. The converted gram quantities collected in the off-gas system were divided into the amounts of Cs and Sr placed in the soil prior to testing. This method provided a soi1/mass-to-off-gas DF of $1 . D 18 E+3$ for CS and $1.394 \mathrm{E}+6$ for Sr.

The data in Table 13 indicate that the Sr converts to a larger wt\% quantity than that placed in the test site prior to vitrification. The same phenomenon was noted in the engineering-scale test and was thought to occur because the sample was taken in a melt zone created by a higher concentration of $\mathrm{Sr}$ than that distributed throughout the remaining vitrified mass. Previous convection data from testing shows distribution of radionuclides to be within a factor of 3 from the normal distribution (Timmerman and Oma 1984). For the pilot-5cale test a sufficient number of samples were analyzed, and the data evaluated, to show an even distribution of Sr throughout the vitrified mass. All samples evaluated gave equal wto quantities of $\mathrm{Sr}$, which would rule out zones of higher concentration for this element. No explanation for the high $\mathrm{Sr}$ value could be determined during evaluation of the pilot-scale vitrified mass.

The concentration of $\mathrm{CS}_{S}$ and $\mathrm{Sr}$ placed in the soil prior to vitrification testing was several orders of magnitude greater than that found in ORNL Trench 7, where only radioisotopes of these elements were disposed. This 
TABLE 13. $\begin{aligned} & \text { Oxide (Cpmpositions for ORNL ISV Pilot- and Engineering-Scale } \\ & \text { Tests }\end{aligned}$

\begin{tabular}{|c|c|c|c|c|c|c|}
\hline \multirow[b]{2}{*}{ Oxides } & \multicolumn{3}{|c|}{ Pilot-Scale Test } & \multicolumn{3}{|c|}{ Engineering-Scale Test } \\
\hline & Soil & Limestone & $\begin{array}{l}\text { Average } \\
\text { Prod. }\end{array}$ & Soil & Limestone & Product \\
\hline $\mathrm{Al}_{2} \mathrm{O}_{3}$ & 18.3 & 0.97 & 13.1 & 18.8 & 1.55 & 14.7 \\
\hline $\mathrm{BaO}$ & 0.063 & & 0.077 & 0.05 & 0.01 & 0.10 \\
\hline $\mathrm{CaO}$ & 3.09 & 87.3 & 18.3 & 1.57 & 49.7 & 15.0 \\
\hline $\mathrm{Cs}_{2} \mathrm{O}$ & & & 0.35 & & & 1.35 \\
\hline $\mathrm{Fe}_{2} \mathrm{O}_{3}$ & 6.32 & 1.37 & 4.42 & 6.48 & 0.58 & 4.14 \\
\hline $\mathrm{K}_{2} \mathrm{O}$ & 2.7 & & 2.56 & & & 2.28 \\
\hline Mgo & 1.83 & 6.8 & 2.13 & 3.01 & 37.0 & 10.9 \\
\hline $\mathrm{MnO}_{2}$ & 0.12 & 0.39 & 0.14 & 0.21 & 0.00 & 0.14 \\
\hline $\mathrm{Na}_{2} \mathrm{O}$ & 0.77 & 0.65 & 1.52 & 0.61 & 0.07 & 0.93 \\
\hline $\mathrm{SiO}_{2}$ & 63.1 & 2.95 & 51.9 & 68.2 & 10.8 & 45.4 \\
\hline Sro & 0.13 & 0.05 & 1.37 & 0.01 & 0.02 & 4.17 \\
\hline $\mathrm{TiO}_{2}$ & 0.83 & & 0.60 & 0.88 & 0.04 & 0.64 \\
\hline $\mathrm{ZrO}_{2}$ & 0.035 & & 0.038 & 0.06 & 0.06 & 0.035 \\
\hline Total & 97.29 & 100.48 & 96.41 & 99.88 & 99.76 & 99.79 \\
\hline
\end{tabular}

(a) Values in oxide wt?

increased concentration was used to provide detectable levels of $\mathrm{CS}_{\mathrm{S}}$ and $\mathrm{Sr}$ in the off-gas sampling system and detectable quantities for the MCC tests of the vitrified mass. The similarity of leach characteristics for pilot-and engineering-scale test specimens (with their order-of-magnitude differences in (s levels) indicate little effect due to mass loading on the waste from leach behavior.

Durability tests were performed on the pilot-scale vitrified mass. The tests were performed to determine product durability for the $80 / 20$ soil and limestone mixture. The tests also verified the findings of the laboratoryand engineering-scale testing against ORNL's soil and limestone for future scale-up of the ISV process, and application of the process to ORNL trenches and seepage pits. Samples taken directly from the pilot-scale vitrified mass 
were subjected to $M C C-1, M C C-3$, and a modified $M C C-3$ tests. All leach tests were performed at $90^{\circ} \mathrm{C}$ in $\mathrm{DIW}$ (see Section 5.0 ).

\subsection{COMPARISON OF ENGINEERING- AND PILOT-SCALE TEST}

The oxide compositions of the soils, limestones, and waste forms from the pilot- and engineering-scale ORNL ISV tests are presented in Table 13. The soil used in the previously conducted engineering-scale test was very similar to the soil used in the pilot-scale test. However, the crushed 1 imestone used in the engineering-scale test contained approximately 37 wt\% oxides MgO, compared to $6.8 \mathrm{wt} \%$ in the limestone used in the pilot-scale test. In the engineering-scale test, the soil-to-limestone ratio was $68 / 32$ wts. Analysis of the compositions from the pilot-scale test indicated the soil-to-limestone ratio was $80 / 20 \mathrm{wt} \%$. These factors resulted in the compositional difference between the waste form product from the engineeringscale and pilot-scale tests.

Because of the differences in composition, the phase behavior of the two waste forms cannot be directly compared. However, the durability of the two waste forms can be compared because nomalized concentrations and releases were used in the leach testing. Figure 34 compares the results from the MCC-1 testing of the engineering-scale product with the pilot-scale product. The releases are essentially equivalent for both tests, with the exception of potassium in the engineering-scale comparison. The engineering-scale and pilot-scale durability is also compared with PNL 76-68. Figure 33 presented the normalized $S i$ concentrations versus $\log (t \cdot S A / V)$ for the pilot- and engineering-scale products. The forward rates of reaction for the two waste forms are very close, with the engineering-scale product being slightly higher. The differing compositions between the two tests are the major reasons for these small differences.

With leach testing for the laboratory-, engineering-, and pilot-scale tests performed at $90^{\circ} \mathrm{C}$, the ISV process with the different wty soil-tolimestone ratio presents a very durable product, comparable to a specially developed high-Jevel waste form (i.e., PNL 76-68). It is anticipated that if 


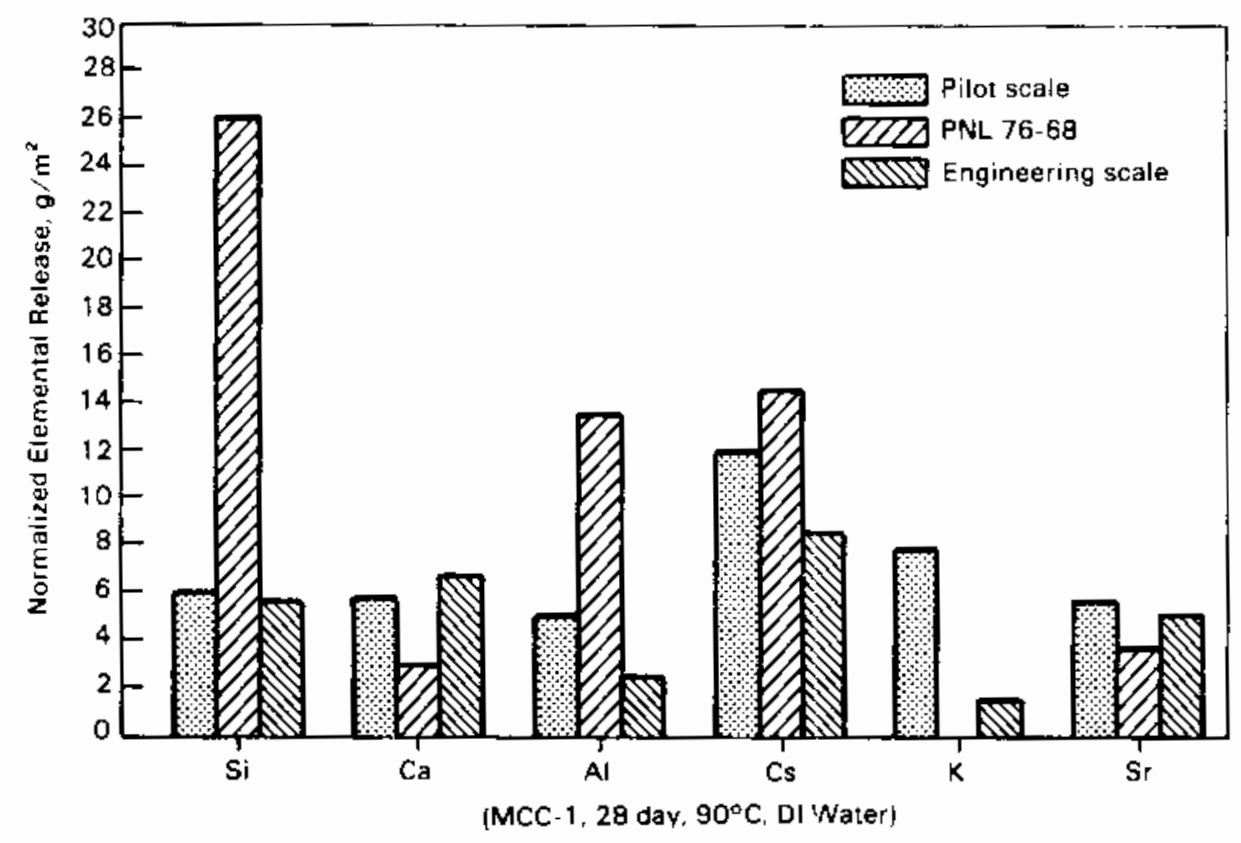

FIGURE 34. Comparison of MCC-1 Tests from Engineering-Scale Product to the Pilot-Scale Product

the vitrified mass leach tests are performed at the lower temperature of $20^{\circ} \mathrm{C}$, to simulate ambient temperature leaching conditions, the leach rates would be one to two orders of magnitude lower.

Higher concentrations of $\mathrm{Na}_{2} \mathrm{O}$ were detected in the samples of the vitrified mass (see Table 4) than that analyzed in the ORNL soil and limestone. One-hundred pounds of soda ash were added to the melt zone starter material to reduce the melt temperature of the ORNL soil, and to accelerate the establishment of the melt path between the electrodes. The $100 \mathrm{lb}$ addition would account for $0.1 \mathrm{wt} \% \mathrm{Na}_{2} \mathrm{O}$. No conclusion could be determined for the higher concentrations.

The ORNL ISV pilot-scale test exceeded the computer model prediction for run time, ISV mass, and energy consumption, and was less than the predicted and average power. The ORNL ISV test required additional operating hours to vitrify the ORNL 3/8-scale test site to the required depth for complete vitrification of the CS and $\mathrm{Sr}$ chemicals placed in the test site. The additional required hours resulted from the longitudinal or lengthwise vitrification into the crushed limestone region of the trench. This lateral vitrification was previously observed in the engineering-scale test. The 
pilot-scale off-gas hood for the ORNL test was designed to allow for longitudinal growth. However, the computer model is not programed to account for longitudinal vitrification and only predicts vitrification of a square, teardrop shape vitrified formation.

Based on the test conclusions resulting from the laboratory-, engineering-, and pilot-scale tests of ORNL soil and limestone at differing soil-to-limestone ratios, the ISV process can vitrify ORNL seepage trenches and pits to produce a very durable product. 



\subsection{REFERENCES}

Brouns, R. A., J. L. Buelt, and W. F. Bonner. 1983. "In Situ Vitrification of Soil." U.S. Patent 4,376,498, March 1983.

Buelt, J. L., and J. G. Carter. 1986. Description and Capabilities of the Large-Scale In Situ Vitrification Process. PNL-5738, Pacific Northwest Laboratory, Richland, Washington.

Buelt, J. L., and S. T. Freim. 1986. Demonstration of In Situ Vitrification for Volume Reduction of Zirconia/Lime Sludges. Pacific Northwest Laboratory, Richland, Washington.

Buelt, J. L., C. C. Chapman, S. M. Barnes, and R. D. Dierks. 1979. "A Review of Continuous Ceramic-Lined Melter and Associated Experience at PNL." In Ceramics and Nuclear Waste Management. Pp. 107-113. CONF-790420. Technical Information Center, Springfield, Virginia.

Buelt, J. L., C. L. Timmerman, K. H. Oma, V. F. FitzPatrick, and J. G. Carter. 1987. In Situ Vitrification of Transuranic Wastes: Systems Evaluation and Applications Assessment. PNL-4800 Supplement 1, Pacific Northwest Laboratory, Richland, Washington.

Bunne11, L. R., G. D. Maupin, and K. H. Oma. 1987. "High-Temperature Glasses for Nuclear Waste Isolation." In Nuclear Waste Management II. Advances in Ceramics. Vol. 20, eds. D. E. Clark, W. B. White, and A. J. Machiels, Pp. 167-173, American Ceramic Society, Columbus, Ohio.

Carter, J. G., S. O. Bates, and G. D. Maupin. 1987. In Situ Vitrification of Oak Ridge National Laboratory Soil and Limestone. PNL-6174, Pacific Northwest Laboratory, Richland, Washington.

Levin, E. M., C. R. Robins, and H. F. McMurdie. 1964, Phase Diagram for Ceramists, Volume 1, pp. 219. American Ceramic Society, Inc., Columbus, ohio.

Materials Characterization Center, Rev. 7, 1986. "MCC-1P Static Leach Test Method." In Nuclear Waste Materials Handbook. Test Methods. DOE/TIC11400. Technical Information Center, Springfield, Virginia.

Mende1, J. E. 1984. Test Methods for Nuclear Waste Materials Handbook. PNL-3990, Pacific Northwest Laboratory, Richland, Washington.

01 sen, C. R., P. D. Lowry, S. Y. Lee, I. L. Larsen, and N. H. Cutshall. 1983. Chemical, Geological, and Hydrological Factors Governing Radionuclide Migration from a Formally Used Seepage Trench: A Field Study, ORNL/TM-8839. Oak Ridge National Laboratory, Oak Ridge, Tennessee. 
Oma, K. H., and C. L. Timmerman, 1984. "Off-Gas Treatment and Characterization for a Radioactive In Situ Vitrification Test." PNL-SA-12000. Paper presented at the 18th DOE Nuclear Airborne Waste Management and Air Cleaning Conference, Baitimore, Maryland.

0sborn, E. F., and A. Muan. 1960. Revised and Redrawn, "Phase Equilibrium Diagrams of Oxide Systems," Plate 1, published by the American Ceramic Society and the Edward Orton, Jr., Ceramic Foundation.

Spalding, B. P. 1987. Environmental Data Package for the ORNL Seepage Pits and Trenches Waste Area Grouping. ORNL/RAP-10, Oak Ridge National Laboratory, Oak Ridge, Tennessee.

Timmerman, C. L., and K. H. Oma, 1984. An In Situ Vitrification Pilot-Scale Radioactive Test. PNL-5240, Pacific Northwest Laboratory, RichTand, Washington.

Timnerman, C. L., R. A. Brouns, J. L. Buelt, and K. H. Oma. 1983. "In Situ Vitrification: Pilot-Scale Development." In Nuclear and Chemical Waste Management, Vol. 4, No. 3, pp. 267-276. Pergamon Press 1nc., Elms ford, New York.

U.S. Environmental Protection Agency. 1986. "Method 1310: Extraction Procedure (EP) Toxicity Test Method and Structural Integrity Test." In Test Methods for Evaluating Solid Waste, SW-846, Vol. 1, Section C, Part 2 (Chapter 8). U.S. Environmental Protection Agency, Washington, D.C. 
APPENDIX A

CALCULATIONS 


\section{Liquid Transfer Conc. Sr}

(Sample Conc) $(\mathrm{Mg} / \mathrm{l})$ (Volume Transferred 1$)=\mathrm{mg} \div 1000=\mathrm{g}$

\section{Date and Time}

Sample No.

$$
\begin{aligned}
& \underset{1-21}{7 / 15 / 87} 0915(0.35)(51) \frac{17.85}{1000}=0.02 \\
& \underset{1-23}{7 / 15 / 87} \odot 1400(0.27)(31) \frac{8.37}{1000}=0.01 \\
& \underset{1-23}{7 / 15 / 87} \odot 1500(0.27)(39) \frac{10.53}{1000}=0.01 \\
& \underset{2-28}{7 / 15 / 87} \odot 2120(0.35)(48) \frac{16.80}{1000}=0.02 \\
& \underset{2-30}{7 / 16 / 87} 0149(0.31)(30) \frac{9.30}{1000}=0.01 \\
& \underset{2-32}{7 / 16 / 87} \odot 0625(0.27)(27) \frac{7.29}{1000}=0.01 \\
& 7 / 16 / 87 @ 1100(0.21)(23) \frac{4.83}{1000}=0.005 \\
& \text { 2-35 } \\
& \underset{2-38}{7 / 16 / 87} @ 1830(0.17)(32) \frac{5.44}{1000}=0.005 \\
& \underset{2-41}{7 / 16 / 87} \odot 2341(0.13) \text { (33) } \frac{4.29}{1000}=0.004 \\
& \underset{2-44}{7 / 17 / 87} \odot 0540(0.12)(19) \frac{2.28}{1000}=0.002 \\
& \underset{2-45}{7 / 17 / 87} 0740(0.13)(18) \frac{2.34}{1000}=0.002 \\
& \underset{2-45}{7 / 17 / 87} 0830(0.13) \text { (9) } \frac{1.17}{1000}=0.001
\end{aligned}
$$




\section{Liquid Transfer Conc. Sr}

(Sample Conc) $(\mathrm{Mg} / \mathrm{l})$ (Volume Transferred 1$)=\mathrm{mg} \div 1000=\mathrm{g}$ Date and Time

Sample No. $\underset{2-47}{7 / 17 / 87} @ 1244(0.09)(15) \frac{1.350}{1000}=0.001$

$7 / 17 / 87 @ 1900(0.08)(28) \frac{2.24}{1000}=0.002$ $2-51$ $\underset{2-53}{7 / 17 / 87} \odot 2300(0.07)(30) \frac{2.10}{1000}=0.002$

$\frac{7 / 18 / 87}{2-54} 00240(0.06)(35) \frac{2.10}{1000}=0.002$

$7 / 18 / 87 \bigcirc 0710(0.05)(48) \frac{2.40}{1000}=0.002$ $2-57$ $\begin{aligned} & 7 / 18 / 87 \\ & 2-58\end{aligned} 1022(0.05)(39) \frac{1.95}{1000}=0.002$

$\underset{2-66}{7 / 18 / 87} \odot 0050(0.09)(283) \frac{25.47}{1000}=0.025$

$\begin{aligned} & 7 / 18 / 87 \\ & 2-68\end{aligned} 0215(0.09)(347) \frac{31.23}{1000}=\underline{0.031}$

Total $0.166 \mathrm{~g}$ 
Liquid Transfer Conc. Cs

(Sample Conc) $(\mathrm{Mg} / \mathrm{l})$ (Volume Transferred 1$)=m g \div 1000=g$

Date and Time

Sample No.

$7 / 15 / 87 @ 0915(0.27)(51) \frac{13.77}{1000}=0.014$ $1-21$

$\underset{1-23}{7 / 15 / 87} @ 1400(0.45)$ (31) $\frac{13.95}{1000}=0.014$

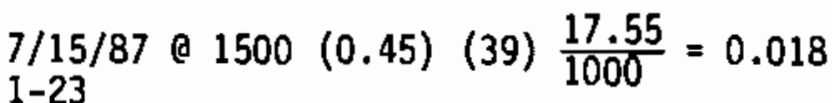

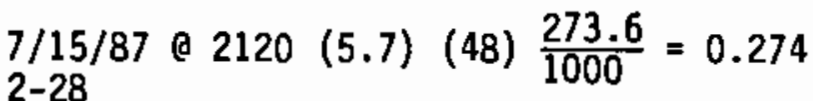

$\underset{2-30}{7 / 16 / 87} 00149(7.9)(30) \frac{237}{1000}=0.237$

$\underset{2-32}{7 / 16 / 87}+0625(8.0)$ (27) $\frac{216}{1000}=0.216$

$7 / 16 / 87$
$2-35$ @ $1100(9.0)(23) \frac{207}{1000}=0.207$

$\begin{aligned} & 7 / 16 / 87 \\ & 2-38\end{aligned} 1830(20.0)(32) \frac{640}{1000}=0.640$

$7 / 16 / 87$
$2-41$ $2341(32.0)$ (33) $\frac{1056}{1000}=1.056$

$\underset{2-44}{7 / 17 / 87} 00540(61.0)$ (19) $\frac{1159}{1000}=1.159$

$\underset{2-45}{7 / 17 / 87} 0740(56.5)$ (18) $\frac{1017}{1000}=1.017$ 


\section{Liquid Iransfer Conc. Cs}

(Sample Conc) $(M g / 1)$ (Volume Transferred 1$)=m g \div 1000=g$

Date and Time

Sample No.

$7 / 17 / 87 @ 0830(56.5)$ (9) $\frac{508.5}{1000}=0.509$

$2-45$

$\underset{2-47}{7 / 17 / 87}$ @ $1244(58.1)$ (15) $\frac{871.5}{1000}=0.872$

$\begin{aligned} & 7 / 17 / 87 \\ & 2-51\end{aligned} 1900(64.6)(28) \frac{1808}{1000}=1.809$

$\frac{7 / 17 / 87}{2-53}+2300(64.3)(30) \frac{1929}{1000}=1.929$ $\underset{2-54}{7 / 18 / 87} \bigcirc 0240(75.7)(35) \frac{2649.5}{1000}=2.650$

$\begin{aligned} & 7 / 18 / 87 \\ & 2-57\end{aligned} 0710(105.4)(48) \frac{5059.2}{1000}=5.059$

$\begin{aligned} & 7 / 18 / 87 \\ & 2-58\end{aligned} 1022(96.1)(39) \frac{3747.9}{1000}=3.748$

$\underset{2-66}{7 / 18 / 87} \odot 0050(127.0)(283) \frac{35.941}{1000}=35.941$

$\begin{aligned} & 7 / 18 / 87 \\ & 2-68\end{aligned} 0215(17.7)(347) \frac{6141.9}{1000}=\underline{6.142}$

Total $\quad 63.51 \mathrm{~g}$ 


\section{Calculation for Limestone to Soil Ratio}

( Amount in Core Sample--Amount in Soil $)(100)=*$

$\begin{array}{lcccc} & \begin{array}{c}\text { Average } \\ \text { Amount in } \\ \text { Core Sample }\end{array} & \begin{array}{c}\text { Amount in } \\ \text { Soil }\end{array} & \begin{array}{c}\text { Amount in } \\ \text { Limestone }\end{array} \\ \mathrm{SiO}_{2} & 51.93 & 58.4 & 2.95 \\ \mathrm{Mg0} & 2.12 & 1.69 & 6.8 \\ \mathrm{Fe}_{203} & 4.42 & 5.86 & 1.3 \\ \mathrm{CaO} & 18.3 & 2.86 & 87.3 \\ \mathrm{Al}_{203} & 13.08 & 16.9 & 0.97\end{array}$

$\mathrm{SiO}_{2} \frac{51.93-58.4}{2.95-58.4}=0.117(100)=11.67 \%$

Mg0 $\frac{2.12-1.69}{6.8-1.69}=0.084(100)=8.42 \%$

$\mathrm{Fe}_{2} \mathrm{O}_{3} \frac{4.42-5.86}{1.3-5.86}=0.316(100)=31.6 \%$

$\mathrm{CaO} \frac{18.3-2.86}{87.3-2.86}=0.183(100)=18.3 \%$

$\mathrm{Al}_{203} \frac{13.08-16.9}{0.97-16.9}=0.240(100)=\underline{23.98 \%}$

Average $=20 \%$ 
$\mathrm{SrCO}_{3}$ and $\mathrm{Cs}_{2} \mathrm{CO}_{3}$ Corrected to $\mathrm{Cs}$ and $\mathrm{Sr}$ Placed in Test Trench

$\underline{\mathrm{SrCO}_{3} \text { Correction to } \mathrm{Sr}}$

$(408,600 \mathrm{~g} \mathrm{SrCO} 3)(97.7 \%$ purity $=399,202 \mathrm{~g} \mathrm{SrCO}$

$399,202 \mathrm{~g} \mathrm{SrCO} 3\left(\frac{87.62}{87.62+12+3(16)}\right)=$

$(399,202 \mathrm{~g} \mathrm{SrC0})\left(\frac{87.62}{147.63}\right)=236,931 \mathrm{~g} \mathrm{Sr}$ placed in test trench

$\mathrm{Cs}_{2} \mathrm{CO}_{3}$ Correction to $\mathrm{Cs}$

$\left(89,892 \mathrm{~g} \mathrm{Cs}_{2} \mathrm{CO}_{3}\right.$ ( (99.9\% parity) $=89,802 \mathrm{~g} \mathrm{Cs} \mathrm{CO}_{3}$

$89,802 \mathrm{~g} \mathrm{Cs}_{2} \mathrm{CO}_{3}\left(\frac{2(133)}{2(133)+12+3(16)}\right)=$

$\left(89,802 \mathrm{~g} \mathrm{Cs} 2 \mathrm{CO}_{3}\right)\left(\frac{266}{326}\right)=73,274 \mathrm{~g}$ Cs placed in test trench 
Conc Sr Inside of Hood Surface

Conc Sr Inside of Off-Gas Line

Hood Measurement:

36 in. $x 216$ in. $\times 2=15,552$ in. 2 on 2 side panels

36 in. $x 120$ in. $\times 2=8,640$ in. 2 an 2 end panels

120 in. $x 216$ in. $\quad=25,920$ in2 on roof panel

Total 50,112 in.2 of hood surface

Smear Surface:

10 in. $x 10$ in. $=100$ in.2

50,112 in. $2 \div 100$ in. $2=501.12$

$501.12 \times 13.16 \mu \mathrm{g} / \mathrm{smear}=6594.74$

$6594.74 \mu \mathrm{g} \div 1 \times 10^{6} \mu \mathrm{g} / \mathrm{g}=0.01 \mathrm{~g}$ Sr on inside of off-gas hood

Off-Gas Line Measurement ( 8 in. Sch 10 pipe):

$21.80 \mathrm{ft} 2 / \mathrm{ft} \times 144-314 \mathrm{in.} 2 / \mathrm{ft}$

$314 \mathrm{in.} 2 / \mathrm{ft} \times 32.25 \mathrm{ft}=10126.5 \mathrm{in} .2$

Smeared Surface:

$10 \mathrm{in.} \times 10 \mathrm{in.}=100 \mathrm{in.} 2$

10126.5 in. $2 \div 100$ in. 2 smear $=101.27$

$101.27 \times 12.78 \mu \mathrm{g} / \mathrm{smear}=1294.23 \mu \mathrm{g}$

$1294.23 \mu \mathrm{g} \div 1 \times 10^{6} \mu \mathrm{g}=0.0013 \mathrm{~g} \mathrm{Sr}$ on inside of off-gas line 
Hood Measurements :

36 in. $\times 216$ in. $\times 2=15,552$ in. 2 on 2 side panels

36 in. $x 120$ in. $\times 2=8,640$ in. 2 on 2 end panels

120 in. $\times 216$ in. $=25,920$ in. 2 on roof pane 1

Total 50,112 in.2 of hood surfaces

Smeared Surface:

10 in. $x 10$ in. $=100$ in. 2

50,112 in. $2 \div 100$ in. $2=501.12$

$501.12 \times 390 \mu \mathrm{Cs} / \mathrm{smear}=195,436.8 \mu \mathrm{g} \mathrm{Cs}$

$195,436.8 \mu \mathrm{g} \div 1 \times 10^{6} \mu \mathrm{g} / \mathrm{g}=0.20 \mathrm{~g}$ Cs on inside of off-gas hood

Off-Gas Line Measurement ( 8 in. sch 10 pipe):

$2.180 \mathrm{ft}^{2} / \mathrm{ft} \times 144=314 \mathrm{in.} 2 / \mathrm{ft}$

$314 \mathrm{in.2} / \mathrm{ft} \times 32.25 \mathrm{ft}=10126.5 \mathrm{in.} 2$

Smeared Surface:

$10 \mathrm{in.} \times 10 \mathrm{in.}=100 \mathrm{in.} 2$

$10126.5 \div 100$ in. 2 smear $=101.27$

$101.27 \times 1000 \mu \mathrm{g} / \mathrm{smear}=101,270 \mu \mathrm{g} \mathrm{Cs}$

$101,270 \mu g \div 1 \times 10^{6} \mu g=0.10 \mathrm{~g}$ Cs on inside of off-gas line 


\section{Correction for Grams CS on HEPA Filter}

Calculation:

$\mu \mathrm{g} / \mathrm{cm}^{2} \div 0.155$ in. $2=\mu \mathrm{g} / \mathrm{in.} .2$

$\mu \mathrm{g} /$ in. $2 \div 1 \times 10^{6} \mu \mathrm{g} / \mathrm{g}=\mathrm{g} / \mathrm{in.} .2$

(g/in.2) $(30,960$ in. 2 in filter $)=$ total grams on filter

Primary Filter Sample Conc

Sample No.

$\mathrm{\mu g} / \mathrm{cm}^{2}$

$1-1$

12.5

$1-2$

11.2

$1-3$

11.7

$2-1$

7.7

$2-2$

13.8

2-3

$\underline{12.9}$

Average

11.63

$\frac{11.63}{0.155}=75.0 \mu \mathrm{g} / \mathrm{in} .2$

$\frac{75.0 \mu \mathrm{g} / \mathrm{in} .2}{1 \times 10^{6} \mu \mathrm{g} / \mathrm{g}} 7.50 \times 10^{-5} \mathrm{~g} / \mathrm{in.2}$

$\left(7.50 \times 10^{-5} \mathrm{~g} / \mathrm{in.2}\right)(30,960 \mathrm{in.} 2)=2.32 \mathrm{~g}$ Cs on primary filter

* Final filter had less than the $<0.005 \mu \mathrm{g} / \mathrm{cm}$ detectable limit 


\section{Correction for Grams Sr on HEPA Filter}

Calculation:

$\mu g / \mathrm{cm}^{2} \div 0.155$ in. $2=\mu g /$ in. 2 - blank $\mu / g /$ in. $2 \mathrm{Sr}$ Conc. $=\mu g /$ in. 2

$\mu g /$ in. $2 \div 1 \times 106 \mu g / g=g / i n .2$

(g/in.2) $(30,960$ in.2 in filter $)=$ total grams on filter

\begin{tabular}{|c|c|}
\hline $\begin{array}{l}\text { Primary Filter } \\
\text { Sample No. } \\
\end{array}$ & $\begin{array}{l}\text { Sample } 0 \\
-\mu \mathrm{g} / \mathrm{cm}^{2}\end{array}$ \\
\hline $1-1$ & 0.058 \\
\hline $1-2$ & 0.055 \\
\hline $1-3$ & 0.06 \\
\hline $2-1$ & 0.05 \\
\hline $2-2$ & 0.06 \\
\hline $2-3$ & 0.05 \\
\hline Average & 0.05 \\
\hline
\end{tabular}

$\frac{0.058}{0.155}=0.374 \mu \mathrm{g} / \mathrm{in} .2-0.284=0.090 \mu \mathrm{g} / \mathrm{in} .2$

$\frac{0.090 \mu \mathrm{g} / \mathrm{in} .2}{1 \times 10^{6}} 9.0 \times 1 \mathrm{~g}^{-8} \mathrm{~g} \mathrm{~g} / \mathrm{in.2}$

$1 \times 10^{6} \mu \mathrm{g} / \mathrm{g}$

$\left(9.0 \times 10^{-8}\right)(30,960)=0.003 \mathrm{gr}$ Sr on primary filter

* Final filter had less than detectable limit Sr 


\section{Calculation of Anticipated Trench 7 Radionuclide Conc's}

Basis: 1 Trench contains: $\left.\begin{array}{r}48,000 \mathrm{Ci} \mathrm{Sr} 90 \\ 231,000 \mathrm{Ci} \mathrm{Cs} 137\end{array}\right\}$ as of 1966

$$
\text { (ref: ORNL/RAP-10 p. 14) }
$$

2 Trench size: length $=71 \mathrm{~m}(\mathrm{p}, \mathrm{C}-117)$

$$
\begin{aligned}
\text { width } & =3.3 \mathrm{~m} \\
\text { depth } & =5.2 \mathrm{~m}
\end{aligned}
$$

3 Melt size: vitrify to a depth of $6.5 \mathrm{~m}$ electrode spacing $4.5 \mathrm{~m}$ use 9 settings (overlap $\sim 1 \mathrm{~m}$ or $10 \%$ ) melt width $=8.7 \mathrm{~m}$

4 Mass mass $=576 \times 10^{3} \mathrm{~kg} /$ setting (less overlap) Vitrified (see attached computer prediction) TOTAL MASS $=9 \times 576 \times 10^{-3} \times 0.9=4.66 \times 10^{6} \mathrm{~kg}$

5 DFs: $C s=99.90 \% \quad S r=99.99 \%$

Amount of $S r, C s$ left in year 1990

$$
\begin{aligned}
& A=A_{0} \mathrm{e}^{-\left(0.693 / \mathrm{T}_{1} / 2\right) \mathrm{t}} \quad \mathrm{t}=1990-1966=24 \mathrm{yr} \\
& 90 \mathrm{Sr}=48,000 \mathrm{Ci} \times \mathrm{e}^{-(0.693 / 30) \times 24}=27,600 \mathrm{Ci} \quad \mathrm{T} 1 / 290 \mathrm{Sr}=28.1 \mathrm{yr} \\
& 137 \mathrm{Cs}=231,000 \mathrm{Cj} \times \mathrm{e}^{-(0.693 / 28.1) \times 24}=127,800 \mathrm{Ci} \quad \mathrm{T} 1 / 2137 \mathrm{Cs}=30.0 \mathrm{yr}
\end{aligned}
$$

Amounts of $\mathrm{Sr}, \mathrm{Cs}$ Collected in Scrub Soln

$$
90 \mathrm{Sr}=(1-0.9999)(27,600)=2.76 \mathrm{Ci} \div 9=0.3 \mathrm{ci} / \mathrm{setting}
$$$$
137 \mathrm{Cs}=(1-0.9990)(127,800)=127 \mathrm{Ci} \div 9=14.2 \mathrm{ci} / \mathrm{setting}
$$ 
Conc of $\mathrm{Sr}, \mathrm{Cs}$ in Glass

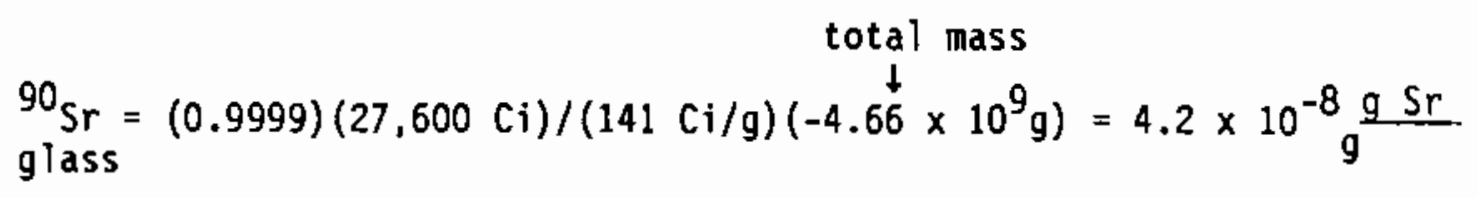

total mass

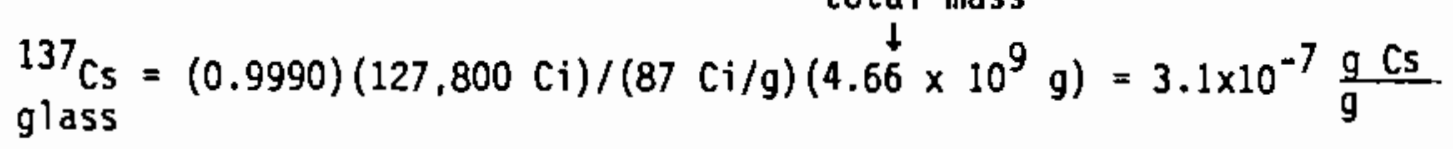

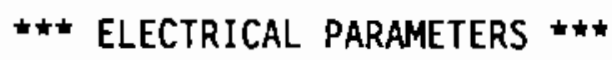

$\begin{array}{lll}\text { Power supply rating } & =3750.00 \mathrm{kH} \\ \text { Maximum supply voltage } & =4160.00 \mathrm{Volts} \\ \text { Maximum melt depth } & =6.50 \mathrm{~m} \\ \text { Calculation depth increment } & =8.67 \mathrm{~cm} \\ \text { Electrode spacing } & =4.50 \mathrm{~m} \\ \text { Electrode diameter } & =5.10 \mathrm{~cm} \\ \text { Number of voltage taps } & =16 \\ \text { Ratio between voltage taps } & =0.840 \\ \text { Frac power loss tap change } & =0.900\end{array}$

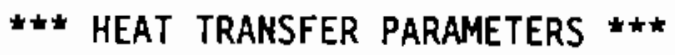

Ht flux through top surface $=32.00 \mathrm{~kW} / \mathrm{m}^{2}$

Ht flux to surrounding soil $=3.20 \mathrm{~kW} / \mathrm{m}^{2}$

Ave. vit. zone temperature $=2000.00^{\circ} \mathrm{C}$

Ave. electrical resistivity $=1.20 \mathrm{ohm}-\mathrm{m}$

Heat capacity molten glass $=0.24 \mathrm{Cal} / \mathrm{g}^{\circ} \mathrm{C}$

Soil moisture (dry bases) $=25.00 \%$

Soil density

Glass density

$=1.60 \mathrm{~g} / \mathrm{cm}^{3}$

$=2.20 \mathrm{~g} / \mathrm{cm}^{3}$ 


\section{Process Scrub Solution Cs Conc.}

Start Scrub Tank Cs Conc.

Calculation $(\mathrm{mg} / 1)($ tank volume 1$)=\frac{\mathrm{mg}}{1000}=$ total grams in tank Sample No.

$2-14(0.40)(139)=\frac{55.6}{1000}=0.06 \mathrm{~g}$

$2-15(0.50)(139)=\frac{69.5}{1000}=0.07 \mathrm{~g}$

Process Scrub Solution CS Conc.

Calculation $(\mathrm{mg} / \mathrm{l})($ tank volume 1$)=\frac{\mathrm{mg}}{1000}=(\mathrm{g})$ - total grams in tank (total gram in tank) - (total grams from previous sample)

(grams transferred to waste drum) $=$ total grams
accumulated

Sample No.

$$
\begin{aligned}
& 1-21(0.27)(339)=\frac{91.5}{1000}=0.092-0.07=0.022+0.014=0.036 \\
& 1-23(0.45)(319)=\frac{143.6}{1000}=0.144-0.092=0.052+0.032=0.084 \\
& 2-25(3.2)(307)=\frac{982.4}{1000}=0.982=0.144=0.838+0=0.839 \\
& 2-28(5.7)(326)=\frac{1858.2}{1000}=1.858-0.982=0.876+0.274=1.150 \\
& 2-30(7.9)(324)=\frac{2559}{1000}=2.560-1.858=0.702+0.237=0.939 \\
& 2-32(8.0)(323)=\frac{2584}{1000}=2.584-2.560=0.024+0=0.024 \\
& 2-33(8.0)(304)=\frac{2432}{1000}=2.432-2.584=(-) 0.152+0.216=0.064
\end{aligned}
$$


Sample No.

$$
\begin{aligned}
& 2-34(8.0)(311)=\frac{2488}{1000}=2.488-2.432=0.056+0=0.056 \\
& 2-35(9.0)(324)=\frac{2916}{1000}=2.916-2.488=0.428+0.207=0.635 \\
& 2-37(20.0)(320)=\frac{6400}{1000}=6.400-2.916=3.484+0=3.484 \\
& 2-38(20.0)(326)=\frac{6520}{1000}=6.520-6.400=0.120+0.640=0.760 \\
& 2-39(22.6)(305)=\frac{6893}{1000}=6.893-6.520=0.373+0=0.373 \\
& 2-40(27.0)(322)=\frac{8694}{1000}=8.694-6.893=1.801+0=1.801 \\
& 2-41(32.0)(322)=\frac{10,304}{1000}=10.304-8.694=1.610+1.056=2.666 \\
& 2-42(47.9)(308)=\frac{14,753}{1000}=14.753-10.304=4.449+0=4.449 \\
& 2-43(56.3)(319)=\frac{17,960}{1000}=17.960-14.753=3.207+0=3.207 \\
& 2-44(61.0)(333)=\frac{20,313}{1000}=20.313-17.960=2.353+1.159=2.353 \\
& 2-45(56.5)(327)=\frac{18,476}{1000}=18.476-20.313=(-) 1.838+1.526=(-) 0.312 \\
& 2-46(59.0)(310)=\frac{18,290}{1000}=18.290-18.476=(-) 0.186+0=(-) 0.186 \\
& 2-47(58.1)(315)=\frac{18,302}{1000}=18.302-18.290=0.012+0.872=0.884 \\
& 2-48(57.2)(300)=\frac{17,160}{1000}=17.160-18.302=(-) 1.142+0.509=(-) 0.633 \\
& 2-49(64.6)(305)=\frac{19,703}{1000}=19.703-17.160=2.543+0=2.543 \\
& 2-50(63.4)(314)=\frac{19,900}{1000}=19.908-19.703=0.205+0=0.205
\end{aligned}
$$


Sample No.

$$
\begin{aligned}
& 2-51(64.6)(331)=\frac{21,383}{1000}=23.383-19.908=1.475+0=1.475 \\
& 2-52(65.1)(310)=\frac{20,181}{1000}=20.181-21.383=(-) 1.202+1.809=0.607 \\
& 2-53(64.3)(333)=\frac{21,412}{1000}=21.412-20.181=1.231+0=1.231 \\
& 2-54(75.7)(323)=\frac{24,451}{1000}=24.451-21.412=3.039+1.929=4.968 \\
& 2-55(79.7)(307)=\frac{24,468}{1000}=24.468-24.451=0.017+2.650=2.667 \\
& 2-56(103)(307)=\frac{31,621}{1000}=31.621-24.468=7.153+0=7.153 \\
& 2-57(105.4)(357)=\frac{37,628}{1000}=37.628-31.621=6.007+0=6.007 \\
& 2-58(96.1)(322)=\frac{30,944}{1000}=30.944-37.628=(-) 6.684+8.807=2.123 \\
& 2-59(96.5)(305)=\frac{29,433}{1000}=29.433-30.944=(-) 1.512+0=(-) 1.512 \\
& 2-60(85.3)(307)=\frac{26,187}{1000}=26.187-29.433=(-) 3.246+0=(-) 3.246 \\
& 2-62(98.1)(326)=\frac{31,981}{1000}=31.981-26.187=5.794+0=5.794 \\
& 2-63(115)(309)=\frac{35,535}{1000}=35.535-31.981=3.554+0=3.554 \\
& 2-64(126)(314)=\frac{39,564}{1000}=39.564-35.535=4.029+0=4.029 \\
& 2-65(130)(313)=\frac{40,690}{1000}=40.690-39.564=1.126+0=1.126 \\
& 2-66(127)(324)=\frac{41,148}{1000}=41.148-40.690=0.458+0=0.458
\end{aligned}
$$


Sample No.

$2-67(127)(332)=\frac{42,164}{1000}=42.164-41.148=1.016+35.941=36.957$

$2-68(17.7)(381)=\frac{6,744}{1000}=6.744-42.164=(-) 35.420+6.142=(-) 29.278$

63.511

69.534

Material check for total gram transfers out (63.511) and total grams accumulated $(69.534)$ 


\section{Process Scrub Solution Sr Conc}

Start Scrub Tank Sr Conc.

Calculation $(\mathrm{mg} / \mathrm{l})($ tank volume 1$)=\frac{\mathrm{mg}}{1000}=$ total grams in tank

Sample No.

$2-14(0.39)(139)=\frac{54.2}{1000}=0.054 \mathrm{~g}$

$2-15(0.41)(139)=\frac{57.0}{1000}=0.057 \mathrm{~g}$

Process Scrub Solution Sr Conc

Calculation $(\mathrm{mg} / \mathrm{l})($ tank volume 1$)=\frac{\mathrm{mg}}{1000}=(\mathrm{g})$ - total grams in tank

(total grams in tank) - (total grams from previous sample)

+ (grams transferred to waste drum) = total grams accumulated

Sample No.

$1-21(0.35)(319)=\frac{111.65}{1000}=0.112-0.057=0.055+0.02=0.075$

$1-23(0.27)(316)=\frac{85.3}{1000}=0.085-0.112=(-) 0.03+0.02=(-) 0.01$

$2-25(0.20)(307)=\frac{61.4}{1000}=0.061-0.085=(-) 0.024+0=(-) 0.024$

$2-28(0.35)(326)=\frac{114.1}{1000}=0.114-0.061=0.053+0.02=0.073$

$2-30(0.31)(324)=\frac{100.4}{1000}=0.100-0.114=(-) 0.014+0.01=(-) 0.004$

$2-32(0.27)(323)=\frac{87.2}{1000}=0.087-0.100=(-) 0.013+0.01=(-) 0.003$

$2-33(0.25)(304)=\frac{76.0}{1000}=0.076-0.087=(-) 0.011+0=(-) 0.011$ 
Sample No.

$$
\begin{aligned}
& 2-35(0.21)(324)=\frac{68.0}{1000}=0.068-0.076=(-) 0.008+0.005=(-) 0.003 \\
& 2-38(0.17)(326)=\frac{55.4}{1000}=0.055-0.068=(-) 0.013+0.005=(-) 0.008 \\
& 2-39(0.16)(305)=\frac{48.8}{1000}=0.049-0.055=(-) 0.006+0=(-) 0.006 \\
& 2-41(0.13)(322)=\frac{41.8}{1000}=0.042-0.049=(-) 0.007+0.004=(-) 0.003 \\
& 2-42(0.12)(308)=\frac{37.0}{1000}=0.037-0.042=(-) 0.005+0=(-) 0.005 \\
& 2-44(0.12)(333)=\frac{39.9}{1000}=0.040-0.037=0.037+0.002=0.005 \\
& 2-45(0.13)(327)=\frac{42.5}{1000}=0.043-0.040=0.003+0.003=0.006 \\
& 2-46(0.10)(310)=\frac{31.0}{1000}=0.031-0.043=(-) 0.012+0=(-) 0.012 \\
& 2-47(0.10)(315)=\frac{28.5}{1000}=0.029-0.031=(-) 0.002+0.001=(-) 0.001 \\
& 2-48(0.08)(300)=\frac{24.0}{1000}=0.024-0.029=(-) 0.005+0=(-) 0.005 \\
& 2-49(0.09)(305)=\frac{27.5}{1000}=0.0275-0.024=(-) 0.003+0=(-) 0.003 \\
& 2-51(0.08)(331)=\frac{26.5}{1000}=0.026-0.027=(-) 0.001+0.002=0.001 \\
& 2-53(0.07)(331)=\frac{23.3}{1000}=0.023-0.026=(-) 0.003+0.002=(-) 0.001 \\
& 2-54(0.06)(323)=\frac{19.4}{1000}=0.019-0.023=(-) 0.004+0.002=(-) 0.002 \\
& 2-55(0.05)(307)=\frac{15.4}{1000}=0.015-0.019=(-) 0.004+0=(-) 0.004 \\
& 2-57(0.05)(357)=\frac{17.9}{1000}=0.018-0.015=0.003+0.002=0.005
\end{aligned}
$$


Sample No.

$$
\begin{aligned}
& 2-58(0.05)(322)=\frac{16.1}{1000}=0.016-0.018=(-) 0.002+0.002=0.000 \\
& 2-59(0.05)(305)=\frac{15.3}{1000}=0.015-0.016=(-) 0.001+0=(-) 0.001 \\
& 2-60(0.06)(307)=\frac{18.4}{1000}=0.018=0.015=0.003+0=0.003 \\
& 2-62(0.06)(326)=\frac{19.6}{1000}=0.020-0.018=0.002+0=0.002 \\
& 2-64(0.09)(314)=\frac{28.3}{1000}=0.028-0.20=0.008+0=0.008 \\
& 2-66(0.09)(324)=\frac{29.2}{1000}=0.029-0.028=0.001+0.025=0.026 \\
& 2-67(0.10)(332)=\frac{33.2}{1000}=0.033-0.029=0.004+0=0.004 \\
& 2-68(0.09)(381)=\frac{34.3}{1000}=0.034-0.033=0.001+0.031=0.032 \\
& 2-0.166 \mathrm{~g} 0.133 \mathrm{~g}
\end{aligned}
$$

Material check for total gram transferred out $(0.166)$ and total gram accumulated (0.133) 


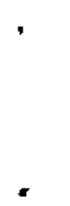

. 


\section{APPENDIX B}

ANALYTICAL DATA FOR PROCESS SCRUB SOLUTIONS 
TABLE B.1. Reference Samples Taken Prior to Run

(all analyses are reported in $\mathrm{mg} / \mathrm{L}$ )

Sample Identification Number

Element

A1

$\frac{2-14}{17} \quad \frac{2-15}{17.04}$

B

120.1

133.70

$\mathrm{Ca}$

34.5

35.70

$\mathrm{Cr}$

3.7

4.1

Cs

0.40

0.50

$\mathrm{Fe}$

29.07

57.2

30.06

K

30.5

64.2

Li

26.2

33.7

Mg

Mn

Mo

2.13

2B. 2

2.66

2.37

$\mathrm{Na}$

389

$\mathrm{Ni}$

0.13

2.91

144.3

$P$

14.8

0.14

Si

2066

18.6

$\mathrm{Sr}$

0.39

2250

Zn

25.4

0.41

Ppt

$1832 \mathrm{mg} / \mathrm{L}$

19.3

$1832 \mathrm{mg} / \mathrm{L}$ 
TABLE B.2. Samples Analyzed for Process Performance (all analyses are reported in $\mathrm{mg} / \mathrm{L}$ )

Sample Identification Number

\begin{tabular}{|c|c|c|c|c|c|c|c|c|}
\hline \multirow[b]{2}{*}{ Element } & \\
\hline & $1-21$ & $1-23$ & $2-25$ & $2-28$ & $2-29$ & $2-30$ & $2-32$ & $2-33$ \\
\hline Al & 43.4 & 34.7 & 31.8 & 27.7 & 24.9 & 20.4 & 15.3 & 13.8 \\
\hline B & 802 & 712 & 552 & 600 & 514 & 433 & 310 & 270 \\
\hline $\mathrm{Ca}$ & 43.2 & 40.7 & 45.8 & 49.9 & 42.0 & 36.9 & 26.4 & 22.6 \\
\hline $\mathrm{cd}$ & & & & 0.36 & 2.01 & 0.34 & 0.23 & 0.21 \\
\hline $\mathrm{Cr}$ & 4.19 & 2.76 & 2.90 & 4.49 & 4.38 & 5.19 & 5.63 & 5.63 \\
\hline Cs & 0.27 & 0.45 & 3.2 & & 5.5 & 8 & 8 & 8 \\
\hline $\mathrm{Cu}$ & 1.33 & 0.84 & 0.69 & 2.04 & 1.81 & 1.79 & 1.81 & 1.70 \\
\hline $\mathrm{Fe}$ & 49.3 & 39.6 & 39.4 & 43.9 & 44.2 & 44.0 & 45.2 & 44.6 \\
\hline $\mathrm{Li}$ & 142.7 & 128 & 130 & 124 & 107 & 88.2 & 63.9 & 55.4 \\
\hline $\mathrm{Mg}$ & 49.3 & 47.6 & 49.4 & 45.8 & 38.9 & 32.1 & 23.1 & 20.4 \\
\hline$M n$ & 4.75 & 4.56 & 5.56 & 5.43 & 4.74 & 4.07 & 3.05 & 2.73 \\
\hline Mo & 3.84 & 4.4 & 4.99 & 4.93 & 4.85 & 4.72 & 4.52 & 3.23 \\
\hline $\mathrm{Na}$ & 4,610 & 4,470 & 4,470 & 3,770 & 3,190 & 2,720 & 1,950 & 1,680 \\
\hline $\mathbf{N i}$ & & & & 4.05 & 4.77 & 4.88 & 4.80 & 4.35 \\
\hline $\mathbf{P}$ & 67.8 & 62.6 & 49.1 & 37.0 & 39.2 & 28.1 & 23.6 & 21.4 \\
\hline $\mathrm{Pb}$ & 25.1 & 20.0 & 20.4 & 18.3 & 14.7 & 12.9 & 9.8 & 9.46 \\
\hline \multicolumn{9}{|l|}{$S$} \\
\hline $\mathrm{Si}$ & 10,270 & 8,260 & 8,280 & 5,940 & 5,230 & 3,940 & 2,940 & 2,600 \\
\hline $\mathrm{Sr}$ & 0.35 & 0.27 & 0.20 & 0.35 & 0.33 & 0.31 & 0.27 & 0.25 \\
\hline $\mathrm{Ti}$ & 2.08 & 1.68 & 0.74 & 0.85 & 0.55 & 0.70 & 0.53 & 0.53 \\
\hline $\mathrm{Zn}$ & 50.0 & 45.8 & 53.6 & 58.2 & 51.6 & 50.0 & 35.9 & 32.4 \\
\hline Ppt & $2.94 \times 10^{4}$ & $2.41 \times 10^{4}$ & $2.17 \times 10^{4}$ & & $1.34 \times 10^{4}$ & $1.06 \times 10^{4}$ & $8.07 \times 10^{3}$ & $6.88 \times 10^{3}$ \\
\hline
\end{tabular}


IABLE B.2. (contd)

Sample Identification Number

\begin{tabular}{|c|c|c|c|c|c|c|c|c|}
\hline \multirow{2}{*}{ Element } & \\
\hline & $2-34$ & $2-35$ & $2-37$ & $2-38$ & 2-39 & $2-40$ & $2-41$ & $2-42$ \\
\hline Al & 11.8 & 10.9 & 9.36 & 8.81 & 8.48 & 12.0 & 6.73 & 6.37 \\
\hline B & 237 & 206 & 175 & 158 & 144 & 138 & 124 & 112 \\
\hline $\mathrm{Ca}$ & 19.4 & 18.0 & 15.0 & 13.7 & 12.9 & 18.5 & 10.6 & 9.82 \\
\hline $\mathrm{cd}$ & 0.19 & 0.19 & 0.19 & 0.14 & 0.16 & 0.14 & 0.13 & 0.14 \\
\hline $\mathrm{Cr}$ & 5.53 & 5.54 & 6.16 & 6.66 & 6.65 & 11.3 & 7.23 & 7.39 \\
\hline $\mathrm{Cs}$ & 8 & 9 & 20 & 20 & 22.6 & 27 & 32 & 47.9 \\
\hline $\mathrm{Cu}$ & 1.61 & 1.64 & 1.46 & 1.40 & 1.18 & 1.39 & 1.09 & 1.07 \\
\hline $\mathrm{Fe}$ & 42.8 & 43.1 & 43.0 & 45.3 & 45.9 & 64.7 & 7.21 & 45.7 \\
\hline $\mathbf{L i}$ & 45.9 & 41.7 & 35.5 & 32.3 & 29.3 & 24.8 & 25.5 & 22.3 \\
\hline $\mathrm{Mg}$ & 16.7 & 15.5 & 12.7 & 11.6 & 11.7 & 17.0 & 8.56 & 7.87 \\
\hline$M n$ & 2.35 & 2.19 & 1.90 & 1.82 & 1.73 & 3.64 & 1.62 & 1.57 \\
\hline Mo & 2.66 & 2.35 & 2.14 & 1.76 & 1.82 & 1.55 & 1.50 & 1.42 \\
\hline $\mathrm{Na}$ & 1,410 & 1,280 & 1,110 & 1,000 & 915 & 857 & 781 & 702 \\
\hline $\mathrm{Ni}$ & 4.16 & 3.47 & 3.55 & 3.69 & 3.33 & 4.26 & 3.69 & 3.90 \\
\hline $\mathbf{P}$ & 19.5 & 19.1 & 16.9 & 15.5 & 13.8 & 20.1 & 11.8 & 11.3 \\
\hline $\mathrm{Pb}$ & 9.35 & 8.29 & 10.3 & 10.1 & 9.78 & 13.5 & 10.5 & 11.5 \\
\hline \multicolumn{9}{|l|}{$S$} \\
\hline $\mathrm{Si}$ & 2,100 & 1,920 & 1,550 & 1,410 & 1,240 & 999 & 1,070 & 958 \\
\hline $\mathrm{Sr}$ & 0.23 & 0.21 & 0.18 & 0.17 & 0.16 & 0.27 & 0.13 & 0.12 \\
\hline$T i$ & 0.47 & 0.47 & 0.44 & 0.42 & 0.44 & 0.56 & 0.34 & 0.33 \\
\hline $\mathrm{Zn}$ & 29.5 & 27.0 & 23.9 & 23.0 & 21.5 & 40.3 & 20.8 & 20.6 \\
\hline Ppt & $5.78 \times 10^{3}$ & $5.08 \times 10^{3}$ & $4.03 \times 10^{3}$ & $3.61 \times 10^{3}$ & $3.29 \times 10^{3}$ & $2.99 \times 10^{3}$ & $2.63 \times 10^{3}$ & $2.32 \times 10^{3}$ \\
\hline
\end{tabular}


TABLE B.2. (contd)

Sample Identification Number

\begin{tabular}{|c|c|c|c|c|c|c|c|c|}
\hline Element & $2-43$ & $2-44$ & $2-45$ & $2-46$ & $2-47$ & $2-48$ & $2-49$ & $2-50$ \\
\hline Al & 5.92 & 6.30 & 5.96 & 4.91 & 4.53 & 4.37 & 4.71 & 4.44 \\
\hline B & 102 & 95.9 & 87.5 & 77.0 & 69.1 & 63.7 & 64.3 & 61.7 \\
\hline $\mathrm{Ca}$ & 9.07 & 9.60 & $9.0 \mathrm{~B}$ & 6.97 & 6.17 & 5.78 & 6.62 & 6.19 \\
\hline Cd & 0.12 & 0.21 & 0.20 & 0.20 & 0.13 & 0.12 & 0.24 & 0.18 \\
\hline $\mathrm{Cr}$ & 8.04 & 9.83 & 11.2 & 11.6 & 12.8 & 14.0 & 17.7 & 19.5 \\
\hline Cs & 56.3 & 61.0 & 56.5 & 59 & 58.1 & 57.2 & 64.6 & 63.4 \\
\hline $\mathrm{Cu}$ & 1.11 & 0.31 & 0.29 & 0.21 & & & & \\
\hline $\mathrm{Fe}$ & 46.8 & 52.4 & 56.3 & 57.3 & 61.1 & 65 & 77.8 & 83.5 \\
\hline $\mathrm{Li}$ & 20.2 & 18.1 & 16.6 & 15.5 & 14.0 & 12.8 & 11.9 & 11.4 \\
\hline Mg & 7.25 & 7.49 & 7.09 & 5.59 & 5.04 & 4.56 & 5.25 & 5.07 \\
\hline$M n$ & 1.52 & 1.65 & 1.72 & 1.65 & 1.70 & 1.77 & 2.15 & 2.27 \\
\hline Mo & 1.34 & 1.23 & 1.13 & 0.84 & 0.68 & 0.64 & 0.66 & 0.68 \\
\hline $\mathrm{Na}$ & 638 & 560 & 504 & 476 & 425 & 395 & 369 & 352 \\
\hline $\mathrm{Ni}$ & 4.08 & 4.77 & 5.09 & 5.13 & 5.54 & 6.03 & 7.62 & 8.43 \\
\hline$P$ & 11.2 & 11.5 & 10.2 & 7.80 & 7.03 & 6.70 & 7.00 & 6.40 \\
\hline $\mathrm{Pb}$ & 11.7 & 10.9 & 11.4 & 9.74 & 4.97 & 14.7 & 11.3 & 11.9 \\
\hline$S$ & & & & & & & & 702 \\
\hline Si & 869 & 794 & 757 & 638 & 609 & 513 & 551 & 530 \\
\hline Sr & 0.13 & 0.12 & 0.13 & 0.10 & 0.09 & 0.08 & 0.09 & 0.09 \\
\hline $\mathrm{Ti}$ & 0.38 & 0.43 & 0.45 & 0.30 & 0.29 & 0.30 & 0.38 & 0.35 \\
\hline $\mathrm{Zn}$ & 19.4 & 17.8 & 16.5 & 14.3 & 12.9 & 12.1 & 13.1 & 12.9 \\
\hline Ppt & $2.07 \times 10^{3}$ & $1.90 \times 10^{3}$ & $1.71 \times 10^{3}$ & $1.44 \times 10^{3}$ & $1.39 \times 10^{3}$ & $1.10 \times 10^{3}$ & $1.22 \times 10^{3}$ & $1.18 \times 10^{3}$ \\
\hline
\end{tabular}


TABLE B.2. (contd)

Sample Identification Number

\begin{tabular}{|c|c|c|c|c|c|c|c|c|}
\hline \multirow[b]{2}{*}{ Element } & \\
\hline & $2-51$ & $2-52$ & $2-53$ & $2-54$ & $2-55$ & $2-56$ & $2-57$ & $2-58$ \\
\hline A1 & 4.43 & 4.34 & 4.02 & 3.53 & 3.09 & 3.88 & 3.18 & 3.06 \\
\hline B & 58.6 & 56.1 & 51.1 & 45.2 & 41.8 & 39.0 & 36.2 & 43.5 \\
\hline $\mathrm{Ca}$ & 6.17 & 5.91 & 5.19 & 4.23 & 3.92 & 3.66 & 3.52 & 3.34 \\
\hline $\mathrm{Cd}$ & 0.17 & 0.39 & 0.16 & 0.17 & 0.12 & 0.13 & 0.12 & 0.12 \\
\hline $\mathrm{Cr}$ & 20.5 & 20.9 & 20.2 & 18.2 & 17.5 & 17.1 & 16.9 & 16.7 \\
\hline Cs & 64.6 & 65.1 & 64.3 & 75.7 & 79.7 & 103 & 105.4 & 96.1 \\
\hline $\mathrm{Cu}$ & 0.17 & 0.34 & 0.40 & 0.67 & 0.58 & 0.52 & 0.39 & 0.27 \\
\hline $\mathrm{Fe}$ & 86.5 & 87.5 & 83.9 & 75.7 & 73.1 & 71.5 & 70.4 & 69.2 \\
\hline Li & 10.8 & 10.4 & 9.54 & 9.06 & 8.39 & 7.88 & 7.25 & 6.67 \\
\hline $\mathrm{Mg}$ & 4.90 & 4.77 & 4.44 & 3.83 & 2.96 & 2.08 & 3.13 & 2.71 \\
\hline$M n$ & 2.16 & 2.39 & 2.27 & 2.04 & 1.97 & 1.92 & 1.86 & 1.78 \\
\hline Mo & 0.72 & 0.78 & 0.78 & 0.74 & 0.77 & 0.77 & 0.81 & 0.84 \\
\hline $\mathrm{Ha}$ & 334 & 318 & 289 & 262 & 240 & 223 & 202 & 183 \\
\hline $\mathrm{Mi}$ & 8.91 & 9.42 & 9.16 & 8.31 & 8.01 & 7.61 & 7.19 & 7.01 \\
\hline $\mathbf{P}$ & 5.83 & 5.32 & 5.12 & 4.27 & 3.98 & 3.94 & 3.77 & 3.52 \\
\hline $\mathrm{Pb}$ & 12.9 & 13.7 & 13.8 & 13.3 & 11.6 & 10.4 & 10.3 & 8.90 \\
\hline \multicolumn{9}{|l|}{$s$} \\
\hline Si & 537 & 519 & 494 & 491 & 461 & 456 & 455 & 424 \\
\hline $\mathrm{Sr}$ & 0.08 & 0.08 & 0.07 & 0.06 & 0.05 & 0.05 & 0.05 & 0.05 \\
\hline $\mathrm{Ti}$ & 0.50 & 0.35 & 0.29 & 0.27 & 0.28 & 0.23 & 0.25 & 0.27 \\
\hline $\mathrm{Zn}$ & 13.0 & 13.1 & 13.3 & 13.8 & 14.2 & 14.4 & 14.4 & 13.9 \\
\hline Ppt & $1.17 \times 10^{3}$ & $1.10 \times 10^{3}$ & $1.03 \times 10^{3}$ & $1.04 \times 10^{3}$ & 701 & 933 & 907 & 805 \\
\hline
\end{tabular}


TABLE B.2. (contd)

Sample Identification Number

\begin{tabular}{|c|c|c|c|c|c|c|c|c|}
\hline Element & $2-59$ & $2-60$ & $2-61$ & $2-62$ & $2-63$ & $2-64$ & $2-65$ & $2-66$ \\
\hline A1 & 3.08 & 3.26 & 2.77 & 2.95 & 3.80 & 4.07 & 4.41 & 4.12 \\
\hline B & 31.4 & 29.9 & 31.0 & 33.1 & 40.7 & 43.4 & 45.6 & 45.7 \\
\hline $\mathrm{Ca}$ & 3.26 & 3.74 & 3.10 & 3.25 & 3.53 & 3.66 & 4.99 & 4.03 \\
\hline$c d$ & 0.11 & 0.11 & 0.13 & 0.12 & 0.15 & 0.14 & 0.13 & 0.14 \\
\hline $\mathrm{Cr}$ & 15.0 & 13.8 & 13.8 & 13.5 & 15.9 & 17.1 & 17.3 & 17.3 \\
\hline $\mathrm{Cs}$ & 96.5 & 85.3 & 87.1 & 98.1 & 115 & 126 & 130 & 127 \\
\hline $\mathrm{Cu}$ & 0.37 & 0.60 & 0.68 & 0.73 & 0.92 & 0.97 & 1.00 & 0.92 \\
\hline $\mathrm{Fe}$ & 62.6 & 57.2 & 47.0 & 56.1 & 65.8 & 70.8 & 72.3 & 72.0 \\
\hline Li & 6.21 & 5.67 & 5.45 & 5.99 & 7.38 & 7.80 & 8.00 & 7.92 \\
\hline $\mathrm{Mg}$ & 2.66 & 2.77 & 2.52 & 2.84 & 3.28 & 3.54 & 3.49 & 3.40 \\
\hline Mn & 1.68 & 1.53 & 1.54 & 1.55 & 1.84 & 1.99 & 2.02 & 2.00 \\
\hline Ho & 1.38 & 2.73 & 5.40 & 11.7 & 27.4 & 43.3 & 57.2 & 63.6 \\
\hline $\mathrm{Na}$ & 167 & 159 & 150 & 165 & 184 & 168 & 204 & 202 \\
\hline $\mathrm{Mi}$ & 8.43 & 8.25 & 8.53 & 8.30 & 9.72 & 10.3 & 10.2 & 10.2 \\
\hline $\mathbf{P}$ & 2.72 & 2.64 & 2.97 & 3.06 & 3.73 & 4.52 & 4.52 & 4.52 \\
\hline $\mathbf{P b}$ & 10.0 & 11.5 & 11.2 & 10.9 & 10.8 & 12.3 & 12.9 & 13.3 \\
\hline \multicolumn{9}{|l|}{5} \\
\hline Si & 416 & 383 & 381 & 436 & 547 & 603 & 602 & 591 \\
\hline Sr & 0.05 & 0.06 & 0.05 & 0.06 & 0.08 & 0.09 & 0.10 & 0.09 \\
\hline $\mathrm{Ti}$ & 0.25 & 0.31 & 0.30 & 0.30 & 0.37 & 0.42 & 0.65 & 0.44 \\
\hline $\mathrm{Zn}$ & 14.8 & 17.2 & 21.1 & 24.0 & 31.3 & 34.8 & 39.1 & 40.8 \\
\hline Ppt & 853 & 762 & 740 & 849 & $1.08 \times 10^{4}$ & $1.19 \times 10^{4}$ & $1.18 \times 10^{4}$ & $1.16 \times 10^{\circ}$ \\
\hline
\end{tabular}


IABLE B.2. (contd)

Sample Identification Number

\begin{tabular}{|c|c|c|}
\hline Element & $2-67$ & $2-68$ \\
\hline Al & 4.35 & 2.74 \\
\hline B & 46.9 & 17.3 \\
\hline $\mathrm{Ca}$ & 4.30 & 14.8 \\
\hline Cd & 0.16 & \\
\hline $\mathrm{Cr}$ & 17.7 & 2.47 \\
\hline Cs & 127 & 17.7 \\
\hline Cu & 0.95 & \\
\hline $\mathrm{Fe}$ & 74.1 & 14.7 \\
\hline Li & 8.22 & 3.90 \\
\hline Mg & 3.45 & 10.1 \\
\hline Mn & 2.06 & 0.37 \\
\hline Mo & 68.6 & 15.3 \\
\hline $\mathrm{Na}$ & 210 & 432 \\
\hline $\mathrm{Mi}$ & 10.3 & 0.92 \\
\hline $\mathbf{P}$ & 4.32 & 1.81 \\
\hline $\mathrm{Pb}$ & 14.2 & 13.2 \\
\hline \multicolumn{3}{|l|}{$S$} \\
\hline $\mathbf{S i}$ & 619 & 464 \\
\hline $\mathrm{Sr}$ & 0.10 & 0.09 \\
\hline $\mathrm{Ji}$ & 0.43 & \\
\hline $\mathrm{Zn}$ & 43.0 & 5.79 \\
\hline Ppt & $1.22 \times 10^{4}$ & $1.26 \times 10^{4}$ \\
\hline
\end{tabular}


APPENDIX C

MISCELLANEOUS FIGURES 
APPENDIX C

\section{MISCELLANEOUS FIGURES}

The following figures present data that are not critical for operations but would be useful for future design considerations.

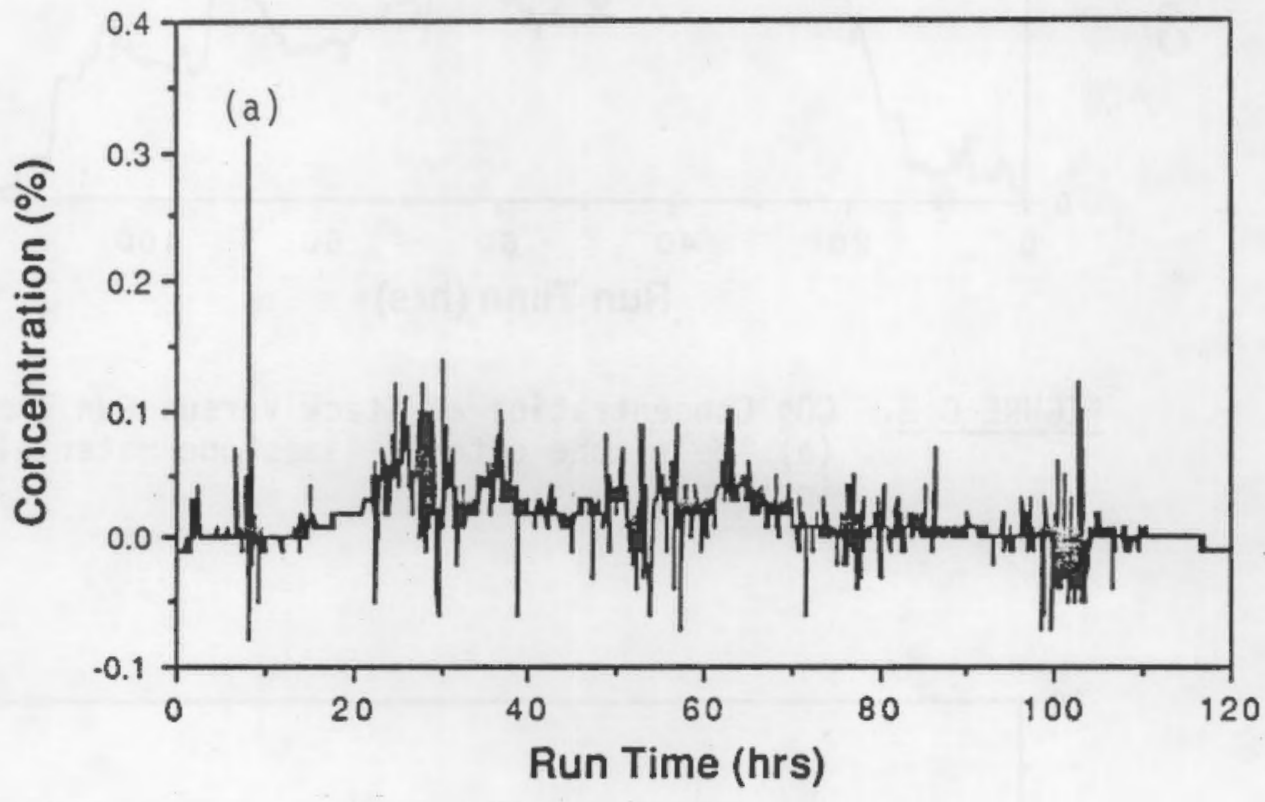

FIGURE C.1. CO Concentration at Stack Versus Run Time. (a) High CO concentration due to the burning of the graphite starter path 


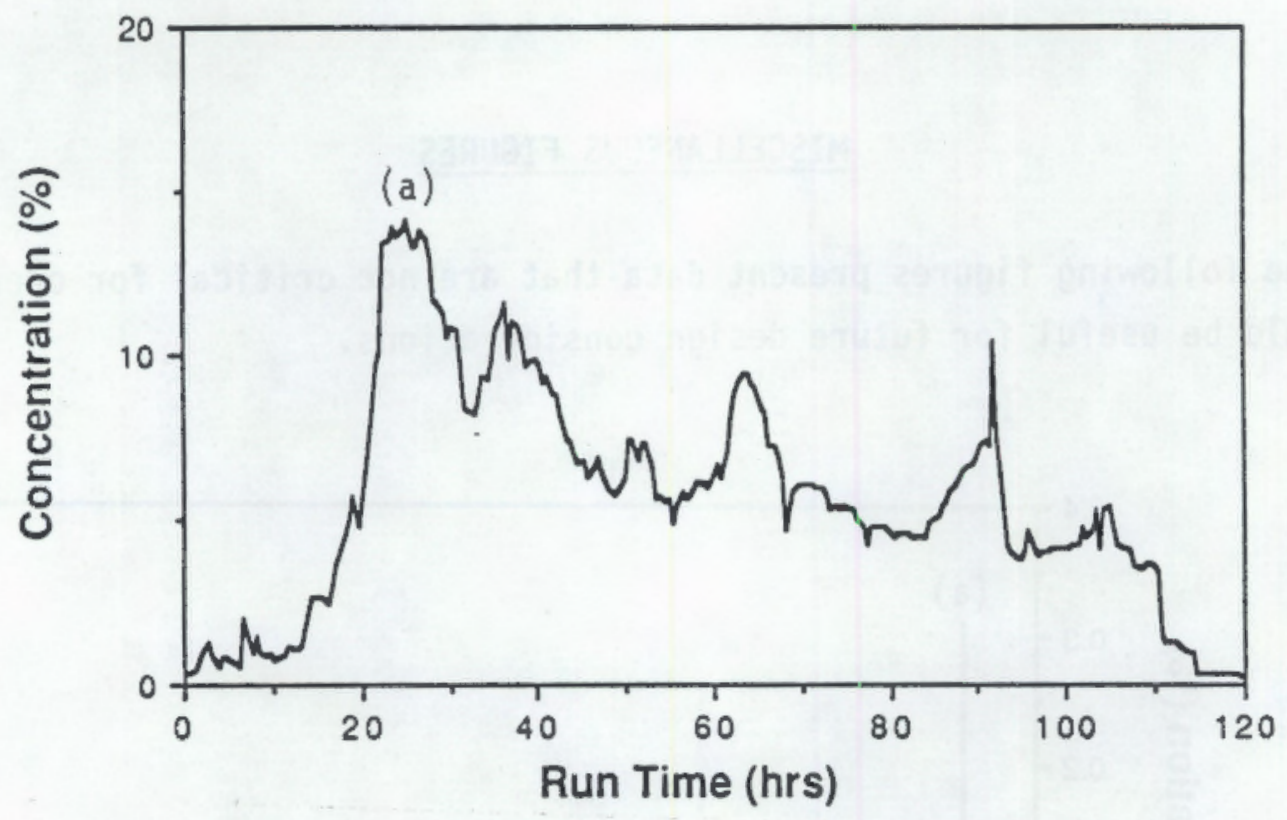

FIGURE C.2. $\mathrm{CO}_{2}$ Concentration at Stack Versus Run Time. (a) Melt zone entered limestone material in trench.

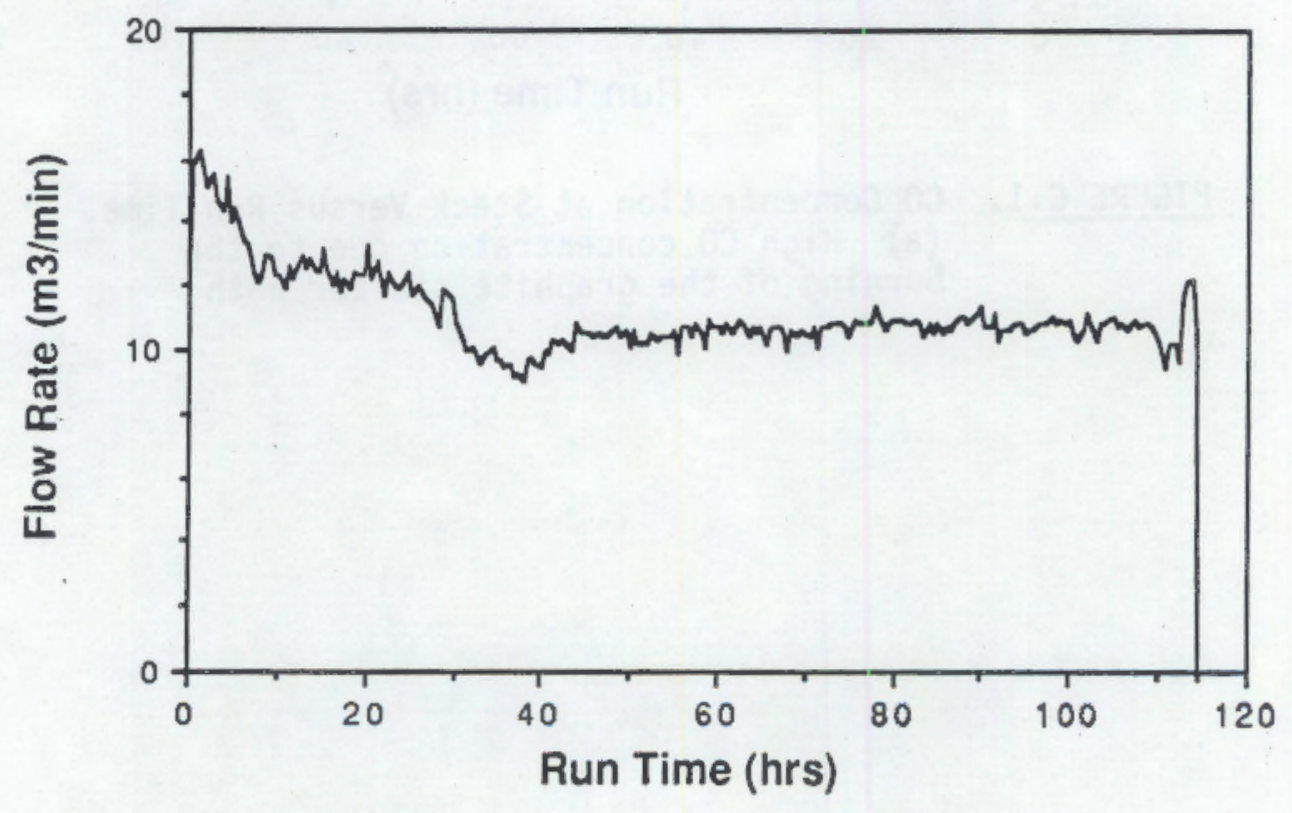

FIGURE C.3. Off-gas Flow at Stack Versus Run Time C.2 


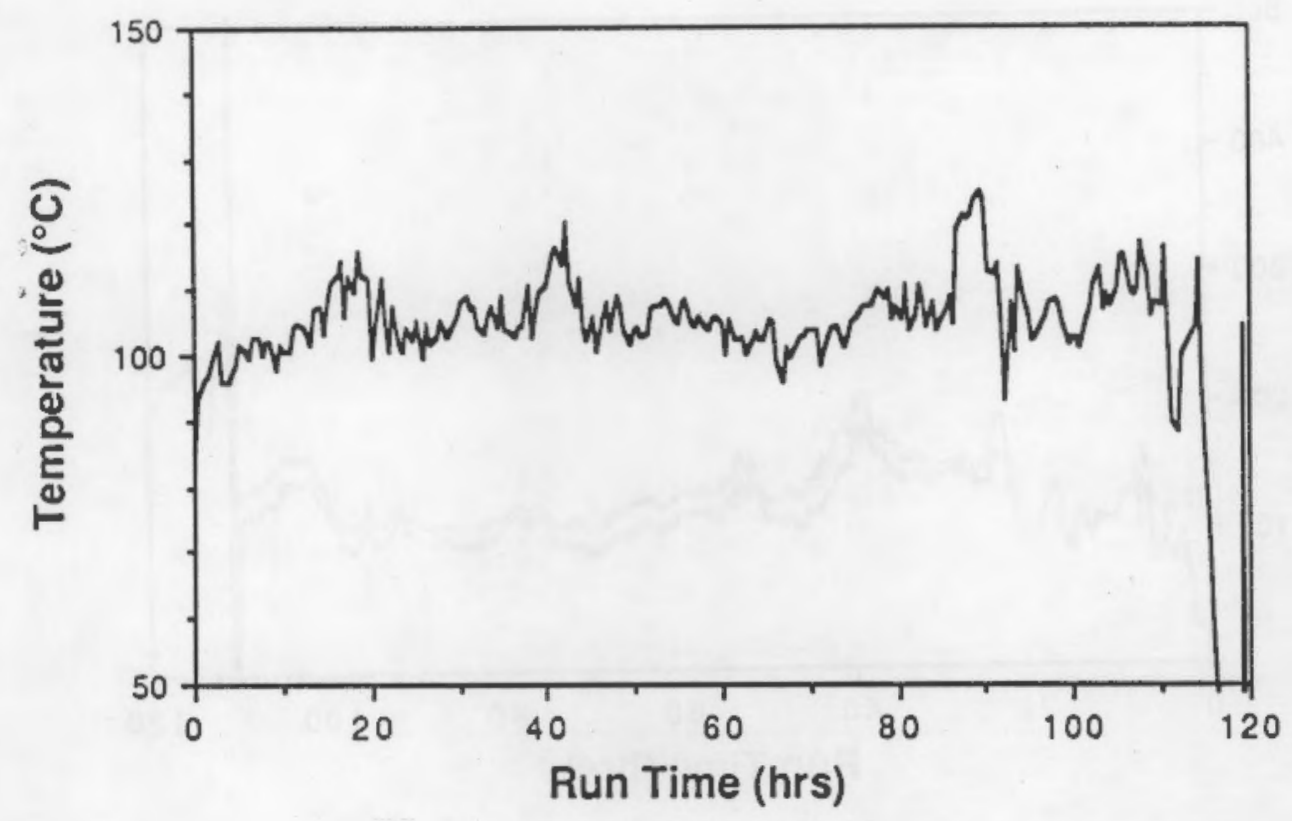

FIGURE C.4. Process Off-gas Stack Temperature Versus Run Time

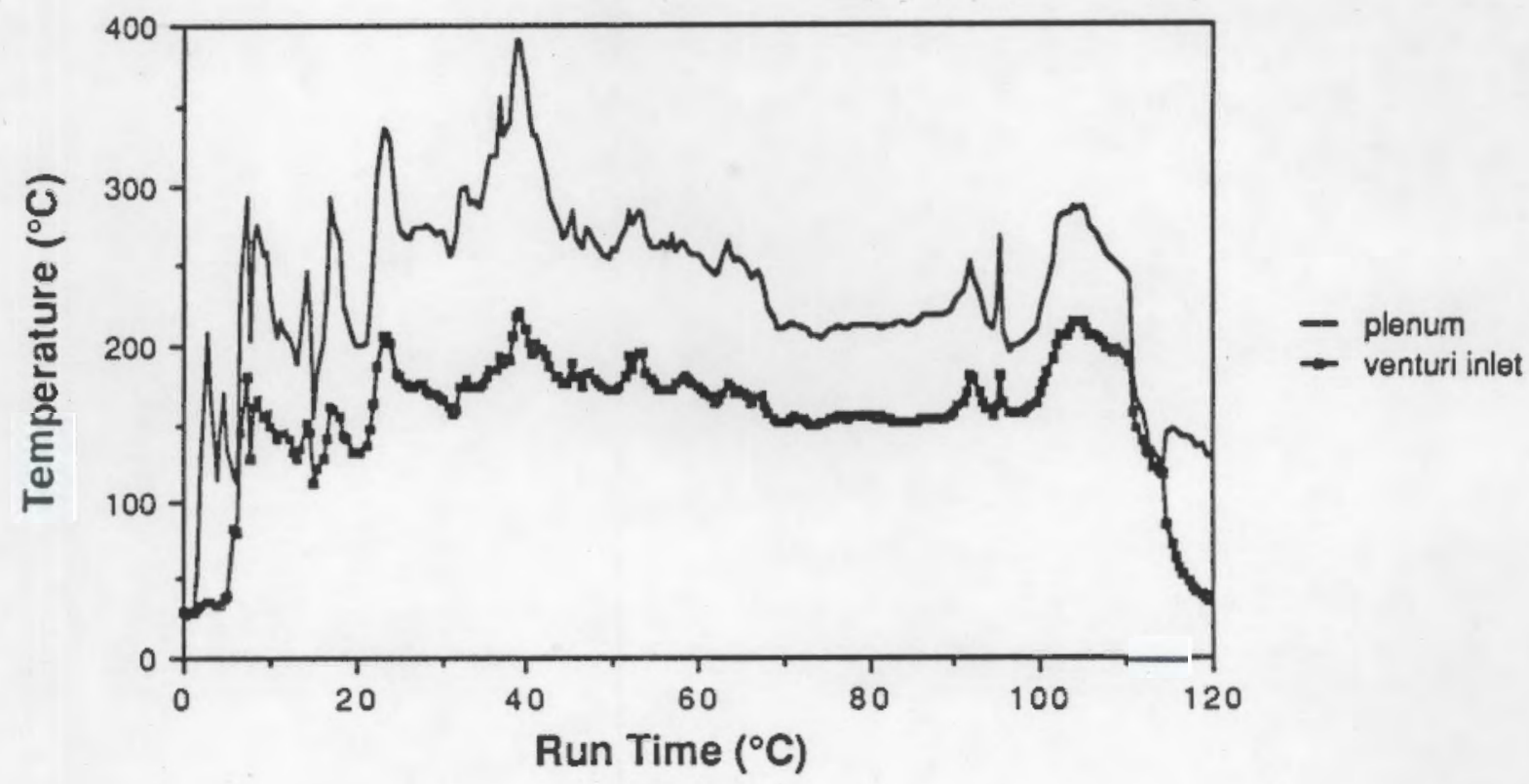

FIGURE C.5. Off-gas Hood Plenum Temperature and Venturi Scrubber Inlet Temperature Versus Run Time 


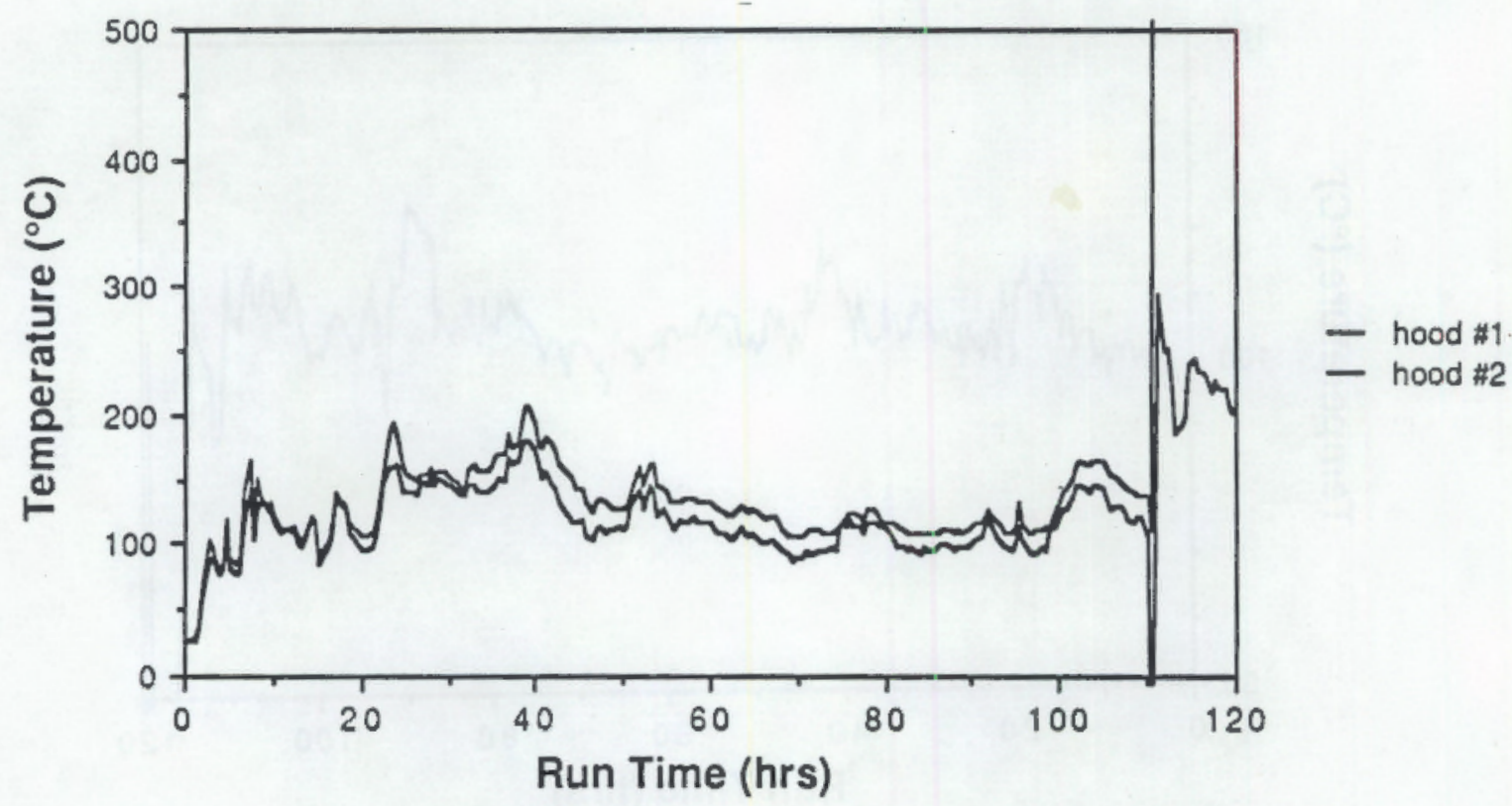

FIGURE C.6. Off-gas Hood Temperature Versus Run Time 


\section{APPENDIX D}

ANALYTICAL DATA FOR VITRIFIED MASS 


\section{MCC-1 TEST RESULTS}

The following are copies of spreadsheet files used to calculate the normalized mass release from $\mathrm{MCC}-1$ leach testing. The ppm values listed are directly from ICP (AA for Cs) analytical results of test leachants. The equation used for the calculations are provide in the test. Oxide wto values are from ICP analysis of the glass or crystalline product.

\begin{tabular}{|c|c|c|c|c|}
\hline $\begin{array}{l}\text { MCC-1 } 900 \\
\text { SA } / V= \\
\text { SOLUTE } \\
\text { DAYS }\end{array}$ & $\begin{array}{r}10 / M \\
D I W \\
28\end{array}$ & & & $\begin{array}{l}\text { DATE } 19-\mathrm{Feb}-88 \\
\text { OPERATOR AMA } \\
\text { FACTOR = }\end{array}$ \\
\hline $\begin{array}{l}\text { ICP } L A B \# \\
\text { ICP LAB\# }\end{array}$ & $\begin{array}{l}\text { (GLASS POWDER): } \\
\text { (LEACHATE): }\end{array}$ & $\begin{array}{l}200 \\
413\end{array}$ & & \\
\hline CHEMICAL & ELEM. OXIDE wt? & $\mathrm{Fi}$ & ppm & $\begin{array}{l}\text { NOR. MASS } \\
\text { RELEAS } \mathrm{g} / \mathrm{m} 2\end{array}$ \\
\hline $\begin{array}{l}\mathrm{A} 1203 \\
\mathrm{CaO} \\
\mathrm{SiO} 2 \\
\mathrm{SrO} \\
\mathrm{C} 20\end{array}$ & $\begin{array}{ll}\mathrm{Al} & 12.80 \\
\mathrm{Ca} & 17.20 \\
\mathrm{Si} & 51.80 \\
\mathrm{Sr} & 1.30 \\
\mathrm{Cs} & 0.33\end{array}$ & $\begin{array}{l}0.068 \\
0.123 \\
0.242 \\
0.011 \\
0.003\end{array}$ & $\begin{array}{r}4.000 \\
8.490 \\
15.200 \\
0.825 \\
0.280\end{array}$ & $\begin{array}{l}5.91 \\
6.90 \\
6.27 \\
7.50 \\
9.00\end{array}$ \\
\hline Leachate & $\begin{array}{l}\text { INITIAL } \\
\text { FINAL } \\
\text { Sample \#1490 }\end{array}$ & & $\begin{array}{l}6.11 \\
9.26\end{array}$ & 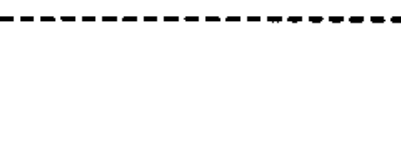 \\
\hline $\begin{array}{l}::::::::: \\
\text { SAMPLE: } \\
\text { MCC-1 } 900 \\
\text { SA/V }= \\
\text { SOLUTE } \\
\text { DAYS }\end{array}$ & $\begin{array}{l}:::::::::::::::: \\
231 P \\
C \quad \\
10 / M \\
\text { DIW } \\
28\end{array}$ & $:::::::$ & : : : : : : : & 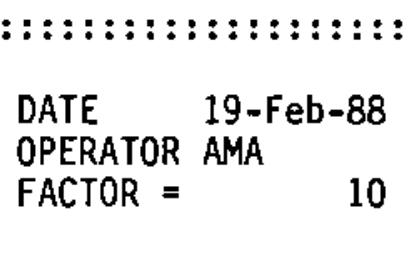 \\
\hline $\begin{array}{l}\text { ICP LAB\# } \\
\text { ICP LAB\# } \\
\text { CHEMICAL }\end{array}$ & $\begin{array}{l}\text { (GLASS POWDER): } \\
\text { (LEACHATE): } \\
\text { ELEM. OXIDE wt\% }\end{array}$ & $\begin{array}{l}201 \\
413\end{array}$ & ppm & $\begin{array}{l}\text { NOR. MASS } \\
\text { RELEAS } \mathrm{g} / \mathrm{m} 2\end{array}$ \\
\hline $\begin{array}{l}\mathrm{Al} 203 \\
\mathrm{CaO} \\
\mathrm{SiO} 2 \\
\mathrm{SrO} \\
\mathrm{Cs} 20\end{array}$ & $\begin{array}{ll}\mathrm{Al} & 13.10 \\
\mathrm{Ca} & 18.60 \\
\mathrm{Si} & 51.50 \\
\mathrm{Sr} & 1.40 \\
\mathrm{Cs} & 0.34\end{array}$ & $\begin{array}{l}0.069 \\
0.133 \\
0.241 \\
0.012 \\
0.003\end{array}$ & $\begin{array}{r}4.150 \\
8.710 \\
15.700 \\
0.851 \\
0.290\end{array}$ & $\begin{array}{l}5.99 \\
6.55 \\
6.51 \\
7.19 \\
9.04\end{array}$ \\
\hline $\mathrm{pH}$ & $\begin{array}{l}\text { INITIAL } \\
\text { FINAL } \\
\text { Sample } \# 1491\end{array}$ & & $\begin{array}{l}6.11 \\
9.19\end{array}$ & \\
\hline
\end{tabular}


CONTINUED. MCC-1 TEST RESULTS

SAMPLE : 232P

MCC -1 90C

$S A / V=10 / M$

DATE 19-Feb-88

SOLUTE DIW

OPERATOR AMA

DAYS

28

FACTOR =

10

ICP LAB\# (GLASS POWDER): 202

ICP LAB\# (LEACHATE): $\quad 413$

CHEMICAL ELEM. OXIDE $w^{\circ} \%$ Fi Ppm RELEAS $\mathrm{g} / \mathrm{m} 2$

\begin{tabular}{llrrrr} 
A 1203 & Al & 13.20 & 0.070 & 3.920 & 5.61 \\
Ca0 & Ca & 18.70 & 0.134 & 8.470 & 6.33 \\
Si02 & Si & 52.00 & 0.243 & 15.000 & 6.16 \\
Sr0 & Sr & 1.40 & 0.012 & 0.818 & 6.91 \\
Cs20 & Cs & 0.34 & 0.003 & 0.280 & 8.73 \\
\hline pH & INITIAL & & & 6.11 & \\
& FINAL & & & 9.11
\end{tabular}

Leachate Sample \#1492

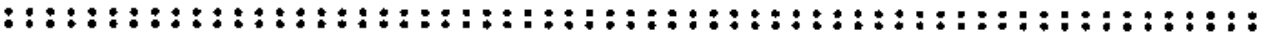

SAMPLE: $233 P$

$M C C-190 \mathrm{C}$

$S A / V=10 / M$

SOLUTE DIW

DAYS 28

DATE 19-Feb-88

OPERATOR AMA

FACTOR =

10

ICP LAB\# (GLASS POWDER): 203

1CP LAB\# (LEACHATE): 413

CHEMICAL ELEM. OXIDE wtq $F i$ ppm RELEAS $\mathrm{g} / \mathrm{m} 2$

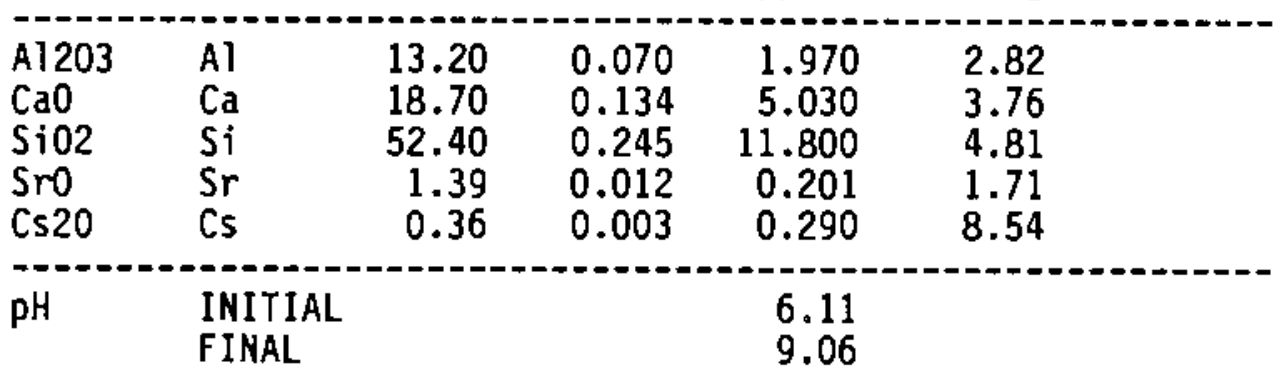

Leachate Sample \$1493 


\section{MCC-3 TEST RESULTS}

The following are copies of sproadsheat files used to calculate the normalized mass rolease from wCC-3 leach testing. The Ppe values listed are difectly fros ICP ( $\mu$ for $C_{a}$ ) analytical results of test leachants. The equation used for the calculatione are provide in the test. Oxide til values are froe ICP analysis of the glass or erystalline product.

\begin{tabular}{|c|c|c|c|c|c|c|c|c|c|}
\hline $\begin{array}{l}\text { WCC-3 } 980 \\
\text { SA/Y = } \\
\text { SOLUE } \\
\text { DAYS }\end{array}$ & $\begin{array}{r}\text { Coge/U- } \\
\text { DII } \\
28\end{array}$ & & & & & $\begin{array}{l}\text { DATE } \\
\text { OPERATOR } \\
\text { FACTOR = }\end{array}$ & ${ }_{2000}^{19-F e b-88}$ & & \\
\hline $\begin{array}{l}\text { ICP LAB: } \\
\text { ICP LAB }\end{array}$ & $\begin{array}{l}\text { (GLASS): } \\
\text { (LEACH): }\end{array}$ & 412, 413 & & .45Y FILT & TRATION & 18A FILTR & RATION & ACID STR & \\
\hline CHEITCA & B日EUT & DXIDE th & $\mathbf{F i}$ & ppa & $\begin{array}{l}\text { NOR. WASS } \\
\text { RELEAS } g / n 2\end{array}$ & PPM & $\begin{array}{l}\text { NOR. WASS } \\
\text { REESS } g / a 2\end{array}$ & PpE & $\begin{array}{l}\text { NOR. MLSS } \\
\text { REEEAS } g / 12\end{array}$ \\
\hline $\begin{array}{l}\text { } 1203 \\
\mathrm{CaO} \\
\mathrm{SiO} \\
\mathrm{SrO} \\
\mathrm{Cs} 20\end{array}$ & $\begin{array}{l}A I \\
C_{a} \\
S i \\
S r \\
C_{8}\end{array}$ & $\begin{array}{r}12.80 \\
17.20 \\
51.80 \\
1.30 \\
6.39\end{array}$ & $\begin{array}{r}0.088 \\
0.123 \\
.242 \\
0.011 \\
0.603\end{array}$ & $\begin{array}{r}2.680 \\
14.100 \\
18.800 \\
1.009 \\
1.546\end{array}$ & $\begin{array}{r}0.019 \\
0.057 \\
0.039 \\
0.045 \\
0.087\end{array}$ & $\begin{array}{r}2.460 \\
13.360 \\
18.460 \\
0.925 \\
0.530\end{array}$ & $\begin{array}{l}0.018 \\
0.054 \\
0.098 \\
0.042 \\
0.686\end{array}$ & $\begin{array}{r}0.038 \\
0.093 \\
0.054 \\
0.060 \\
0.065\end{array}$ & $\begin{array}{l}6.000 \\
.000 \\
0.000 \\
6.000 \\
0.001\end{array}$ \\
\hline \multicolumn{5}{|c|}{ SAMPLE DESIGKXTIOR BY ICP LUO IN PSC/AI7: } & 949 & & 959 & & 1486 \\
\hline $\mathrm{pH}$ & $\begin{array}{l}\text { IMRTINL } \\
\text { FIMLL }\end{array}$ & $\begin{array}{l}8.02 \\
9.49\end{array}$ & & & & & & & \\
\hline
\end{tabular}

\begin{tabular}{|c|c|c|c|c|c|c|c|c|c|}
\hline $\begin{array}{l}\text { WC-9 9AC } \\
\text { SAN = } \\
\text { SDLUTE } \\
\text { DAYS }\end{array}$ & $\begin{array}{r}1780 / 4-1 \\
\text { OIT } \\
28\end{array}$ & & & & & $\begin{array}{l}\text { OATE } \\
\text { OPERATOR } \\
\text { FACTOR = }\end{array}$ & ${ }_{2000}^{19-F o b-8 \theta}$ & & \\
\hline $\begin{array}{l}\text { ICP LAB } \\
\text { ICP LAB }\end{array}$ & $\begin{array}{l}\text { (QLASS): } \\
\text { (LEACH): }\end{array}$ & 412,419 & & $.45 \mathrm{FIL}$ & TRATION & 1BA FILTF & RATYON & ACID STR & \\
\hline CHEIICAL & 日EEvit & DXIDE $=t x$ & $\mathbf{F i}$ & ppa & $\begin{array}{l}\text { NOR. WASS } \\
\text { RAELS g/D2 }\end{array}$ & PPE & $\begin{array}{l}\text { NOR. WSS } \\
\text { REES } g / \triangle 2\end{array}$ & Pp: & $\begin{array}{l}\text { NOR. WUSS } \\
\text { REEAS } g / \|^{2}\end{array}$ \\
\hline $\begin{array}{l}\mathrm{Al}_{203} \\
\mathrm{C}_{20} \\
\mathrm{SiO2} \\
\mathrm{SrO} \\
\mathrm{C}_{2} 20\end{array}$ & $\begin{array}{l}\mathrm{Al} \\
\mathrm{Ca} \\
\mathrm{Si} \\
\mathrm{Sr} \\
\mathrm{Cs}\end{array}$ & $\begin{array}{r}12.86 \\
17.26 \\
51.86 \\
1.36 \\
6.33\end{array}$ & $\begin{array}{r}0.080 \\
0.123 \\
0.262 \\
6.011 \\
0.003\end{array}$ & $\begin{array}{r}2.026 \\
14.286 \\
18.998 \\
1.616 \\
0.546\end{array}$ & $\begin{array}{l}0.019 \\
0.058 \\
.039 \\
0.046 \\
0.087\end{array}$ & $\begin{array}{r}2.506 \\
13.386 \\
18.464 \\
0.933 \\
0.536\end{array}$ & $\begin{array}{r}0.618 \\
0.654 \\
. .638 \\
.042 \\
0.096\end{array}$ & $\begin{array}{l}.085 \\
. .178 \\
.181 \\
.016 \\
.065\end{array}$ & $\begin{array}{l}0.001 \\
0.001 \\
0.000 \\
0.001 \\
0.001\end{array}$ \\
\hline
\end{tabular}

$\begin{array}{lll}\mathrm{PH} & \text { INITINL } & \mathbf{0 . 6 2} \\ & \text { FINNL } & 8.38\end{array}$


CONTINUED. NCC-3 TEST RESUTS

SANPLE: 231A
UCC-3 SAC
SA/Y = $1789 / 4-1$
SELUTE
DAYS

DATE 19-Fab-88

OPERATOR AM

FACTOR =

2866

ICP LABY (CASS): 291

ICP LABF (LENCH) : 412, 413

CHEIICN BEVET OXIDE ItS Fi

\begin{tabular}{|c|c|c|c|c|c|c|c|c|c|}
\hline $\begin{array}{l}\mathrm{Al} 203 \\
\mathrm{C} 20 \\
\mathrm{SiO} \\
\mathrm{SrO} \\
\mathrm{C} 320\end{array}$ & $\begin{array}{l}\text { Al } \\
\text { Ca } \\
\text { Si } \\
\text { Sr } \\
C_{s}\end{array}$ & $\begin{array}{r}13.16 \\
10.66 \\
51.50 \\
1.46 \\
0.34\end{array}$ & $\begin{array}{l}0.689 \\
0.133 \\
0.241 \\
. .012 \\
0.003\end{array}$ & $\begin{array}{r}2.740 \\
14.269 \\
18.960 \\
1.010 \\
0.470\end{array}$ & $\begin{array}{l}0.026 \\
0.053 \\
0.630 \\
0.643 \\
0.073\end{array}$ & $\begin{array}{r}2.546 \\
19.486 \\
18.396 \\
0.782 \\
0.486\end{array}$ & $\begin{array}{l}0.018 \\
0.038 \\
0.038 \\
0.033 \\
0.072\end{array}$ & $\begin{array}{r}0.049 \\
0.169 \\
0.079 \\
0.098 \\
0.065\end{array}$ & $\begin{array}{l}0.000 \\
6.080 \\
6.000 \\
6.000 \\
6.001\end{array}$ \\
\hline
\end{tabular}

SAMPLE DESIGNATIOH BY ICP LDG IN PST/417:

45H FILTRUTIOH

1BA FILTRATION

ACID STRIP

MOR. WUSS NOR. WSS MOR. MSS

R日ELAS g/m2 Ppm REEE/S g/m2 ppa REEAS g/n2

ర51

961

1482

$\begin{array}{cc}\text { PH INITINL } & 6.02 \\ \text { FINAL } & 9.38\end{array}$

\begin{tabular}{|c|c|c|c|c|c|c|c|c|c|}
\hline $\begin{array}{l}\text { LCC-3 } 90 \\
\text { SA } / Y= \\
\text { SOLUTE } \\
\text { DAYS }\end{array}$ & $\begin{array}{r}1780 / \mathrm{N}- \\
\text { DIV } \\
28\end{array}$ & & & & & $\begin{array}{l}\text { OATE } \\
\text { OPERATOR } \\
\text { FACTOR = }\end{array}$ & $\begin{array}{l}19-F a b-88 \\
2906\end{array}$ & & \\
\hline \multirow{2}{*}{$\begin{array}{l}\text { ICP LAB } \\
\text { ICP LAB } \\
\text { CHEIICAL }\end{array}$} & \multirow{2}{*}{$\begin{array}{l}\text { (GASS): } \\
\text { (LEACH): } \\
\text { BEMET }\end{array}$} & \multirow{2}{*}{$\begin{array}{l}201 \\
412,413 \\
\text { OXIDE vtK }\end{array}$} & \multirow[b]{2}{*}{$\mathbf{F i}$} & \multicolumn{2}{|c|}{.45U FILTRATION } & \multicolumn{2}{|c|}{ 18A FILTRATION } & \multicolumn{2}{|c|}{ MCID STRIP } \\
\hline & & & & ppa & $\begin{array}{l}\text { NOR. WASS } \\
\text { RE_ES o/m2 }\end{array}$ & ppa & $\begin{array}{l}\text { MOR. WASS } \\
\text { REEES } \& / \omega 2\end{array}$ & Ppa & $\begin{array}{l}\text { NOR. MSS } \\
\text { REE EAS g/ng }\end{array}$ \\
\hline $\begin{array}{l}\text { Al203 } \\
\text { Ca0 } \\
\text { SiO2 } \\
\text { Sr0 } \\
\text { Cs20 }\end{array}$ & $\begin{array}{l}\mathrm{Al} \\
\mathrm{Ca} \\
\mathrm{Si} \\
\mathrm{Sr} \\
\mathrm{Cs}\end{array}$ & $\begin{array}{r}13.16 \\
18.80 \\
61.50 \\
1.48 \\
6.34\end{array}$ & $\begin{array}{r}0.088 \\
0.133 \\
0.241 \\
0.012 \\
0.693\end{array}$ & $\begin{array}{r}2.860 \\
11.106 \\
18.966 \\
0.861 \\
. .468\end{array}$ & $\begin{array}{r}0.021 \\
0.042 \\
6.039 \\
6.038 \\
6.072\end{array}$ & $\begin{array}{r}2.650 \\
10.160 \\
18.180 \\
6.774 \\
6.440\end{array}$ & $\begin{array}{r}0.019 \\
0.638 \\
0.038 \\
9.633 \\
0.669\end{array}$ & $\begin{array}{l}0.039 \\
0.044 \\
0.022 \\
0.003 \\
0.005\end{array}$ & $\begin{array}{l}0.000 \\
0.606 \\
6.006 \\
6.006 \\
6.601\end{array}$ \\
\hline
\end{tabular}

SRNFIE DESICNRTIUIN 8 Y ICP LOG IR PSL/417:

952

982

1783

PH INITIN $\quad 6.62$


CONTINUED. MKC-3 TEST RESUTS

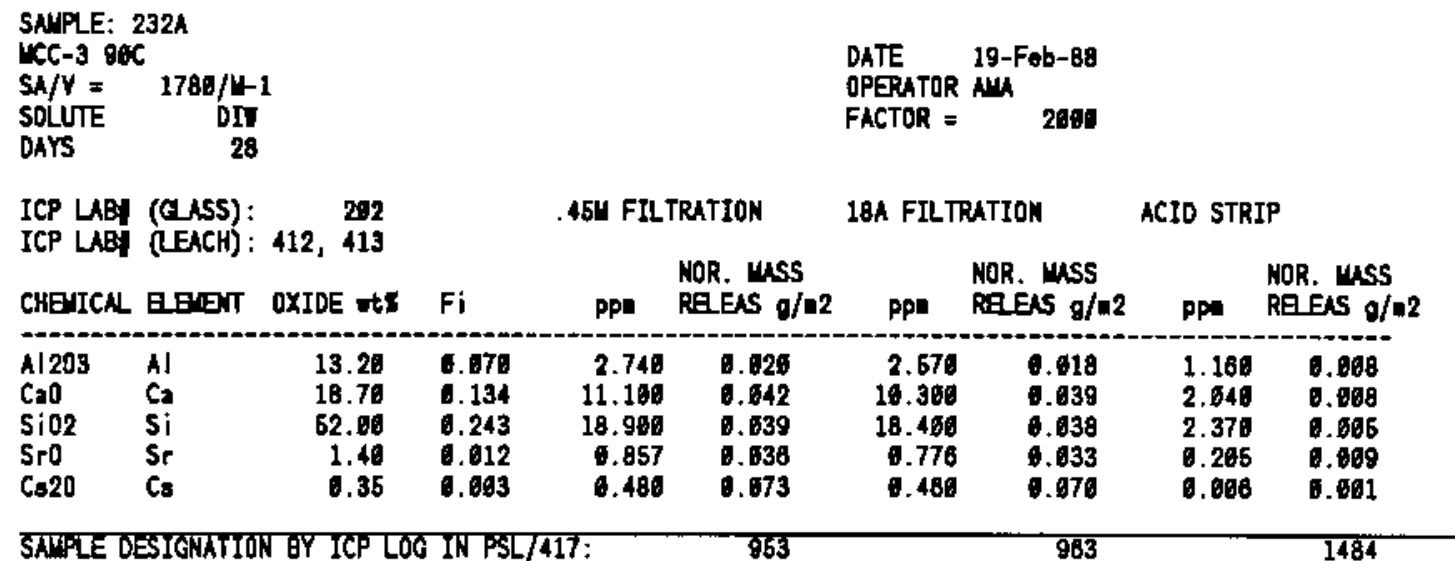

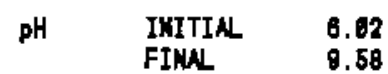

\begin{tabular}{|c|c|c|c|c|c|c|c|c|c|}
\hline $\begin{array}{l}\text { WC-3 OAC } \\
\text { SA/N = } \\
\text { SOLUTE } \\
\text { DAYS }\end{array}$ & 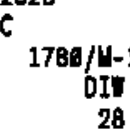 & & & & & $\begin{array}{l}\text { DATE } \\
\text { OPERATOR } \\
\text { FACTOR = }\end{array}$ & $\begin{array}{l}19-F \oplus b-88 \\
2000\end{array}$ & & \\
\hline $\begin{array}{l}\text { ICP LAB } \\
\text { ICP LAB }\end{array}$ & $\begin{array}{l}\text { (CASS): } \\
\text { (LEACH): }\end{array}$ & $\begin{array}{r}262 \\
412,413\end{array}$ & & $.45 \mathrm{VILT}$ & TRATION & \multicolumn{2}{|c|}{ IBA FILTRATION } & \multicolumn{2}{|c|}{ ACID STRIP } \\
\hline CHEIICAL & 日E曰VT & OXIDE th & $\mathrm{Fi}$ & Ppm & $\begin{array}{l}\text { NOR. WASS } \\
\text { REEAS } g / \mathrm{m}^{2}\end{array}$ & PPI & $\begin{array}{l}\text { NOR. MASS } \\
\text { REEAS g/a2 }\end{array}$ & PPA & $\begin{array}{l}\text { NOR. WASS } \\
\text { RELEAS } g / \mathrm{m}^{2}\end{array}$ \\
\hline $\begin{array}{l}\text { A1203 } \\
\text { Ca0 } \\
\text { Si02 } \\
\text { Sro } \\
\text { Cs20 }\end{array}$ & $\begin{array}{l}A 1 \\
C a \\
S i \\
S r \\
C\end{array}$ & $\begin{array}{r}13.29 \\
18.79 \\
62.09 \\
1.40 \\
0.36\end{array}$ & $\begin{array}{r}0.070 \\
.134 \\
.243 \\
.012 \\
0.093\end{array}$ & $\begin{array}{r}2.640 \\
16.969 \\
18.390 \\
6.931 \\
6.470\end{array}$ & $\begin{array}{r}0.018 \\
0.041 \\
0.638 \\
.035 \\
.071\end{array}$ & $\begin{array}{r}2.460 \\
0.826 \\
17.460 \\
6.738 \\
0.470\end{array}$ & $\begin{array}{r}6.017 \\
0.037 \\
6.036 \\
6.031 \\
0.071\end{array}$ & $\begin{array}{l}0.119 \\
0.224 \\
0.232 \\
0.022 \\
0.805\end{array}$ & $\begin{array}{l}0.001 \\
0.001 \\
0.006 \\
0.001 \\
6.001\end{array}$ \\
\hline
\end{tabular}

$\begin{array}{ll}\text { PH INITINL } & 0.62 \\ \text { FINAL } & 9.65\end{array}$


CONTINUED. WEC-3 TEST RESULS

SALPE: 233 A
WCE-3 $99 \mathrm{C}$
SA/N $=$
SOLUTE
DAYS

OATE $\quad 19-\mathrm{Fab}-88$

OPERATOR NMA

FACTOR $=\quad 2098$

ICP LAO (GNSS): 263

ICP LAP (LEACH) : 112, 113

45U FILTRATION I8A FILTRATION ACID STRIP

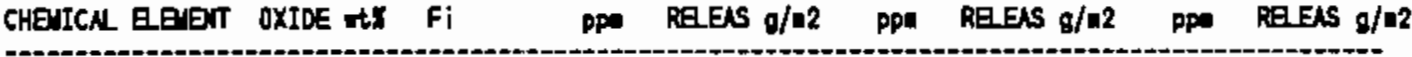

\begin{tabular}{|c|c|c|c|c|c|c|c|c|c|}
\hline $\begin{array}{l}\text { Al203 } \\
\text { C20 } \\
\text { SiO2 } \\
\text { Sro } \\
\text { Cs2D }\end{array}$ & $\begin{array}{l}A l \\
C_{9} \\
S i \\
S r \\
C_{0}\end{array}$ & $\begin{array}{r}13.20 \\
18.70 \\
52.49 \\
1.39 \\
1.36\end{array}$ & $\begin{array}{r}0.070 \\
0.134 \\
0.245 \\
0.012 \\
0.003\end{array}$ & $\begin{array}{r}2.060 \\
8.460 \\
19.460 \\
1.463 \\
1.060\end{array}$ & $\begin{array}{l}0.015 \\
8.032 \\
0.046 \\
0.026 \\
0.147\end{array}$ & $\begin{array}{r}1.896 \\
7.616 \\
19.106 \\
7.396 \\
0.016\end{array}$ & $\begin{array}{r}0.014 \\
0.028 \\
0.039 \\
.017 \\
0.136\end{array}$ & $\begin{array}{l}1.086 \\
0.058 \\
0.028 \\
0.607 \\
0.085\end{array}$ & $\begin{array}{l}0.006 \\
0.000 \\
0.000 \\
6.080 \\
0.001\end{array}$ \\
\hline
\end{tabular}

SALPEF DESIGNAION BY ICP LOG INPSL/A17:

955

965

1486

$\begin{array}{lll}\text { pH } & \text { INITIN } & 6.92 \\ & \text { FINAL } & 0.47\end{array}$

\begin{tabular}{|c|c|c|c|c|c|c|c|c|c|}
\hline $\begin{array}{l}\text { WCC-3 } 90 C \\
\text { SA/N = } \\
\text { SOLUTE } \\
\text { DAYS }\end{array}$ & $\begin{array}{r}\text { C } \\
1780 / 4- \\
\text { DIV }\end{array}$ & & & & & $\begin{array}{l}\text { DATE } \\
\text { OPERTTOR } \\
\text { FACTOR = }\end{array}$ & $\begin{array}{l}19-F_{0 b}-8 B \\
N_{A} \quad 2009\end{array}$ & & \\
\hline $\begin{array}{l}\text { ICP LAOI } \\
\text { ICP LAB| }\end{array}$ & $\begin{array}{l}\text { (GASS) : } \\
\text { (LEACH) : }\end{array}$ & $412, \begin{array}{r}243 \\
113\end{array}$ & & $.454 \mathrm{FIL}$ & TRATION & 18A FILTR & RATION & ACID STR & \\
\hline & 日ค曰曰T & OXIDE & $\mathbf{F i}$ & PpM & $\begin{array}{l}\text { NOR, WASS } \\
\text { REEAS o/n2 }\end{array}$ & PPI & $\begin{array}{l}\text { MER. MASS } \\
\text { REEAS } g /{ }^{2} 2\end{array}$ & PPI & $\begin{array}{l}\text { KOR. WLS } \\
\text { REEESS g/०2 }\end{array}$ \\
\hline $\begin{array}{l}\text { Al203 } \\
\mathrm{CaO} \\
\mathrm{Si02} \\
\mathrm{SrO} \\
\mathrm{C}=20\end{array}$ & $\begin{array}{l}\text { Al } \\
C_{2} \\
S i \\
\text { Sr } \\
\text { Cs }\end{array}$ & $\begin{array}{r}13.20 \\
18.70 \\
52.49 \\
1.39 \\
6.36\end{array}$ & $\begin{array}{l}0.076 \\
0.134 \\
6.245 \\
.012 \\
.063\end{array}$ & $\begin{array}{r}1.920 \\
8.896 \\
19.896 \\
9.476 \\
1.098\end{array}$ & $\begin{array}{l}0.014 \\
0.633 \\
0.046 \\
0.026 \\
0.147\end{array}$ & $\begin{array}{r}1.746 \\
7.976 \\
10.100 \\
0.494 \\
6.989\end{array}$ & $\begin{array}{r}0.012 \\
0.030 \\
.039 \\
0.017 \\
.141\end{array}$ & $\begin{array}{l}0.066 \\
0.042 \\
0.017 \\
0.005 \\
0.006\end{array}$ & $\begin{array}{l}0.000 \\
0.006 \\
0.000 \\
6.006 \\
0.001\end{array}$ \\
\hline
\end{tabular}

SKWPLE OESIGRATION BY ICP LOO IN PSL/417:

858

$\$ 88$

1487

$\begin{array}{lll}\text { pH } & \text { INITIN } & \mathbf{6 . 6 2} \\ & \text { FINNL } & \mathbf{0 . 6 2}\end{array}$


CONTIMUED. KEC-3 TEST RESULTS

\begin{tabular}{|c|c|c|c|c|c|c|c|c|c|}
\hline $\begin{array}{l}\text { UCC-3 Sac } \\
\text { SA/N = } \\
\text { SOLUTE } \\
\text { DAYS }\end{array}$ & $\begin{array}{r}1780 / \mathrm{L}- \\
\text { DI } \\
28\end{array}$ & & & & & $\begin{array}{l}\text { DATE } \\
\text { OPERATOR } \\
\text { FACTOR = }\end{array}$ & ${ }_{24}^{19-F o b-88}$ & & \\
\hline \multirow{2}{*}{$\begin{array}{l}\text { ICP LABY } \\
\text { ICP LABY } \\
\text { CHEICA }\end{array}$} & \multirow{2}{*}{$\begin{array}{l}\text { (CLAS): } \\
\text { (LEACH) : } \\
\text { BEMT }\end{array}$} & \multirow{2}{*}{$\begin{array}{l}200,491 \\
412,413 \\
\text { OXIDE TtS }\end{array}$} & \multirow[b]{2}{*}{$\mathrm{Fi}$} & \multicolumn{2}{|c|}{.45U FILTRATION } & \multicolumn{2}{|c|}{ 18A FILTRATION } & \multicolumn{2}{|c|}{ ACID STRIP } \\
\hline & & & & ppa & $\begin{array}{l}\text { NOR. WASS } \\
\text { RELES \&/.2 }\end{array}$ & PpA & $\begin{array}{l}\text { NOR. WASS } \\
\text { REESS o/m2 }\end{array}$ & Ppe & $\begin{array}{l}\text { NOR. USS } \\
\text { PRE ENS g/=2 }\end{array}$ \\
\hline $\begin{array}{l}\text { Al203 } \\
\mathrm{CaO} \\
\mathrm{SiO} \\
\mathrm{SrO} \\
\mathrm{C} 20\end{array}$ & $\begin{array}{l}A 1 \\
C_{a} \\
S i \\
S r \\
C_{s}\end{array}$ & $\begin{array}{r}12.90 \\
18.68 \\
52.10 \\
1.45 \\
0.35\end{array}$ & $\begin{array}{l}.060 \\
0.192 \\
0.244 \\
0.012 \\
0.063\end{array}$ & $\begin{array}{r}2.439 \\
9.640 \\
19.060 \\
6.620 \\
0.660\end{array}$ & $\begin{array}{l}0.618 \\
0.636 \\
0.038 \\
0.026 \\
0.128\end{array}$ & $\begin{array}{r}2.250 \\
8.470 \\
18.390 \\
6.532 \\
6.810\end{array}$ & $\begin{array}{l}6.016 \\
6.032 \\
6.039 \\
.022 \\
6.123\end{array}$ & $\begin{array}{l}0.086 \\
0.025 \\
0.014 \\
0.004 \\
0.005\end{array}$ & $\begin{array}{l}0.000 \\
6.060 \\
6.060 \\
6.060 \\
6.061\end{array}$ \\
\hline
\end{tabular}

SADPLE OESIGNATION BY ICP LOO IN PSL/417:

$\$ 57$

987

1488

$\begin{array}{lll}\mathrm{pH} & \text { INITINLL } & 0.02 \\ & \text { FINAL } & 9.46\end{array}$

\begin{tabular}{|c|c|c|c|c|c|c|c|c|c|}
\hline $\begin{array}{l}\text { ICC-3 } 000 \\
\text { SAN = } \\
\text { SOLUTE } \\
\text { DAYS }\end{array}$ & $\begin{array}{r}1780 / 4- \\
\text { DI } \\
28\end{array}$ & & & & & $\begin{array}{l}\text { DATE } \\
\text { OPGRATOR } \\
\text { FACTOR = }\end{array}$ & $\stackrel{1 M}{19-F o b-80}_{2080}$ & & \\
\hline \multirow{2}{*}{$\begin{array}{l}\text { ICP LAB } \\
\text { ICP LAB } \\
\text { CHEIICAL }\end{array}$} & \multirow{2}{*}{$\begin{array}{l}\text { (CLSS) : } \\
\text { (LEHCH) : } \\
\text { 日EDIT }\end{array}$} & \multirow{2}{*}{$\begin{array}{l}206,491 \\
412,413 \\
\text { OXIDE }+t \times\end{array}$} & \multirow[b]{2}{*}{$\mathrm{Fi}$} & \multicolumn{2}{|c|}{ 45U FILTRATION } & \multicolumn{2}{|c|}{ 18A FILTRATION } & \multicolumn{2}{|c|}{ ACID STRIP } \\
\hline & & & & ppa & $\begin{array}{l}\text { MDR. WASS } \\
\text { REEAS } \mathrm{g} / \mathrm{m} 2\end{array}$ & Ppa & $\begin{array}{l}\text { NOR. WASS } \\
\text { REIEAS g/n2 }\end{array}$ & PpA & $\begin{array}{l}\text { NOR. WSS } \\
\text { REESS } g / m 2\end{array}$ \\
\hline $\begin{array}{l}\text { Al203 } \\
\text { CaO } \\
\text { Sig2 } \\
\text { SrO } \\
\text { Ca20 }\end{array}$ & $\begin{array}{l}\text { Al } \\
C_{a} \\
S i \\
\text { Sr } \\
C_{0}\end{array}$ & $\begin{array}{r}12.90 \\
18.50 \\
52.10 \\
1.45 \\
1.35\end{array}$ & $\begin{array}{l}0.068 \\
0.132 \\
0.244 \\
0.012 \\
.063\end{array}$ & $\begin{array}{r}2.490 \\
8.830 \\
19.260 \\
6.635 \\
0.860\end{array}$ & $\begin{array}{l}0.618 \\
0.037 \\
0.038 \\
0.028 \\
0.138\end{array}$ & $\begin{array}{r}2.280 \\
8.710 \\
19.500 \\
6.548 \\
0.810\end{array}$ & $\begin{array}{l}0.017 \\
0.093 \\
0.638 \\
0.622 \\
0.123\end{array}$ & $\begin{array}{l}0.606 \\
0.654 \\
0.006 \\
0.066 \\
0.005\end{array}$ & $\begin{array}{l}6.000 \\
6.060 \\
6.080 \\
6.000 \\
6.081\end{array}$ \\
\hline
\end{tabular}

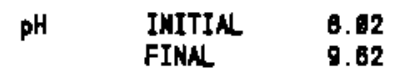


CONTINUED. MCC-3 TEST RESULTS

The following a summary of normalized mass releases from duplicate MCC-3 leach tests. The $0.45 \mu \mathrm{m}$ are normalize release values from ICP (AA for Cs) analytical results for the leachants filter through a $0.45 \mu \mathrm{m}$ filter. The 18 Ang. values are normalize release from 18 angstrom filtered samples. The A.S are from the acid strip of the leach vessel after the test to determine if signifcant amount of material plated to the leaching vessel.

NORMALIZEO MASS RELEASE, $\mathrm{g} / \mathrm{m}^{2}$

\begin{tabular}{|c|c|c|c|c|c|c|}
\hline LEMENT & $\begin{array}{l}230 \mathrm{~A}:::: \\
.45 \mathrm{mic} .\end{array}$ & $\begin{array}{l}::::: \\
\text { Ang. }\end{array}$ & : : : : : & $\begin{array}{l}230 \mathrm{~B}:::: \\
.45 \mathrm{mic}\end{array}$ & $\begin{array}{l}\text { : : : : } \\
\text { Ang. }\end{array}$ & $\begin{array}{l}:::::: \\
S\end{array}$ \\
\hline 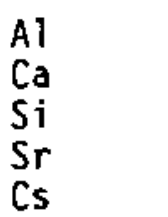 & $\begin{array}{l}0.019 \\
0.057 \\
0.039 \\
0.045 \\
0.087\end{array}$ & $\begin{array}{l}0.018 \\
0.054 \\
0.038 \\
0.042 \\
0.085\end{array}$ & $\begin{array}{l}0.000 \\
0.000 \\
0.000 \\
0.000 \\
0.001\end{array}$ & $\begin{array}{l}0.019 \\
0.058 \\
0.039 \\
0.046 \\
0.087\end{array}$ & $\begin{array}{l}0.018 \\
0.054 \\
0.038 \\
0.042 \\
0.085\end{array}$ & $\begin{array}{l}0 . \\
0 . \\
0 . \\
0 .\end{array}$ \\
\hline
\end{tabular}

\begin{tabular}{|c|c|c|c|c|c|c|}
\hline ELEMENT & $\begin{array}{l}\text { 231A::::: } \\
.45 \mathrm{mic} .\end{array}$ & Ang. & : & $\begin{array}{l}231 \mathrm{~B}::: \\
.45 \mathrm{mic}\end{array}$ & Ang & $::$ \\
\hline$i$ & $\begin{array}{l}0.020 \\
0.053 \\
0.039 \\
0.043 \\
0.073\end{array}$ & $\begin{array}{l}0.018 \\
0.039 \\
0.038 \\
0.033 \\
0.072\end{array}$ & $\begin{array}{l}0.000 \\
0.000 \\
0.000 \\
0.000 \\
0.001\end{array}$ & $\begin{array}{l}0.021 \\
0.042 \\
0.039 \\
0.036 \\
0.072\end{array}$ & $\begin{array}{l}0.019 \\
0.038 \\
0.038 \\
0.033 \\
0.069\end{array}$ & $\begin{array}{l}0.0 \\
0.0 \\
0.0 \\
0.0 \\
0.0\end{array}$ \\
\hline
\end{tabular}

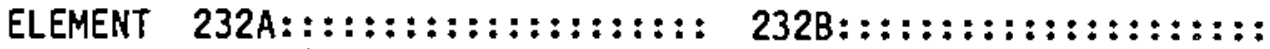

.45 mic. 18 Ang. A.S .45 mic. 18 Ang. A.S

$\begin{array}{lllllll}\text { A] } & 0.020 & 0.018 & 0.008 & 0.019 & 0.017 & 0.001 \\ \text { Ca } & 0.042 & 0.039 & 0.008 & 0.041 & 0.037 & 0.001 \\ \text { Si } & 0.039 & 0.038 & 0.005 & 0.038 & 0.036 & 0.000 \\ \text { Sr } & 0.036 & 0.033 & 0.009 & 0.035 & 0.031 & 0.001 \\ \text { Cs } & 0.073 & 0.070 & 0.001 & 0.071 & 0.071 & 0.001\end{array}$


CONTINUED. MCC-3 TEST RESULTS

NORMALIZEO MASS RELEASE, $g / \mathrm{m}^{2}$

\begin{tabular}{|c|c|c|c|c|c|c|}
\hline ELEMENT & $\begin{array}{l}233 \mathrm{~A}: \mathrm{:}: \mathrm{:} \\
.45 \mathrm{mic} .\end{array}$ & $\begin{array}{l}::::: \\
\text { Ang. }\end{array}$ & $:::$ & $\begin{array}{l}\text { 233B: : : : } \\
.45 \mathrm{mic}\end{array}$ & $\begin{array}{l}::::: \\
\text { Ang. }\end{array}$ & $\begin{array}{l}::::: \\
S\end{array}$ \\
\hline $\begin{array}{l}\mathrm{Al} \\
\mathrm{Ca} \\
\mathrm{Si} \\
\mathrm{Sr} \\
\mathrm{Cs}\end{array}$ & $\begin{array}{l}0.015 \\
0.032 \\
0.040 \\
0.020 \\
0.147\end{array}$ & $\begin{array}{l}0.014 \\
0.028 \\
0.039 \\
0.017 \\
0.138\end{array}$ & $\begin{array}{l}0.000 \\
0.000 \\
0.000 \\
0.000 \\
0.001\end{array}$ & $\begin{array}{l}0.014 \\
0.033 \\
0.040 \\
0.020 \\
0.147\end{array}$ & $\begin{array}{l}0.012 \\
0.030 \\
0.039 \\
0.017 \\
0.141\end{array}$ & $\begin{array}{l}0.000 \\
0.000 \\
0.000 \\
0.000 \\
0.001\end{array}$ \\
\hline
\end{tabular}

\begin{tabular}{|c|c|c|c|c|c|c|}
\hline ELEMENT & $\begin{array}{l}240 \mathrm{~A}::::: \\
.45 \mathrm{mic} .\end{array}$ & $\begin{array}{l}:::::: \text { : } \\
\text { Ang. }\end{array}$ & & $\begin{array}{l}240 \mathrm{~B}:::: \\
.45 \text { mic. }\end{array}$ & $\begin{array}{l}:::: \\
\text { Ang. }\end{array}$ & $:::$ : \\
\hline $\begin{array}{l}\mathrm{Al} \\
\mathrm{Ca} \\
\mathrm{Si} \\
\mathrm{Sr} \\
\mathrm{Cs}\end{array}$ & $\begin{array}{l}0.018 \\
0.036 \\
0.039 \\
0.025 \\
0.129\end{array}$ & $\begin{array}{l}0.016 \\
0.032 \\
0.038 \\
0.022 \\
0.123\end{array}$ & $\begin{array}{l}0.000 \\
0.000 \\
0.000 \\
0.000 \\
0.001\end{array}$ & $\begin{array}{l}0.018 \\
0.037 \\
0.039 \\
0.026 \\
0.130\end{array}$ & $\begin{array}{l}0.017 \\
0.033 \\
0.038 \\
0.022 \\
0.123\end{array}$ & $\begin{array}{l}0.000 \\
0.000 \\
0.000 \\
0.000 \\
0.001\end{array}$ \\
\hline
\end{tabular}


CONTINUED. MCC-3 TEST RESULTS

The following are the average nomalized release values, standard deviations, and percent relative standard deviations (\%RSD) for the duplicate MCC-3 tests for the 0.45 um and 18 angstrom results. Values list as ERR indicate that the duplicates had the same value and no standard deviation could be calculated.

\begin{tabular}{|c|c|c|c|c|c|}
\hline AVERAGES & $\frac{0.45 \mathrm{um}}{230}$ & $\begin{array}{l}\text { NORMAL } \\
231\end{array}$ & $\begin{array}{l}\text { ED MASS } \\
232\end{array}$ & $\begin{array}{c}\text { RELEASE, } \\
233\end{array}$ & $\begin{array}{l}g / m^{2} \\
236 / 240\end{array}$ \\
\hline $\begin{array}{l}\text { Al } \\
\text { Ca } \\
\text { Si } \\
\text { Sr } \\
\text { Cs }\end{array}$ & $\begin{array}{l}0.019 \\
0.058 \\
0.039 \\
0.046 \\
0.087\end{array}$ & $\begin{array}{l}0.020 \\
0.048 \\
0.039 \\
0.039 \\
0.073\end{array}$ & $\begin{array}{l}0.019 \\
0.041 \\
0.038 \\
0.036 \\
0.072\end{array}$ & $\begin{array}{l}0.014 \\
0.032 \\
0.040 \\
0.020 \\
0.147\end{array}$ & $\begin{array}{l}0.018 \\
0.037 \\
0.039 \\
0.026 \\
0.130\end{array}$ \\
\hline
\end{tabular}

\section{STANDARD DEVIATION}

\begin{tabular}{lrrrrr}
\hline Al & 0.00007 & 0.00043 & 0.00036 & 0.00050 & 0.00022 \\
Ca & 0.00020 & 0.00583 & 0.00037 & 0.00080 & 0.00036 \\
Si & 0.00010 & 0.00000 & 0.00062 & 0.00041 & 0.00021 \\
Sr & 0.00023 & 0.00315 & 0.00055 & 0.00015 & 0.00031 \\
Cs & ERR & 0.00078 & 0.00076 & 0.00000 & 0.00076
\end{tabular}

\begin{tabular}{lrrrrr} 
\%RSD & & & & & \\
\hline AT & 0.38 & 2.14 & 1.86 & 3.52 & 1.22 \\
Ca & 0.35 & 12.25 & 0.91 & 2.48 & 0.98 \\
Si & 0.27 & 0.00 & 1.61 & 1.02 & 0.52 \\
Sr & 0.50 & 7.96 & 1.54 & 0.75 & 1.20 \\
Cs & ERR & 1.08 & 1.05 & 0.00 & 0.58
\end{tabular}

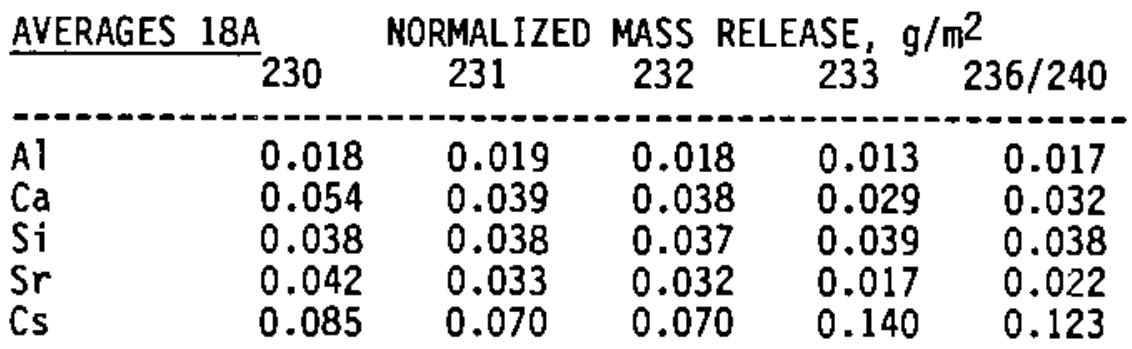

STANDARD DEVIATION

\begin{tabular}{lrllll}
\hline Al & 0.00015 & 0.00040 & 0.00061 & 0.00054 & 0.00011 \\
Ca & ERR & 0.00056 & 0.00090 & 0.00067 & 0.00045 \\
Si & ERR & 0.00021 & 0.00103 & 0.00000 & 0.00021 \\
Sr & 0.00018 & 0.00017 & 0.00084 & 0.00017 & 0.00033 \\
CS & ERR & 0.00156 & 0.00076 & 0.00147 & 0.00000
\end{tabular}

$\begin{array}{lrllll}\text { 7.RSD } & & & & \\ \text { AI } & 0.81 & 2.12 & 3.42 & 4.13 & 0.66 \\ \text { Ca } & \text { ERR } & 1.46 & 2.39 & 2.31 & 1.40 \\ \text { Si } & \text { ERR } & 0.55 & 2.79 & 0.00 & 0.54 \\ \text { Sr } & 0.43 & 0.51 & 2.65 & 1.00 & 1.48 \\ \text { Cs } & \text { ERR } & 2.22 & 1.08 & 1.05 & 0.00\end{array}$


LCC-LOO TEST RESUTS

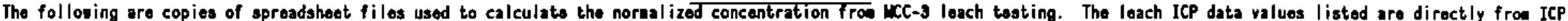

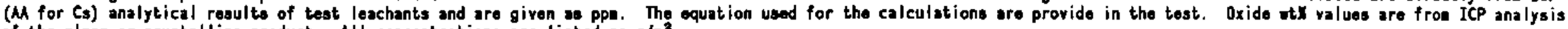
of the glass or crystalline product. All concontrations are listed as $g / \mathrm{m}^{3}$.

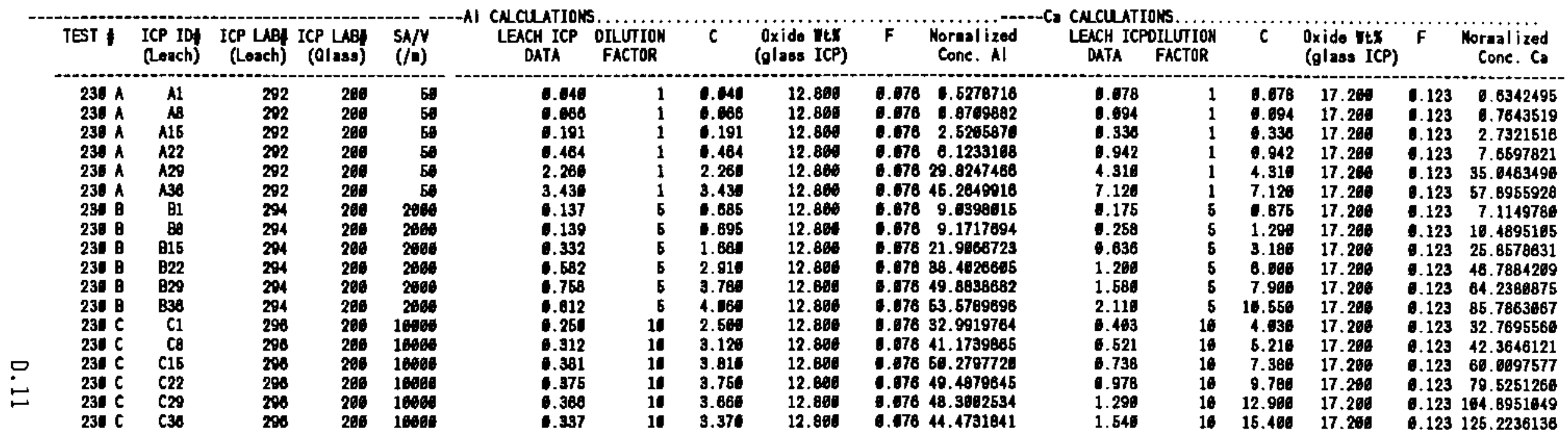

\begin{tabular}{|c|c|c|c|c|c|c|c|c|c|c|c|c|c|c|c|c|}
\hline TEST & $\begin{array}{l}\text { ICP ID) } \\
\text { (Leach) }\end{array}$ & $\begin{array}{r}\text { ICP LABY } \\
\text { (Leach) }\end{array}$ & $\begin{array}{l}\text { ICP LABY } \\
\text { (Glass) }\end{array}$ & $\begin{array}{l}S N / V \\
(/ H)\end{array}$ & $\begin{array}{l}\text { LEACH ICP } \\
\text { DATA }\end{array}$ & $\begin{array}{l}\text { DILUTION } \\
\text { FACTOR }\end{array}$ & $\ddot{c}$ & Oxlase ICP) & $\mathbf{F}$ & $\begin{array}{l}\text { Mornal ized } \\
\text { Conc. Fe }\end{array}$ & $\begin{array}{l}\text { LEACH ICP } \\
\text { DATA }\end{array}$ & $\begin{array}{l}\text { FILUTIOA } \\
\text { FACTOR }\end{array}$ & i & $\begin{array}{l}\text { Oxide its } \\
\text { (glass ICP) }\end{array}$ & $\mathbf{F}$ & $\begin{array}{l}\text { Nornal ized } \\
\text { Conc. Ho }\end{array}$ \\
\hline 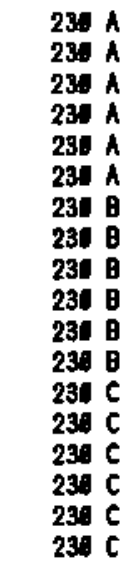 & $\begin{array}{r}A 1 \\
A B \\
A 15 \\
A 22 \\
A 29 \\
A 36 \\
B 1 \\
83 \\
815 \\
822 \\
829 \\
836 \\
\text { C1 } \\
\text { C8 } \\
\text { C15 } \\
\text { C22 } \\
\text { C29 } \\
\text { C36 }\end{array}$ & $\begin{array}{l}292 \\
202 \\
292 \\
202 \\
292 \\
202 \\
294 \\
294 \\
294 \\
294 \\
294 \\
294 \\
290 \\
296 \\
296 \\
296 \\
296 \\
296\end{array}$ & 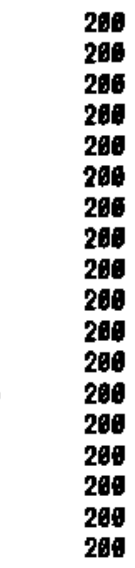 & 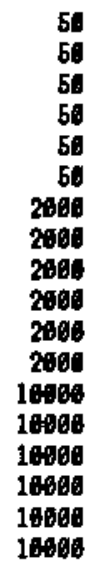 & 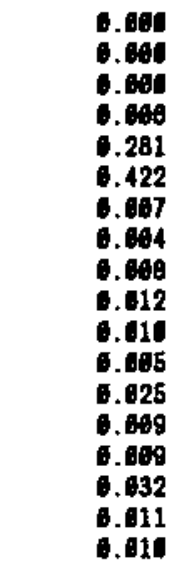 & $\begin{array}{r}1 \\
1 \\
1 \\
1 \\
1 \\
1 \\
5 \\
5 \\
5 \\
5 \\
5 \\
5 \\
10 \\
10 \\
10 \\
10 \\
10 \\
10\end{array}$ & 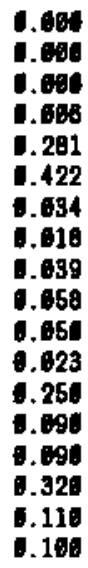 & $\begin{array}{l}4.300 \\
4.300 \\
4.300 \\
4.309 \\
4.300 \\
4.300 \\
4.300 \\
4.360 \\
4.360 \\
4.360 \\
4.360 \\
4.369 \\
4.360 \\
4.360 \\
4.300 \\
4.360 \\
4.390 \\
4.300\end{array}$ & 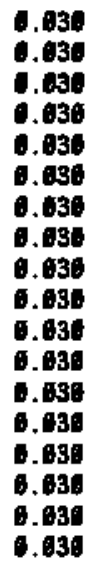 & 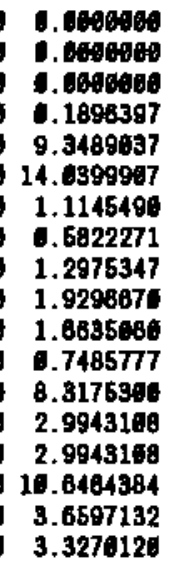 & 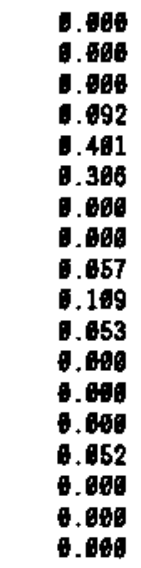 & $\begin{array}{r}1 \\
1 \\
1 \\
1 \\
1 \\
1 \\
5 \\
5 \\
5 \\
5 \\
5 \\
5 \\
10 \\
10 \\
10 \\
10 \\
10 \\
10\end{array}$ & 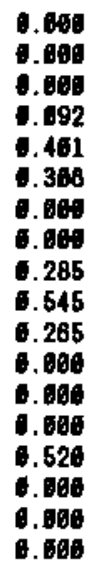 & 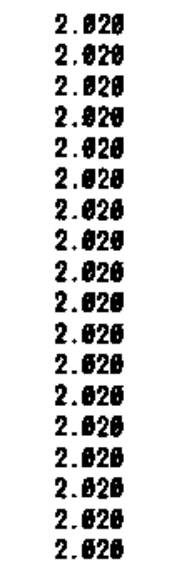 & $\begin{array}{l}6.012 \\
0.012 \\
0.012 \\
0.012 \\
0.012 \\
0.012 \\
0.012 \\
0.012 \\
0.012 \\
0.012 \\
0.012 \\
0.012 \\
0.012 \\
0.012 \\
0.012 \\
0.012 \\
0.012 \\
0.012\end{array}$ & 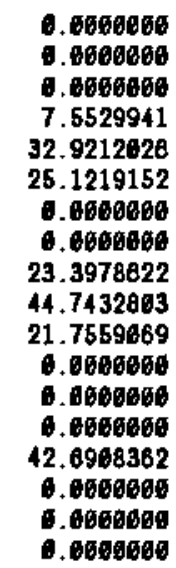 \\
\hline
\end{tabular}


CONTIMED. LCC-HOD TEST RESULTS

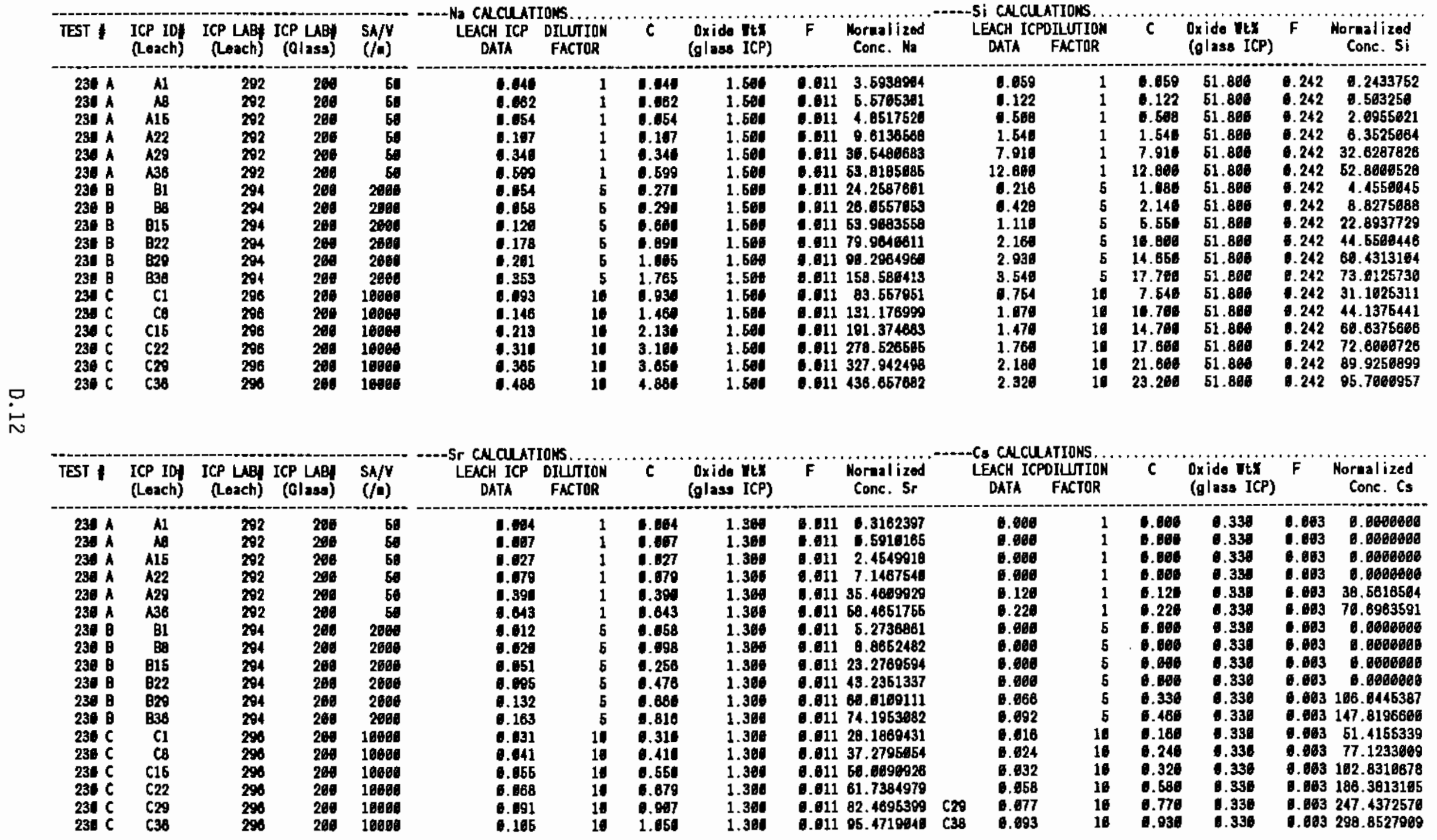


CONTINED. WCC-WDD TEST RESUTS

\begin{tabular}{|c|c|c|c|c|c|c|c|c|c|c|c|c|c|c|c|c|}
\hline TEST & $\begin{array}{l}\text { ICP IOS } \\
\text { (Leach) }\end{array}$ & $\begin{array}{l}\text { ICP LABS } \\
\text { (Leach) }\end{array}$ & $\begin{array}{l}\text { ICP LAB } \\
\text { (Olaso) }\end{array}$ & $\begin{array}{l}S A / N \\
(/ D)\end{array}$ & $\begin{array}{l}\text { LEACH ICP } \\
\text { DATA }\end{array}$ & $\begin{array}{l}\text { DIUUTION } \\
\text { FACTOR }\end{array}$ & c & $\begin{array}{l}\text { Oxide It: } \\
\text { (glass ICP) }\end{array}$ & $F$ & $\begin{array}{l}\text { Horealized } \\
\text { Conc. Al }\end{array}$ & $\begin{array}{l}\text { LEACH ICP } \\
\text { DATA }\end{array}$ & $\begin{array}{l}\text { DILUTION } \\
\text { FACTOR }\end{array}$ & c & $\begin{array}{l}\text { Oxide tis } \\
\text { (glass ICP) }\end{array}$ & $\mathrm{F}$ & $\begin{array}{c}\text { Norualized } \\
\text { Conc. Ca }\end{array}$ \\
\hline 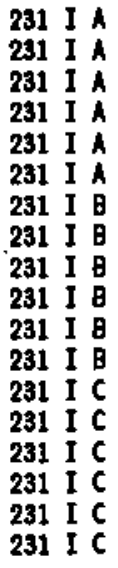 & $\begin{array}{l}A 2 \\
A 9 \\
A 16 \\
A 23 \\
A 31 \\
A 37 \\
B 2 \\
B 9 \\
816 \\
823 \\
839 \\
B 37 \\
C 2 \\
C 9 \\
C 16 \\
C 23 \\
C 39 \\
C 37\end{array}$ & $\begin{array}{l}292 \\
292 \\
292 \\
292 \\
292 \\
292 \\
294 \\
294 \\
294 \\
294 \\
294 \\
294 \\
296 \\
296 \\
296 \\
298 \\
290 \\
298\end{array}$ & $\begin{array}{l}201 \\
201 \\
201 \\
201 \\
201 \\
201 \\
201 \\
201 \\
201 \\
201 \\
201 \\
201 \\
201 \\
201 \\
201 \\
201 \\
201 \\
201\end{array}$ & 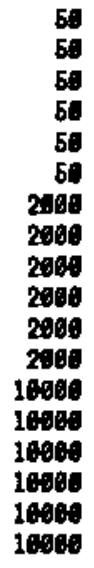 & $\begin{array}{l}1.049 \\
0.125 \\
. .368 \\
.689 \\
2.836 \\
3.416 \\
. .184 \\
. .149 \\
. .351 \\
. .626 \\
. .775 \\
. .811 \\
. .221 \\
. .316 \\
. .386 \\
. .372 \\
. .346 \\
. .326\end{array}$ & $\begin{array}{r}1 \\
1 \\
1 \\
1 \\
1 \\
1 \\
5 \\
5 \\
5 \\
5 \\
5 \\
5 \\
10 \\
10 \\
10 \\
10 \\
10 \\
10\end{array}$ & $\begin{array}{r}0.049 \\
1.125 \\
1.38 \\
6.689 \\
2.83 \\
3.41 \\
1.62 \\
0.745 \\
1.755 \\
3.1 \\
3.675 \\
4.655 \\
2.21 \\
3.18 \\
3.8 \\
3.72 \\
3.48 \\
3.26\end{array}$ & $\begin{array}{l}13.1 \\
13.1 \\
13.1 \\
13.1 \\
13.1 \\
13.1 \\
13.1 \\
13.1 \\
13.1 \\
13.1 \\
13.1 \\
13.1 \\
13.1 \\
13.1 \\
13.1 \\
13.1 \\
13.1 \\
13.1\end{array}$ & 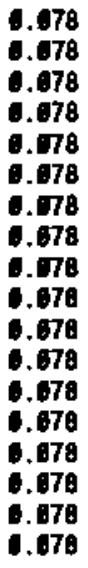 & 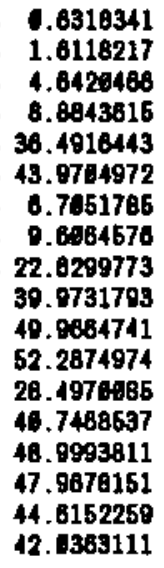 & $\begin{array}{r}1.133 \\
6.298 \\
0.684 \\
1.388 \\
6.32 \\
6.97 \\
0.169 \\
1.248 \\
0.621 \\
1.179 \\
1.49 \\
1.91 \\
1.388 \\
. .589 \\
0.699 \\
1.839 \\
0.972 \\
1.1\end{array}$ & $\begin{array}{r}1 \\
1 \\
1 \\
1 \\
1 \\
1 \\
5 \\
5 \\
5 \\
5 \\
5 \\
5 \\
10 \\
10 \\
10 \\
10 \\
10 \\
10\end{array}$ & $\begin{array}{r}6.193 \\
6.209 \\
6.684 \\
1.369 \\
5.32 \\
8.97 \\
6.54 \\
1.2 \\
3.165 \\
5.85 \\
7.46 \\
0.55 \\
3.88 \\
5 \\
6.99 \\
6.39 \\
0.72 \\
11\end{array}$ & $\begin{array}{l}18.8 \\
18.8 \\
18.6 \\
18.6 \\
18.6 \\
18.6 \\
18.6 \\
18.6 \\
18.6 \\
18.6 \\
18.6 \\
18.6 \\
18.6 \\
18.6 \\
18.6 \\
18.6 \\
18.6 \\
18.6\end{array}$ & $\begin{array}{l}0.133 \\
0.133 \\
0.133 \\
0.133 \\
0.133 \\
0.133 \\
0.133 \\
0.133 \\
6.133 \\
0.133 \\
0.133 \\
0.133 \\
0.133 \\
0.133 \\
0.133 \\
0.133 \\
0.133 \\
0.133\end{array}$ & 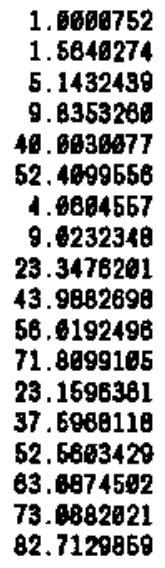 \\
\hline TEST & $\begin{array}{l}\text { ICP IDA } \\
\text { (Leach) }\end{array}$ & $\begin{array}{l}\text { ICP LAB } \\
\text { (Leach) }\end{array}$ & $\begin{array}{l}\text { ICP LABY } \\
\text { (G) ass) }\end{array}$ & $\begin{array}{l}\mathbf{S A} / \boldsymbol{N} \\
(/ \mathbf{O})\end{array}$ & $\begin{array}{l}\text { UEACH ICP } \\
\text { DATA }\end{array}$ & $\begin{array}{l}\text { DILUTIOH } \\
\text { FACTOR }\end{array}$ & c & $\begin{array}{l}\text { Oxide ItS } \\
\text { (glass ICP) }\end{array}$ & $\mathbf{F}$ & $\begin{array}{c}\text { Norealized } \\
\text { Conc. Fo }\end{array}$ & $\begin{array}{l}\text { LEACH ICP } \\
\text { DATA }\end{array}$ & $\begin{array}{l}\text { DILUTION } \\
\text { FACTOR }\end{array}$ & c & $\begin{array}{l}\text { Oxide vtx } \\
\text { (glass ICP) }\end{array}$ & $\ddot{F}$ & $\begin{array}{c}\text { Mormalizod } \\
\text { Conc. Ug }\end{array}$ \\
\hline $\begin{array}{lll}231 & I & \hat{A} \\
231 & I & \hat{A} \\
231 & I & \hat{k} \\
231 & I & \hat{A} \\
231 & I & \hat{A} \\
231 & I & \hat{A} \\
231 & I & B \\
231 & I & B \\
231 & I & 8 \\
231 & I & 8 \\
231 & I & B \\
231 & I & 8 \\
231 & I & C \\
231 & I & C \\
231 & I & C \\
231 & I & C \\
231 & I & C \\
231 & I & C\end{array}$ & $\begin{array}{l}A 2 \\
A 9 \\
A 18 \\
A 23 \\
A 31 \\
A 37 \\
B 2 \\
B 9 \\
B 16 \\
B 23 \\
839 \\
837 \\
C 2 \\
C 9 \\
C 16 \\
C 23 \\
C 30 \\
C 37\end{array}$ & $\begin{array}{l}292 \\
292 \\
292 \\
292 \\
292 \\
292 \\
294 \\
204 \\
294 \\
294 \\
294 \\
294 \\
290 \\
290 \\
290 \\
290 \\
290 \\
290\end{array}$ & $\begin{array}{l}261 \\
261 \\
261 \\
201 \\
261 \\
261 \\
201 \\
201 \\
201 \\
201 \\
291 \\
201 \\
291 \\
291 \\
201 \\
201 \\
201 \\
201\end{array}$ & 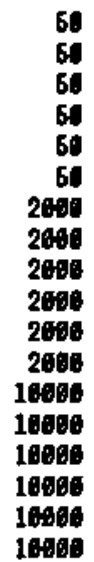 & 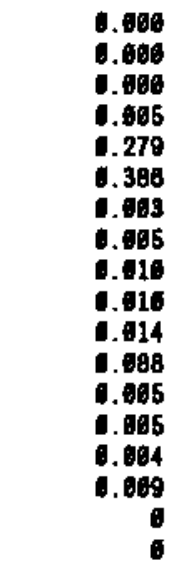 & $\begin{array}{r}1 \\
1 \\
1 \\
1 \\
1 \\
1 \\
5 \\
5 \\
5 \\
5 \\
5 \\
5 \\
10 \\
10 \\
10 \\
10 \\
10 \\
10\end{array}$ & 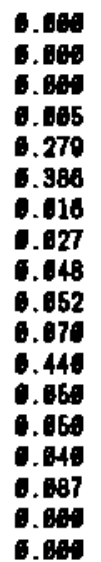 & $\begin{array}{l}4.41 \\
4.41 \\
4.41 \\
4.41 \\
4.41 \\
4.41 \\
4.41 \\
4.41 \\
4.41 \\
4.41 \\
4.41 \\
4.41 \\
4.41 \\
4.41 \\
4.41 \\
4.41 \\
4.41 \\
4.41\end{array}$ & 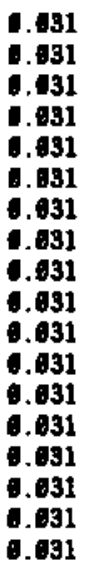 & 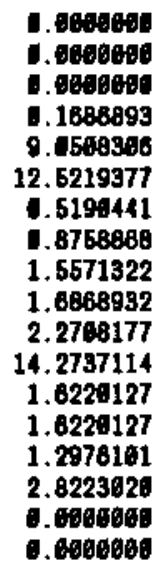 & 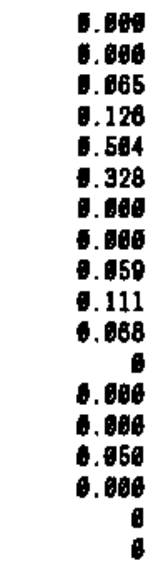 & $\begin{array}{r}1 \\
1 \\
1 \\
1 \\
1 \\
1 \\
5 \\
5 \\
5 \\
5 \\
5 \\
5 \\
10 \\
10 \\
10 \\
10 \\
10 \\
10\end{array}$ & 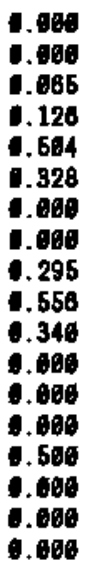 & $\begin{array}{l}2.15 \\
2.15 \\
2.15 \\
2.15 \\
2.15 \\
2.15 \\
2.15 \\
2.15 \\
2.15 \\
2.15 \\
2.15 \\
2.15 \\
2.15 \\
2.15 \\
2.15 \\
2.15 \\
2.15 \\
2.15\end{array}$ & $\begin{array}{r}0.013 \\
6.013 \\
6.013 \\
6.013 \\
6.013 \\
6.013 \\
6.013 \\
.013 \\
6.013 \\
6.013 \\
6.013 \\
6.013 \\
6.013 \\
6.013 \\
6.013 \\
6.013 \\
6.013 \\
6.013\end{array}$ & 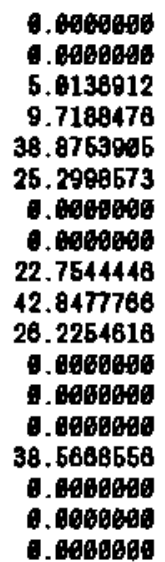 \\
\hline
\end{tabular}


CONTINED. WCE-WOD TEST RESULTS

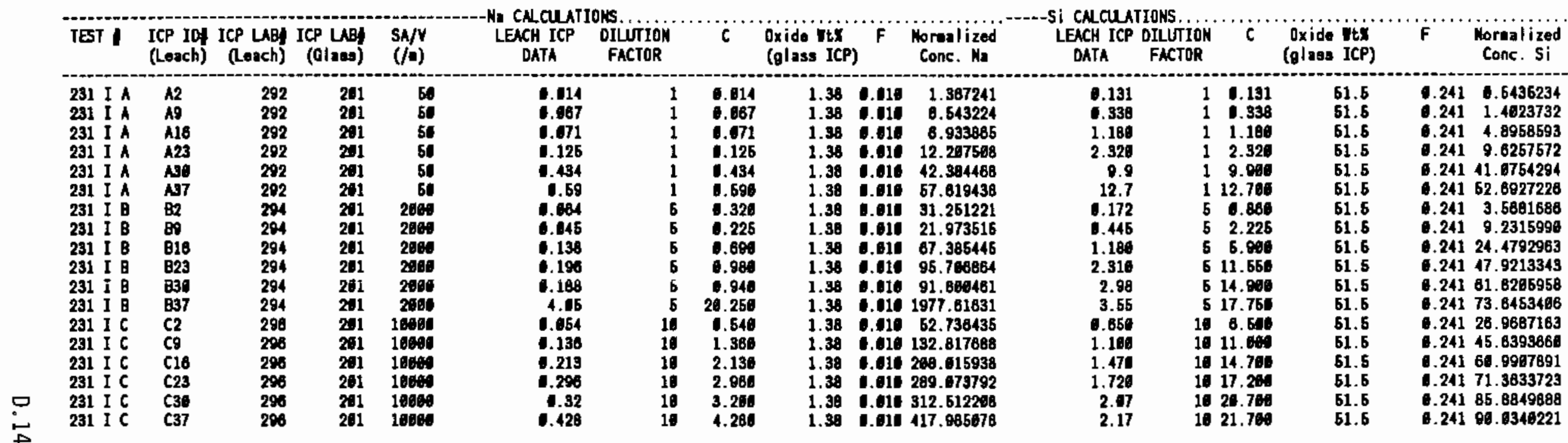

\begin{tabular}{|c|c|c|c|c|c|c|c|c|c|c|c|c|c|c|c|c|}
\hline TEST I & $\begin{array}{l}\text { ICP ID: } \\
\text { (Leach) }\end{array}$ & $\begin{array}{r}\text { ICP LAB' } \\
\text { (Lesch) }\end{array}$ & $\begin{array}{c}\text { ICP LAB } \\
\text { (Class) }\end{array}$ & $\begin{array}{l}S A / Y \\
(/ /)\end{array}$ & $\begin{array}{c}\text { LEACH ICP } \\
\text { DATA }\end{array}$ & $\begin{array}{l}\text { DILUTION } \\
\text { FACTOR }\end{array}$ & c & $\begin{array}{l}\text { Oxide ItK } \\
\text { (glass ICP) }\end{array}$ & $F$ & $\begin{array}{l}\text { Mormalizod } \\
\text { Conc. Sr }\end{array}$ & $\begin{array}{l}\text { LEACH ICP } \\
\text { DATA }\end{array}$ & $\begin{array}{l}\text { OILUTION } \\
\text { FACTOR }\end{array}$ & C & $\begin{array}{c}\text { Oxide ItX } \\
\text { (glaes ICP) }\end{array}$ & $F$ & $\begin{array}{l}\text { Norialized } \\
\text { Conc. Cs }\end{array}$ \\
\hline $\begin{array}{llll}231 & I & A \\
231 & I & A \\
231 & I & A \\
231 & I & A \\
231 & I & A \\
231 & I & A \\
231 & I & B \\
231 & I & B \\
231 & I & B \\
231 & I & B \\
231 & I & B \\
231 & I & B \\
231 & I & C \\
231 & I & C \\
231 & I & C \\
231 & I & C \\
231 & I & C \\
231 & I & C\end{array}$ & $\begin{array}{l}A 2 \\
A 9 \\
A 16 \\
A 23 \\
A 36 \\
A 37 \\
B 2 \\
B 9 \\
B 16 \\
B 23 \\
B 39 \\
837 \\
C 2 \\
C 9 \\
C 16 \\
C 23 \\
C 39 \\
C 37\end{array}$ & $\begin{array}{l}292 \\
292 \\
292 \\
292 \\
292 \\
292 \\
294 \\
294 \\
294 \\
294 \\
294 \\
294 \\
296 \\
298 \\
298 \\
296 \\
296 \\
298\end{array}$ & $\begin{array}{l}201 \\
201 \\
201 \\
201 \\
201 \\
201 \\
201 \\
201 \\
201 \\
201 \\
201 \\
201 \\
201 \\
201 \\
201 \\
291 \\
201 \\
201\end{array}$ & 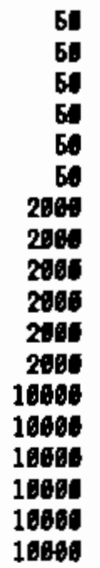 & 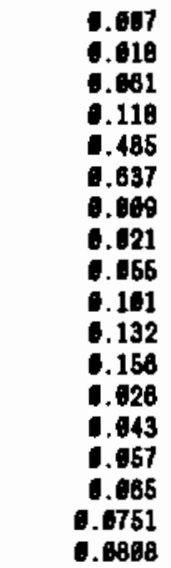 & $\begin{array}{r}1 \\
1 \\
1 \\
1 \\
1 \\
1 \\
5 \\
5 \\
5 \\
5 \\
5 \\
5 \\
10 \\
10 \\
10 \\
10 \\
10 \\
10\end{array}$ & $\begin{array}{r}0.0067 \\
0.6101 \\
0.0611 \\
0.1175 \\
0.485 \\
0.637 \\
0.643 \\
0.103 \\
0.273 \\
.505 \\
0.68 \\
0.78 \\
0.28 \\
0.43 \\
0.57 \\
0.65 \\
6.751 \\
0.808\end{array}$ & $\begin{array}{l}1.40 \\
1.4 \\
1.4 \\
1.40 \\
1.40 \\
1.4 \\
1.40 \\
1.40 \\
1.40 \\
1.40 \\
1.40 \\
1.40 \\
1.40 \\
1.40 \\
1.40 \\
1.4 \\
1.40 \\
1.4\end{array}$ & $\begin{array}{l}.0118 \\
.0118 \\
.0118 \\
.0118 \\
.0118 \\
.0118 \\
0118 \\
.0118 \\
.118 \\
0118 \\
0118 \\
.0118 \\
.0118 \\
.0118 \\
.0118 \\
.0118 \\
.0118 \\
.0118\end{array}$ & 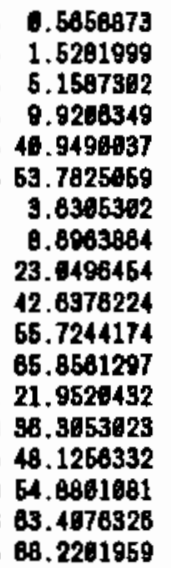 & 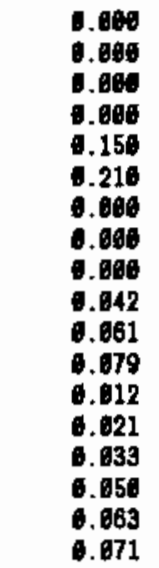 & $\begin{array}{r}1 \\
1 \\
1 \\
1 \\
1 \\
1 \\
5 \\
5 \\
5 \\
5 \\
5 \\
5 \\
10 \\
10 \\
10 \\
18 \\
10 \\
10\end{array}$ & $\begin{array}{r}0 \\
0 \\
0.15 \\
0.21 \\
0 \\
0 \\
6.21 \\
0.395 \\
0.395 \\
0.12 \\
0.21 \\
0.23 \\
0.6 \\
6.89 \\
0.71\end{array}$ & $\begin{array}{l}6.34 \\
6.34 \\
6.34 \\
6.34 \\
6.34 \\
.34 \\
.34 \\
.34 \\
.34 \\
6.34 \\
.34 \\
.34 \\
.34 \\
.34 \\
6.34 \\
6.34 \\
.34 \\
0.34\end{array}$ & $\begin{array}{l}6.603 \\
6.603 \\
6.063 \\
6.003 \\
6.003 \\
6.003 \\
6.003 \\
6.003 \\
6.003 \\
6.603 \\
6.003 \\
6.003 \\
6.003 \\
6.603 \\
0.003 \\
0.003 \\
0.003 \\
0.003\end{array}$ & 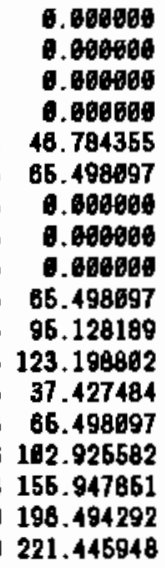 \\
\hline
\end{tabular}


CONTINUED. MCC-MOO TEST RESULSS

\begin{tabular}{|c|c|c|c|c|c|c|c|c|c|c|c|c|c|c|c|c|}
\hline TEST & $\begin{array}{l}\text { ICP IO } \\
\text { (Loach) }\end{array}$ & $\begin{array}{r}\text { ICP LAB } \\
\text { (Leach) }\end{array}$ & $\begin{array}{l}\text { ICP LABI } \\
\text { (Olass) }\end{array}$ & $\begin{array}{l}S N / V \\
(/ m)\end{array}$ & $\begin{array}{l}\text { LEACH ICP } \\
\text { DATA }\end{array}$ & $\begin{array}{l}\text { DILUTION } \\
\text { FACTOR }\end{array}$ & C & $\begin{array}{l}\text { Oxide VEX } \\
\text { (g|ass ICP) }\end{array}$ & $F$ & $\begin{array}{l}\text { Normalized } \\
\text { Conc. Al }\end{array}$ & $\begin{array}{c}\text { LEACH ICP } \\
\text { DATA }\end{array}$ & $\begin{array}{l}\text { DILUTION } \\
\text { FACTDR }\end{array}$ & $c$ & $\begin{array}{l}\text { Oxide Vts } \\
\text { (olass ICP) }\end{array}$ & $F$ & $\begin{array}{l}\text { Mormal ized } \\
\text { Conc. Ca }\end{array}$ \\
\hline 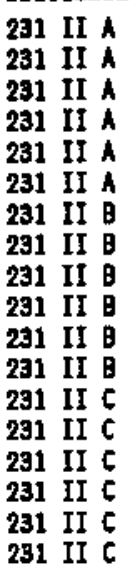 & $\begin{array}{l}A \\
A 10 \\
A 17 \\
A 24 \\
A 91 \\
A 38 \\
B 9 \\
B 10 \\
B 17 \\
B 24 \\
891 \\
838 \\
C 9 \\
\text { C10 } \\
\text { C17 } \\
C 24 \\
\text { C91 } \\
\text { Ca8 }\end{array}$ & $\begin{array}{l}292 \\
292 \\
292 \\
292 \\
292 \\
292 \\
294 \\
294 \\
294 \\
294 \\
294 \\
294 \\
296 \\
296 \\
296 \\
298 \\
298 \\
298\end{array}$ & $\begin{array}{l}201 \\
201 \\
201 \\
201 \\
201 \\
201 \\
201 \\
201 \\
201 \\
201 \\
201 \\
201 \\
201 \\
201 \\
201 \\
201 \\
201 \\
201\end{array}$ & 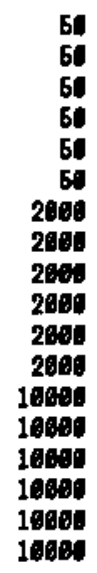 & 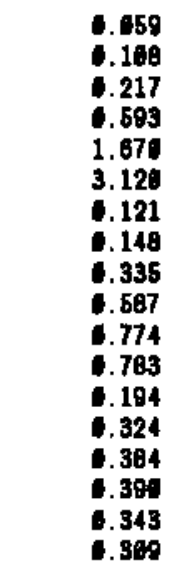 & $\begin{array}{r}1 \\
1 \\
1 \\
1 \\
1 \\
1 \\
5 \\
6 \\
5 \\
5 \\
5 \\
5 \\
16 \\
16 \\
16 \\
16 \\
16 \\
10\end{array}$ & 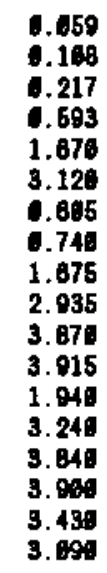 & $\begin{array}{l}13.1 \\
13.1 \\
13.1 \\
13.1 \\
13.1 \\
13.1 \\
13.1 \\
13.1 \\
13.1 \\
13.1 \\
13.1 \\
13.1 \\
13.1 \\
13.1 \\
13.1 \\
13.1 \\
13.1 \\
13.1\end{array}$ & 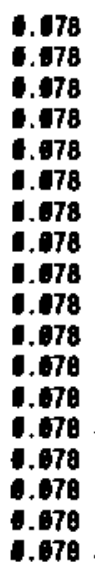 & 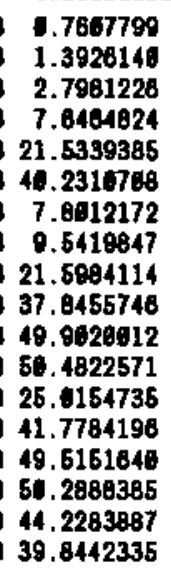 & $\begin{array}{r}0.682 \\
0.160 \\
0.376 \\
1.129 \\
3.16 \\
6.39 \\
6.128 \\
6.246 \\
6.628 \\
1.119 \\
1.49 \\
1.86 \\
0.291 \\
0.547 \\
1.713 \\
1.942 \\
0.998 \\
1.09\end{array}$ & $\begin{array}{r}1 \\
1 \\
1 \\
1 \\
1 \\
1 \\
5 \\
5 \\
5 \\
5 \\
5 \\
5 \\
10 \\
10 \\
10 \\
10 \\
10 \\
10\end{array}$ & $\begin{array}{l}0.082 \\
6.160 \\
6.370 \\
1.120 \\
3.150 \\
6.390 \\
1.830 \\
1.230 \\
3.106 \\
5.550 \\
7.456 \\
9.398 \\
2.910 \\
5.470 \\
7.130 \\
8.420 \\
9.980 \\
16.900\end{array}$ & 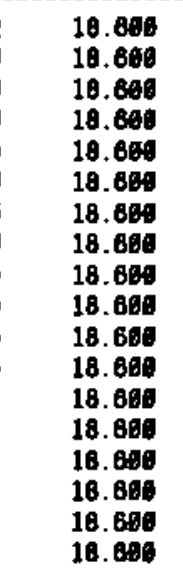 & $\begin{array}{l}0.133 \\
6.133 \\
6.139 \\
6.133 \\
6.133 \\
.133 \\
.133 \\
6.133 \\
6.133 \\
.133 \\
1.133 \\
.133 \\
.133 \\
.133 \\
1.133 \\
1.133 \\
.133 \\
1.133\end{array}$ & $\begin{array}{r}4.6165877 \\
1.2639989 \\
2.7821641 \\
8.4216858 \\
23.6859914 \\
48.6487256 \\
4.7371983 \\
9.2488157 \\
23.3160233 \\
41.7324611 \\
56.0192498 \\
69.9360699 \\
21.8813445 \\
41.1989121 \\
53.8139538 \\
79.8323934 \\
75.8432363 \\
81.9618497\end{array}$ \\
\hline TEST । & $\begin{array}{l}\text { ICP ID } \\
\text { (Loach) }\end{array}$ & $\begin{array}{l}\text { ICP LABY } \\
\text { (Leach) }\end{array}$ & $\begin{array}{l}\text { ICP LAB } \\
\text { (Class) }\end{array}$ & $\begin{array}{l}S N / V \\
(/ n)\end{array}$ & $\begin{array}{c}\text { LEACH ICP } \\
\text { DATA }\end{array}$ & $\begin{array}{l}\text { DILUTION } \\
\text { FACTOR }\end{array}$ & C & $\begin{array}{l}\text { Oxide VtX } \\
\text { (glass ICP) }\end{array}$ & $\mathbf{F}$ & $\begin{array}{l}\text { Hormalized } \\
\text { Cone. Fe }\end{array}$ & $\begin{array}{l}\text { LEACH ICP } \\
\text { DATA }\end{array}$ & $\begin{array}{l}\text { DILUTION } \\
\text { FACTOR }\end{array}$ & $c$ & $\begin{array}{l}\text { Oxide vt: } \\
\text { (glass ICP) }\end{array}$ & $F$ & $\begin{array}{l}\text { Normal ized } \\
\text { Conc. Ig }\end{array}$ \\
\hline 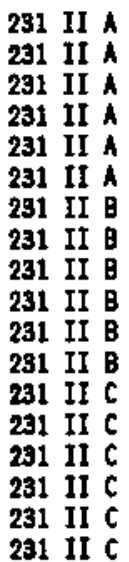 & $\begin{array}{l}A 3 \\
A 16 \\
A 17 \\
A 24 \\
A 31 \\
A 38 \\
B 3 \\
811 \\
B 17 \\
B 24 \\
B 31 \\
B 38 \\
C 3 \\
C 16 \\
C 17 \\
C 24 \\
C 31 \\
C 38\end{array}$ & $\begin{array}{l}292 \\
292 \\
292 \\
292 \\
292 \\
292 \\
294 \\
294 \\
294 \\
294 \\
294 \\
294 \\
296 \\
296 \\
296 \\
296 \\
296 \\
296\end{array}$ & $\begin{array}{l}201 \\
201 \\
201 \\
201 \\
201 \\
201 \\
201 \\
201 \\
201 \\
201 \\
201 \\
201 \\
201 \\
201 \\
201 \\
201 \\
201 \\
201\end{array}$ & 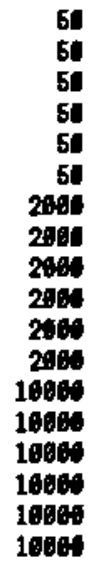 & 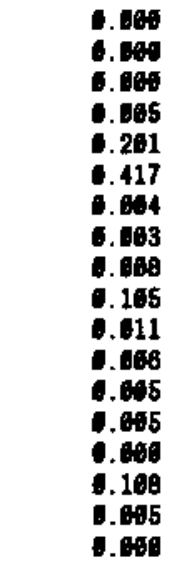 & $\begin{array}{r}1 \\
1 \\
1 \\
1 \\
1 \\
1 \\
5 \\
5 \\
5 \\
5 \\
5 \\
5 \\
10 \\
10 \\
10 \\
10 \\
10 \\
10\end{array}$ & $\begin{array}{r}0 \\
0 \\
0.0646 \\
6.261 \\
6.417 \\
0.62 \\
0.0125 \\
0.0465 \\
0.525 \\
6.655 \\
6.63 \\
0.649 \\
1.049 \\
0 \\
1.68 \\
0.66 \\
0\end{array}$ & $\begin{array}{l}4.410 \\
4.410 \\
4.410 \\
4.410 \\
4.410 \\
4.410 \\
4.410 \\
4.410 \\
4.410 \\
4.410 \\
4.410 \\
4.410 \\
4.410 \\
4.410 \\
4.410 \\
4.410 \\
4.410 \\
4.410\end{array}$ & $\begin{array}{l}0.091 \\
6.031 \\
6.031 \\
6.031 \\
0.031 \\
6.031 \\
6.031 \\
6.031 \\
6.031 \\
6.031 \\
6.031 \\
6.031 \\
6.031 \\
6.031 \\
6.031 \\
6.031 \\
6.031 \\
6.091\end{array}$ & 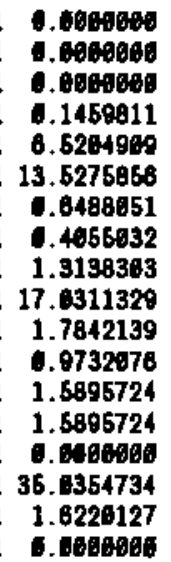 & 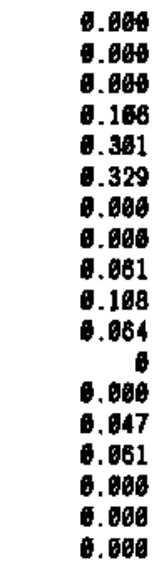 & $\begin{array}{c}1 \\
1 \\
1 \\
1 \\
1 \\
1 \\
5 \\
5 \\
5 \\
5 \\
5 \\
5 \\
10 \\
10 \\
10 \\
10 \\
10 \\
10\end{array}$ & $\begin{array}{r}0 \\
6.168 \\
6.361 \\
6.329 \\
0 \\
6.365 \\
0.54 \\
6.32 \\
0 \\
0.47 \\
6.61 \\
0 \\
0\end{array}$ & $\begin{array}{l}2.158 \\
2.158 \\
2.158 \\
2.158 \\
2.158 \\
2.158 \\
2.158 \\
2.158 \\
2.158 \\
2.158 \\
2.158 \\
2.158 \\
2.158 \\
2.150 \\
2.158 \\
2.158 \\
2.158 \\
2.158\end{array}$ & $\begin{array}{r}0.013 \\
0.013 \\
0.013 \\
.013 \\
0.013 \\
.013 \\
0.013 \\
0.013 \\
6.013 \\
6.613 \\
6.013 \\
6.013 \\
6.013 \\
6.013 \\
6.013 \\
6.613 \\
6.013 \\
6.013\end{array}$ & 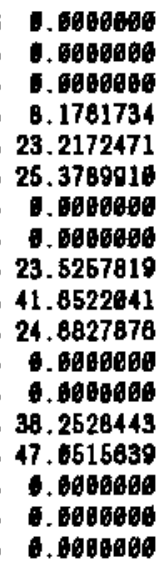 \\
\hline
\end{tabular}


CONTIMED. MCC-MDD TEST RESUTS

\begin{tabular}{|c|c|c|c|c|c|c|c|c|c|c|c|c|c|c|c|c|}
\hline TEST & $\begin{array}{l}\text { ICP IOA } \\
\text { (Loach) }\end{array}$ & $\begin{array}{l}\text { ICP LAB } \\
\text { (Leach) }\end{array}$ & $\begin{array}{l}\text { ICP LAQ } \\
\text { (Glass) }\end{array}$ & $\begin{array}{l}S N / Y \\
(/ L)\end{array}$ & $\begin{array}{l}\text { LEACH ICP } \\
\text { DATA }\end{array}$ & $\begin{array}{l}\text { DILUTION } \\
\text { FACTOR }\end{array}$ & C & $\begin{array}{l}\text { Oxide ItK } \\
\text { (glass ICP) }\end{array}$ & $F$ & $\begin{array}{l}\text { Normalized } \\
\text { Cone. Na }\end{array}$ & $\begin{array}{c}\text { LEACH ICP } \\
\text { DATA }\end{array}$ & $\begin{array}{l}\text { OILUTION } \\
\text { FACTOR }\end{array}$ & C & $\begin{array}{l}\text { Dxide Itx } \\
\text { (giass ICP) }\end{array}$ & $\mathbf{F}$ & $\begin{array}{l}\text { Nornalized } \\
\text { Conc. Si }\end{array}$ \\
\hline 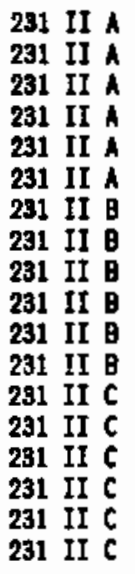 & $\begin{array}{l}A 3 \\
A 11 \\
A 17 \\
124 \\
A 31 \\
A 38 \\
83 \\
816 \\
817 \\
824 \\
831 \\
89 B \\
C 3 \\
C 10 \\
C 17 \\
C 24 \\
C 31 \\
C 39\end{array}$ & $\begin{array}{l}292 \\
292 \\
292 \\
292 \\
292 \\
292 \\
294 \\
294 \\
294 \\
294 \\
294 \\
294 \\
296 \\
290 \\
290 \\
298 \\
298 \\
298\end{array}$ & $\begin{array}{l}201 \\
201 \\
201 \\
201 \\
201 \\
201 \\
201 \\
201 \\
201 \\
201 \\
201 \\
201 \\
201 \\
201 \\
201 \\
201 \\
201 \\
201\end{array}$ & 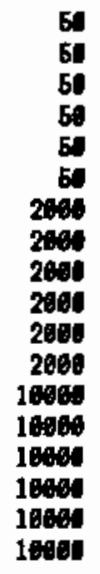 & 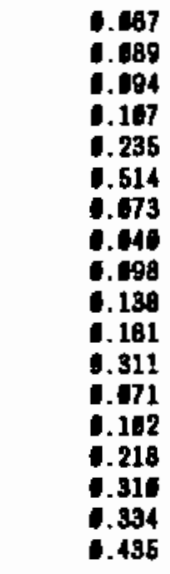 & $\begin{array}{r}1 \\
1 \\
1 \\
1 \\
1 \\
1 \\
5 \\
5 \\
5 \\
5 \\
5 \\
5 \\
10 \\
10 \\
10 \\
10 \\
10 \\
10\end{array}$ & $\begin{array}{r}0.087 \\
6.089 \\
0.694 \\
0.167 \\
0.235 \\
6.514 \\
6.365 \\
0.2 \\
6.49 \\
6.60 \\
6.885 \\
1.555 \\
. .71 \\
1.02 \\
2.18 \\
3.1 \\
3.34 \\
4.35\end{array}$ & $\begin{array}{l}1.384 \\
1.389 \\
1.384 \\
1.380 \\
1.380 \\
1.386 \\
1.386 \\
1.384 \\
1.384 \\
1.389 \\
1.380 \\
1.384 \\
1.380 \\
1.380 \\
1.386 \\
1.396 \\
1.386 \\
1.384\end{array}$ & 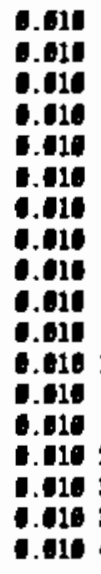 & $\begin{array}{r}6.543224 \\
8.691746 \\
9.188046 \\
10.449627 \\
22.069115 \\
56.197273 \\
35.846924 \\
18.532013 \\
47.859432 \\
67.395445 \\
69.382359 \\
151.891481 \\
69.398646 \\
99.613286 \\
212.698941 \\
982.746291 \\
326.184617 \\
424.821282\end{array}$ & $\begin{array}{r}0.128 \\
0.259 \\
0.593 \\
1.998 \\
5.8 \\
11.5 \\
0.187 \\
0.439 \\
1.179 \\
2.179 \\
2.98 \\
3.49 \\
0.613 \\
1.180 \\
1.509 \\
1.790 \\
2.699 \\
2.180\end{array}$ & $\begin{array}{r}1 \\
1 \\
1 \\
1 \\
1 \\
1 \\
5 \\
5 \\
5 \\
5 \\
5 \\
5 \\
10 \\
10 \\
10 \\
10 \\
10 \\
10\end{array}$ & $\begin{array}{r}0.128 \\
0.259 \\
6.593 \\
1.99 \\
5.8 \\
11.6 \\
1.935 \\
2.19 \\
5.85 \\
16.85 \\
14.9 \\
17.45 \\
6.19 \\
11.8 \\
15 \\
17.9 \\
28.9 \\
21.8\end{array}$ & $\begin{array}{l}51.5 \\
51.5 \\
51.5 \\
51.5 \\
51.5 \\
51.5 \\
51.5 \\
51.5 \\
51.5 \\
51.5 \\
51.5 \\
51.5 \\
51.5 \\
51.5 \\
51.5 \\
51.5 \\
51.5 \\
51.5\end{array}$ & $\begin{array}{l}6.241 \\
6.241 \\
.241 \\
0.241 \\
.241 \\
.241 \\
.241 \\
.241 \\
.241 \\
.241 \\
.241 \\
0.241 \\
. .241 \\
. .241 \\
.241 \\
.241 \\
.241 \\
. .241\end{array}$ & $\begin{array}{r}8.5316783 \\
1.0745998 \\
2.4683767 \\
8.2565762 \\
24.0643930 \\
47.7138827 \\
3.8793461 \\
9.6883829 \\
24.2718447 \\
45.8176110 \\
61.8295958 \\
72.4066397 \\
25.4335740 \\
48.9585926 \\
62.2354991 \\
74.2676956 \\
68.7147955 \\
89.8191187\end{array}$ \\
\hline
\end{tabular}

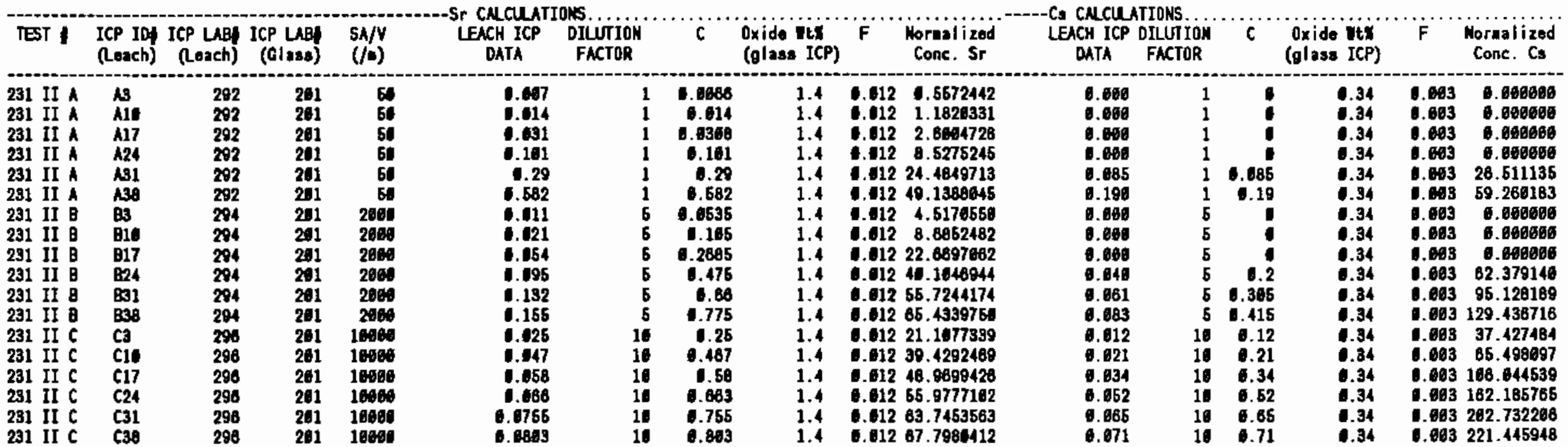




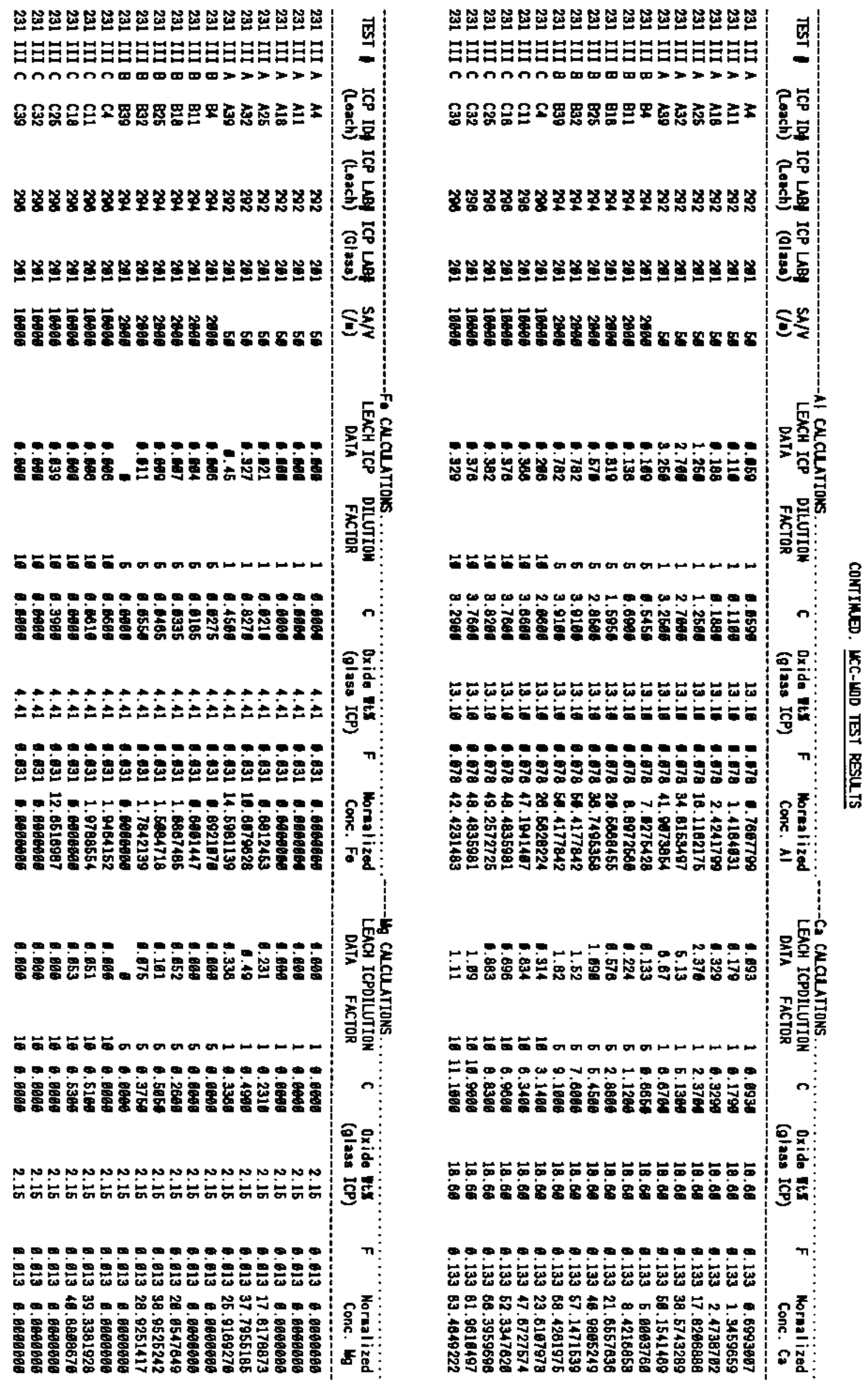


CONTINED. WCC-MDO TEST RESUTS

\begin{tabular}{|c|c|c|c|c|c|c|c|c|c|c|c|c|c|c|c|c|}
\hline TEST & $\begin{array}{l}\text { ICP ID } \\
\text { (Deach) }\end{array}$ & $\begin{array}{l}\text { ICP LAB } \\
\text { (Leach) }\end{array}$ & $\begin{array}{l}\text { ICP LAB } \\
\text { (Glaso) }\end{array}$ & $\begin{array}{l}S A / Y \\
(/ m)\end{array}$ & $\begin{array}{l}\text { LEACH ICP } \\
\text { DATA }\end{array}$ & FILUTIOA & $\dddot{c}$ & $\begin{array}{l}\text { oxide itx } \\
\text { (glass ICP) }\end{array}$ & $\dddot{F}$ & $\begin{array}{c}\text { Pormalized } \\
\text { Conc. Ha }\end{array}$ & $\begin{array}{l}\text { LEACH ICPD } \\
\text { DATA }\end{array}$ & $\begin{array}{l}\text { DILUTION } \\
\text { FACTOR }\end{array}$ & $\ddot{c}$ & $\begin{array}{l}\text { Dxide itx } \\
\text { (gless }\end{array}$ & $\dddot{F}$ & $\begin{array}{c}\text { Norwalized } \\
\text { Cone. Si }\end{array}$ \\
\hline 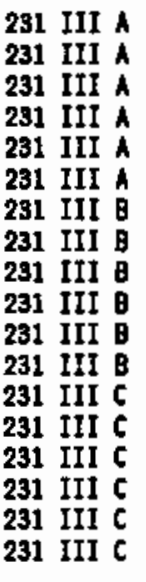 & $\begin{array}{l}M \\
A 11 \\
A 18 \\
A 18 \\
A 32 \\
A 39 \\
A 8 \\
B 1 \\
B 11 \\
818 \\
826 \\
832 \\
839 \\
C 4 \\
C 11 \\
C 18 \\
C 25 \\
C 32 \\
C 39\end{array}$ & $\begin{array}{l}292 \\
292 \\
292 \\
292 \\
292 \\
292 \\
299 \\
294 \\
294 \\
294 \\
294 \\
294 \\
298 \\
290 \\
296 \\
296 \\
298 \\
296\end{array}$ & $\begin{array}{l}291 \\
201 \\
2011 \\
2201 \\
201 \\
201 \\
2201 \\
201 \\
201 \\
201 \\
201 \\
201 \\
201 \\
291 \\
291 \\
291 \\
201 \\
201\end{array}$ & 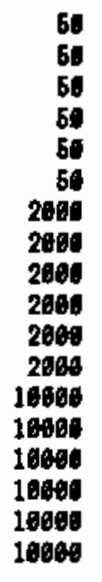 & 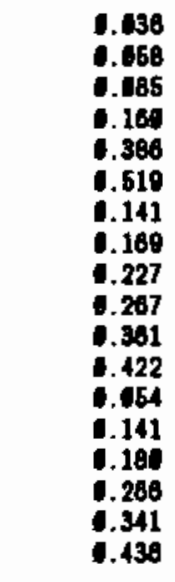 & $\begin{array}{r}1 \\
1 \\
1 \\
1 \\
1 \\
1 \\
5 \\
5 \\
5 \\
5 \\
5 \\
5 \\
10 \\
10 \\
10 \\
10 \\
10 \\
10\end{array}$ & 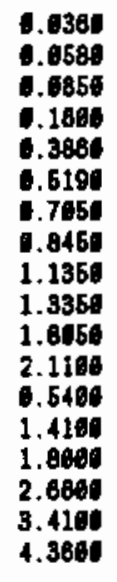 & $\begin{array}{l}1.38 \\
1.38 \\
1.38 \\
1.38 \\
1.38 \\
1.38 \\
1.38 \\
1.39 \\
1.38 \\
1.38 \\
1.38 \\
1.38 \\
1.38 \\
1.38 \\
1.38 \\
1.39 \\
1.39 \\
1.38\end{array}$ & 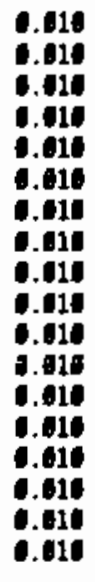 & 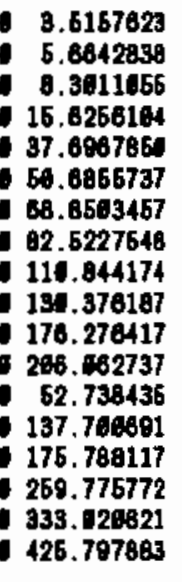 & 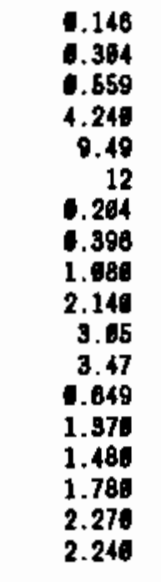 & $\begin{array}{cc}1 & \\
1 & \\
1 & \\
1 & \\
1 & \\
1 & 1 \\
5 & \\
5 & \\
5 & \\
5 & 1 \\
5 & 1 \\
5 & 1 \\
10 & \\
10 & 1 \\
10 & 1 \\
10 & 1 \\
10 & 2 \\
10 & 2\end{array}$ & 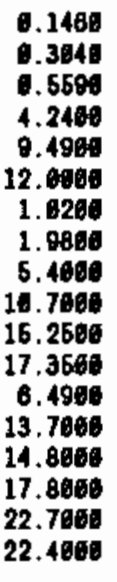 & $\begin{array}{l}51.50 \\
51.50 \\
51.58 \\
51.58 \\
51.56 \\
51.58 \\
51.56 \\
51.58 \\
51.58 \\
51.50 \\
51.68 \\
51.56 \\
51.68 \\
51.58 \\
51.58 \\
51.58 \\
51.50 \\
51.58\end{array}$ & 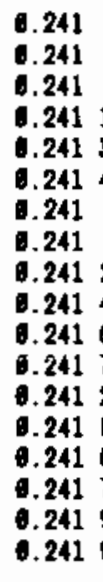 & 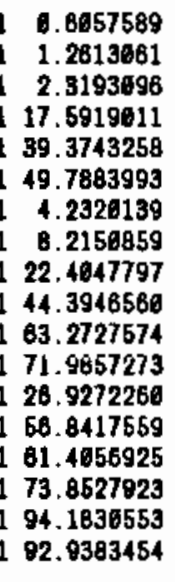 \\
\hline TEST & $\begin{array}{l}\text { ICP IDI } \\
\text { (Leach) }\end{array}$ & $\begin{array}{l}\text { ICP LAP } \\
\text { (Leach) }\end{array}$ & $\begin{array}{l}\text { ICP UBA } \\
\text { (G/ass) }\end{array}$ & $\begin{array}{l}\text { SN/N } \\
(/ N)\end{array}$ & LEACH ICP & $\begin{array}{l}\text { DILUTION } \\
\text { FACTOR }\end{array}$ & $\dddot{c}$ & $\begin{array}{l}\text { Oxide It: } \\
\text { (glass ICP) }\end{array}$ & $\mathbf{F}$ & $\begin{array}{l}\text { Moraslized } \\
\text { Canc. Sr }\end{array}$ & $\begin{array}{l}\text { LEACH ICPD } \\
\text { DATA }\end{array}$ & $\begin{array}{l}\text { DILUTION } \\
\text { FACTOR }\end{array}$ & $c$ & $\begin{array}{l}\text { Oxide Itx } \\
\text { (glass } \\
\text { (CP) }\end{array}$ & $\mathbf{F}$ & $\begin{array}{c}\text { Moranlized } \\
\text { Cone. Cs }\end{array}$ \\
\hline 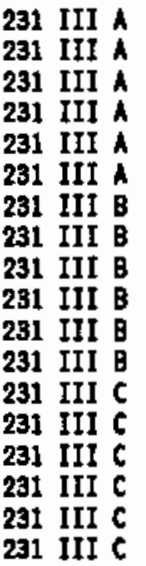 & $\begin{array}{l}M \\
A 11 \\
A 18 \\
A 25 \\
A 92 \\
A 39 \\
B 4 \\
811 \\
818 \\
818 \\
B 25 \\
832 \\
B 39 \\
C 4 \\
C 11 \\
C 18 \\
C 25 \\
C 32 \\
C 39\end{array}$ & $\begin{array}{l}292 \\
292 \\
292 \\
292 \\
292 \\
292 \\
294 \\
294 \\
294 \\
294 \\
294 \\
294 \\
296 \\
296 \\
296 \\
299 \\
296 \\
296\end{array}$ & $\begin{array}{l}201 \\
201 \\
201 \\
201 \\
201 \\
201 \\
291 \\
201 \\
201 \\
291 \\
201 \\
201 \\
201 \\
201 \\
261 \\
201 \\
201 \\
201\end{array}$ & 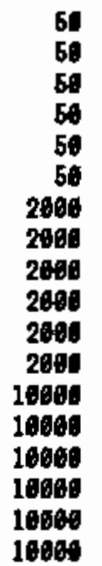 & 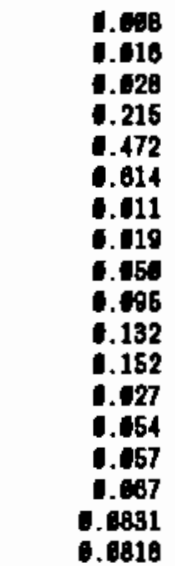 & $\begin{array}{r}1 \\
1 \\
1 \\
1 \\
1 \\
1 \\
5 \\
5 \\
5 \\
5 \\
5 \\
5 \\
16 \\
16 \\
16 \\
16 \\
16 \\
10\end{array}$ & 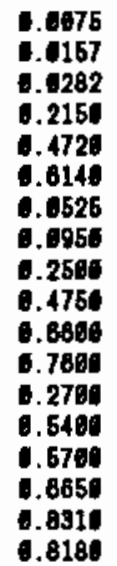 & $\begin{array}{l}1.40 \\
1.40 \\
1.40 \\
1.40 \\
1.40 \\
1.40 \\
1.40 \\
1.40 \\
1.40 \\
1.46 \\
1.40 \\
1.40 \\
1.40 \\
1.40 \\
1.40 \\
1.49 \\
1.40 \\
1.40\end{array}$ & 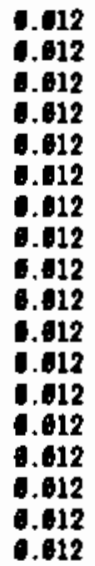 & 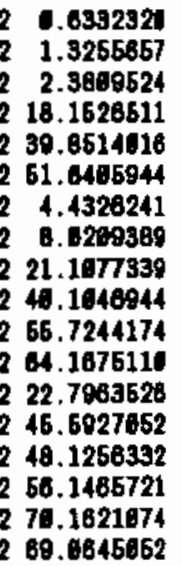 & 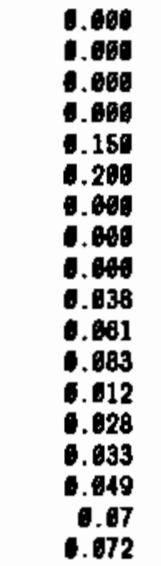 & $\begin{array}{r}1 \\
1 \\
1 \\
1 \\
1 \\
1 \\
5 \\
5 \\
5 \\
5 \\
5 \\
5 \\
10 \\
10 \\
10 \\
10 \\
10 \\
10\end{array}$ & 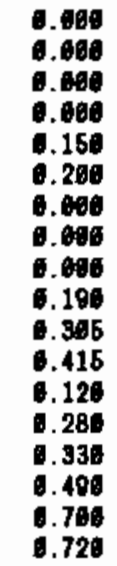 & $\begin{array}{l}6.34 \\
: .34 \\
6.34 \\
0.34 \\
0.34 \\
0.34 \\
1.34 \\
0.34 \\
0.34 \\
0.34 \\
0.34 \\
0.34 \\
0.34 \\
0.34 \\
0.34 \\
0.34 \\
0.34 \\
0.34\end{array}$ & 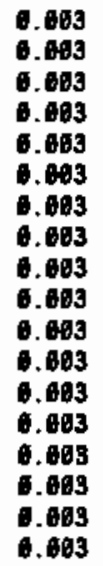 & 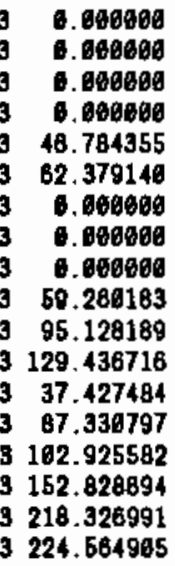 \\
\hline
\end{tabular}


CONTINED. WCC-HOD TEST RESULTS

\begin{tabular}{|c|c|c|c|c|c|c|c|c|c|c|c|c|c|c|c|c|}
\hline TEST & $\begin{array}{l}\text { ICP ID } \\
\text { (Leach) }\end{array}$ & ICP LAB: & $\begin{array}{l}\text { ICP LAB } \\
\text { (Olass) }\end{array}$ & $\begin{array}{l}\text { SH/V } \\
(1 / 0)\end{array}$ & $\begin{array}{c}\text { LEACH ICP } \\
\text { DATA }\end{array}$ & $\begin{array}{l}\text { DILUTION } \\
\text { FACTOR }\end{array}$ & $c$ & $\begin{array}{l}\text { Oxide it: } \\
\text { (glass ICP) }\end{array}$ & $F$ & $\begin{array}{l}\text { Mormalized } \\
\text { Conc. Al }\end{array}$ & $\begin{array}{c}\text { LEACH ICP } \\
\text { OATA }\end{array}$ & $\begin{array}{l}\text { DILUTION } \\
\text { FACTOR }\end{array}$ & $c$ & $\begin{array}{l}\text { Oxido Utx } \\
\text { (glass ICP) }\end{array}$ & $\mathbf{F}$ & $\begin{array}{l}\text { Normalized } \\
\text { Cone. Ca }\end{array}$ \\
\hline 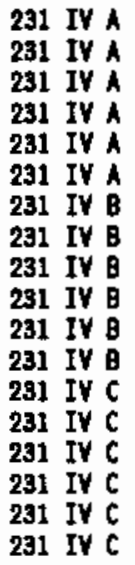 & $\begin{array}{l}A b \\
A 12 \\
A 19 \\
A 28 \\
A 93 \\
A 41 \\
B 5 \\
812 \\
B 19 \\
B 28 \\
B 33 \\
B 41 \\
C 5 \\
C 12 \\
C 18 \\
C 26 \\
C 33 \\
C 46\end{array}$ & $\begin{array}{l}292 \\
292 \\
202 \\
202 \\
292 \\
292 \\
294 \\
294 \\
294 \\
294 \\
294 \\
294 \\
296 \\
298 \\
296 \\
298 \\
296 \\
298\end{array}$ & $\begin{array}{l}201 \\
201 \\
201 \\
201 \\
201 \\
201 \\
201 \\
201 \\
201 \\
211 \\
201 \\
201 \\
201 \\
201 \\
201 \\
201 \\
201 \\
201\end{array}$ & 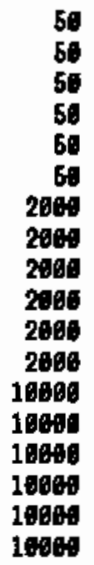 & 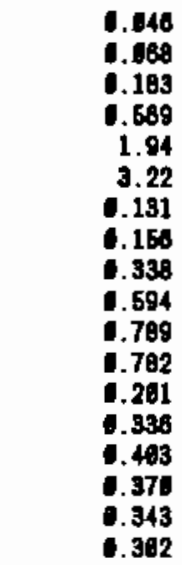 & $\begin{array}{r}1 \\
1 \\
1 \\
1 \\
1 \\
1 \\
6 \\
5 \\
5 \\
5 \\
5 \\
5 \\
19 \\
10 \\
10 \\
10 \\
10 \\
10\end{array}$ & $\begin{array}{l}1.046 \\
0.668 \\
1.183 \\
0.669 \\
1.949 \\
3.220 \\
1.655 \\
1.780 \\
1.698 \\
2.976 \\
3.045 \\
3.019 \\
2.010 \\
3.360 \\
4.030 \\
3.790 \\
3.430 \\
3.026\end{array}$ & $\begin{array}{l}13.10 \\
13.10 \\
13.10 \\
13.10 \\
13.10 \\
13.10 \\
13.10 \\
13.10 \\
13.10 \\
13.10 \\
13.10 \\
13.10 \\
13.10 \\
13.10 \\
13.10 \\
13.10 \\
13.10 \\
13.10\end{array}$ & $\begin{array}{l}0.078 \\
.078 \\
.078 \\
0.078 \\
0.078 \\
6.078 \\
6.078 \\
.078 \\
6.078 \\
6.078 \\
6.078 \\
.078 \\
6.078 \\
6.078 \\
6.078 \\
0.078 \\
6.078 \\
6.878\end{array}$ & $\begin{array}{r}6.6031664 \\
.8768310 \\
2.3697670 \\
7.3370126 \\
25.0164735 \\
41.5265282 \\
6.4459469 \\
16.6577877 \\
21.7918986 \\
38.2968847 \\
64.8699943 \\
50.4177842 \\
25.9189937 \\
43.3257885 \\
51.9851391 \\
47.7699237 \\
44.2283887 \\
38.9416134\end{array}$ & 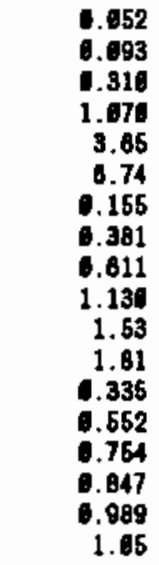 & $\begin{array}{r}1 \\
1 \\
1 \\
1 \\
1 \\
1 \\
5 \\
5 \\
5 \\
5 \\
5 \\
5 \\
10 \\
10 \\
10 \\
10 \\
10 \\
10\end{array}$ & $\begin{array}{r}0.052 \\
6.693 \\
6.319 \\
1.070 \\
3.850 \\
6.746 \\
.775 \\
1.805 \\
3.655 \\
5.650 \\
7.650 \\
9.650 \\
3.350 \\
5.520 \\
7.540 \\
8.470 \\
9.889 \\
1 . .509\end{array}$ & $\begin{array}{l}18.60 \\
18.60 \\
18.80 \\
18.66 \\
18.86 \\
18.69 \\
18.69 \\
18.69 \\
18.60 \\
18.80 \\
18.60 \\
18.68 \\
18.60 \\
18.60 \\
18.60 \\
18.68 \\
18.69 \\
18.60\end{array}$ & $\begin{array}{l}1.193 \\
6.133 \\
0.133 \\
0.133 \\
.133 \\
.133 \\
6.133 \\
0.193 \\
0.193 \\
6.139 \\
6.133 \\
6.133 \\
6.133 \\
6.133 \\
6.133 \\
6.133 \\
0.193 \\
6.133\end{array}$ & 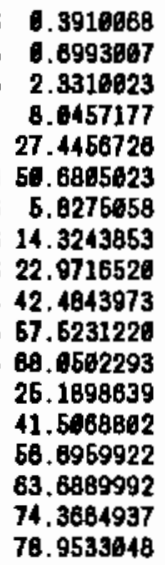 \\
\hline
\end{tabular}

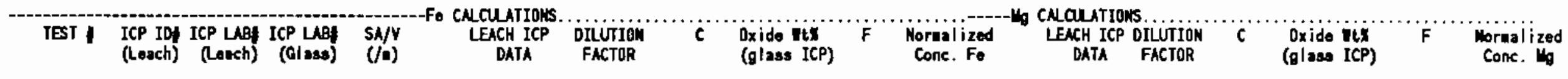

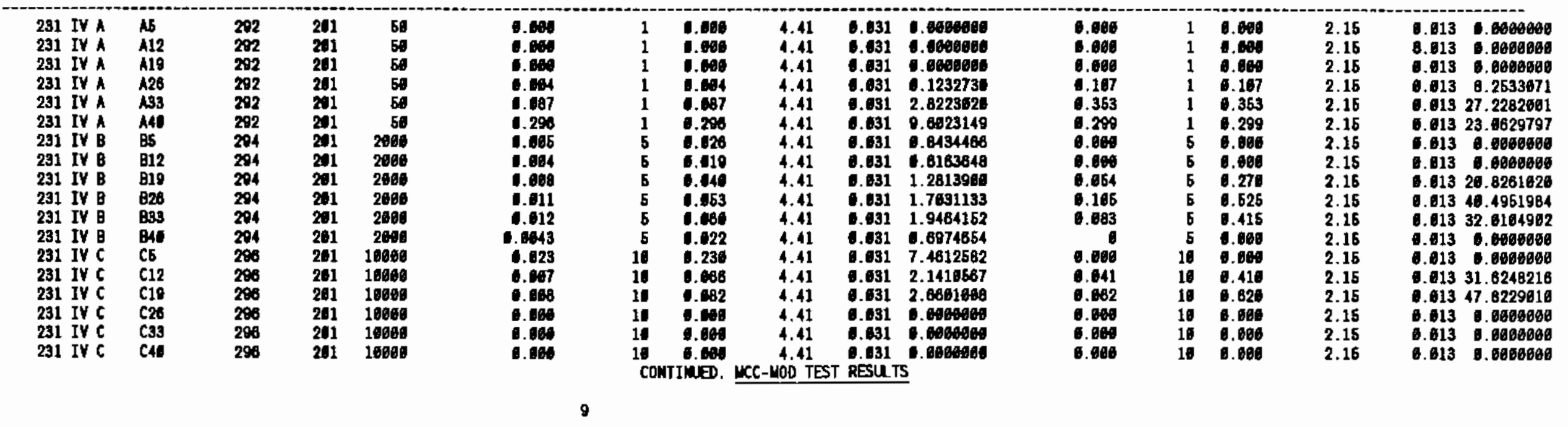




\begin{tabular}{|c|c|c|c|c|c|c|c|c|c|c|c|c|c|c|c|c|}
\hline TEST & $\begin{array}{l}\text { ICP ID } \\
\text { (Loach) }\end{array}$ & $\begin{array}{r}\text { ICP LAB } \\
\text { (Leach) }\end{array}$ & $\begin{array}{r}\text { ICP LAB } \\
\text { (Glaso) }\end{array}$ & $\begin{array}{l}S A / N \\
(/ n)\end{array}$ & $\begin{array}{c}\text { LEACH ICP } \\
\text { DATA }\end{array}$ & $\begin{array}{l}\text { DILUTION } \\
\text { FACTOR }\end{array}$ & c & $\begin{array}{l}\text { Dxide VtI } \\
\text { (glass ICP) }\end{array}$ & $\mathbf{F}$ & $\begin{array}{l}\text { Moraal ized } \\
\text { Conc. Ma }\end{array}$ & $\begin{array}{c}\text { LEACH ICP } \\
\text { DATA }\end{array}$ & $\begin{array}{l}\text { DILUTION } \\
\text { FACTOR }\end{array}$ & c & $\begin{array}{l}\text { Oxide Dts } \\
\text { (glass ICP) }\end{array}$ & $\mathrm{F}$ & $\begin{array}{l}\text { Mormalized } \\
\text { Conc. Si }\end{array}$ \\
\hline $\begin{array}{l}231 \text { IV } \hat{A} \\
231 \text { IV } \hat{A} \\
231 \text { IV } \hat{A} \\
231 \text { IV } \hat{A} \\
231 \text { IV } \hat{A} \\
231 \text { IV } \hat{A} \\
231 \text { IV } \\
231 \text { IV } \\
231 \text { IV } \\
231 \text { IV } \\
231 \text { IV } \\
231 \text { IV } \\
231 \text { IV } C \\
231 \text { IV } C \\
231 \text { IV } C \\
231 \text { IV } \bar{c} \\
231 \text { IV } C \\
231 \text { IV } C\end{array}$ & $\begin{array}{l}A 5 \\
A 12 \\
A 19 \\
A 26 \\
A 33 \\
A 41 \\
85 \\
B 12 \\
819 \\
826 \\
B 93 \\
B 46 \\
C 5 \\
C 12 \\
C 19 \\
C 28 \\
C 33 \\
C 46\end{array}$ & $\begin{array}{l}292 \\
292 \\
292 \\
292 \\
292 \\
292 \\
294 \\
294 \\
294 \\
294 \\
294 \\
294 \\
296 \\
290 \\
200 \\
200 \\
290 \\
200\end{array}$ & $\begin{array}{l}201 \\
201 \\
201 \\
201 \\
201 \\
201 \\
201 \\
201 \\
201 \\
201 \\
211 \\
201 \\
201 \\
291 \\
201 \\
201 \\
291 \\
201\end{array}$ & 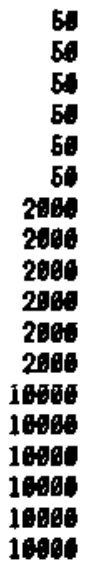 & 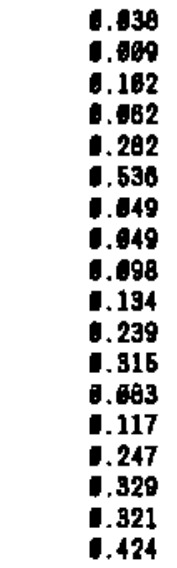 & $\begin{array}{r}1 \\
1 \\
1 \\
1 \\
1 \\
1 \\
5 \\
5 \\
5 \\
5 \\
5 \\
5 \\
10 \\
10 \\
10 \\
10 \\
10 \\
10\end{array}$ & 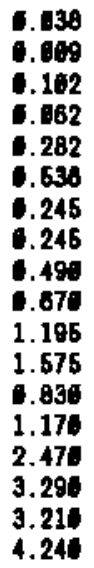 & 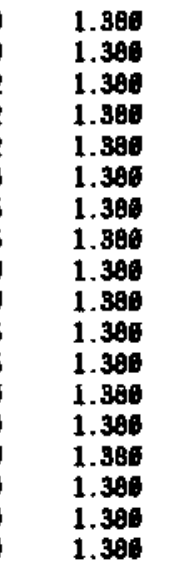 & 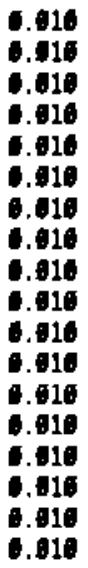 & $\begin{array}{r}3.516762 \\
6.876941 \\
9.981327 \\
8.854924 \\
27.546138 \\
52.945796 \\
23.926716 \\
23.928716 \\
47.853132 \\
65.432243 \\
116.793777 \\
153.814862 \\
81.857864 \\
114.262276 \\
241.226386 \\
321.991813 \\
313.488868 \\
414.978676\end{array}$ & $\begin{array}{r}0.077 \\
.150 \\
9.530 \\
1.980 \\
6.8 \\
12 \\
1.252 \\
0.471 \\
1.150 \\
2.190 \\
3.08 \\
3.44 \\
1.638 \\
1.296 \\
1.810 \\
1.784 \\
2.699 \\
2.109\end{array}$ & $\begin{array}{r}1 \\
1 \\
1 \\
1 \\
1 \\
1 \\
5 \\
5 \\
5 \\
5 \\
5 \\
5 \\
10 \\
10 \\
10 \\
10 \\
10 \\
10\end{array}$ & 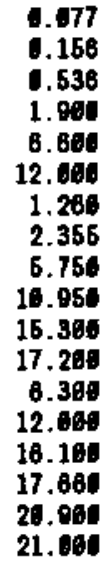 & $\begin{array}{l}51.50 \\
51.50 \\
51.50 \\
61.50 \\
51.50 \\
51.50 \\
51.50 \\
51.50 \\
51.50 \\
51.50 \\
51.50 \\
51.50 \\
61.50 \\
51.50 \\
51.50 \\
51.50 \\
51.50 \\
51.50\end{array}$ & $\begin{array}{l}0.241 \\
.241 \\
0.241 \\
0.241 \\
0.241 \\
.241 \\
.241 \\
.241 \\
.241 \\
.241 \\
.241 \\
0.241 \\
0.241 \\
0.241 \\
.241 \\
.241 \\
0.241 \\
.241\end{array}$ & $\begin{array}{r}.3287263 \\
.8472492 \\
2.2238816 \\
7.8831632 \\
26.2134283 \\
49.7883993 \\
5.2277819 \\
9.7709734 \\
23.8589413 \\
46.4319144 \\
63.4862691 \\
71.3833723 \\
26.1389698 \\
49.7883993 \\
66.7994357 \\
73.6229868 \\
88.7147955 \\
87.1298988\end{array}$ \\
\hline
\end{tabular}

\begin{tabular}{|c|c|c|c|c|c|c|c|c|c|c|c|c|c|c|c|c|}
\hline TEST & $\begin{array}{l}\text { ICP ID } \\
\text { (Leach) }\end{array}$ & $\begin{array}{r}\text { ICP LAB } \\
\text { (Leach) }\end{array}$ & $\begin{array}{l}\text { ICP LAB } \\
\text { (Olass) }\end{array}$ & $\begin{array}{l}5 A / N \\
(/)\end{array}$ & $\begin{array}{l}\text { LEACH ICP } \\
\text { DATA }\end{array}$ & DILUTION & C & $\begin{array}{l}\text { Oxide ItI } \\
\text { (olass ICP) }\end{array}$ & $\mathbf{F}$ & $\begin{array}{l}\text { Morwalized } \\
\text { Conc. Sr }\end{array}$ & $\begin{array}{l}\text { LEACH ICP } \\
\text { DATA }\end{array}$ & $\begin{array}{l}\text { DILUTION } \\
\text { FACTOR }\end{array}$ & C & $\begin{array}{l}\text { Dxide itx } \\
\text { (glass ICP) }\end{array}$ & $F$ & $\begin{array}{l}\text { Normal ized } \\
\text { Conc. Co }\end{array}$ \\
\hline $\begin{array}{l}231 \text { IV } \\
231 \text { IV } \\
231 \text { IV } \\
231 \text { IV } \\
231 \text { IV } \\
231 \text { IV } \\
231 \text { IV } \\
231 \text { IV } \\
231 \text { IV } \\
231 \text { IV } \\
231 \text { IV } \\
231 \text { IV } \\
231 \text { IV } \\
231 \text { IV } \\
231 \text { IV } \\
231 \text { IV } \\
231 \text { IV } \\
231 \text { IV } \\
\text { C }\end{array}$ & $\begin{array}{l}A 5 \\
A 12 \\
A 10 \\
A 28 \\
A 33 \\
A 41 \\
B 5 \\
B 12 \\
B 19 \\
B 26 \\
B 33 \\
B 19 \\
C 5 \\
C 12 \\
C 19 \\
C 28 \\
C 33 \\
C 46\end{array}$ & $\begin{array}{l}\mathbf{2 9 2} \\
\mathbf{2 9 2} \\
292 \\
292 \\
292 \\
292 \\
294 \\
294 \\
294 \\
294 \\
294 \\
294 \\
296 \\
296 \\
298 \\
298 \\
298 \\
296\end{array}$ & $\begin{array}{l}201 \\
201 \\
201 \\
261 \\
201 \\
261 \\
261 \\
261 \\
261 \\
261 \\
201 \\
201 \\
201 \\
201 \\
201 \\
201 \\
211 \\
201\end{array}$ & 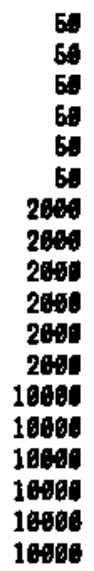 & 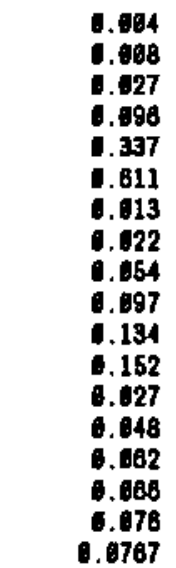 & $\begin{array}{r}1 \\
1 \\
1 \\
1 \\
1 \\
1 \\
5 \\
5 \\
5 \\
6 \\
5 \\
5 \\
10 \\
10 \\
10 \\
10 \\
10 \\
10\end{array}$ & 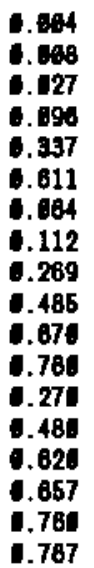 & $\begin{array}{l}1.40 \\
1.40 \\
1.40 \\
1.49 \\
1.49 \\
1.49 \\
1.40 \\
1.49 \\
1.40 \\
1.49 \\
1.40 \\
1.49 \\
1.49 \\
1.49 \\
1.40 \\
1.40 \\
1.49 \\
1.40\end{array}$ & 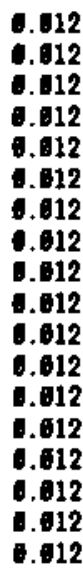 & 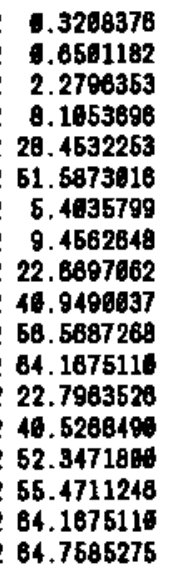 & 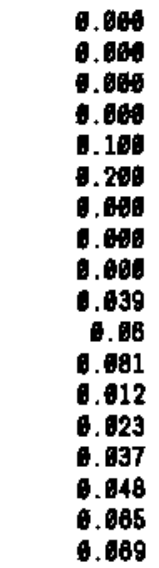 & $\begin{array}{r}1 \\
1 \\
1 \\
1 \\
1 \\
1 \\
1 \\
5 \\
5 \\
5 \\
5 \\
5 \\
5 \\
10 \\
10 \\
10 \\
10 \\
10 \\
10\end{array}$ & 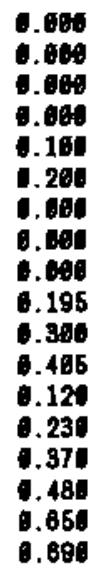 & $\begin{array}{l}0.34 \\
0.34 \\
6.34 \\
6.34 \\
6.34 \\
0.34 \\
0.34 \\
0.34 \\
0.34 \\
6.34 \\
6.34 \\
6.34 \\
0.34 \\
0.34 \\
0.34 \\
6.34 \\
0.34 \\
0.34\end{array}$ & 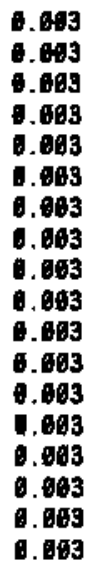 & 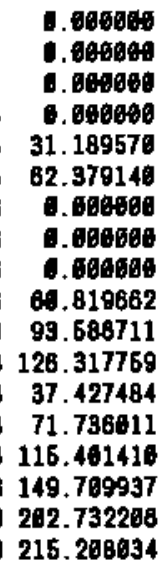 \\
\hline
\end{tabular}


CONTIHUED. LCC-MDD TEST RESULTS

\begin{tabular}{|c|c|c|c|c|c|c|c|c|c|c|c|c|c|c|c|c|}
\hline TEST & $\begin{array}{l}\text { CP ID } \\
\text { (Leach) }\end{array}$ & $\begin{array}{l}\text { ICP LAP } \\
\text { (Leach) }\end{array}$ & $\begin{array}{l}\text { ICP LAB } \\
\text { (Olass) }\end{array}$ & $\begin{array}{l}\text { SA/N } \\
(/ \mathbf{L})\end{array}$ & $\begin{array}{l}\text { LEACH ICP } \\
\text { DATA }\end{array}$ & $\begin{array}{l}\text { DILUTION } \\
\text { FACTOR }\end{array}$ & c & $\begin{array}{l}\text { Dxide its } \\
\text { (glass ICP) }\end{array}$ & $F$ & $\begin{array}{l}\text { Moraal ized } \\
\text { Conc. Al }\end{array}$ & $\begin{array}{c}\text { LELCH ICP } \\
\text { DATA }\end{array}$ & $\begin{array}{l}\text { DIUTION } \\
\text { FACTOR }\end{array}$ & c & $\begin{array}{l}\text { oxide ity } \\
\text { (glass ICP) }\end{array}$ & $\mathbf{F}$ & $\begin{array}{c}\text { Nornal ized } \\
\text { Conc. Ca }\end{array}$ \\
\hline $\begin{array}{ll}232 & \hat{A} \\
232 & \hat{A} \\
232 & \hat{A} \\
232 & \hat{A} \\
232 & \hat{A} \\
232 & \hat{A} \\
232 & \mathrm{~B} \\
232 & \mathrm{~B} \\
232 & \mathrm{~B} \\
232 & \mathrm{~B} \\
232 & \mathrm{~B} \\
232 & \mathrm{~B} \\
232 & \mathrm{C} \\
232 & \mathrm{C} \\
232 & \mathrm{C} \\
232 & \mathrm{C} \\
232 & \mathrm{C} \\
232 & \mathrm{C}\end{array}$ & $\begin{array}{c}A B \\
A 13 \\
A 20 \\
A 27 \\
A 34 \\
A 41 \\
B 8 \\
B 13 \\
B 29 \\
B 27 \\
B 34 \\
B 41 \\
C B \\
C 13 \\
C 26 \\
C 27 \\
C 34 \\
C 41\end{array}$ & $\begin{array}{l}292 \\
292 \\
292 \\
292 \\
292 \\
292 \\
294 \\
294 \\
294 \\
294 \\
294 \\
294 \\
296 \\
296 \\
298 \\
298 \\
290 \\
208\end{array}$ & $\begin{array}{l}202 \\
202 \\
202 \\
202 \\
202 \\
202 \\
202 \\
202 \\
202 \\
202 \\
202 \\
202 \\
202 \\
202 \\
202 \\
202 \\
202 \\
202\end{array}$ & 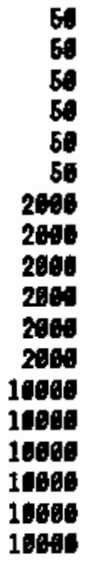 & $\begin{array}{r}0.064 \\
1.097 \\
0.174 \\
0.614 \\
2.35 \\
3.68 \\
0.122 \\
0.152 \\
0.392 \\
0.699 \\
0.784 \\
0.79 \\
0.224 \\
.332 \\
.392 \\
6.396 \\
0.352 \\
0.387\end{array}$ & $\begin{array}{r}1 \\
1 \\
1 \\
1 \\
1 \\
1 \\
5 \\
5 \\
5 \\
5 \\
5 \\
5 \\
10 \\
10 \\
10 \\
10 \\
10 \\
10\end{array}$ & $\begin{array}{r}0.684 \\
6.697 \\
.174 \\
.614 \\
2.35 \\
3.66 \\
1.61 \\
. .76 \\
1.66 \\
2.995 \\
3.02 \\
3.85 \\
2.24 \\
3.32 \\
3.92 \\
3.9 \\
3.52 \\
3.07\end{array}$ & $\begin{array}{l}13.2 \\
13.2 \\
13.2 \\
13.2 \\
13.2 \\
13.2 \\
13.2 \\
13.2 \\
13.2 \\
13.2 \\
13.2 \\
13.2 \\
13.2 \\
13.2 \\
13.2 \\
13.2 \\
13.2 \\
13.2\end{array}$ & $\begin{array}{r}6.078 \\
6.078 \\
6.078 \\
6.078 \\
6.078 \\
6.078 \\
6.079 \\
6.078 \\
6.078 \\
6.078 \\
6.078 \\
6.078 \\
6.078 \\
0.078 \\
0.078 \\
0.078 \\
6.078 \\
0.078\end{array}$ & 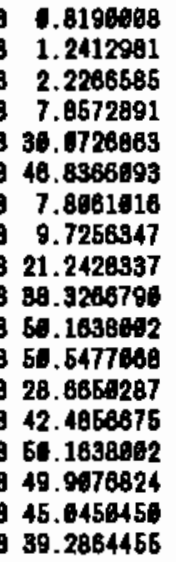 & $\begin{array}{r}1.690 \\
0.140 \\
0.279 \\
1.139 \\
4.47 \\
7.6 \\
0.334 \\
1.419 \\
0.696 \\
1.166 \\
1.52 \\
1.85 \\
6.343 \\
1.577 \\
0.745 \\
6.896 \\
0.977 \\
1.1\end{array}$ & $\begin{array}{r}1 \\
1 \\
1 \\
1 \\
1 \\
1 \\
5 \\
5 \\
6 \\
5 \\
5 \\
5 \\
10 \\
10 \\
10 \\
10 \\
10 \\
10\end{array}$ & $\begin{array}{r}0.60 \\
6.14 \\
1.279 \\
1.199 \\
4.47 \\
7.6 \\
1.689 \\
2.095 \\
3.84 \\
5.8 \\
7.6 \\
9.25 \\
3.49 \\
5.77 \\
7.45 \\
8.96 \\
9.77 \\
11\end{array}$ & 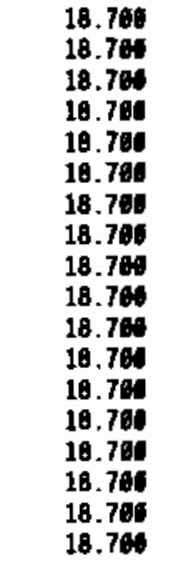 & $\begin{array}{l}0.134 \\
0.134 \\
0.134 \\
0.134 \\
0.134 \\
6.134 \\
6.134 \\
0.134 \\
0.134 \\
0.134 \\
0.134 \\
0.134 \\
6.134 \\
6.194 \\
6.134 \\
0.134 \\
0.134 \\
0.134\end{array}$ & 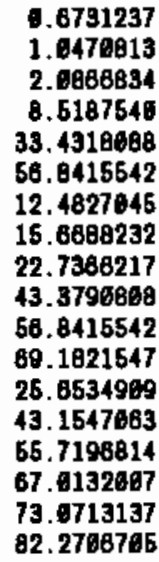 \\
\hline
\end{tabular}

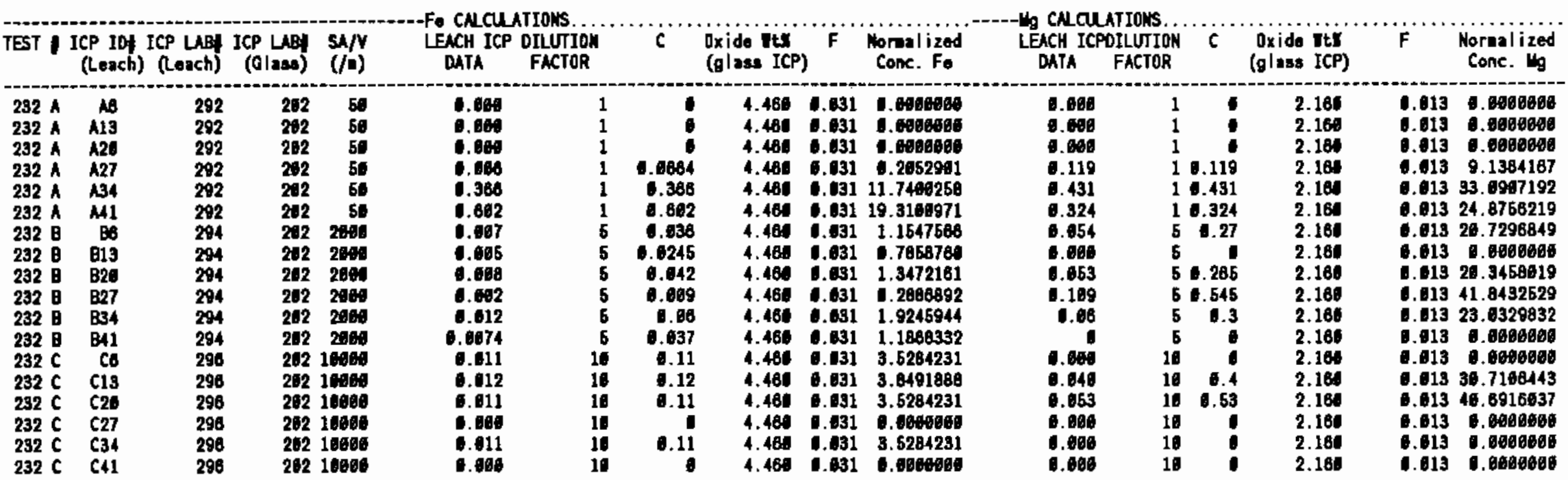


CONTIMED. WCC-WO TEST RESULTS

\begin{tabular}{|c|c|c|c|c|c|c|c|c|c|c|c|c|c|c|c|c|}
\hline TEST & $\begin{array}{l}\text { ICP ID } \\
\text { (Loach) }\end{array}$ & ICP LAB & $\begin{array}{c}\text { IOP LAB } \\
\text { (OInss) }\end{array}$ & $\begin{array}{l}\mathrm{SA} / \mathrm{N} \\
(/ \mathrm{a})\end{array}$ & $\begin{array}{l}\text { LEACH ICP } \\
\text { DATA }\end{array}$ & $\begin{array}{l}\text { DILUTION } \\
\text { FACTOR }\end{array}$ & c & $\begin{array}{l}\text { Oxjde tis } \\
\text { (glass ICP) }\end{array}$ & $\mathbf{F}$ & $\begin{array}{l}\text { Moras ized } \\
\text { Conc. Ha }\end{array}$ & $\begin{array}{l}\text { LEACH ICP } \\
\text { DATA }\end{array}$ & $\begin{array}{l}\text { POILUTIDN } \\
\text { FACTOR }\end{array}$ & $i$ & $\begin{array}{l}\text { oxido itx } \\
\text { (glass ICP) }\end{array}$ & $F$ & $\begin{array}{l}\text { Moraalized } \\
\text { Cone. } 5 i\end{array}$ \\
\hline $\begin{array}{ll}232 & A \\
232 & A \\
232 & \hat{A} \\
232 & \hat{A} \\
232 & \hat{A} \\
232 & \hat{A} \\
232 & \mathrm{~B} \\
232 & \mathrm{~B} \\
232 & \mathrm{~B} \\
232 & \mathrm{~B} \\
292 & \mathrm{~B} \\
232 & \mathrm{~B} \\
232 & \mathrm{C} \\
232 & \mathrm{C} \\
232 & \mathrm{C} \\
232 & \mathrm{C} \\
232 & \mathrm{C} \\
232 & \mathrm{C}\end{array}$ & $\begin{array}{c}16 \\
A 13 \\
A 21 \\
A 27 \\
A 34 \\
A 11 \\
60 \\
813 \\
820 \\
827 \\
B 34 \\
B 41 \\
C 8 \\
C 13 \\
C 20 \\
C 27 \\
C 34 \\
C 41\end{array}$ & $\begin{array}{l}292 \\
292 \\
292 \\
292 \\
292 \\
292 \\
294 \\
294 \\
294 \\
294 \\
294 \\
294 \\
298 \\
296 \\
298 \\
298 \\
208 \\
208\end{array}$ & $\begin{array}{l}202 \\
202 \\
202 \\
202 \\
2012 \\
2012 \\
202 \\
202 \\
202 \\
202 \\
202 \\
202 \\
202 \\
202 \\
202 \\
202 \\
202 \\
202\end{array}$ & 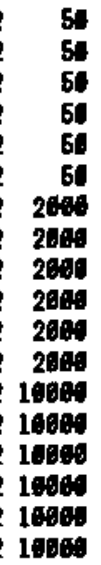 & 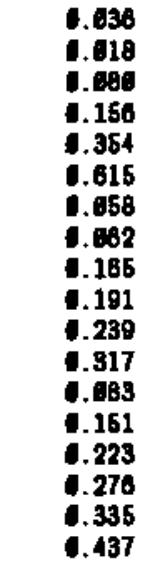 & $\begin{array}{r}1 \\
1 \\
1 \\
1 \\
1 \\
1 \\
5 \\
5 \\
5 \\
6 \\
5 \\
5 \\
10 \\
10 \\
10 \\
10 \\
10 \\
10\end{array}$ & 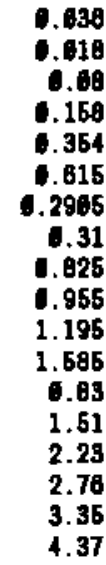 & $\begin{array}{l}1.470 \\
1.470 \\
1.470 \\
1.470 \\
1.470 \\
1.471 \\
1.470 \\
1.470 \\
1.470 \\
1.470 \\
1.470 \\
1.470 \\
1.470 \\
1.470 \\
1.470 \\
1.470 \\
1.470 \\
1.470\end{array}$ & $\begin{array}{r}0.011 \\
0.011 \\
0.011 \\
0.011 \\
. .011 \\
0.011 \\
0.011 \\
. .011 \\
0.011 \\
0.011 \\
. .011 \\
0.011 \\
0.011 \\
0.011 \\
0.011 \\
0.011 \\
.011 \\
0.011\end{array}$ & $\begin{array}{r}3.390512 \\
1.659256 \\
7.394476 \\
14.382217 \\
32.456931 \\
58.393739 \\
26.653295 \\
28.421072 \\
75.636724 \\
87.655238 \\
109.658648 \\
145.314196 \\
78.095128 \\
139.438125 \\
294.448356 \\
253.039221 \\
367.139939 \\
494.645433\end{array}$ & 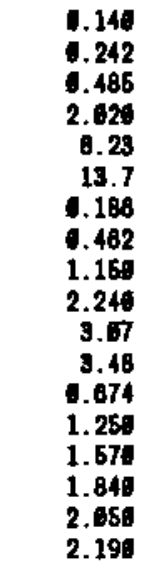 & $\begin{array}{r}1 \\
1 \\
1 \\
1 \\
1 \\
1 \\
5 \\
5 \\
5 \\
5 \\
5 \\
5 \\
10 \\
10 \\
10 \\
10 \\
10 \\
10\end{array}$ & 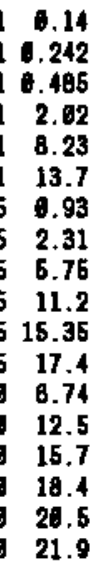 & $\begin{array}{l}\mathbf{5 2} \\
\mathbf{5 2} \\
\mathbf{5 2} \\
\mathbf{6 2} \\
\mathbf{5 2} \\
\mathbf{5 2} \\
\mathbf{5 2} \\
\mathbf{5 2} \\
\mathbf{5 2} \\
\mathbf{5 2} \\
\mathbf{5 2} \\
\mathbf{5 2} \\
\mathbf{5 2} \\
\mathbf{5 2} \\
\mathbf{5 2} \\
\mathbf{6 2} \\
\mathbf{5 2} \\
\mathbf{5 2}\end{array}$ & $\begin{array}{l}0.243 \\
0.243 \\
.243 \\
0.243 \\
6.243 \\
0.243 \\
.243 \\
0.243 \\
0.243 \\
.243 \\
.243 \\
.243 \\
.243 \\
.243 \\
.243 \\
.249 \\
.243 \\
.243\end{array}$ & 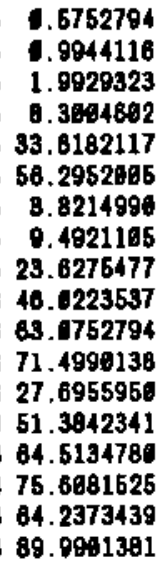 \\
\hline TEST & ICP IOA & $\begin{array}{l}\text { ICP LAB } \\
\text { (Leach) }\end{array}$ & $\begin{array}{l}\text { ICP LAB } \\
\text { (Glass) }\end{array}$ & $\begin{array}{l}\text { SA/Y } \\
(/ D)\end{array}$ & $\begin{array}{c}- \text {-5r CALCU } \\
\text { LEACH ICP } \\
\text { DATA }\end{array}$ & $\begin{array}{l}\text { ATIONS... } \\
\text { DILUTIOH } \\
\text { FACTER }\end{array}$ & $\ddot{c}$ & $\begin{array}{l}\text { Oxido Vt: } \\
\text { (glass ICP) }\end{array}$ & $F$ & $\begin{array}{l}\text { Mornal ized } \\
\text { Conc. Sr }\end{array}$ & $\begin{array}{c}\text { LECH ICP } \\
\text { DATA }\end{array}$ & $\begin{array}{l}\text { LATIONS, } \\
\text { POILUTION } \\
\text { FACTOR }\end{array}$ & $c$ & $\begin{array}{l}\text { oxido Tts } \\
\text { (glass ICP) }\end{array}$ & $\mathbf{F}$ & $\begin{array}{l}\text { Mormalized } \\
\text { Conc. Cs }\end{array}$ \\
\hline 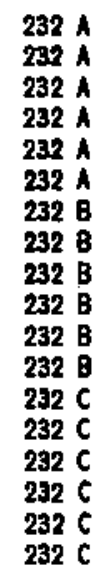 & $\begin{array}{l}16 \\
A 13 \\
A 21 \\
A 27 \\
A 34 \\
M 11 \\
B 8 \\
013 \\
B 21 \\
B 27 \\
B 34 \\
B 11 \\
C 6 \\
C 13 \\
C 26 \\
C 27 \\
C 34 \\
\text { C11 }\end{array}$ & $\begin{array}{l}292 \\
292 \\
292 \\
292 \\
292 \\
292 \\
204 \\
294 \\
294 \\
294 \\
294 \\
294 \\
298 \\
298 \\
298 \\
298 \\
290 \\
296\end{array}$ & $\begin{array}{l}202 \\
201 \\
202 \\
202 \\
201 \\
202 \\
202 \\
202 \\
262 \\
201 \\
202 \\
202 \\
2012 \\
262 \\
262 \\
202 \\
202 \\
202\end{array}$ & 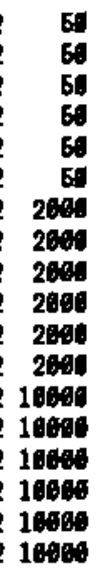 & 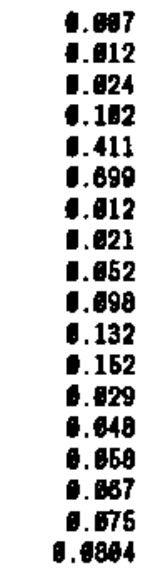 & $\begin{array}{r}1 \\
1 \\
1 \\
1 \\
1 \\
1 \\
5 \\
5 \\
5 \\
5 \\
5 \\
5 \\
10 \\
10 \\
10 \\
10 \\
18 \\
10\end{array}$ & 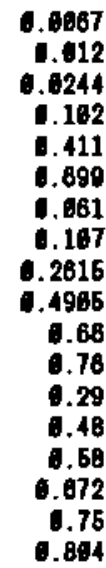 & $\begin{array}{l}1.4 \\
1.4 \\
1.4 \\
1.4 \\
1.4 \\
1.4 \\
1.4 \\
1.4 \\
1.4 \\
1.4 \\
1.4 \\
1.4 \\
1.4 \\
1.4 \\
1.4 \\
1.4 \\
1.4 \\
1.4\end{array}$ & 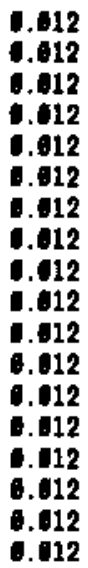 & 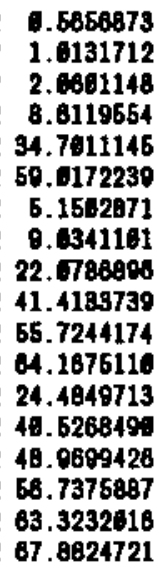 & 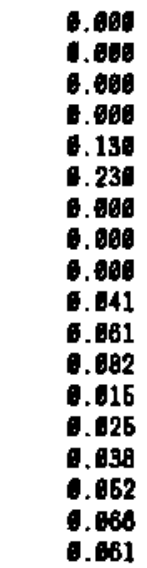 & $\begin{array}{r}1 \\
1 \\
1 \\
1 \\
1 \\
1 \\
5 \\
5 \\
5 \\
5 \\
5 \\
5 \\
10 \\
10 \\
10 \\
10 \\
10 \\
10\end{array}$ & $\begin{array}{rr}1 & 0 \\
1 & 0 \\
1 & 0 \\
1 & 0.13 \\
1 & .23 \\
5 & 0 \\
5 & 0 \\
5 & 0 \\
5 & .285 \\
5 & 0.385 \\
5 & 0.41 \\
0.16 \\
.25 \\
0.38 \\
0.62 \\
0.88 \\
0.81\end{array}$ & $\begin{array}{l}0.34 \\
0.34 \\
0.34 \\
0.34 \\
6.34 \\
6.34 \\
0.34 \\
0.34 \\
0.34 \\
0.34 \\
0.34 \\
0.34 \\
0.34 \\
0.34 \\
0.34 \\
6.34 \\
0.34 \\
0.34\end{array}$ & 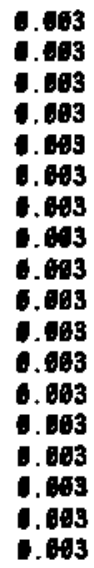 & 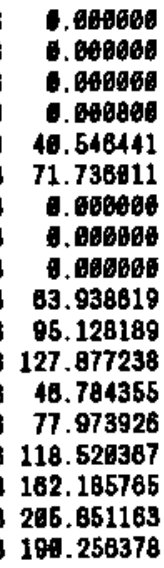 \\
\hline
\end{tabular}


CONTINUED. MEC-MOD TEST RESULTS

\begin{tabular}{|c|c|c|c|c|c|c|c|c|c|c|c|c|c|c|c|c|}
\hline TEST & $\begin{array}{l}\text { ICP ID } \\
\text { (Leach) }\end{array}$ & $\begin{array}{l}\text { ICP LAB } \\
\text { (Leach) }\end{array}$ & $\begin{array}{l}\text { ICP LAB } \\
\text { (Olass) }\end{array}$ & $\begin{array}{l}S A / V \\
(/ D)\end{array}$ & $\begin{array}{c}\text { LEACH ICP } \\
\text { DATA }\end{array}$ & $\begin{array}{l}\text { DILUTIBA } \\
\text { FACTOR }\end{array}$ & c & $\begin{array}{l}\text { Dxido it) } \\
\text { (glass ICP) }\end{array}$ & $F$ & $\begin{array}{l}\text { Moraalized } \\
\text { Conc. Al }\end{array}$ & $\begin{array}{c}\text { LEACH ICP } \\
\text { DATA }\end{array}$ & $\begin{array}{l}\text { DILUTIOKK } \\
\text { FACTOR }\end{array}$ & $c$ & $\begin{array}{l}\text { Oxide Tts } \\
\text { (glass ICP) }\end{array}$ & $F$ & $\begin{array}{c}\text { Mornalized } \\
\text { Conc. Ca }\end{array}$ \\
\hline $\begin{array}{ll}293 & \hat{A} \\
233 & \hat{A} \\
239 & \hat{A} \\
233 & \hat{A} \\
233 & \hat{A} \\
233 & \hat{A} \\
233 & \mathrm{~B} \\
293 & \mathrm{~B} \\
233 & \mathrm{~B} \\
233 & \mathrm{~B} \\
233 & \mathrm{~B} \\
233 & \mathrm{~B} \\
233 & \mathrm{C} \\
233 & \mathrm{C} \\
233 & \mathrm{C} \\
233 & \mathrm{C} \\
233 & \mathrm{C} \\
233 & \mathrm{C}\end{array}$ & $\begin{array}{l}A 7 \\
A 14 \\
A 21 \\
A 28 \\
A 35 \\
M 42 \\
B 7 \\
B 14 \\
821 \\
B 2 B \\
B 35 \\
842 \\
C 7 \\
C 14 \\
C 21 \\
C 28 \\
C 35 \\
C 42\end{array}$ & $\begin{array}{l}292 \\
292 \\
292 \\
292 \\
292 \\
292 \\
294 \\
294 \\
294 \\
294 \\
294 \\
294 \\
296 \\
296 \\
296 \\
296 \\
296 \\
298\end{array}$ & 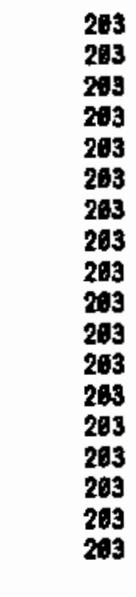 & 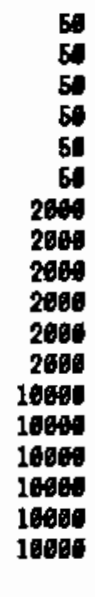 & 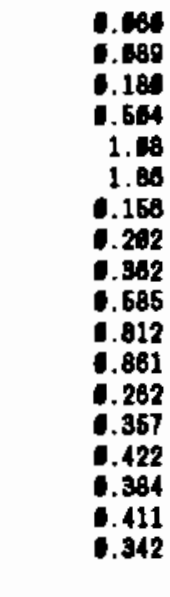 & $\begin{array}{l}1 \\
1 \\
1 \\
1 \\
1 \\
1 \\
5 \\
5 \\
5 \\
5 \\
5 \\
5 \\
16 \\
10 \\
10 \\
10 \\
10 \\
10\end{array}$ & $\begin{array}{l}0.680 \\
0.889 \\
6.180 \\
6.604 \\
1.080 \\
1.860 \\
0.780 \\
1.616 \\
1.810 \\
2.825 \\
4.968 \\
4.396 \\
2.620 \\
3.570 \\
4.228 \\
3.840 \\
4.110 \\
3.420\end{array}$ & $\begin{array}{l}13.2 \\
13.2 \\
13.2 \\
13.2 \\
13.2 \\
13.2 \\
13.2 \\
13.2 \\
13.2 \\
13.2 \\
13.2 \\
13.2 \\
13.2 \\
13.2 \\
13.2 \\
13.2 \\
13.2 \\
13.2\end{array}$ & 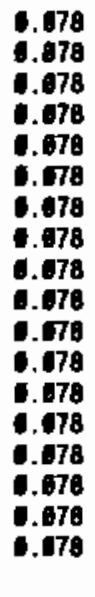 & 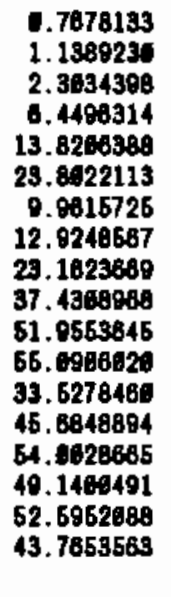 & $\begin{array}{r}0.147 \\
0.248 \\
6.616 \\
1.848 \\
2.8 \\
3.77 \\
0.411 \\
0.582 \\
6.758 \\
6.988 \\
1.69 \\
1.17 \\
1.783 \\
0.825 \\
0.946 \\
0.843 \\
8.994 \\
1.94\end{array}$ & $\begin{array}{r}1 \\
1 \\
1 \\
1 \\
1 \\
1 \\
5 \\
5 \\
5 \\
6 \\
5 \\
6 \\
10 \\
18 \\
10 \\
10 \\
10 \\
10\end{array}$ & $\begin{array}{r}1.147 \\
0.24 \\
0.615 \\
1.84 \\
2.8 \\
3.77 \\
2.055 \\
2.91 \\
3.75 \\
4.84 \\
6.45 \\
5.85 \\
7.83 \\
8.25 \\
9.46 \\
8.43 \\
9.84 \\
10.4\end{array}$ & $\begin{array}{l}18.7 \\
18.7 \\
16.7 \\
18.7 \\
18.7 \\
18.7 \\
18.7 \\
18.7 \\
16.7 \\
18.7 \\
18.7 \\
18.7 \\
18.7 \\
18.7 \\
18.7 \\
18.7 \\
18.7 \\
18.7\end{array}$ & $\begin{array}{l}0.134 \\
.134 \\
.134 \\
.134 \\
.134 \\
.134 \\
.134 \\
0.134 \\
.134 \\
.134 \\
.134 \\
.134 \\
0.134 \\
.134 \\
6.134 \\
.134 \\
0.134 \\
0.134\end{array}$ & $\begin{array}{r}1.0994353 \\
1.7949864 \\
4.5996784 \\
12.2658891 \\
26.9416252 \\
28.1964025 \\
15.3696571 \\
21.7643319 \\
28.0468195 \\
36.1998950 \\
46.7813777 \\
43.7638384 \\
57.0659287 \\
81.7638629 \\
76.7527766 \\
63.0492562 \\
74.9427695 \\
77.7831794\end{array}$ \\
\hline IEST & $\begin{array}{l}\text { ICP IOH } \\
\text { (Leach) }\end{array}$ & $\begin{array}{l}\text { ICP LABt } \\
\text { (Loach) }\end{array}$ & $\begin{array}{l}\text { ICP LAB } \\
\text { (Glass) }\end{array}$ & $\begin{array}{l}S A / N \\
(/ \sigma)\end{array}$ & $\begin{array}{l}\text { LEACH ICP } \\
\text { DATA }\end{array}$ & $\begin{array}{l}\text { DILUTION } \\
\text { FACTOR }\end{array}$ & c & $\begin{array}{l}\text { Oxido ItI } \\
\text { (glass ICP) }\end{array}$ & $\mathbf{F}$ & $\begin{array}{c}\text { Mornal ized } \\
\text { Conc. Fo }\end{array}$ & $\begin{array}{l}\text { LEACH ICP } \\
\text { DATA }\end{array}$ & $\begin{array}{l}\text { DILUTIÖ } \\
\text { FACTOR }\end{array}$ & $i$ & $\begin{array}{l}\text { Dxide itx } \\
\text { (glass ICP) }\end{array}$ & $\ddot{F}$ & $\begin{array}{l}\text { Mornalized } \\
\text { Conc. Hg }\end{array}$ \\
\hline 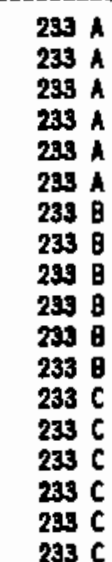 & $\begin{array}{l}A 7 \\
A 14 \\
A 21 \\
A 2 B \\
A 35 \\
M 42 \\
B 7 \\
B 14 \\
B 21 \\
B 28 \\
B 35 \\
B 42 \\
C 7 \\
C 14 \\
C 21 \\
C 28 \\
C 35 \\
C 42\end{array}$ & $\begin{array}{l}292 \\
292 \\
292 \\
292 \\
292 \\
292 \\
294 \\
294 \\
294 \\
294 \\
294 \\
294 \\
296 \\
296 \\
296 \\
296 \\
296 \\
296\end{array}$ & $\begin{array}{l}293 \\
293 \\
203 \\
269 \\
263 \\
263 \\
263 \\
263 \\
203 \\
203 \\
293 \\
203 \\
203 \\
263 \\
263 \\
293 \\
263 \\
293\end{array}$ & 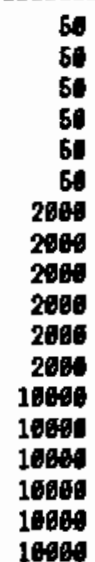 & 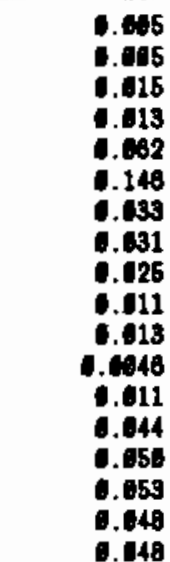 & $\begin{array}{r}1 \\
1 \\
1 \\
1 \\
1 \\
1 \\
5 \\
5 \\
5 \\
5 \\
5 \\
5 \\
16 \\
10 \\
10 \\
10 \\
10 \\
10\end{array}$ & $\begin{array}{r}0.095 \\
0.0048 \\
0.015 \\
0.013 \\
. .082 \\
0.146 \\
0.1645 \\
0.1535 \\
0.124 \\
0.857 \\
0.085 \\
6.023 \\
0.11 \\
0.44 \\
0.5 \\
0.63 \\
.48 \\
.48\end{array}$ & $\begin{array}{l}4.52 \\
4.52 \\
4.52 \\
4.52 \\
4.52 \\
4.52 \\
4.52 \\
4.52 \\
4.52 \\
4.52 \\
4.52 \\
4.52 \\
4.52 \\
4.62 \\
4.52 \\
4.52 \\
4.52 \\
4.52\end{array}$ & 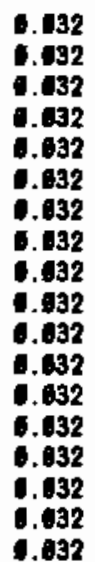 & $\begin{array}{r}0.1682599 \\
1.1510297 \\
0.4747017 \\
.4114691 \\
1.9823482 \\
4.6210138 \\
5.2085539 \\
4.6583944 \\
8.8246985 \\
1.8948943 \\
2.8573989 \\
0.7279679 \\
3.4915856 \\
13.8263423 \\
16.8253899 \\
16.7749123 \\
15.1923734 \\
15.1923734\end{array}$ & 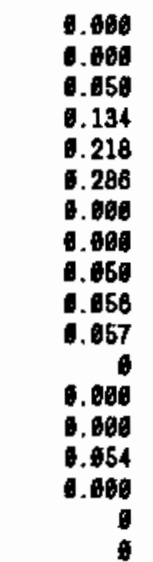 & $\begin{array}{r}1 \\
1 \\
1 \\
1 \\
1 \\
1 \\
5 \\
5 \\
5 \\
5 \\
5 \\
5 \\
10 \\
10 \\
10 \\
10 \\
10 \\
10\end{array}$ & $\begin{array}{r}0.134 \\
0.216 \\
0.286 \\
6 \\
.25 \\
.28 \\
.285 \\
6 \\
6.54 \\
6\end{array}$ & $\begin{array}{l}2.16 \\
2.16 \\
2.16 \\
2.18 \\
2.16 \\
2.16 \\
2.18 \\
2.16 \\
2.16 \\
2.18 \\
2.16 \\
2.16 \\
2.18 \\
2.18 \\
2.16 \\
2.16 \\
2.16 \\
2.18\end{array}$ & $\begin{array}{l}0.013 \\
0.013 \\
0.013 \\
0.013 \\
0.013 \\
0.013 \\
0.013 \\
0.013 \\
0.013 \\
0.013 \\
0.013 \\
0.013 \\
0.013 \\
.013 \\
0.013 \\
0.013 \\
0.013 \\
0.013\end{array}$ & 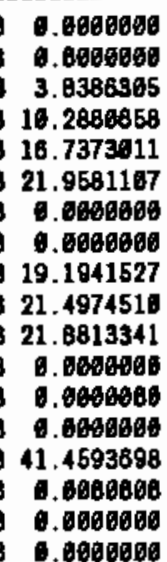 \\
\hline
\end{tabular}


CONTIMED. LCC-HOD TEST RESUTS

\begin{tabular}{|c|c|c|c|c|c|c|c|c|c|c|c|c|c|c|c|c|}
\hline IEST । & $\begin{array}{l}\text { ICP IDA } \\
\text { (Leach) }\end{array}$ & $\begin{array}{l}\text { ICP LAB } \\
\text { (Loach) }\end{array}$ & $\begin{array}{l}\text { ICP LAB } \\
\text { (GIass) }\end{array}$ & $\begin{array}{l}S A / V \\
(/ 0)\end{array}$ & $\begin{array}{l}\text { LEACH ICP } \\
\text { DATA }\end{array}$ & $\begin{array}{l}\text { DILUTION } \\
\text { FACTOR }\end{array}$ & $\ddot{c}$ & $\begin{array}{l}\text { Oxido itx } \\
\text { (glass ICP) }\end{array}$ & F & $\begin{array}{l}\text { Mormal ized } \\
\text { Conc. Ma }\end{array}$ & $\begin{array}{l}\text { LEACH ICP } \\
\text { DATA }\end{array}$ & $\begin{array}{l}\text { DILUTION } \\
\text { FACIOR }\end{array}$ & " & $\begin{array}{l}\text { oxide vit } \\
\text { (glass ICP) }\end{array}$ & $\mathbf{F}$ & $\begin{array}{l}\text { Nornalized } \\
\text { Conc. Si }\end{array}$ \\
\hline 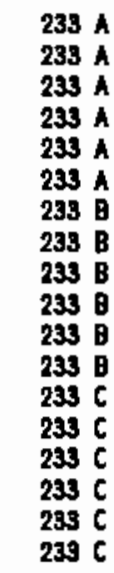 & $\begin{array}{l}A 7 \\
A 14 \\
A 21 \\
A 28 \\
A 96 \\
A 42 \\
87 \\
B 14 \\
821 \\
B 28 \\
895 \\
B 42 \\
C 7 \\
C 14 \\
C 21 \\
C 28 \\
C 35 \\
C 42\end{array}$ & $\begin{array}{l}292 \\
292 \\
292 \\
292 \\
292 \\
292 \\
294 \\
294 \\
294 \\
294 \\
294 \\
294 \\
296 \\
296 \\
296 \\
296 \\
296 \\
296\end{array}$ & 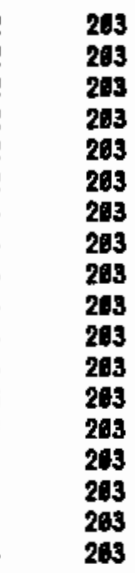 & 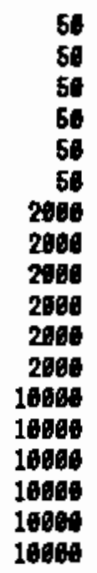 & $\begin{array}{l}0.064 \\
0.018 \\
0.111 \\
0.120 \\
0.177 \\
0.32 \\
6.107 \\
. .884 \\
0.147 \\
0.201 \\
0.271 \\
0.394 \\
0.683 \\
. .219 \\
. .387 \\
0.378 \\
1.434 \\
6.63\end{array}$ & $\begin{array}{r}1 \\
1 \\
1 \\
1 \\
1 \\
1 \\
5 \\
5 \\
6 \\
5 \\
6 \\
5 \\
10 \\
10 \\
10 \\
10 \\
10 \\
10\end{array}$ & $\begin{array}{r}1.864 \\
6.618 \\
0.111 \\
0.12 \\
6.177 \\
0.32 \\
0.636 \\
6.4 \\
0.735 \\
1 \\
1.365 \\
1.97 \\
0.83 \\
2.13 \\
3.87 \\
3.78 \\
4.34 \\
6.3\end{array}$ & $\begin{array}{l}1.74 \\
1.74 \\
1.74 \\
1.74 \\
1.74 \\
1.74 \\
1.74 \\
1.74 \\
1.74 \\
1.74 \\
1.74 \\
1.74 \\
1.74 \\
1.74 \\
1.74 \\
1.74 \\
1.74 \\
1.74\end{array}$ & 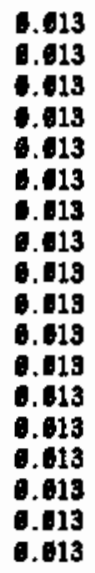 & 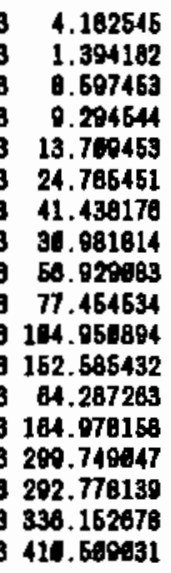 & $\begin{array}{r}0.165 \\
0.279 \\
0.799 \\
2.469 \\
5.29 \\
0.99 \\
0.392 \\
0.662 \\
1.310 \\
2.175 \\
2.92 \\
3.52 \\
0.925 \\
1.640 \\
2.029 \\
2.150 \\
2.52 \\
2.73\end{array}$ & $\begin{array}{r}1 \\
1 \\
1 \\
1 \\
1 \\
1 \\
5 \\
5 \\
5 \\
5 \\
5 \\
5 \\
10 \\
10 \\
10 \\
10 \\
10 \\
10\end{array}$ & $\begin{array}{r}0.165 \\
6.279 \\
6.799 \\
2.46 \\
5.29 \\
8.99 \\
1.68 \\
3.31 \\
8.55 \\
10.875 \\
14.6 \\
17.6 \\
9.25 \\
15.4 \\
20.2 \\
21.6 \\
25.2 \\
27.3\end{array}$ & $\begin{array}{l}52.4 \\
52.4 \\
52.4 \\
52.4 \\
52.4 \\
52.4 \\
52.4 \\
52.4 \\
52.4 \\
52.4 \\
52.4 \\
52.4 \\
52.4 \\
52.4 \\
52.4 \\
52.4 \\
52.4 \\
52.4\end{array}$ & $\begin{array}{l}0.245 \\
0.245 \\
0.246 \\
0.245 \\
.245 \\
.245 \\
.245 \\
.245 \\
.245 \\
0.245 \\
.245 \\
.245 \\
.245 \\
.245 \\
.245 \\
.245 \\
0.245 \\
0.245\end{array}$ & $\begin{array}{r}9.672832 \\
1.137698 \\
3.258139 \\
16.631317 \\
21.571410 \\
36.659164 \\
6.769160 \\
13.497423 \\
26.789462 \\
44.345762 \\
69.536466 \\
71.768774 \\
37.719384 \\
62.797677 \\
82.376979 \\
87.672882 \\
162.759838 \\
111.323156\end{array}$ \\
\hline TEST & $\begin{array}{l}\text { ICP IDS } \\
\text { (Leach) }\end{array}$ & $\begin{array}{l}\text { ICP LAB } \\
\text { (Leach) }\end{array}$ & $\begin{array}{l}\text { ICP LAB } \\
\text { (Olass) }\end{array}$ & $\begin{array}{l}\text { SA/N } \\
(/ D)\end{array}$ & $\begin{array}{c}\text { LEACH ICP } \\
\text { DATA }\end{array}$ & $\begin{array}{l}\text { DILUTION } \\
\text { FACTOR }\end{array}$ & $\ddot{c}$ & $\begin{array}{l}\text { Oxide its } \\
\text { (glass ICP) }\end{array}$ & $\ddot{F}$ & $\begin{array}{l}\text { Mornailized } \\
\text { Cone. Sr }\end{array}$ & $\begin{array}{l}\text { LEACH ICP } \\
\text { DATA }\end{array}$ & $\begin{array}{l}\text { DILUTION } \\
\text { FACTOR }\end{array}$ & $\ddot{c}$ & $\begin{array}{l}\text { Oxide vif } \\
\text { (gloss ICP) }\end{array}$ & $\ddot{F}$ & $\begin{array}{l}\text { Moraal ized } \\
\text { Conc. Cs }\end{array}$ \\
\hline 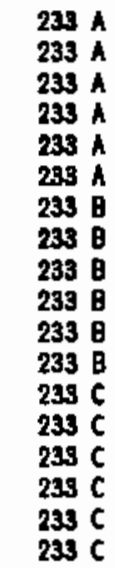 & $\begin{array}{l}A 7 \\
A 14 \\
A 21 \\
A 28 \\
A 35 \\
A 42 \\
87 \\
814 \\
821 \\
828 \\
835 \\
B 42 \\
C 7 \\
C 14 \\
C 21 \\
C 28 \\
C 35 \\
C 42\end{array}$ & $\begin{array}{l}292 \\
292 \\
292 \\
292 \\
292 \\
292 \\
294 \\
294 \\
294 \\
294 \\
294 \\
294 \\
296 \\
296 \\
296 \\
296 \\
296 \\
296\end{array}$ & $\begin{array}{l}293 \\
293 \\
293 \\
293 \\
293 \\
293 \\
293 \\
203 \\
263 \\
263 \\
203 \\
293 \\
293 \\
293 \\
293 \\
293 \\
293 \\
203\end{array}$ & 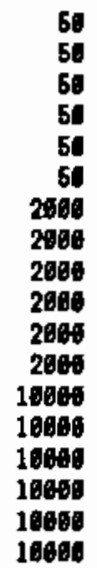 & 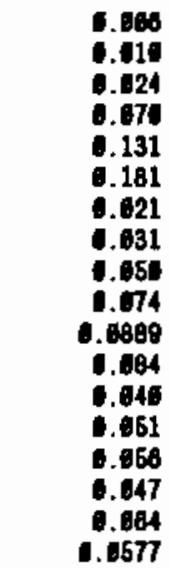 & $\begin{array}{r}1 \\
1 \\
1 \\
1 \\
1 \\
1 \\
5 \\
5 \\
5 \\
5 \\
5 \\
5 \\
10 \\
10 \\
10 \\
10 \\
10 \\
16\end{array}$ & 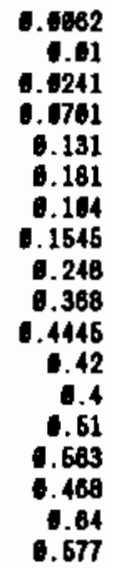 & $\begin{array}{l}1.39 \\
1.39 \\
1.39 \\
1.39 \\
1.39 \\
1.39 \\
1.39 \\
1.39 \\
1.39 \\
1.39 \\
1.39 \\
1.39 \\
1.39 \\
1.39 \\
1.39 \\
1.39 \\
1.39 \\
1.39\end{array}$ & $\begin{array}{l}0.012 \\
0.012 \\
0.012 \\
0.012 \\
0.012 \\
0.012 \\
0.012 \\
0.012 \\
0.012 \\
0.012 \\
0.012 \\
6.012 \\
0.012 \\
0.012 \\
0.012 \\
0.012 \\
0.012 \\
0.012\end{array}$ & 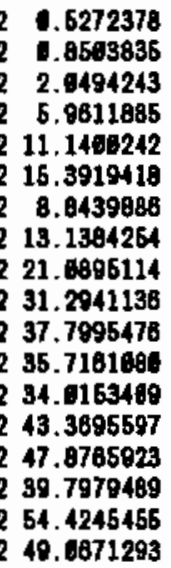 & 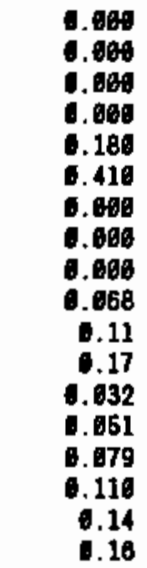 & $\begin{array}{r}1 \\
1 \\
1 \\
1 \\
1 \\
1 \\
1 \\
5 \\
5 \\
5 \\
5 \\
5 \\
5 \\
16 \\
10 \\
10 \\
10 \\
10 \\
10\end{array}$ & $\begin{array}{r}0 \\
0.18 \\
0.41 \\
0 \\
0 \\
0.34 \\
6.55 \\
0.85 \\
6.32 \\
0.51 \\
.79 \\
1.1 \\
1.4 \\
1.6\end{array}$ & $\begin{array}{l}0.36 \\
0.36 \\
0.38 \\
.36 \\
.38 \\
0.38 \\
0.38 \\
0.38 \\
0.38 \\
0.36 \\
.36 \\
0.36 \\
0.36 \\
6.36 \\
0.38 \\
0.36 \\
0.36 \\
.36\end{array}$ & 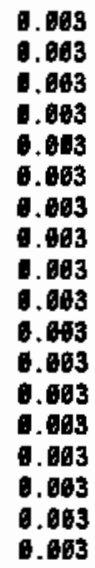 & 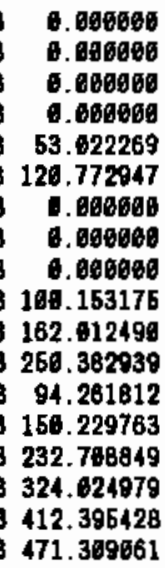 \\
\hline
\end{tabular}


CONTINUED. WCC-NOD TEST RESUTS

Sumnary of Noreilized Concentrat ion Rosult $\left(\mathrm{g} / \mathrm{m}^{3}\right)$ for $1 \mathrm{CC}$-nod Testing of ORRLCPilot-Scale. ISV Producta

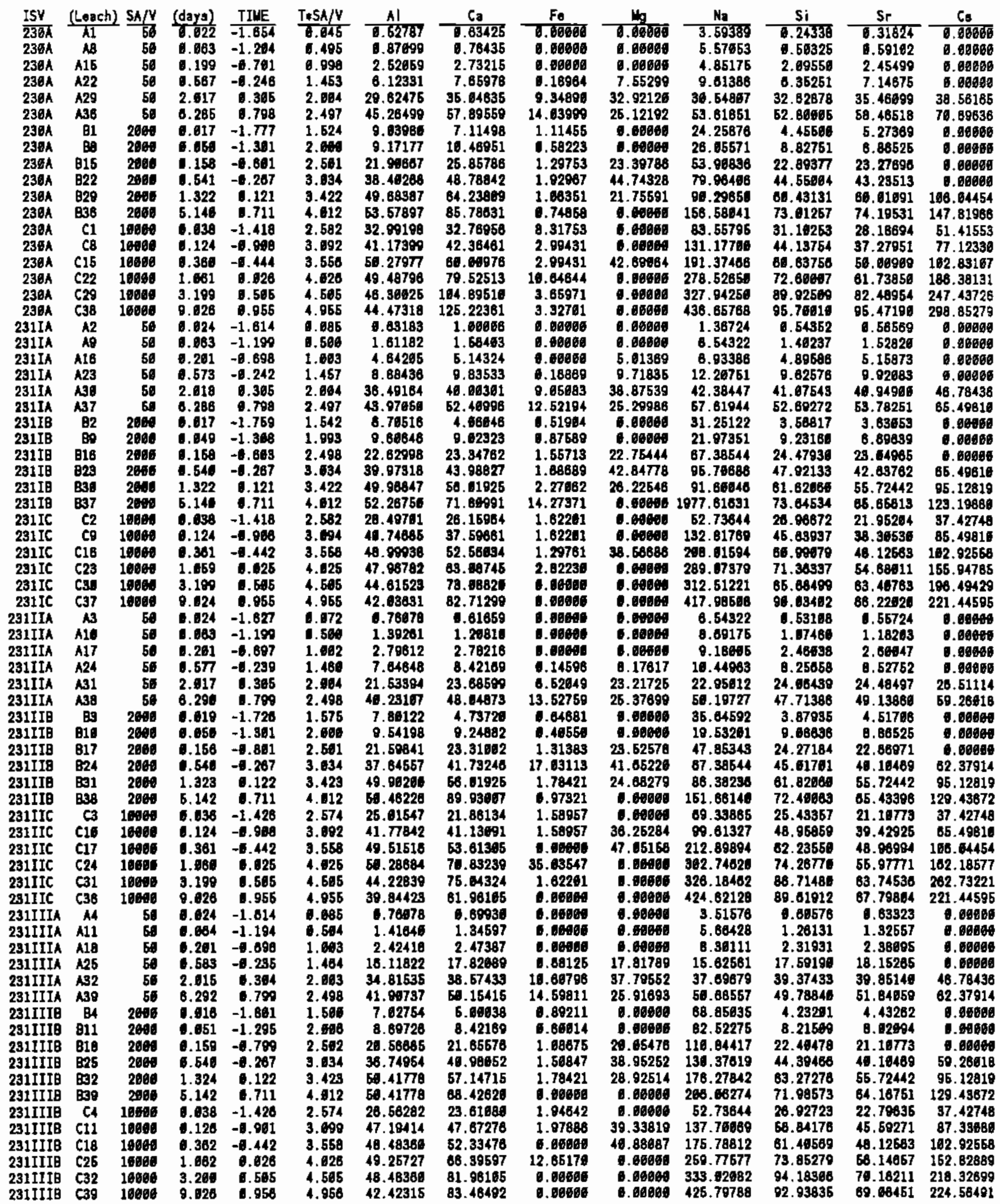


CONTINUED. UEC-LOD TEST RESUTS

CONJINUED. Suasary of Nornilized Concentration Result $\left(\mathrm{g} / \mathrm{n}^{3}\right.$ for WCC-Hod Tosting of ORNL Pilot-Seale ISV Products

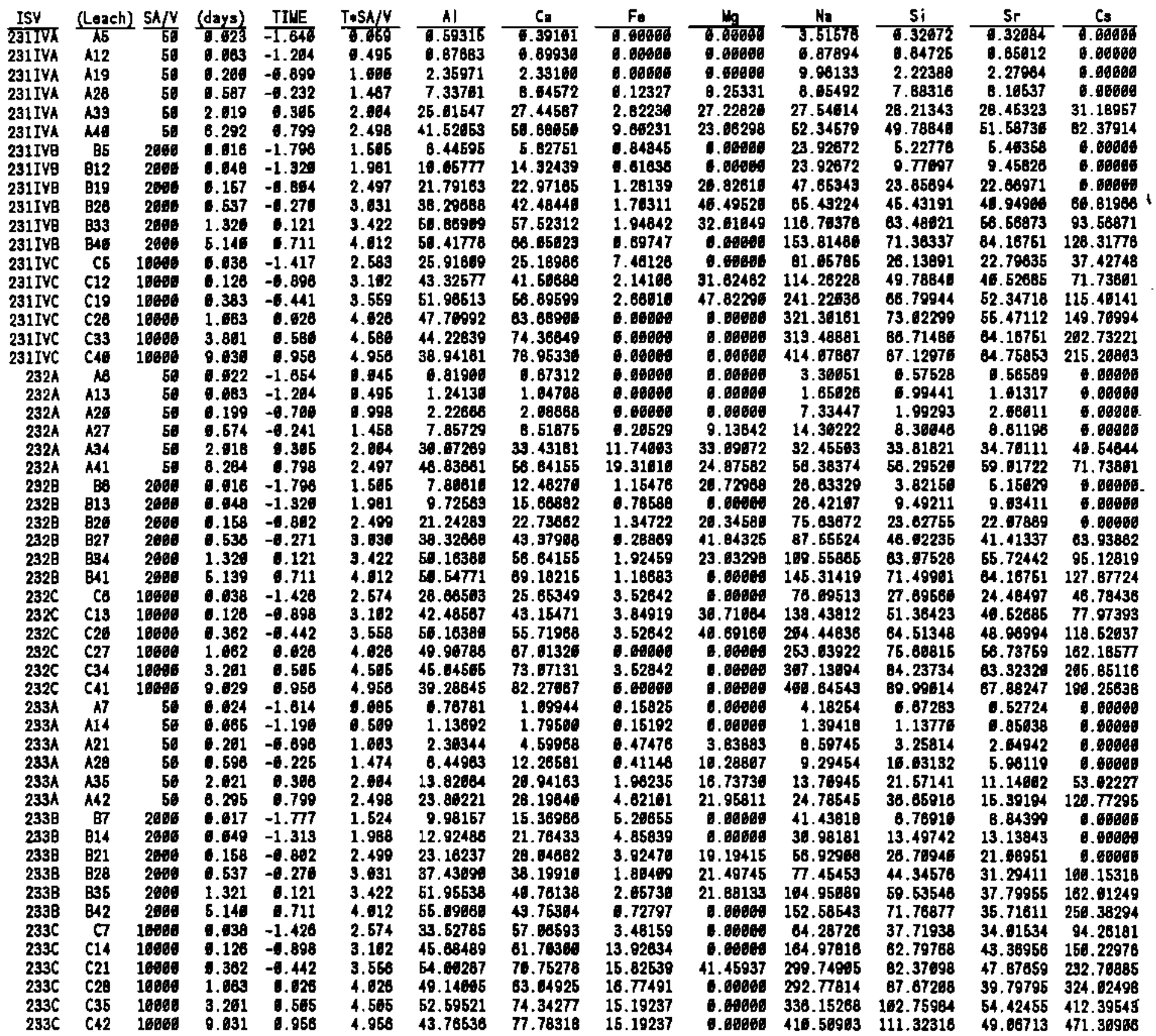


231 MOFULIZED COMGETTRATION VAUES $\left(9 / 0^{3}\right)$ : WEAM MO S.D. CNLCRATIONS

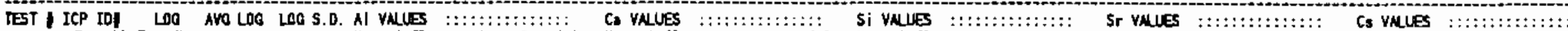

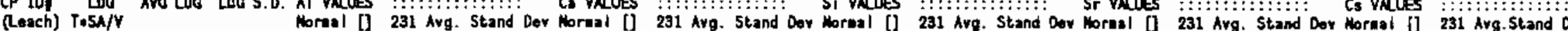

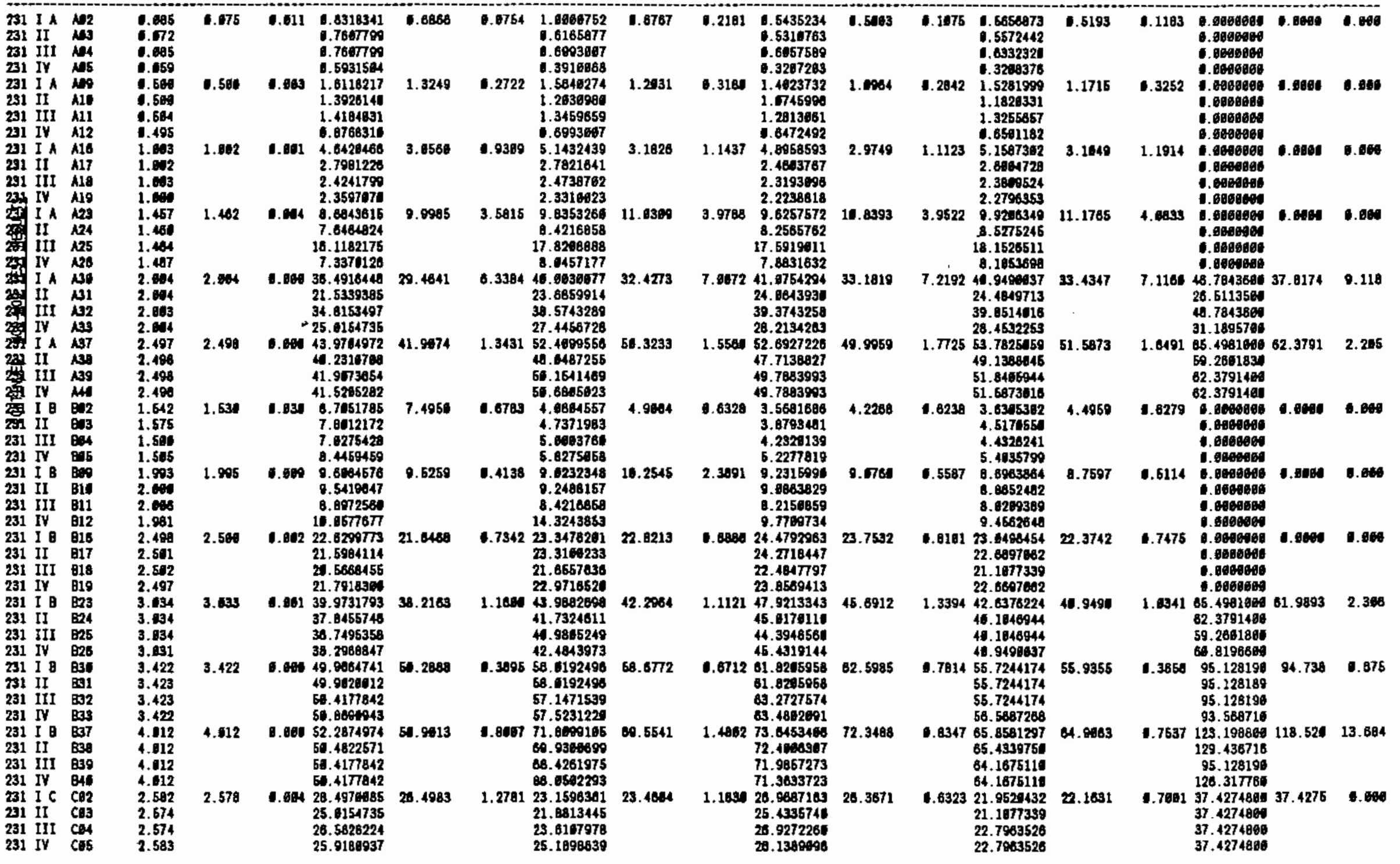




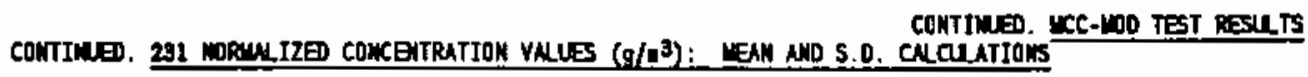

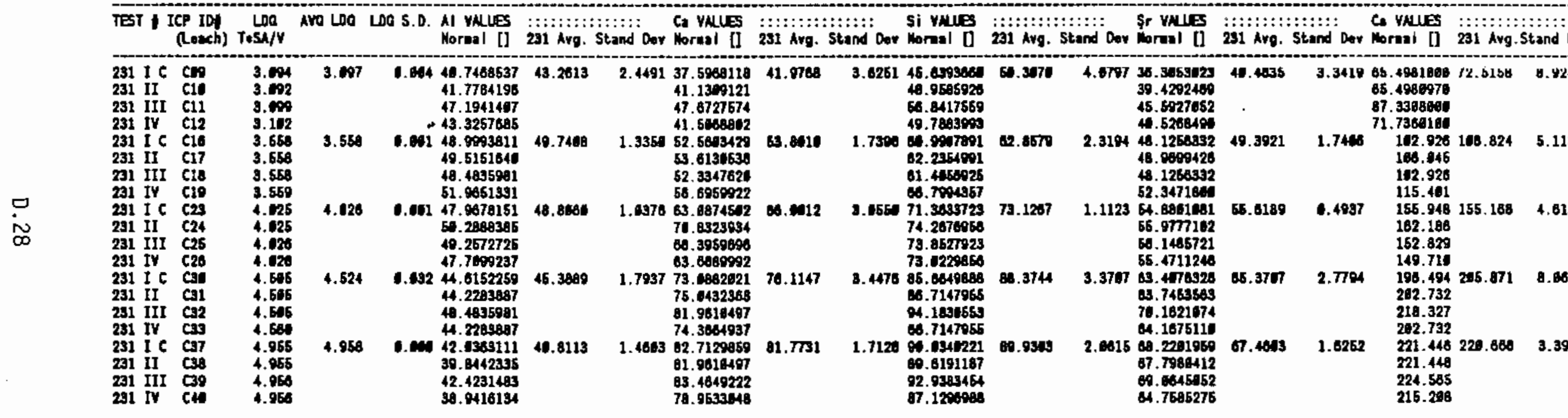


CONTINGE. WCC-MOD TEST RESULTS

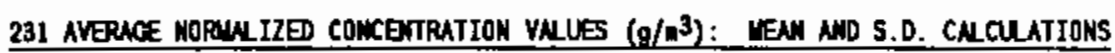

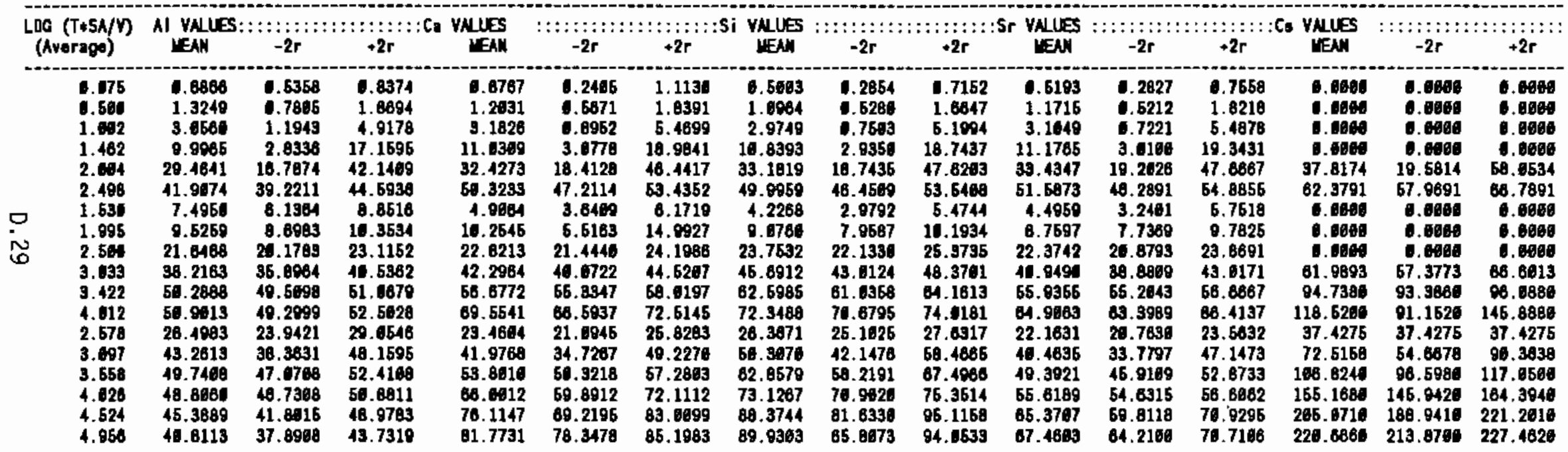





\section{APPENDIX E}

ANALYTICAL PROCEDURES 


\section{APPENDIX E}

\section{ANALYTICAL PROCEDURES}

\subsection{SAMPLE ANALYSIS OF ISV SOLUTIONS AND LEACHATES}

Since the samples contained significant amounts of solids, a measured aliquot of the solution aliquot was filtered through a tared 47-mm celTulose acetate membrane filter. The precipitate was air dried for at least 24 hours and reweighed. About $0.25 \mathrm{~g}$ of the dried solid was fused with $\mathrm{KOH}$ in a zircalloy-2 metal crucible. The fused solid was then leached with demineralized water, transferred into a $250-m L$ volumetric flask, acidified with hydrochloric acid, and diluted to volume with demineralized water. A 10-mL aliquot was pipetted into a $100-\mathrm{mL}$ volumetric flask and diluted to volume. This solution and the filtrate were analyzed on the ICP/AES for the listed ions.

Cesium in the filtrate was analyzed using the Graphite Furnace/Atomic Adsorption (GFAA) method. Since the fusion of the solid samples were acidified with $\mathrm{HCl}$ and since solutions containing significant amounts of $\mathrm{HCl}$ cannot be analyzed using the GFAA method, the fused samples were analyzed by flame AA method.

The results of the ions analyzed were reported as $\mathrm{mg} / \mathrm{L}$ in the filtrate and $\mathrm{mg} / \mathrm{L}$ in the precipitate, assuming that all the solids solubilized in the volume of the solution filtered. 

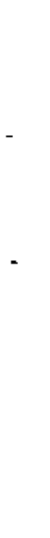


\section{OISTRIBUTION}

No. of

Copies

OFFSITE

10 DOE/Office of Scientific and Technical Information

5 DOE Office of Civilian

Radioactive Waste Management Forrestal Building Washington, DC 20585

ATTN: 1. H. Barrett, RW-33

C. R. Cooley, RH-40

S. H. Kale, RH-20

D. E. Shelor, RW-32

R. Stein, RW-23

3 DOE Office of Defense Waste \& Transportation Management GTN

Washington, DC 20545

ATTN: K. A. Chacey, DP -123

G. H. Daly, DP-124

T. B. Hindman, $\mathrm{DP}-12$

4 DOE Office of Remedial Action

$\&$ Waste Technology

GTN

Washington, OC 20545

ATTN: J. E. Baublitz, NE-20

J. A. Coleman, NE-24

T. W. Mc Intosh, NE-24

H. F. Walter, NE-24

A. T. Clark

Division of Fuel Material Safety

Nuclear Regulatory Commission

Washington, DC 20555

V. Stello

Office for the Executive

Director for Operations

Mail Station 6209

Nuclear Regulatory Commission

Washington, DC 20555
No. of

Copies

S. Meyers

Environmental Protection Agency

Office of Radiation Programs (ANR-458)

401 M Street S.W.

Washington, DC 20460

J. M. McGough

DOE ATbuquerque Operations Office

P.0. Box 5400

Albuquerque, NM 87185

P. G. Hagan

Joint Integration Office

Carlmont Executive 1

4308 Carlisle N.E.

Suite 101

Albuquerque, NM 87107

E. Maestas

DOE West Valley Project

P.0. Box 191

West Valley, NY 14171

3 OOE Idaho Operations Office

550 Second Street

Idaho Falls, I0 83401

ATTN: S. T. Hinschberger

J. P. Hamric

C. R. Enos

F. T. Fong

DOE San Francisco Operations

1333 Broadway

0akland, CA 94612

2 OOE Oak Ridge Operations Office P.0. Box E

Oak Ridge, TN 37830

ATTN: M. R. Jugan

R. A. Jump 
No. of

Copies

W. T. Goldston

DOE Savannah River Operations Office

P.0. Box A

Aiken, SC 29801

M. J. Steindler

Argonne National Laboratory

9700 South Cass Avenue

Argonne, IL 60439

C. 5. Abrams

Argonne National Laboratory

P.0. Box 2528

Idaho Falls, ID 83401

3 Battelle Memorial Institute

Project Management Division

$505 \mathrm{King}$ Avenue

Columbus, $\mathrm{OH} 43201$

ATTN: W. A. Carbeiner

R. A. Nathan

Technical Library

L. D. Ramspott

Lawrence Livermore Nationa] Laboratory

University of California

P.0. Box 808

Livermore, CA 94550

D. T. Oakley, MS 619

Los Alamos Scientific Laboratory

P.0. Box 1663

Los Alamos, NM 87544

16 Oak Ridge National Laboratory

P.0. Box Y

Oak Ridge, TN 37830

ATTN: L. D. Bates

W. D. Burch

G. K. Jacobs

R. T. Jubin

L. J. Mezga

T. A. Row

B. P. Spalding (20)
No. of

Copies

2 Sandia Laboratories

P.0. Box 5800

Albuquerque, NM 87185

ATTN: R. W. Lynch

Technical Library

J. R. Berreth

Westinghouse Idaho Nuclear

Co. . Inc.

P.0. $80 \times 4000$

Idaho Falls, ID 83401

6 E. I. du Pont de Nemours Company

Savannah River Laboratory

Aiken, SC 29801

ATTN: R. G. Baxter

M. D. Boersma

J. G. Glasscock

J. R. Knight

M. J. Plodinec

C. T. Randall

A. D. Rodgers

Mail Stop 2411

EG\&G Idaho

P.0. Box 1625

Idaho Falls, ID 83415

R. Shaw

Electric Power Research Institute

3412 Hillview Avenue

P.0. Box 10412

Palo Alto, CA 94303

4 West Valley Nuclear Services Company

P.0. Box 191

West Valley, NY 14171

ATTN: J. C. Cwynar

5. J. Marchette

J. M. Pope

R. A. Thomas 
No. of

Copies

J. L. White, Chaiman

Energy Research \& Development Authority

Empire State Plaza

Albany, NY 12223

\section{ONSITE}

7 DOE Richland Operations Office

R. H. Brown

C. E. Collantes

M. J. Furman

R. E. Gerton

P. E. Lamont

M. W. Shupe

J. J. Sutey

8 Westinghouse Hanford Company

J. M. Henderson

R. E. Lerch

H. E. McGuire

J. L. Scott

D. A. Turner

D. D. Wodrich

R. D. Wojtasek

B. A. Wolfe
No. of

Copies

44 Pacific Northwest Laboratory

W. W. Ballard, Jr.

S. 0. Bates (5)

W. F. Bonner

K. A. Borgeson

D. J. Bradley

R. A. Brouns

J. L. Buelt

H. C. Burkholder

J. G. Carter (10)

T. T. Claudson

M. R. Elmore

F. T. Hara

W. 0 . Heath

D. E. Knowlton

S. S. Koegler

M. R. Kreiter/J. E. Mendel

J. L. McEl roy

K. H. Oma

J. M. Perez, Jr.

M. E. Peterson

J. A. Powell

M. A. H. Reimus

S. C. Slate

C. L. Timenerman

Publishing Coordination (2)

Technical Report Files (5) 
